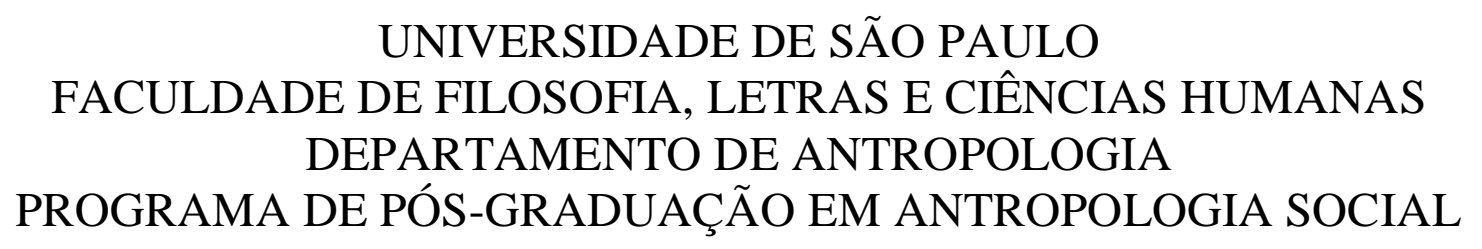

DANIEL DE LUCCA REIS COSTA

A RUA EM MOVIMENTO

experiências urbanas e jogos sociais em torno da população de rua 


\author{
UNIVERSIDADE DE SÃO PAULO \\ FACULDADE DE FILOSOFIA, LETRAS E CIÊNCIAS HUMANAS \\ DEPARTAMENTO DE ANTROPOLOGIA \\ PROGRAMA DE PÓS-GRADUAÇÃO EM ANTROPOLOGIA SOCIAL
}

\title{
A RUA EM MOVIMENTO \\ experiências urbanas e jogos sociais em torno da população de rua
}

Daniel De Lucca Reis Costa

Dissertação apresentada ao Programa de Pós-Graduação em Antropologia Social do Departamento de Antropologia da Faculdade de Filosofia, Letras e Ciências Humanas da Universidade de São Paulo, para obtenção do título de Mestre em Antropologia Social.

Orientador: $\operatorname{Prof}^{\mathrm{o}}$ Dr. Heitor Frúgoli Jr. 


\section{Folha de Aprovação}

\section{Daniel De Lucca Reis Costa}

A rua em movimento - experiências urbanas e jogos sociais em torno da população de rua

Tese apresentada à Faculdade de Filosofia, Letras e Ciências Humanas da Universidade de São Paulo para obtenção do título de Mestre em Antropologia Social.

Área de Concentração: Antropologia Urbana.

Aprovado em:

Banca Examinadora

Prof. Dr.

Instituição: Assinatura:

Prof. Dr.

Instituição: Assinatura:

Prof. Dr.

Instituição: Assinatura: 


\section{RESUMO}

DE LUCCA, Daniel. A rua em movimento - experiências urbanas e jogos sociais em torno da população de rua. 241 f. Dissertação (Mestrado) - Faculdade de Filosofia, Letras e Ciências Humanas da Universidade de São Paulo, São Paulo, 2007.

Partindo da hipótese de que a população de rua, tal como é concebida hoje, não existiu desde sempre, o objetivo deste trabalho é interrogar parcialmente os jogos de relações que definem este fenômeno enquanto uma questão social. Isto através de três perspectivas fundamentais: sua constituição histórica, sua contestação política e sua regulação institucional. Para tal, utilizo-me do conceito foucaultiano de dispositivo, de modo a tratar esta realidade como efeito de correlações dinâmicas entre agentes, discursos e instituições, estrategicamente situadas no centro da cidade de São Paulo. No primeiro capítulo, busco, através de trajetórias entrecruzadas de atores diretamente envolvidos com o tema, traçar a trama de uma história capaz de expor o nascimento da população de rua como questão social, bem como delinear seu campo de aparição. No segundo capítulo, através de uma cadeia de cinco mobilizações sociais, apresento rituais políticos capazes de exporem as dimensões públicas e conflituosas do fenômeno, assim como o campo de forças em que este se situa, dando especial destaque para os modos no qual o Movimento Nacional da População de Rua (MNPR) elabora um discurso sobre si frente a outras alteridades políticas. No terceiro e último capítulo, apresento a população de rua como um problema de gestão e segurança, descrevendo alguns componentes da rede de atendimento e proteção deste contingente, destacando a importância do albergue nesta composição, e problematizando etnograficamente os usos destes equipamentos institucionais. Entende-se, neste trabalho, que a definição do fenômeno população de rua é um objeto provisório, foco de múltiplos agenciamentos urbanos, e cujo contorno constitui-se como o alvo privilegiado dos questionamentos que o presente estudo busca interrogar.

Palavras-chave: população de rua, dispositivo, movimentos sociais, albergue, centro de São Paulo. 


\begin{abstract}
DE LUCCA, Daniel. The street in movement - urban experiences and social configurations among the homeless population. $241 \mathrm{f}$. Dissertação (Mestrado) - Faculdade de Filosofia, Letras e Ciências Humanas da Universidade de São Paulo, São Paulo, 2007.

This study works from the hypothesis that the homeless population (população de rua) of São Paulo, today considered a problem in terms of its growth and control, has not always been considered in these terms. The study seeks, therefore, to interrogate the sets of relations that define this phenomenon as a social question. This approach is developed through three central perspectives: the historical formation of this population, the political conflicts that surround it and its institutional regulation. To this end, the Foucaultian concept of dispositif is considered as a way of treating this reality as the consequence of dynamic correlations between agents, discourses and institutions, strategically situated in the centre of the city of São Paulo. In chapter one, the history of the appearance of the homeless population as a social question is explored through a series of intertwined trajectories of individuals and organizations directly involved with this issue. In chapter 2, through the analysis of a sequence of five political protests, the study explores the ways in which political rituals expose the public and conflictive dimensions of this phenomenon, as well as the political context in which it is situated, with particular emphasis on the ways in which the National Movement of the Homeless Population (Movimento Nacional da População de Rua) elaborates its discourse in dialogue with other political entities. In the third and last chapter of this study, the homeless population is considered as a management and security problem. This chapter describes some of the components of the network of assistance and protection services offered to the homeless, highlighting among these the importance of the hostel, and exploring, from an ethnographic perspective, the uses of these institutional services. This study considers the definition of the phenomenon of homelessness as a provisional object, the focus of a multitude of urban agencies whose configurations represent the field of reference that this study seeks to explore.
\end{abstract}

Key words: homeless population, dispositif, social movements, hostel, centre of São Paulo. 
À Casa da Aclimação, com suas lembranças, conversas e cheiros culinários que, arrebatando-me em torvelinhos de sensações, colocaram-me a caminhar. 


\section{Sumário}

\section{Agradecimentos}

1. Introdução........................................................................................................................10

1.1. Inserção no campo e o percurso da pesquisa................................................................10

1.2. Hipótese e campo de problematização....................................................................18

1.3. Articulação conceitual...........................................................................................21

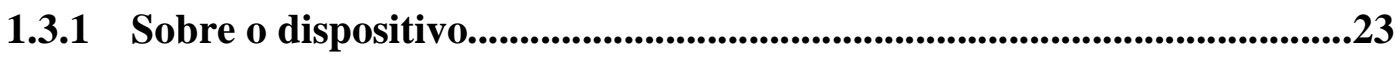

1.3.2 Experiência urbana e conexões parciais................................................27

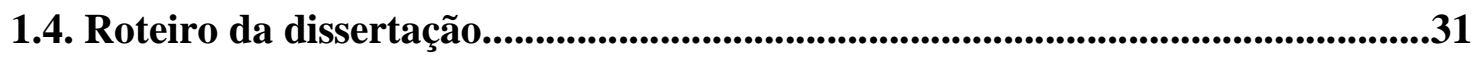

2. Capítulo I: Tecendo a trama de uma história..............................................34

2.1. Costurando trajetórias com fios da experiência...................................................34

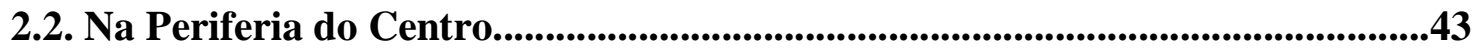

2.2.1 Irmã Fortunata..................................................................................................................45

2.2.2. Irmã Regina................................................................................................51

2.2.3. Luiz Kohara......................................................................................................58

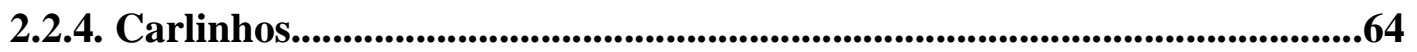

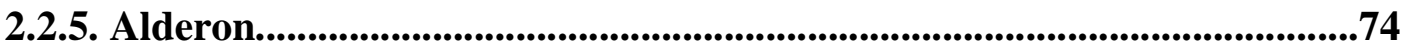

2.2.6. Pastora Mabel.................................................................................................................89

2.2.7. Padre Júlio.........................................................................................................................95

2.2.8. Anderson.........................................................................................................106

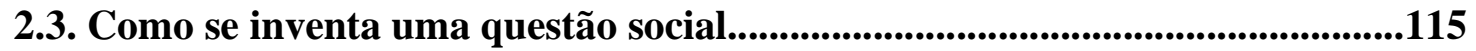

3. Capítulo II: Política de rua......................................................................126

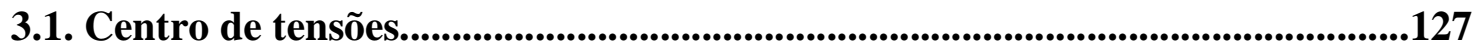

3.1.1. Novos atores em movimento..................................................................137

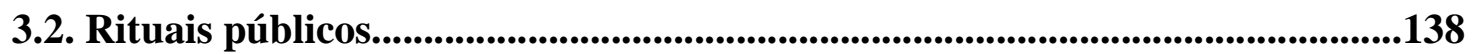

3.2.1. Prelúdio.................................................................................................................142

3.2.2. Seminário de Políticas Públicas - 6/6/2005..............................................143

3.2.3. Ato contra a lei $-7 / 6 / 200$........................................................................................148

3.2.4. Ato contra o Massacre da População de Rua - 19/8/200............................153

3.2.5. Dia de Luta do Povo da Rua - 19/5/200.......................................................158 
3.2.6. Abaixo a Repressão aos catadores - 20/6/2006........................................163

3.3. Como se luta num campo de conflitos...............................................................168

3.3.1. Antagonismo e fusão de reivindicações...............................................169

3.3.2. O discurso da população de rua frente suas alteridades fronteiriças..173

4. Capítulo III: Rede de proteção, albergue e seus usos..........................182

4.1. Rede de atendimento e proteção social.........................................................182

4.2. Experiência albergal...........................................................................................190

4.2.1. Contexto urbano e etnográfico..............................................................192

4.2.2. A entrada e o trabalho da portaria........................................................197

4.2.3. As regras, $\mathrm{o}$ espaço albergal e $\mathrm{o}$ achatamento das diferenças.................202

4.2.4. Escalonamento, relações de poder e lógicas da rede................................210

4.3. Como se gere uma população.........................................................................220

5. Considerações finais.....................................................................228

6. Referências bibliográficas..................................................................234

6.1. Bibliografia geral...............................................................................................................2234

6.2. Bibliografia específica.....................................................................................239 


\section{Agradecimentos}

À FAPESP, pelo integral apoio financeiro ao trabalho.

Ao meu orientador, Prof. Dr. Heitor Frúgoli Jr., pelo apoio, confiança, dedicação e estímulo constante.

Às pessoas que conheci no universo da rua, cuja amizade, conversa e troca, me permitiram apreender uma sabedoria inestimável e que, indiscutivelmente, fizeram de mim uma pessoa melhor: Agnaldo, Eduardo, Passos, Manuel, Donizete, Paulinho, Ciganinha e muitos outros. Sou especialmente grato a Miguel, vida que não brilha mais entre nós, mas que no começo de minha inserção neste mundo, socorreu-me de uma perigosa e complicada situação. Logo após minha entrada no programa de pós-graduação, Miguel "morreu de rua". Sua ida repentina deixou-me na boca a palavra muda: obrigado. A ele sou mais grato que todos por tornar possível este trabalho.

Aos profissionais, assistentes sociais e educadores, que se encontram em meio a uma turbulenta e difícil luta diária. Pela atenção prestada, agradeço principalmente ao albergue que me acolheu.

Ao Movimento Nacional de Luta em Defesa dos Direitos da População em Situação de Rua: Anderson Lopes, Carlos Henrique Aquino, Sebastião Nicomendes e seus outros integrantes. Pela abertura ao diálogo, à participação, mas também à possibilidade de aprendizado conjunto.

Ao Movimento Nacional dos Catadores de Materiais Recicláveis, em especial Carlão, Eduardo, Roberto, mas também a vários outros catadores que conheci e com quem aprendi diante de suas diversas e impressionantes histórias de vida e luta.

Àqueles que me foram tão gentis. Pela abertura e atenção às insistentes perguntas, muito obrigado Padre Júlio Lancellotti, Luiz Kohara, Alderon Pereira da Costa, Mabel Andrade Garcia e Fortunata Novaes Gominho.

Aos integrantes da Organização do Auxílio Fraterno, pelo imenso apoio, troca e atenção: Regina Maria Manoel, Ivete de Jesus, Priscilla Argondizo, Juliana Cavalcanti e André.

Aos que contribuíram inestimavelmente para as reflexões aqui presentes, nossa interlocução foi de fundamental importância: Antonieta Vieira, Cecília Toseli e Nena de Souza.

Aos integrantes do Fórum de Debates sobre População em Situação de Rua, do qual orgulhosamente faço parte. Que nosso diálogo continue por muito tempo. Um especial obrigado a Ricardo Mattos, Luiz, Zeca e Cleisa Maffei Rosa. Nossa interlocução foi essencial para a consolidação deste estudo.

À Mitiko, por suas estimulantes observações sobre a experiência albergal, e Marie-Ghislaine Stoffels, pela atenção prestada.

A Walter Varanda e Prof. Dr. Rubens Adorno, pelas instigantes conversas, trocas de informações e a abertura para um pensar mais salutar sobre a experiência de rua. 
Aos meus inestimáveis colegas do Grupo de Estudos de Antropologia da Cidade (GEAC), pelas estimulantes discussões teóricas e confrontações empíricas, pelas incessantes interrogações lançadas à cidade e que ajudaram muito a fazer este trabalho andar. Ao Carlos Aquino, Caroline Hilário Macedo, Enrico Spaggiari e Isadora. À Jessie Sklair Corrêa, figura única, você mostrou-se uma ótima antropóloga, vizinha e amiga.

Ao Prof. Dr. Julio Simões, com quem aprendi muito sobre antropologia. Obrigado pela atenta leitura do trabalho. À Prof ${ }^{a}$. Dra. Cibele Rizek, cuja leitura da qualificação e comentários tecidos foram importantes para a reelaboração deste trabalho.

Aos professores que talvez, mesmo sem o saber, tiveram grande influência na construção deste trabalho e também em minha formação como cientista social: Ronaldo de Almeida, Amélia Damiani, Vera Telles, Fernando Pinheiro, Luis Jackson e Rosemary Segurado.

Aos meus parceiros e interlocutores do Centro Brasileiro de Análise e Planejamento: Tiarajú D'Andrea, Maurício Fiori, Edlaine Campos e Eva Scheliga. As diferentes perspectivas que vocês suscitaram, no decorrer de nosso diálogo, permitiram a realização deste trabalho.

A meus queridos amigos latino-americanos "basurólogos": Lucia Fernandes e Felix. Obrigado pelas conversas, estadias transnacionais e o constante fomento à imaginação política.

Aos colegas da pós-graduação, que se mostraram verdadeiros interlocutores acadêmicos. À possibilidade de reflexão teórica no Grupo de Estudos Filosóficos de Foucault e Deleuze. A todos meus colegas da Fundação Escola de Sociologia e Política e, também, àqueles do curso de Geografia da Universidade de São Paulo.

À eterna Fantástica Fábrica de Groove, cujos amigos, sensações, melodias e emoções foram e são muito importantes para mim: Fred Menino, Igor Carletto, Marilhão e outros fantásticos. Também me acompanharam nesta jornada, principalmente nos muitos momentos de leitura e produção de texto, John Coltrane e Thelonius Monk.

Muitos amigos envolveram-se na produção desta dissertação, por falta de espaço não poderei incluir todos. Cito apenas aquele círculo mais imediato de convívio: Luís Eduardo, Karol, Renata, e meus queridos vizinhos Jorge e Luciana. À querida Gabizilda, cuja ausência se faz intensamente presente. Conversas e mais conversas, comidas, bebidas, sorrisos e felicidades. Também meu primo, Carlos Gustavo De Lucca, que nos últimos momentos, de mais "pressão", mostrou-se um belo companheiro.

À minha amada família: meu querido pai Osório e Dalvinha; Dona Elza, cuja lucidez insólita, dos seus quase noventa anos, irradia e multiplica o amor de todos; estimado amigo, professor e tio, Walter De Lucca, cujas conversas, leituras e aventuras produziram grande efeito em minha formação. À Elô, pelo carinho e cuidado. Á Kika, Ike e Luis Antônio Leite, obrigado por poder contar com vocês. À minha mãe querida, Edy, cuja atenção e paciência tornaram possível a feitura deste trabalho.

Ao meu lindo amor, Lígia, por me ensinar a lidar com enredos, entrever as figuras que contornam e dão vida à própria vida. Sem você este trabalho seria impossível, e também sem você as coisas não seriam tão coloridas. Espero que continuemos a brincar de perto e juntos estes tão deliciosos jogos de linguagens. 
"A cidade é mais do que um lugar no espaço, é um drama no tempo."

Patrick Geddes

"O que se encontra no começo histórico das coisas não é a identidade ainda preservada da origem - é a discórdia entre as coisas, o disparate. A história ensina também a rir das solenidades de origem."

Michel Foucault 


\section{Introdução}

Sabe-se que todo conhecimento produzido é resultado de um jogo de compromissos, posturas e idéias. Ele aparece como efeito do choque e afrontamento de experiências heterogêneas, como "uma centelha entre duas espadas", que, ao lançar feixes de luz sobre horizontes, esclarece certos contornos e, ao mesmo tempo, sombreia outras paisagens. E neste sentido, todo conhecimento é sempre um desconhecimento (Foucault, 2002:17). Por isso mesmo, desejo nesta introdução compartilhar com o leitor alguns dos elementos que participaram desta pesquisa e, portanto, do jogo de luz e sombras que inevitavelmente a envolve. Apresentarei inicialmente meu percurso de investigação no tema e a maneira como construí meu campo de problematização. Posteriormente discutirei os referenciais teóricos e metodológicos utilizados. Por último será apresentada a estrutura da dissertação e o conteúdo de seus capítulos.

\subsection{Inserção no campo e o percurso da pesquisa}

Meu primeiro contato reflexivo com o universo pesquisado se deu em 2001, em meu segundo ano de graduação, quando num pequeno trabalho de sociologia, tentei pensar no morador de rua como um outsider nos termos colocados por Nobert Elias (Elias; Scotson, 2000). Na época tinha contato com este público através de familiares próximos a uma ONG, e inevitavelmente alguns comentários sobre o trabalho com este público chegavam até mim por meio dessas pessoas. Particularmente a representação e apresentação do morador de rua como um excluído social era algo que me causava certo incômodo. Como morei boa parte da minha vida no centro de São Paulo e, de uma maneira ou outra, sempre presenciei pessoas circulando, dormindo e comendo no espaço público da cidade, os habitantes das ruas nunca me pareceram serem figuras que ficassem realmente "por fora" das coisas. Assim, comecei a imaginar se seria possível tratar sociologicamente esta figura não mais através de uma exterioridade excludente, mas no interior de uma configuração relacional que, na época, não era nem um pouco clara para mim.

Posteriormente, em 2003, quando fiz meu trabalho de conclusão de curso, também retomei o tema. Só que aí resolvi desenvolver melhor o trabalho de campo que já havia iniciado em 2001. Durante o período de quase um ano trabalhei como voluntário, uma tarde por semana, na Associação Minha Rua Minha Casa (AMRMC), localizada debaixo de um 
viaduto na Baixada do Glicério, na região central da cidade ${ }^{1}$. Nesta instituição, além da conversa e da escuta, escrevi cartas, preparei, servi e comi sopa junto com os usuários, toquei violão e, também, monitorei estágios de pelo menos dois grupos de estudantes do segundo grau oriundos de um colégio particular. Apesar de em minha monografia de graduação não ter aproveitado os dados de campo, foi este contato etnográfico com a questão que me abriu uma multidão de interrogações e, principalmente, angústias. O público que freqüentava aquele espaço, a despeito de ser extremamente heterogêneo, carregava consigo fortes marcas de distinção não só de classe, mas também estigmas corporais e uma ampla gama de sinais que anunciavam a existência de um mundo, senão subterrâneo, ao menos enigmático e extremamente paradoxal para mim. Mundo portador de elementos que me faziam pensar colocando em movimento todas aquelas categorias lógicas e sociológicas que recentemente havia descoberto na graduação.

Também foi nesta experiência como voluntário que comecei a me dar conta da maior complexidade da questão que, então, me propunha a entender e intervir. E digo complexidade não só pelas precárias, e até mesmo desesperadoras, condições de saúde e vida em que certos usuários do espaço apresentavam. A angústia e complicação das coisas sempre surgiam através da insistente e prática pergunta: “o que fazer?”. Questão aparentemente boba, mas que a todo instante é posta no jogo das relações com a rua, um universo marcado justamente pelo movimento, ambigüidade e incerteza. Contudo, esta questão prática não se restringia unicamente à "clientela" dos serviços, ela era efetuada para toda sorte de relações ali presentes. Dirigia-se ao voluntário que por acaso se indispunha com um usuário; ao policial que porventura agredia alguém na frente, ou até mesmo dentro da instituição; aos funcionários novos que desconheciam algumas regras internas; à falta de verba, alimento, água ou luz decorrente de algum atrito ou um não esclarecido engano com os poderes públicos; às brigas e pelejas entre os moradores de rua que dormiam na frente da instituição e não se utilizavam dela, e àqueles que dela se utilizavam. Esta questão também se direcionava para o jovemvoluntário-pesquisador-bem-disposto que achava aquilo tudo muito estranho, e até mesmo errado, só que infortunadamente não tinha nada melhor a propor.

Neste aprendizado fui conhecendo melhor algumas pessoas, referências e circuitos de pertencimentos institucionais e não institucionais. Fui me dando conta da existência de uma gramática de relações mais ampla capaz de pôr em comunicação e circulação desde a

\footnotetext{
${ }^{1}$ As atividades desta associação e sua história serão melhor apresentadas no capítulo 1 da dissertação. Mas por enquanto vale dizer que a AMRMC é um dos mais antigos espaços de referência no trato com a população de rua adulta na cidade de São Paulo.
} 
linguagem mais informal e localizada da rua, carregada de gírias, sotaques e "leis" próprias, até um léxico mais formal próprio à arena pública e política (ou melhor, a um tipo específico de arena pública que no decorrer do trabalho espero apresentá-la em ação). Ao término de minha monografia, recebi um convite para apresentá-la no Fórum de Debates sobre População em Situação de Rua, do qual participo até os dias de hoje ${ }^{2}$.

Em 2005, quando entrei no mestrado, meu projeto inicial de pesquisa tinha por objetivo descrever e interpretar os usos e sentidos atribuídos pelos catadores moradores de rua ao lixo urbano e aos lugares públicos do centro paulistano. A proposta era identificar como estas pessoas significam e utilizam o meio e os recursos com os quais vivem diariamente. Entretanto, as questões levantadas pela pesquisa foram deslocando-se paulatinamente. A experiência do trabalho de campo, com toda sua riqueza e surpresa, imprimiu à investigação a necessidade de alterações analíticas e de foco, deslocando-se dos moradores de rua em si, para as intrincadas mediações que os atravessam e os definem.

Ao ir mais a campo, ouvir narrativas e histórias de rua, presenciar manifestações públicas, escutar técnicos e profissionais da área, participar de seminários e congressos vinculados ao tema, ler artigos e matérias de jornais, aprofundar-me na bibliografia especializada, visitar albergues e cooperativas, compartilhar de discussões coletivas no Fórum de Debate sobre População em Situação de Rua e embrenhar-me nas controvérsias políticas e éticas, ou seja, ao dar-me conta da enorme multiplicidade de agenciamentos, visões, posturas e proposições envolvidas com o fenômeno "morador de rua", tornou-se praticamente impossível silenciar sobre a pluralidade de vozes que irradiavam de toda esta mobilização coletiva.

As questões que foram sendo colocadas implicavam, portanto, numa contrapartida da pergunta inicial. Não mais unicamente "como as múltiplas experiências de rua se relacionam com o urbano", mas também, "como a multiplicidade do urbano se relaciona com a experiência das ruas". Desta maneira, comecei a explorar a possibilidade de a interrogação

\footnotetext{
${ }^{2}$ O Fórum de Debates sobre População em Situação de Rua, apesar de inicialmente ter sido criado com o propósito de incentivar a pesquisa, hoje se configura como um espaço público "intermediário", onde participam não só estudantes; mas terapeutas ocupacionais, assistentes sociais, educadores, psicólogos, médicos e outros profissionais da área; também usuários de equipamentos, ex-moradores de rua, vendedores de revistas de rua, lideranças do MNPR, além de outras formas de representação desta população. Mesmo não possuindo um caráter propositivo, este Fórum apresenta-se publicamente como um espaço de formação, apoio e articulação destas três categorias de atores: pesquisadores, profissionais da área e população de rua. Este Fórum nasceu em 2001, sob a coordenação de Cleisa Maffei Rosa, quando as reuniões ocorriam no Centro Estudos sobre População de Rua, que durante seu breve tempo de vida, localizou-se no Projeto Boracéia, no Bairro da Barra Funda. Tal era a finalidade do fórum, que seu nome inicial era Fórum de Estudos sobre População de Rua e só posteriormente transformou-se em Fórum de Debates, com uma significativa diversificação de seus participantes, bem um deslocamento de seus objetivos iniciais e de suas relações institucionais com o comentado Projeto.
} 
inicial ser intercambiada por seu outro, e neste movimento percebi que esta troca temporária de referências permitiria abrir outras sendas investigativas, ao jogar luz sobre novos contornos e modulações do problema. E esta alteração na interrogação analítica foi aquilo que permitiu desvencilhar-me da rua enquanto experiência de exclusão ou de isolamento, colocando-a como centro de convergência de variados processos.

Nos contatos estabelecidos durante o percurso da pesquisa, percebi também que este campo estava sendo atravessado por discursos cada vez mais politizados. A política era um elemento contínuo na fala dos atores deste campo. Claro que este aspecto "monotemático" da política tinha muito a ver com determinados circuitos de interação que estava acompanhando, como algumas instituições de serviço à população de rua, o Fórum de Debates, as manifestações públicas, além das falas e discussões no interior do Movimento Nacional dos Catadores de Materiais Recicláveis (MNCR) e do Movimento Nacional de Luta e Defesa dos Direitos da População em Situação de Rua (MNPR). Movimentos sociais que comecei a acompanhar mais de perto e nos quais com o tempo passei a ser reconhecido como um pesquisador-colaborador ${ }^{3}$.

No decorrer das conversas e interações em campo, colocavam-se críticas à postura do Estado, discutia-se sobre os limites das políticas públicas, indagava-se sobre qual o papel da igreja e das organizações não governamentais neste processo. Havia um aparente esforço para se falar sobre, para e em nome da população de rua, além das pessoas me perguntarem, na qualidade de pesquisador, como este estudo poderia contribuir nesta questão. Apesar de não ter muitas respostas para as indagações políticas que me eram colocadas, estes questionamentos demonstravam, entre outras coisas, como minha própria compreensão deste universo também era um elemento requisitado.

Ao aproximar-me cada vez mais do tema de pesquisa (inicialmente de graduação e, posteriormente, de pós-graduação), fui sensibilizando-me com a enorme mobilização em torno de certos dilemas e dificuldades próprias à questão da população de rua. Ao colocar-me disponível para algumas tarefas, acredito ter conquistado uma receptividade que me permitiu circular por perspectivas diferentes no interior deste campo. Esta mesma receptividade

\footnotetext{
${ }^{3}$ No desenrolar da pesquisa fui convidado algumas vezes a participar e ajudar na organização de alguns eventos sobre o tema. Contribuí inclusive na relatoria de seminários organizados tanto pelo MNCR quanto pelo MNPR, movimentos sociais que, no decorrer das descrições etnográficas da dissertação, buscarei apresentar mais detalhadamente. Participei, também, dos dois primeiros congressos latino-americanos de catadores de materiais recicláveis, o primeiro em 2003 e o segundo em 2005. Neste processo conheci experiências, pessoas e pesquisadores envolvidos com o tema em outros países do continente. Um primeiro resultado sobre as diferentes experiências dos catadores na América Latina pode ser visto na coletânea Recicloscópio: Miradas sobre recuperadores urbanos de resíduos de América Latina (Schambler; Suárez, 2007), na qual escrevi um artigo sobre a situação dos catadores no centro de São Paulo.
} 
resultou numa certa relação de confiança e, até mesmo, amizade com alguns moradores de rua, agentes institucionais e religiosos. Ao participar de um circuito de troca mais amplo, em algumas situações, tornei-me alvo de desabafos, cumplicidades, pequenos favores e outras demandas mais específicas. Foi esta convivência mais íntima que permitiu cruzar, ainda que momentaneamente, este campo da diferença onde se desenrola o trabalho etnográfico.

Mas também foi esta convivência mais íntima que me permitiu notar como esta questão é sustentada e estimulada pela confluência cruzada de variados discursos, instituições, saberes e poderes especializados. Agenciamentos plurais que buscam, de diferentes maneiras, definir o problema e também solucioná-lo. Ao ter um contato mais aprofundado com a bibliografia especializada sobre população de rua, fui percebendo que uma grande pergunta que paira sobre estes textos era o "porquê da rua". Busca-se saber quem são estas pessoas, o que fazem, de onde vêm, para onde vão, e, o mais importante de tudo, qual a causa da situação de rua? (Bursztyn, 1997; Castelvecchi, 1982a, 1982b; Escorel, 1999; Rosa, 2005; Simões Jr., 1992; Stoffels, 1977; Varanda, 2003; Vieira, Bezerra e Rosa, 1994) Aos poucos, fui notando que esta grande pergunta, "por que as pessoas estão na rua", que atravessava grande parte da literatura especializada, funcionava como uma sombra que encobria, talvez, uma realidade mais assinalável do ponto de vista antropológico. Pelo fato da rua ser na maioria das vezes tratada como um problema a priori, a questão sobre como todo um contingente de agentes, instituições e poderes se comportam frente a este fenômeno, parecia estar ausente ou pelo menos amortizada neste conjunto de estudos. Deste modo, comecei a dar-me conta da necessidade de se explorar esta mobilização em torno de tal fenômeno, traçando as relações e os impasses vividos situacionalmente pelos atores e instituições que convivem diretamente com o este.

Assim, havia um certo hiato na bibliografia sobre população de rua no que concerne aos detalhamentos dos agenciamentos de mediação e processos políticos que propriamente envolvem o tema, e foi precisamente a partir deste hiato que resolvi enveredar minha análise. Como tais processos tinham sido muito pouco estudados e muito menos etnografados, pareceram-me bem importantes para compreender certo número de trajetórias temporais e jogos de força que permitiram e incitaram a invenção desta questão social, os modos de contestação política e os mecanismos institucionais que fundamentam seu estatuto e a produzem enquanto realidade social.

Como o percurso de pesquisa foi pautado por uma gradativa proximidade com o universo etnográfico, as experiências vividas em campo constantemente me induziam à interrogação sobre minha posição nestas relações e quais seus limites analíticos. Interrogações 
que acompanharam todo o processo de produção da pesquisa. Ao reconhecer minha posição como pesquisador-colaborador no interior de um campo de saberes e poderes sobre o morador de rua, foi possível usar a noção de dispositivo para trabalhar não só com a genealogia histórica do fenômeno como também a sua manutenção como questão social. Este mesmo conceito permitiu-me também que olhasse com maior desconfiança para toda mobilização em torno do tema, e do qual eu passara então a fazer parte ${ }^{4}$. Até porque esta reflexão sobre as relações entre engajamento e distanciamento, entre familiaridade e estranhamento, entre participação e pesquisa, não são periféricas, mas sim centrais à prática antropológica.

No entanto, a posição de pesquisador-colaborador não foi um lugar inventado por mim. Esta é uma classificação própria ao campo. Alguns apoiadores de movimentos sociais, bem como alguns participantes do Fórum de Debates sobre População em Situação de Rua apresentam-se publicamente desta forma. Contudo, ao me colocar/ser colocado neste lugar e ao assumir tal classificação já existente, assumi também todas as críticas que lhe são próprias: que o pesquisador trata o morador de rua apenas como um objeto de estudo; que estas pesquisas não servem para nada; que não há utilidade em tantas pesquisas sobre a população de rua; que em vez de pesquisar tanto, devia-se ajudar o morador de rua; além de outras formulações mormente colocadas em tom de acusação. De maneira geral, estas críticas apontam para o fato de que a aproximação do pesquisador com a rua e seus habitantes se faria por interesses puramente acadêmicos, não respeitando as necessidades e dificuldades próprias à pessoa da rua ${ }^{5}$. Não por acaso, Alba Zaluar afirma que a pesquisa também é a "história de um relacionamento pessoal em que o pesquisador procura desfazer as impressões negativas da imagem do 'dominador' a fim de tornar a comunicação ou o encontro possível”. (Zaluar, 1997:115)

Mas se a posição de pesquisador-colaborador, como mostrei, é em si mesma uma posição controversa neste campo, no interior das ciências sociais ela é mais ainda. Isso decorrente das críticas já efetuadas sobre o perigo da militância dos pesquisadores, a conhecida "participação observante" que, ao aceitar não refletidamente as categorias, explicações e acusações formuladas pelos grupos e pessoas estudadas em campo, correria o

\footnotetext{
${ }^{4} \mathrm{O}$ conceito de dispositivo será apresentado mais adiante, bem como suas conexões e efeitos de aplicação no caso aqui analisado.

${ }^{5}$ Presenciei vários casos que atestam uma polêmica sobre a importância ou não das pesquisas sobre a população de rua. Uma acusação semelhante à "exploração científica" que se desenvolve sobre o morador de rua pode ser encontrada, justamente, em relação aos funcionários das instituições, que são vistos como participantes da "indústria da miséria", mercado onde todos profissionais das ONGs e entidades do terceiro setor abiscoitariam os financiamentos públicos e privados, em detrimento das precárias condições de vida do morador de rua. Os impasses e conflitos existentes no interior das instituições e entre usuários e funcionários serão discutidos no capítulo 3 da dissertação.
} 
risco de explicar o universo analisado unicamente através de suas categorias êmicas, invés das antropológicas. (Durham, 1997) Entretanto, insisto no caráter produtivo e não impeditivo desta posição de colaborador-pesquisador, espaço ambíguo e tenso de onde pretendo falar. E para isso, retorno àquela pergunta prática e agonística que me colocava ao ter o primeiro contato com o campo.

Sabe-se que a pergunta “o que se deve fazer?" é uma questão de caráter fundamentalmente militante. Assim, respondê-la é tudo que este trabalho não deseja fazer. Sobre isto é interessante notar a maneira que Homi K. Bhabha busca reafirmar o compromisso com a teoria em suas relações com o político. Ao comentar justamente a pergunta "o que deve ser feito?", afirma que esta deve ser entendida "como matriz produtiva que define o social e o torna disponível como objetivo da e para a ação". (Bhabha, 2003:48). Esta pergunta feita pelo ativista implica em si mesma uma concepção sobre o que é o mundo social e sobre como atuar nele, é um modo de agência que já implica numa certa compreensão sobre aquilo que age. Deste modo, não abandonei esta questão, que desde o início da pesquisa rondava a experiência de campo, mas apenas remanejei sua posição no interior de minhas preocupações investigativas, assentado-a como um dos próprios objetos da análise. Ou seja, ver como a realidade social destes atores é produzida por meio de suas próprias experiências de vida e práticas interdependentes, umas em relação às outras. Assim, ao identificar-me com os modos de subjetivação e interrogação que os próprios atores colocavam sobre si e sobre as relações nas quais estavam inseridos, pude acessar não unicamente uma experiência da dúvida, mas também formas de respostas práticas situacionalmente ativadas. E neste caminho, acredito ter sido possível aproximar-se mais das elaborações discursivas, tanto de seus questionamentos, como suas resoluções.

Neste mesmo texto, Bhabha argumenta que a função da teoria no interior do processo político possui um caráter duplo: ela nos chama a atenção para o fato de que nossos referentes e prioridades políticas não existem com um sentido primordial, e também nos faz ver como o objeto político só faz sentido quando vem a ser construído nos discursos cujos objetos de prioridade estão sempre em tensão e em referência cruzada com outros objetivos. (Bhabha, 2003:53) Assim, se é verdade que, em alguns casos, passei a ser visto como um aliado político no campo estudado, também é verdade que é extremamente difícil identificar qualquer "objetivo" especifico e restrito em jogos dinâmicos de lealdade. Em minha pesquisa isso se deu basicamente por dois motivos interconectados. Um foi que a própria "causa primordial" em questão - a população de rua - é um objeto provisório cuja definição não se faz sem dissenso e desentendimentos, e cujo significado é resultado da própria luta política. 
Outro motivo foi que, ao privilegiar experiências de campo heterogêneas e cruzadas, tentei dificultar a construção uma perspectiva fixa a algum interesse mais circunscrito ${ }^{6}$. Assim, da mesma forma que problematizei minha posição no campo analisado, também me esforcei numa vigilância conceitual de maneira a embaraçar a construção de uma identidade simples entre o objetivo político dos atores do campo e seus meios de representação. O desafio que me coloquei durante a pesquisa foi o de ver nestes atores sujeitos descontínuos, presos a identidades e interesses também conflitantes, assim como os do próprio pesquisador.

Sustento, deste modo, que esta minha dupla inserção neste campo, apesar de ser uma posição carregada de incertezas e ambivalências, é um bom lugar para se fazer pesquisa. Justamente por encontrar-me na zona de contato entre dois modos de ação, o antropológico e o do próprio campo de estudo, este lugar de fala é potencialmente revelador. É este contato que permite facilitar o fluxo e trânsito de informações e, deste modo, iluminar certas perspectivas que de outra forma seriam inapreensíveis. Ao ocupar este entre-lugar, acredito ter sido capaz de articular e estranhar as diferenças operantes nestas duas linguagens e deste confronto apresentar algo novo. É este espaço da dupla inscrição que me permitiu relativizar e contextualizar posições, vê-las como alteridades e propor traduções capazes de ultrapassar oposições dadas e polaridades simplistas tais como aquelas entre o teórico e o político, o progressista e o reacionário.

Clifford Geertz, para quem a pesquisa científica social deve ser compreendida também como uma experiência moral, argumenta que o trabalho de campo antropológico obriga a uma combinação entre a atitude engajada e analítica. Olhar para os acontecimentos, pessoas e si mesmo, "com um olhar ao mesmo tempo frio e interessado é um dos sinais mais seguros de maturidade". (Geertz, 2001:45) Assim, meu exercício de campo foi justamente o de tornar exótico um universo que gradativamente tornou-se familiar para mim, e, neste processo, familiarizar-me com estranhezas antes desconhecidas. Foi através deste movimento que fui capaz de construir um distanciamento que, como diz Geertz, "não é um dom natural, nem um talento fabricado, mas uma conquista parcial laboriosamente alcançada e precariamente mantida" (Geertz, 2001:44).

Por fim, não quero afirmar que a combinação de pesquisa e participação no campo é algo bom ou ruim em si mesmo, mas sou obrigado a dizer que foi justamente esta minha

\footnotetext{
${ }^{6}$ Diferente de alguns outros trabalhos de antropologia urbana, não busquei seguir um grupo específico, mas privilegiar cruzamentos etnográficos entre heterogêneos. Uma exceção talvez tenha sido o caso da etnografia do albergue, quando desenvolvi um trabalho de campo mais aprofundado numa instituição específica na qual dormi, comi e interagi diretamente com usuários e funcionários. Contudo, mesmo a experiência de campo nesta instituição foi situada, informada e confrontada por visitas e conversas em outros albergues e instituições.
} 
participação que possibilitou a realização deste estudo. Sem esta proximidade não seria visto "como de confiança”, nem teria acesso a certas pessoas, informações e instituições, trânsito precisamente através do qual meu conhecimento foi sendo produzido, contestado e colocado em jogo. Obviamente este acesso "privilegiado" permitiu-me ter contato com uma multidão de informações deste universo. Estas informações, apesar de terem sido muito importantes para a construção e elaboração da problemática, não foram diretamente utilizadas, tampouco descritas detalhadamente no corpo da dissertação. É válido ressaltar, no entanto, que no momento em que coletei o material de campo utilizado para as descrições etnográficas, minha posição de pesquisador estava mais do que clara.

Esta posição de proximidade, entretanto, implica na possibilidade de não enxergar certas perspectivas, implica numa parcialidade. Parcialidade que é a própria condição de objetividade, já que "apenas a perspectiva parcial promete visão objetiva" (Haraway, 1995:22). Objetividade não remete a uma verdade supostamente neutra, remete sim à capacidade de explicitar, até onde for possível, as condições de produção de pesquisa e o lugar de fala do pesquisador. Implica também em reconhecer a parcialidade que reside em todo saber. "O conhecimento deve ser situado e corporificado contra as várias formas de postulados de conhecimento não localizáveis e, portanto, irresponsáveis. Irresponsável significa incapaz de ser chamado a prestar contas" (Haraway, 1995:23). É com a intenção de um dia ser capaz de prestar contas, em relação às formulações aqui apresentadas, que insisto no caráter parcial e, portanto, objetivo deste trabalho.

\subsection{Hipótese e campo de problematização}

A hipótese mais ampla que organiza esta dissertação é que, problema de multiplicação e controle, a população de rua, tal como é hoje, não existiu desde sempre, sendo invenção social recente e bem datada em nosso país. Uma reconfiguração daquele antigo mendigo cuja imagem ligava-se unicamente à prática circunscrita da mendicância nas ruas e ao fracasso moral e individual - inicia-se na passagem para a década de oitenta e consolida-se no início do novo século. Nestes anos vimos a experiência das ruas ganhar outros contornos, novos indicadores e evoluir velozmente. Junto a isso se estabelece uma complexa e entremeada arena de interações na qual uma série de discursos, práticas e instituições disputam e produzem valores específicos, mas também propõem soluções para a crescente população que habita o espaço público da cidade. Ao mesmo tempo em que aumenta o número de pessoas vivendo nas ruas, todo um conjunto de atores coletivos, ONGs, entidades 
religiosas, organismos estatais e figuras políticas e intelectuais, começam a entrar em conexão e concorrência pela definição e delimitação do que é população de rua, como se deve tratá-los, quem deve tratá-los, quais técnicas adequadas de tratamento, quem deve falar para eles, por eles e sobre eles, e qual o papel de cada um destes agentes em tal dinâmico contexto.

Até então inumerável, invisível e inominável, nos últimos trinta anos a experiência das ruas ganha número, visibilidade e nome próprio - população de rua - e assim entra na cena do espaço público paulistano e também de outras cidades do Brasil. Particularmente no centro de São Paulo a população de rua parece que está em todo lugar. É alvo de discursos e olhares, regimes enunciativos e de visibilidade. São implantados insistentes dispositivos para se ouvir, ver, registrar e falar da população de rua. Discursividades múltiplas são incitadas: declarações públicas, artigos de jornais, periódicos científicos, monografias, pesquisas estatísticas, livrosdepoimentos. Visibilidades também são suscitadas: câmeras, filmes, fotos, sistemas de informação, mapeamentos estatísticos, cartazes, manifestações no espaço público. Sem falar nos agentes, instituições e outras instâncias mais especializadas: ONGs, albergues, uma lei municipal própria, blogs de discussão, datas e periódicos específicos, Pastoral do Povo da Rua, fóruns e mais fóruns, e, agora, um comitê interministerial próprio e um movimento social de escala nacional ${ }^{7}$.

Vemos, deste modo, como hoje a experiência de rua é interrogada e colonizada por um imenso campo discursivo e prático. Toda esta heterogênea rede de atores, instituições e saberes parecem carregar consigo a premissa de que é inconcebível que alguém esteja habitando as ruas da cidade. E tal premissa é justificada através de várias formas: a rua não é um lugar legítimo e digno de vida, é insalubre e prolifera doença, é espaço de abandono, anonimato e violência, além de atrapalhar a circulação e gerar insegurança entre os transeuntes, morar na rua também é uma prática juridicamente inaceitável já que por lei todos temos um direito à moradia. Estas diferentes justificativas podem ser encontradas em leis, projetos urbanísticos, periódicos, protestos e outros discursos públicos, contudo, elas insistem e se tangenciam em pelo menos num ponto em comum: a experiência de vida nas ruas é algo

\footnotetext{
${ }^{7}$ O crescente aumento do número de notícias de jornal sobre este fenômeno pode ser consultado em Rosa. (1999) O impressionante aumento de pesquisas sobre o tema, particularmente em disciplinas como psicologia, assistência social, terapia ocupacional, teologia e pedagogia está registrado na Bibliografia levantada pelo Fórum de Debates sobre População em Situação de Rua. Já existem algumas publicações de caráter auto-biográfico que apresentam textualmente a experiência de vida nas ruas. Também vários filmes já foram produzidos com esta temática. Um dos mais conhecidos é A margem da imagem de Mocarzel (2003). Sobre a representação e imagem dos personagens de rua no cinema ver Frangella. (2004) O SISRUA (Sistema Integrado de Informação sobre a População de Rua) implantado na rede de atendimento será melhor apresentado no capítulo 4. As manifestações públicas serão analisadas no capítulo 3. A comentada lei refere-se à Lei de Atenção à População em Situação de Rua que será melhor discutida, em seus usos e efeitos, no decorrer da dissertação. A citada data específica, diz respeito ao Dia de Luta do Povo da Rua, e os periódicos dizem respeito ao jornal $O$ Trecheiro e à revista $O C A S$.
} 
inaceitável ${ }^{8}$. Assim, o insuportável expresso na experiência de rua é justamente o postulado e o acordo tácito capaz de aglutinar e fornecer apoios recíprocos às múltiplas e antagônicas vozes que atravessam e emanam do tema.

Contudo, ao mesmo tempo em que se aumentam os agentes de proteção e se desenvolvem mais estratégias para diminuir este contingente populacional, os números que registram sua existência estatística crescem e multiplicam-se cada vez mais. Foi em São Paulo, na década de noventa, que se iniciou a contagem das pessoas que vivem neste universo, pessoas que, até então, sequer apareciam no cômputo dos censos nacionais. Segundo a Fundação Instituto de Pesquisas Econômicas (FIPE, 2000, 2003), instituição responsável pelos dois últimos levantamentos da população de rua, o número deste contingente (considerado como os usuários de albergues e as pessoas que pernoitam nas ruas) em 1991 eram 3.392 pessoas nesta situação e em 2003 o número saltou para 10.394. Atualmente se estima que este número supere os 12.000 e segundo a mesma fonte, a maior parte desta população são homens que vivem respectivamente nos distritos da Sé, República, Brás e Liberdade. Simultaneamente a este espantoso aumento numérico do fenômeno, intensificam-se também práticas para evitar seu crescimento.

É notável, portanto, como a experiência das ruas passou a ser colocada em termos de um "problema social e urbano". Problema que se multiplica e deve ser controlado, tema que incomoda e mobiliza toda uma variedade de agentes. Estes, por sua vez, passaram a engajarse, de múltiplas formas, na resolução, prescrição, adesão e inteligibilidade da questão. Seria, pois, necessário problematizar os processos que levaram a configuração desta questão social à qual se convencionou chamar contemporaneamente como população de rua.

Segundo Foucault, problematizar é uma forma de analisar e elaborar os problemas que a experiência coloca para a ação política em determinada formação histórica. A análise das problematizações procura interrogar a política por aquilo que diz e faz a respeito dos problemas com os quais é confrontada, busca questões que se colocam, para um determinado campo de relações, como podendo e devendo ser pensadas. (Foucault, 2001d:15, 2002:25) É preciso que fatores se tornem incertos e dificultosos para que se cobre intervenções que assumam formas variadas, respostas multifacetadas e soluções diferentes para um problema historicamente colocado. E o "problema" aqui colocado é a própria população de rua. Assim, o objetivo desta dissertação não se refere à população de rua em si, tampouco se trata de

\footnotetext{
${ }^{8}$ Estas justificativas, e muitas outras, foram ouvidas no trabalho de campo. Contudo, a frase desesperada que também ouvi, e acredito ser o efeito do estranhamento produzido pelo contato primeiro com este universo, "alguém tem que fazer alguma coisa para tirar as pessoas desta situação!", parece ser o único ponto em comum a partir do qual todo um complicado edifício de discórdias e controvérsias foi arquitetado.
} 
defini-la ou descobrir alguma verdade que residiria por trás desta experiência. A proposta deste trabalho é descrever etnograficamente alguns dos mecanismos locais e parciais pelo qual a população de rua é constituída historicamente, contestada politicamente e regulada institucionalmente como questão social. Ou seja, problematizá-la em seu campo imanente de ação para, assim, analisar a qualidade das relações que se estabelecem através dos atores, eventos e instituições que dão forma a esta questão.

\subsection{Articulação conceitual}

A perspectiva teórica deste trabalho encontrou muito apoio nas obras de Michel Foucault, apesar de maneira alguma restringir-se a tal conjunto de obras. Não se limitando a nenhum campo disciplinar especifico, este autor buscou, em seus livros, jogar de diferentes maneiras com as dobras de nossa modernidade, atentando para a construção de alteridades liminares no Ocidente e suas formas de conhecimento, relações de poder e modos de subjetivação. Ao historicizar e colocar no seio de relações sociais as grandiosas abstrações e verdades produzidas pelo Ocidente, este autor criou um tipo de estranhamento digno da atenção de antropólogos urbanos. Para Foucault não há posição externa de certeza, não há compreensão transcendental que esteja além da história e do jogo social. Os objetos e sujeitos possuem um solo comum, podem ser sempre localizados e situados historicamente e, assim, analisados através de fios discursivos e práticos que os tecem e dão vida. Ao transformar os universais humanos em categorias êmicas da modernidade - categorias que desempenham efeitos muito específicos em contextos determinados -, este autor assume uma postura epistemológica que o aproxima da abordagem própria à antropologia, que analisa seus objetos etnográficos como um conjunto de práticas sociais em complexas relações pragmáticas com uma congeneridade de símbolos. (Rabinow, 2002)

Entretanto, diferente da antropologia mais tradicional, Foucault vê nas relações de poder a chave de inteligibilidade para o funcionamento do próprio campo social. Sem querer esgotar o assunto, é importante enfatizar que a noção de poder manuseada por Foucault possui contornos muito específicos que valem ser rapidamente apresentados. O poder não é atributo, mas relação, feixes abertos de relação de forças. É menos uma propriedade que uma estratégia, e seus efeitos, sempre locais, parciais e situados, são atribuídos ao movimento de disposições, distribuições, manobras, técnicas e táticas. Só existindo em ato, o poder é "uma ação sobre ações". (Foucault, 1995:243). Sobre isso, Deleuze, um dos principais comentaristas e interlocutores de Foucault, reitera que "O poder não é essencialmente 
repressivo (já que incita, suscita, produz); ele se exerce antes de se possuir; passa pelos dominantes tanto quanto pelos dominados". (Deleuze, 2005:79) Aqui reside o caráter estritamente relacional das correlações de poder, já que estas "não podem existir senão em função de uma multiplicidade de pontos de resistências que representam, nas relações de poder, o papel de adversário, de alvo, de apoio, de saliência que permite a preensão. Esses pontos de resistência estão presentes em toda a rede de poder" (Foucault, 2001c:91).

Ao analisar as relações de poder e, portanto, o próprio campo social, a pergunta que Foucault coloca perante seus objetos e materiais empíricos, é justamente a do "como o poder se exerce?" (Foucault, 1995:240). Em vez de julgar e avaliar como positivo ou negativo, assume uma postura preocupada em ver como componentes históricos funcionam, como estes elementos se exercem uns nos outros, como produzem certos efeitos e como a partir daí se arma um campo de problematização através de várias intervenções, deslocamentos e posicionamentos. A propósito disto é interessante notar que Paul Rabinow reconhece que esta postura diante dos objetos analisados é uma postura tradicionalmente etnográfica, já que busca não se comprometer e nem se opor, mas compreender racionalidades específicas operantes para descrever e compreender o que esta acontecendo (Rabinow, 2002:137). E esta pergunta descritiva, o “como?", é a pergunta chave que orienta toda minha investigação e que será perseguida durante toda dissertação.

Não pretendo tomar aqui os trabalhos de Foucault, e de outros, como teoria que possa oferecer leis gerais sobre algo. Pode-se dizer que Foucault nunca pretendeu formular uma teoria geral (Deleuze, 2005), sua atenção sempre esteve mais voltada à analítica das práticas sociais, relações de poder, de saber e seus encadeamentos concretos. Assim, na montagem desta dissertação pretendo utilizar algumas formulações conceituais de sua obra como "caixas de ferramentas". Tanto para Foucault quanto para Deleuze, a teoria deve ser capaz de funcionar e servir adequadamente aos problemas que estão sendo trabalhados. Os conceitos e instrumentais teóricos utilizados devem gerar efeitos e produzir resultados, senão não valem nada. Deste modo, a forma de se montar questões e a maneira de se construir uma problemática deve ser sempre efetuada a partir de ferramentas intelectuais que dialoguem diretamente com o objeto manuseado. Os estudos necessitam, portanto, não de uma teoria global e universal, e sim de idéias dotadas de aplicabilidade e instrumentalidade específicas e relativas aos materiais analisados. Por isso apresento adiante o esquema mais geral no qual edifiquei as questões da pesquisa. Posteriormente, apresento o conjunto das estratégias conceituais e metodológicas próprias a uma antropologia urbana e que aqui foram operacionalizadas na construção deste trabalho. 


\subsubsection{Sobre o dispositivo}

Seguindo a hipótese anteriormente apresentada, que a população de rua tornou-se recentemente um grande domínio de ingerência urbana, é possível afirmar que neste processo formou-se historicamente um dispositivo para a gestão desta população. Contudo, o que é um dispositivo?

O conceito de dispositivo aparece na obra de Foucault justamente quando o autor passa a se dedicar ao estudo das práticas sociais. Nesta passagem vemos o abandono da noção anterior de episteme - quando Foucault buscava referir-se unicamente às estratégias discursivas - para a construção de um conceito capaz de lidar simultaneamente com um conjunto de práticas discursivas e não discursivas. Para Dreyfus e Rabinow a noção que melhor se aplicaria ao entendimento do conceito de dispositivo seria a de rede de inteligibilidade, uma grade de análise construída pelo pesquisador de maneira a isolar um problema específico 9 . Quando se torna possível isolar relações de força que suportam formas de saber e vice-versa, teríamos aí um dispositivo histórico. Entretanto, os dois autores concordam que a compreensão do dispositivo unicamente como um procedimento metodológico subestima, em muito, a "tentativa de Foucault em desvelar as práticas por elas mesmas". (Dreyfus; Rabinow, 1995:134) Assim, o dispositivo é, ao mesmo tempo, uma grade analítica, mas também, uma teia de práticas concretas cujas relações apresentam racionalidades e inteligibilidades imanentes que o analista deve trazer à tona. Numa das raras definições precisas e detalhadas do conceito, Foucault apresenta assim o dispositivo:

Através deste termo tento demarcar, em primeiro lugar, um conjunto decididamente heterogêneo que engloba discursos, instituições, organizações arquitetônicas, decisões regulamentares, leis, medidas administrativas, enunciados científicos, proposições filosóficas, morais, filantrópicas. Em suma, o dito e o não dito são os elementos do dispositivo. $O$ dispositivo é a rede que se pode estabelecer entre estes elementos.

Em segundo lugar, gostaria de demarcar a natureza da relação que pode existir entre estes elementos heterogêneos. Sendo assim, tal discurso pode aparecer como programa de uma instituição ou, ao contrário, como elemento que permite justificar e mascarar uma prática que permanece muda; pode ainda funcionar como reinterpretação desta prática, dando-lhe acesso

\footnotetext{
9 Como não há um termo equivalente ao dispositivo em inglês, os tradutores de Foucault nesta língua empregaram o termo "aparelho", uma palavra que também convêm à sua noção pragmática de que os conceitos devem ser utilizados como ferramentas para a análise e não fins em si mesmos. (Dreyfus; Rabinow, 1995)
} 
a um novo campo de racionalidade. Em suma, entre estes elementos, discursivos ou não, existe um tipo de jogo, ou seja, mudanças de posição, modificações de funções, que também podem ser muito diferentes.

Em terceiro lugar, entendo dispositivo como um tipo de formação que, em determinado momento histórico, teve como função principal responder a uma urgência. O dispositivo tem, portanto, uma função estratégica dominante. Este foi o caso, por exemplo, da absorção de uma massa da população flutuante que uma economia de tipo essencialmente mercantilista achava incômoda: existe aí um imperativo estratégico funcionando como matriz de um dispositivo que pouco a pouco tornou-se o dispositivo de controle-dominação da loucura, da doença mental, da neurose. (Foucault, 2001b:244)

O dispositivo é entendido, então, como uma rede articulada de componentes disparatados que possui uma gênese histórica, configurando-se enquanto um conjunto de práticas que se conectam, mediante relações de força, no espaço e no tempo. A constituição do dispositivo está ligada ao surgimento de uma necessidade histórica resultante de um acontecimento que se torna objeto estratégico de múltiplos agenciamentos. E este acontecimento, com o qual o dispositivo aqui analisado teria de lidar, é justamente o aparecimento da população de rua num dado campo social na cidade de São Paulo. Este acontecimento, a emergência da população de rua enquanto um domínio próprio de poderes e saberes, não obstante seja datado e localizado, a transformação que produz e da qual é produto, irradia-se encontrando ressonância em uma multiplicidade de outros agenciamentos operantes.

Para Foucault, entre os elementos heterogêneos que compõem o dispositivo, há uma espécie de jogo tático incessante, "pois cada efeito, positivo ou negativo, desejado ou não, estabelece uma relação de ressonância ou de contradição com os outros, e exige uma rearticulação, um reajustamento dos elementos heterogêneos que surgem dispersamente". (Foucault, 2001b:245) Este perpétuo preenchimento articulatório diz respeito aos efeitos inesperados que vão surgindo, insurgindo e conectando-se com outros elementos no desenrolar dos processos. O dispositivo não diz respeito a uma causa primeira, seu preenchimento é sempre estratégico, resultado de infinitas ações que vão acomodando-se umas sobre outras e estabelecendo entre si correlações de forças e apoios recíprocos.

Um aspecto interessante deste conceito, é que ele possibilita escapar daquilo que seria um estudo voltado à representação da população de rua e seu suposto significado profundo. Ele permite abandonar o imaginário da profundidade para ater-se à realidade dos "efeitos de 
superfície" possibilitando, assim, captar práticas e discursos nos pontos de inscrição em que se formam e amarram elementos tão heterogêneos quanto enunciados, modos de tratamento, medidas administrativas, leis, disposições regulamentares e projetos arquitetônicos. Problema, portanto, muito mais de "vizinhança”, do que "fundação". (Foucault, 2006a:463) Deste modo, são convenções que não pertencem apenas ao universo da representação, pois "subtende regras que dão forma jurídica ou administrativa às relações sociais, que informa as categorias que permitem ler a experiência dos atores e que a estruturam, apóia-se em objetos que constituem o âmbito ou o meio da ação". (Lepetit, 2001:167) Em seus estudos Foucault mostrou que a loucura apareceu no Ocidente junto com o nascimento da clínica e do saber psiquiátrico (Foucault, 2006a). De maneira semelhante, também apresentou o nascimento da prisão como fenômeno conjugado ao problema da delinqüência e à institucionalização da polícia como aparelho de otimização da ordem social (Foucault, 2001a). Cada um desses objetos, instituições, regras e práticas adjacentes, se elabora num contexto particular e conectado, mas possui uma durabilidade e um tempo diferenciado em relação ao contexto que o engendrou.

Deste modo, para Foucault, em determinadas condições históricas, saberes, poderes e seus alvos de ação emergem conectados uns aos outros - como que por "vizinhança", "contágio" e "proliferação" - fazendo com que múltiplas ocorrências sobredeterminem e articulem sujeitos e objetos (Rabinow e Dreyfus, 1995). Vemos, então, como estes elementos não aparecem necessariamente um depois do outro, eles vão se arranjando espacial e temporalmente através de jogos de ação e reação, apropriações e deslocamentos, de avanços e recuos. A condição de produção destes objetos é precisamente a ramificada rede de conexões na qual cada um apóia-se. Conexões que são travadas em meio a processos sempre singulares que produzem efeitos variados. E nestes acontecimentos históricos, que imprimem descontinuidades no curso dos processos, não há autoria exclusiva, ninguém é seu sujeito completo; neste plano o sujeito é sempre uma derivada e as relações são sempre mistas, entrecruzadas e mais ou menos dispersas em suas determinações.

Com isso, seria enganoso pensar que unicamente a partir de um acontecimento, neste caso o nascimento da população de rua, é que seu dispositivo pôde ser instalado. Colocar o problema nestes termos nos remete à interminável pergunta a respeito da anterioridade do ovo ou da galinha. O que o trabalho de Foucault nos mostra é que os enunciados históricos emergem atrelados uns aos outros. É o dispositivo que cobra uma proliferação discursiva e prática de seu alvo. Ele o induz, interroga e solicita, obrigando-o a uma existência ativa em relações com outros termos. Em suma, é o dispositivo da população de rua - o jogo de seus 
discursos, agentes, instituições e regulamentos - que define esta realidade. E por conseguinte, é somente a partir deste jogo de forças que os agentes podem contestá-lo, deslocá-lo e jogar com ele.

O conceito de dispositivo foi aqui apresentado em sua concepção mais geral e global, contudo é importante comentar que este termo é, grande parte das vezes, utilizado por Foucault como engenhos de poder flexíveis e presentes em variadas escalas de ação, sendo a proposta, decifrar "quais são, em seus mecanismos, em seus efeitos, em suas relações, esses diferentes dispositivos de poder que se exercem, em níveis diferentes da sociedade, em campos e com extensões tão variados." (Foucault, 2002c:19). Assim, quanto mais dilatada a escala de ação considerada, mais parece "não haver mais ninguém para tê-las concebido e formulá-las: caráter implícito das grandes estratégias anônimas”. (Foucault, 2001c:91) Por isso, Foucault afirma que "nenhuma estratégia poderia proporcionar efeitos globais a não ser apoiada em relações precisas e tênues que lhe servissem, não de aplicação e conseqüência, mas de suporte e ponto de fixação. Entre elas, nenhuma descontinuidade, como seria o caso de dois níveis diferentes (um microscópico e o outro macroscópico); mas, também, nenhuma homogeneidade (como se um nada mais fosse do que a projeção ampliada ou a miniaturização do outro); ao contrário, deve-se pensar em duplo condicionamento, de uma estratégia, através da especificidade das táticas possíveis e, das táticas, pelo invólucro estratégico que as faz funcionar" (Foucault, 2001c:95)

Deste modo, os dispositivos de conjunto só poderiam aparecer através da miríade de focos locais e muito específicos, que fornecem apoio, os situam e os conformam em variados jogos de escala. São estas relações de força, microfísicas, multipontuais e difusas, que determinam as singularidades capazes de desenhar um diagrama de relações e que montam o dispositivo da população de rua, tal como aqui foi anunciado. Estas práticas moleculares diminutas invenções e mecanismos por onde variações e diferenciações "correm por todos os lados" - não estão de maneira alguma soltas, mas engatam-se e conectam-se muito bem a outros encadeamentos concretos, às "pequenas válvulas, esses pequenos difusores, essas minúsculas engrenagens, essas microscópicas sinapses através da qual o poder passa e se acha reconduzido por ele mesmo". (Foucault, 2006b:95)

Escolhi o conceito de dispositivo como eixo articulatório das construções analíticas mais gerais deste trabalho por dois motivos interligados. Um é que ele foi construído justamente com o intuito de compreender fenômenos próximos àqueles que aqui estudo. Assim, do mesmo modo que a população de rua apareceu na história mais recente como um problema de gestão, Foucault mostrou como, por meio de uma complicada aparelhagem 
técnica e discursiva, certas alteridades e figuras, até então banais e opacas, gradativamente transformaram-se em objeto de um tipo de colonialismo interno ao próprio Ocidente. (Bhabha, 2003) Assim, a população de rua e seu campo de aparecimento, podem ser mais bem compreendidos como mais um dos modernos domínios de ingerência e gestão das populações tidas como de risco.

Já o outro motivo, para a eleição do dispositivo como conceito estratégico na montagem da pesquisa, é devido à sua maior possibilidade de abertura conceitual. Pelo fato de Foucault constantemente atrelar a este conceito outras noções, acredito que o dispositivo permite uma melhor articulação com outros dois descritores narrativos que aqui também serão conjuntamente manipulados: a idéia de um campo de forças e de uma rede de linhas que atravessam e conformam a experiência social. Contudo, ambas as noções, serão utilizadas, menos como construções conceituais provindas de diferentes, e já consagradas, filiações teóricas, e mais como descritores estratégicos de processos empíricos e situações concretas ${ }^{10}$.

\subsubsection{Experiência urbana e conexões parciais}

Uma das principais preocupações deste trabalho é apreciar e analisar parcialmente as conexões de sentido e relações de força que atravessam a questão população de rua, levando em consideração suas mediações com outros processos urbanos. Deste modo, este trabalho busca situar-se na intersecção dos estudos sobre população adulta de rua com os estudos urbanos, visto que a maioria dos estudos sobre a população de rua em São Paulo estabelece conexões muito marginais com as pesquisas sobre a própria cidade ${ }^{11}$. E a vantagem do

\footnotetext{
${ }^{10}$ Apesar de alguns autores - como Latour (2000) - alegarem certa incompatibilidade no uso conjunto destas noções, acredito que como "ferramentas conceituais" aquilo que permite uma real distância ou aproximação entre ambas, é mais sua manipulação na escrita e no desenrolar do trabalho analítico e textual, do que, propriamente, uma definição teórica pré-estabelecida. Mas talvez caiba assinalar que, apesar de indispor-se não explicadamente com a noção de campo de força, Latour reconhece no conceito de dispositivo uma das principais contribuições da obra de Foucault aos estudos sócio-técnicos, justamente por permitir reverter as escalas de importância macro-micro e abandonar as análises de "profundidade" dando mais atenção aos múltiplos efeitos de "superfície". Sobre as relações entre Foucault e Latour, ver Leal, 2007.

${ }^{11}$ Cabe assinalar aqui pelo menos duas importantes exceções. Uma é o pioneiro trabalho de Marie-Ghislaine Stoffels (1977) Os mendigos na cidade de São Paulo, ao que tudo indica a primeira pesquisa em ciências sociais sobre o tema no Brasil. Nota-se, contudo, que a categoria população de rua ainda não era usada. Este estudo foi muito influenciado pelas pesquisas da década de setenta que então se desenrolavam na periferia de São Paulo. Sobre isto Nestor Perlongher (1989) comenta que este trabalho foi a única referência sociológica que encontrou sobre classes populares no centro da cidade, quando então fora estudar o negócio dos michês também na região central. Em 2005 tive a oportunidade de me encontrar com Stoffels quando ela esteve no Brasil e tive conhecimento das condições e dificuldades encontradas na época para efetuar esta pesquisa. Uma outra importante exceção, muito mais recente, é o formidável trabalho de Frangella (2005), onde a autora faz uma profunda discussão sobre a relação entre o corpo do morador de rua e a própria dinâmica urbana de São Paulo.
} 
conceito de dispositivo para um estudo urbano é que ele situa pragmaticamente os processos, incluindo numa mesma configuração coisas, pessoas e lugares. Esta materialidade dos processos é algo de fundamental importância para o tipo de antropologia que aqui se busca explorar, pois permite colocar a própria dinâmica urbana, com todos seus equipamentos, financiamentos, constrangimentos, fluxos e diretrizes, como uma importante dimensão do problema. Pelo fato de ser estratégia em ação e instituição cristalizada, o dispositivo possui ao mesmo tempo flexibilidade e solidez, fluidez e durabilidade (Deleuze, 2005).

Dar materialidade aos processos implica em situá-los espaço-temporalmente, em localizá-los e posicioná-los, em reconhecer que não haveria cidade se não houvesse redes técnicas para suportar as trocas de produtos, de pessoas, de informações, de signos - tudo que constitui o metabolismo urbano (Telles, 2006). O espaço urbano, visto como obra humana e uma das expressões materiais mais contundentes da capacidade social de se apropriar da natureza e transformá-la, faz com que esta última seja vista como contraponto da própria cidade. Neste movimento a cidade torna-se não-natureza, torna-se a própria antítese do que seria a "natureza". Contudo, embora se associe a natureza à "terra verdejante", intocada pelos homens, é preciso considerar que a cidade e o processo urbano são uma rede de processos entrelaçados a um só tempo humanos e naturais, reais e fictícios, mecânicos e orgânicos (Swyngedouw, 2001). A questão não é insistir na existência de uma infra-estrutura, mas nas práticas que definem formas de apropriação, de usos e de sentidos, tendo consciência de que territórios, equipamentos e artefatos podem canalizar fisicamente processos sociais, e estes, por sua vez, podem produzir novas bases materiais para a ação. Há uma constante e tensa articulação entre processo e forma, sujeito e objeto, atividade e coisa, articulação esta que a análise, uma hora ou outra, deve levar em consideração, pois assim, segundo David Harvey, "verificamos que as coisas estão sempre em transformação, que as atividades estão sempre escapando das formas fixas, que as qualidades objetivadas do urbano são cronicamente instáveis" (2005:170).

O desafio de se enredar por uma antropologia urbana apontaria não para a leitura da cidade como uma "variável independente", forjando uma "cultura urbana" nos moldes da Escola de Chicago, tampouco como uma "variável dependente" do modo de produção capitalista, como fizeram aqueles que, no final da década de 70, tentaram integrar diretamente a interpretação do fenômeno urbano com a teoria marxista (Frúgoli Jr., 2005a). A questão também não é colocar simplesmente o urbano como cenário, palco ou contexto onde as coisas desenrolam. O exercício é inserir a especificidade da cidade, este lugar onde as relações de proximidade e distância coexistem e fenômenos distintos interagem intensivamente em 
combinações variadas, no interior do problema antropológico a ser estudado (Hannerz, 1980), neste caso as relações que cruzam e gravitam em torno da população de rua. O desafio é explorar os variados e possíveis confrontos de trajetórias, eventos e lugares, instâncias estas sempre situadas e localizadas relacionalmente, atentando para a necessidade de se compreender a articulação da diferença, a negociação do significado e, por conseguinte, a produção, ainda que instável, plural e provisória, da cultura urbana.

Este tipo de análise baliza a necessidade de compreender a cidade não como um mosaico de sociabilidades onde imperaria um certo tipo de isomorfismo entre espaços e grupos sociais, tampouco como um conjunto de arranjos sociais singulares e insulados, formas culturais circunscritas em nichos metropolitanos. A distinção entre um mosaico e um espaço atravessado por vetores de estratificação e hierarquização é que "em um mosaico a diferença é reduzida e reificada em uma única dimensão espacial, que se abstrai da diferenciação política mais dinâmica e multifacetada do espaço" (tradução minha, Smith, 2002:137). A antropologia clássica sempre esteve habituada a considerar as culturas em termos de estruturas de significação distintas - geralmente intimamente vinculadas a territórios delimitados - e de indivíduos que se sentem vinculados a essas culturas (Hannerz, 1988; Fergunson e Gupta, 2000). O desafio aqui é colocar em suspenso, ao menos temporariamente, referências homogeneizadoras como grupo e comunidade, e atentar mais para as operações do vínculo, as redes de relações e as cadeias de mediações, reconstituídas através de etnografias de itinerários e situações sociais, colocando, deste modo, a própria cidade em perspectiva.

Seguindo a sugestão de Isaac Joseph, que concebe a dinâmica da cidade como "algo esponjoso que repele e atrai ao mesmo tempo" (Joseph, 2005), pretendo colocar a experiência urbana sob o signo da circulação e da mobilidade, reconhecê-la como um verdadeiro "canteiro de obras culturais". A aposta é assentá-la em termos de porosidade, uma idéia de Joseph que sugere a permeabilidade dos lugares e das identidades, pois estes estão sempre extrovertidos, voltados para um "fora". A cidade é, portanto, uma conjunção estruturalmente instável e marcada por uma espécie de mutabilidade gasosa, hipersensível às menores vibrações sociais. E a cultura urbana seria precisamente este cruzamento onde tudo pode se intercambiar e se experimentar, mediante tensões e forças em jogo. Apresentar a cultura no singular não implica omitir sua diversidade, e sim acenar para o desafio de se tentar compreender a diferença por meio da conexão. O problema é justamente o de conseguir explorar as formas interdependentes de organização e produção da diversidade, a pluralidade dos mundos urbanos, seguindo atentamente a multiplicidade de lealdades nas quais os atores enredam-se, 
o trânsito contínuo dos laços sociais e os ajuntamentos mistos, estes espaços intermediários marcados pela própria idéia de urbanidade. A suposição é de que esta cultura urbana híbrida, esponjosa e promíscua, sempre em troca e exposição, está em constante transformação, fluxo e circulação. Longe de perder ou ganhar, ela sempre se desterritorializa para se reterritorializar novamente.

Esta mobilidade das coisas, pessoas e formas simbólicas sugere que trajetórias, situações e lugares determinados produzem obstáculos que emperram processos ou que então são atravessados por estes. Aqui não há uma apologia do nomadismo, da viagem ou do urbano como o mundo da acessibilidade de recursos e oportunidades. O que se propõe é justamente mostrar como este território circulatório está prenhe de bloqueios, impasses, conflitos e fronteiras a serem trabalhadas e negociadas. E são estas travessias e intersecções que valem a pena descrever e estudar (Hannerz, 1997; Clifford, 2000). A questão é, portanto, estabelecer instrumentos metodológicos capazes de interpretar como estes vetores de territorialização se realizam, como estes eventos de mobilidade se manifestam, como estas redes de ligações se exercem umas nas outras, e como estas articulações diversas e desiguais se organizam e se estruturam no centro de São Paulo e seus territórios, a partir da questão população de rua.

É interessante notar que para Deleuze as formulações operadas por Foucault, a respeito dos dispositivos de poder, constituem-se enquanto uma cartografia. (Deleuze, 2005) Ao analisar os dispositivos, estes estados mistos de relações, seria preciso fazer um mapa que não remontasse aos pontos originários ou primordiais, mas seguisse e desemaranhasse linhas compostas, sempre agitadas, instáveis, difusas e singulares. Tarefa esta que implicaria necessariamente numa microanálise (Deleuze, 2006:109). Como os dispositivos são compostos por linhas de forças, analisá-los consiste em remontar seu diagrama, desenhar o mapa capaz de expor as relações de forças que os constituem. Para fazer uma cartografia deve-se então marcar caminhos, rastros, movimentos e seus efeitos.

O problema aqui colocado é o de atentar para o funcionamento deste dispositivo voltado à população de rua, descrevendo as formas de que se revestem algumas de suas facetas em relação à cidade. Contudo, uma antropologia preocupada em levar a sério a especificidade do urbano em suas indagações possui uma grande dificuldade para definir e delimitar uma unidade de observação pertinente (Hannerz, 1980). Assim, sabendo ser impossível apreender a totalidade dos mecanismos operantes nesta constelação de forças e instituições que gravitam em torno da rua e seus habitantes, e mesmo de apreender globalmente qualquer outro tipo de realidade social, o procedimento metodológico aqui 
proposto é, através de um trabalho de campo multi-situado (Marcus, 1995), tecer uma certa pluralidade de cenas descritivas interligadas, capazes de flagrar algumas importantes "maneiras de fazer" inerentes a este campo.

Adotar a etnografia multi-situada como procedimento metodológico implica em reconhecer a multi-localidade na experiência urbana se realiza, privilegiando, portanto, espaços intermediários da existência social (Perlongher, 1989), tais como trajetórias, eventos políticos, instituições, lugares de passagem e devires. Não mais os locais estáveis, isolados, ou outras falsas unidades, comunidades e homogeneidades. Descrever sim a multiplicidade de lealdades, as nodalidades, os agregados, as redes e os reais circuitos em funcionamento. $\mathrm{O}$ procedimento básico é perseguir etnograficamente o fenômeno população de rua e mapear suas linhas de força através de alguns acessos privilegiados. Seguir os "volteios" desta questão em suas múltiplas aparições e transações, traçando associações e conexões parciais capazes de identificar alguns importantes nós relacionais, para assim desenhar uma possível cartografia dos agenciamentos. Expor, portanto, este dilema em ação e em jogo sob diversas óticas: apresentando narrativas de seu percurso, teatros de conflitos e tensões, e situações ordinárias em instituições e equipamentos públicos.

Foi, portanto, através de jogos diferenciais e conexões parciais estabelecidas em campo, que foi possível tecer um diagrama de relações capaz de apresentar este dispositivo. Assim, o procedimento metodológico foi abordar o trabalho de campo, em suas diferentes situações, a fim de lançar luz sobre as variações existentes nas questões e nos mecanismos comuns que estavam orientando o conjunto da investigação. Foi através deste trabalho de ligação parcial entre os saberes produzidos em campo que o material de pesquisa foi estabelecendo conexões articulatórias com outros materiais etnográficos, sem nunca formar uma totalidade completa capaz de fala sobre "o" dispositivo da população de rua, mas, permitindo ser capaz de enunciar certos feixes de questões que poderiam ser colocados e questionados frente a outros.

\subsection{Roteiro da dissertação}

A proposta desta dissertação é, a partir de uma abordagem fundamentalmente qualitativa, descrever o dispositivo da população de rua em movimento e funcionamento a partir de diferentes perspectivas, de modo a não esgotar o tema e permitir a apresentação de uma certa pluralidade de elementos que compõem este campo gravitacional que passou a articular a experiência de rua na cidade de São Paulo. Ao trabalhar etnograficamente com as 
variadas escalas e perspectivas do problema, as linhas que costuram este universo tão controverso vão sendo tecidas. A proposta é descrever e analisar trajetórias, eventos e situações institucionais, buscando surpreender este dispositivo no jogo de seus variados planos de consistência, em sua estrutura de "massa folheada". Com a intenção de mostrar um conjunto de cenas descritivas, os capítulos da dissertação foram estruturados de acordo com o tipo de material etnográfico coletado e produzido. Cada um destes capítulos e materiais analisados apresenta e enfoca certos aspectos em torno do tema, de maneira que haja uma certa transversalidade de questões que podem aparecer mais numa parte que em outra. Estes capítulos devem ser entendidos como objetos etnográficos destacados de uma pluralidade de elementos que compõem o dispositivo da população de rua e devem ser entendidos como operadores funcionando no interior de jogos de sentido e força.

Cada capítulo também está dividido por partes, sendo que se inicia sempre com uma pequena reflexão a respeito do tipo de material etnográfico analisado e se encerra também com considerações mais gerais e que buscam amarrar os conteúdos discutidos em seu interior. A última parte de cada um dos três capítulos que compõe o corpo da dissertação possui em seu título a palavra "como" de maneira a enfatizar o caráter etnográfico e descritivo dos processos analisados bem como possibilitar discussões teóricas ali circunscritas.

No primeiro capítulo, proponho uma interpretação sobre o nascimento da população de rua na cidade de São Paulo a partir das narrativas e trajetórias de atores diretamente vinculados a este processo. A exposição destas trajetórias plurais e interconectadas busca apresentar uma dimensão histórica e diacrônica deste campo de relações, bem como enunciar alguns personagens e problemáticas que estarão presentes nas partes subseqüentes da dissertação.

No segundo capítulo, são contemplados eventos e rituais políticos que contestam, afirmam e colocam em cena a população de rua como uma questão pública. Estes eventos, carregados de tensões, ambigüidades e significados múltiplos, permitem explicitar articulações e processos contemporâneos no qual o fenômeno está inserido junto com uma enorme multiplicidade de coletivos, organizações governamentais, não governamentais e outras alteridades políticas. A exposição desta cadeia de eventos tem a intenção de apresentar uma dimensão mais política e pública deste fenômeno.

No terceiro capítulo, focalizo a experiência institucional e cotidiana do dispositivo. Apresentarei sucintamente as especificidades dos componentes da rede de atendimento à população de rua instalada na cidade de São Paulo e sua atual configuração. Posteriormente exponho algumas situações e impasses vividos ordinariamente no interior destas instituições. 
Este capítulo possui uma dimensão mais espacial e sincrônica do dispositivo e tem a intenção de demarcar a experiência ordinária vivida por seus usuários e funcionários.

Finalmente, à guisa de conclusão, pretendo apresentar considerações finais deste estudo. 


\section{Capítulo I: Tecendo a trama de uma história}

\subsection{Costurando trajetórias com fios da experiência}

Notavelmente boa parte dos estudos sobre população de rua dedica-se detidamente à interpretação dos processos que levaram pessoas a encontrarem-se em situação de rua. E uma metodologia comumente utilizada nestes estudos é a análise de histórias de vida. As narrativas aí coletadas revelam toda uma multiplicidade de itinerários e de circuitos anteriores à situação de rua. Estes relatos expõem um mundo inesperado de aventuras, profissões, moradias, viagens, amores, brigas, ilusões e desilusões, que permitem pôr de lado explicações homogêneas e mecânicas a respeito das causas que levaram a pessoa à rua. Devido às características extremamente contingenciais e particulares com as quais cada trajetória flui, as determinações da situação de rua são aí embaraçadas com tantos outros acontecimentos econômicos, familiares, biográficos e históricos. Contudo, nestes itinerários que transcorrem e correm rumo à rua, as similaridades capazes de articular as intrincadas diferenças residem justamente em seu aspecto negativo de perda. Prejuízo emocional e físico, estrago em casa e no trabalho. Deslocamento brusco, concreto e simbólico. O que estas heterogêneas histórias de vida possuem em comum é justamente o fato de serem histórias de rupturas, percursos de sucessivas perdas, trajetórias de exclusão (Escorel, 1999; Nasser, 2001; Frangella, 2005; Rosa, 2005). Estas biografias narradas enunciam toda uma teia de relações anteriores, mas que inevitavelmente possuem a rua como ponto de chegada: "daí, acabei na rua", "então, me vi no olho da rua", "aí fui parar na rua da amargura", "de repente, virei morador de rua". E a rua é tida aqui como fim de linha, situação-limite da qual "daí para baixo não se desce mais".

Apesar de toda riqueza que estas trajetórias podem nos oferecer, este capítulo não busca se dedicar aos percursos biográficos dos moradores de rua, apesar de eventualmente fazê-lo. A tentativa foi de intercambiar um pouco as coisas para ver o que daí pode surgir. E assim o ponto de interrogação usual foi deslocado: não mais fazer falar de si o morador de rua, mas sim fazer falar de si aquele que fala do morador de rua. No entanto, aqueles que aqui irão falar de si e suas experiências não são precisamente porta-vozes da rua, apesar de em determinadas ocasiões constituírem-se enquanto elos capazes de ligar estas vozes emanadas da rua com o espaço público da cidade. Por isso, focar nestes relatos nos ajuda a apreciar como a experiência da rua vai sendo urdida sob outros pontos de vista e olhares, bem como ganhando contornos muito particulares. 
Como na cidade de São Paulo a população de rua possui uma história própria, a aposta aqui é seguir justamente os percursos de alguns mediadores desta história. Mediadores que a agenciaram, mas que também a questionaram. A idéia é tecer a trama desta história a partir dos tempos biográficos e práticas singulares nas quais vivenciaram os atores que participaram do processo. E o processo analisado, ou melhor, o solo histórico e pano de fundo onde se ancoram e se encenam tais trajetórias é o nascimento da questão população de rua na cidade de São Paulo. Como uma questão não nasce sozinha, o desafio aqui é o de acompanhar fluxos de memória em itinerários interligados que atravessaram, envolveram e também possibilitaram o nascimento da mesma. É sob tal perspectiva que este capítulo visa contribuir parcialmente com alguns dos poucos estudos já efetuados sobre os processos históricos relativos à população de rua (Rosa, 1999, 2005; Domingues Jr., 2003; Barros, 2004).

Tal é o terreno exploratório deste capítulo: trabalhar com narrativas de trajetórias que se cruzam, para daí trançar e apreciar de perto a trama de uma história. Não qualquer história, mas sim uma história específica e, como toda, parcial. Por isso o intuito é apreender, mediante perspectivas singulares de passados compartilhados, a tessitura de historicidades plurais cujo pólo de gravitação passou a ser a rua e as questões que transitam por este universo. Um universo hoje cravejado por aparatos institucionais, técnicas discursivas e operações políticas específicas. No entanto, como sabemos, as coisas nem sempre foram assim. Este conjunto interligado de práticas são realidades recentes e que foram se assentando aos poucos à experiência urbana paulistana. A própria população de rua - atualidade indiscutível e irredutível - é algo relativamente novo, questão que foi ganhando maior coerência discursiva, consistência óptica e prática, e constituiu-se enquanto um dilema público, ou pelo menos, um dilema para um certo público. Assim, este capítulo busca contar um pouco desta história, só que não uma história abstrata a partir de algum ponto de vista que lhe seja exterior e que lhe transcenda. O desafio consiste em trabalhar com uma rede de destinos entrecruzados unidos pela lembrança de uma história partilhada, com o propósito de narrá-la de perto e de dentro, através dos atores que fizeram e se fizeram nela. No entanto, antes de falar dos atores, suas obras e, portanto, da história que será contada, faz-se necessário levantar algumas questões de ordem metodológica.

Para iniciar esta discussão, um interessante texto de Bernard Lepetit (2001) pode aqui nos fornecer idéias fecundas, cujo título já é em si mesmo bem sugestivo: A história leva os atores a sério? Neste ensaio o autor tece uma ferrenha crítica às interpretações que vêem no movimento histórico apenas o ajustamento mecânico de uma estruturação abstrata. Insiste, por sua vez, que os processos são o resultado de uma contínua interação entre uma infinita 
pluralidade de agentes. Contudo, este deslocamento efetuado por Lepetit não consiste naquilo que poderia ser (mal)visto como um simples abandono da estrutura anônima e inconsciente em direção a sujeitos supostamente voluntaristas. O que o autor quer enfatizar é a inviabilidade de se pensar numa história ausente de intencionalidades, obras e usos sociais, ainda que todos estes muitos bem circunscritos em campos de correlações de forças e situados em configurações de poder. Trata-se, portanto, não de abandonar ou elevar os sujeitos, mas sim de saber historicamente como se chega a um acordo estratégico entre sujeitos, sobre sujeitos e sobre objetos. Trata-se também de saber como este acordo se faz, fracassa e se desfaz, manifestando o dissenso mediante múltiplas formas de apresentação.

Ao focar na reconstituição cuidadosa dos horizontes espaciais e temporais dos atores, é possível apreciar ações humanas como sequiências de engajamentos sucessivos que, mobilizando competências diversas, realizam uma adequação à situação presente em constante fluxo. Deste modo, Lepetit acena para a necessidade de se pensar a história como um movimento real, assentado em práticas e situações concretas. O processo histórico é colocado aqui como um eterno presente em andamento, um presente conflitivo, controverso e carregado de impasses e competências variáveis, no manuseio do tempo passado e nas redefinições dos rumos futuros. Aproximar-se dos atores em ação permite também jogar luz sobre o engajamento na experiência ordinária do citadino, bem como nas modalidades de reutilização das formas urbanas passadas. Ao se colocar o processo histórico na perspectiva dos atores, é possível ver como se instauram “dispositivos novos que são ao mesmo tempo o contexto de elaboração, o ponto de ancoragem e uma das condições da eficiência das novas normas" (Lepetit, 2001:236). Contudo, há várias maneiras de se levar a sério os atores numa dada história e aqui serão privilegiadas trajetórias entrecruzadas, nas quais estes se envolvem e das quais são o resultado.

Sabe-se que a categoria de trajetória evoca um movimento temporal no espaço, apresentando a operação de unidade numa sucessão diacrônica de pontos percorridos. Não se limita, portanto, a uma sequiência de posições num espaço dado. A trajetória implica necessariamente numa alteração temporal, simultaneamente sua e dos elementos que a envolvem. Ao mesmo tempo em que se desloca, adquirindo ritmo e intensidade própria, a constelação dos laços que a constituem também se transforma (Grafmeyer, 1995). Apesar de esta noção restituir parcialmente a margem de manobra dos atores, a trajetória não é uma sucessão de decisões livremente tomadas ao sabor de suas preferências e desejos, tampouco uma imposição totalmente estruturada. Mas a questão que se coloca aqui não é, como pode parecer à primeira vista, sobre o grau de determinação ou liberdade que os atores sociais 
foram construindo ao longo de sua existência. Seguindo as sugestões de Grafmeyer (1995) e Levi (2005), a atenção descritiva se deterá, sobretudo, sobre o sentido que tais operações em deslocamento adquirem em relação a outras formas de mobilidade e ao longo dos processos interdependentes. Ao analisar de perto estas trajetórias enlaçadas, o esforço é apreciar a maneira como aquela poeira ínfima dos acontecimentos ordinários vem a ser sedimentanda, alterando, ganhando substância e transformando-se em referência para devires e processos futuros ${ }^{12}$.

Contudo e apesar de tudo, permanece o problema da unidade evocada na idéia de trajetória, como se os sucessivos tempos e espaços fossem atravessados por um mesmo agente e não por um movimento sujeito a infinitas transformações e metamorfoses. E esta unidade evocada na noção de trajetória adquire sua mais explícita puerilidade no nome próprio, um suporte de multiplicidades que pode se manifestar tanto no nome de uma pessoa, de uma coisa ou de uma coletividade qualquer. O nome próprio, como mostra Pierre Bourdieu, é um "designador rígido", um ponto fixo num mundo que se move. E assim, falar de histórias de vida é "pressupor que a vida é uma história" (Bourdieu, 2005:183). E aqui reside uma de suas principais críticas ao uso de trajetórias, pois, para Bourdieu não seria possível compreender uma trajetória sem um conhecimento prévio dos estados mistos e sucessivos do campo no qual ela se desenrolou e, logo, do conjunto das relações que uniram o agente considerado ao conjunto dos outros agentes considerados. Em suas palavras "quem pensaria em evocar uma viagem sem ter uma idéia da paisagem na qual ela se realiza?" (Bourdieu, 2005:190). Assim sendo, o desafio aqui proposto é menos evocar uma travessia sem ter em conta o terreno que esta cruza, e mais evocar um campo irregular, tendo por lastro trajetórias que o atravessam. Ao focar nos percursos individuais e por vezes coletivos, a intenção é ver como estes itinerários entram em cena, organizam espaços para práticas e abrem todo um campo de ação. Para retomar a metáfora de Bourdieu, a idéia é descrever como esta paisagem é em verdade composta por múltiplas viagens.

Entretanto, renunciar ao simulacro da integridade unitária (de indivíduo ou grupo) permanece como um empreendimento no mínimo complicado. As considerações de Bourdieu sobre enclausurar a existência social em busca de uma improvável unidade de sentido revelam uma ingenuidade imperdoável nos usos das trajetórias, ainda mais porque, neste século, a

\footnotetext{
${ }^{12}$ A noção de sentido aqui citada de maneira alguma se remete a uma teleologia histórica ou curso temporal prédeterminado. Pelo contrário, vincula-se às intrincadas e insuspeitáveis direções nas quais os processos vão sendo canalizados e desviados no decorrer do infinito e indefinido jogo das relações sociais. E é na pluralidade e instabilidade imanente de tais processos que os sentidos dos deslocamentos, aqui interrogados, vão sendo construídos.
} 
literatura não cansou de revelar a natureza descontínua e provisória do real (Clifford, 2002; Loriga, 1998). É por isso que os nomes, estes designadores pouco ou muito rígidos, aqui manuseados (e suas supostas unidades evocadas) terão como ancoramento justamente a experiências dos atores. Trata-se de levar a sério as narrativas, suas elaborações e construções de sentido, bem como as classificações êmicas articuladas. Através das narrativas, os atores exibem mundos sociais pelos quais passaram, apresentam enredos de travessias, expõem jogos de linguagem e revelam categorias culturais disponíveis no meio que circulam. Em verdade o próprio relato é uma trajetória, nos diz Michel de Certeau (1982). Trata-se de um tipo de travessia em um campo de relações, um modo de tratamento, inserção e exposição destas relações. As potencialidades humanas fluem sobre a realidade também pelas fissuras abertas pelas palavras. As narrativas, diz de Certeau, antecedem as próprias práticas sociais no sentido de abrir um campo para elas. A oralidade do relato se insinua, sobretudo, como um desses fios na trama de uma interminável tapeçaria, que pode e deve ser, utilizada na economia escriturística. Como é a narrativa que organiza discursivamente o campo de prática dos atores, na medida em que o relato diminui, o espaço de relações da experiência se torna cada vez menos visível. E é por isso que a presença das narrativas é importante: elas revelam práticas e são em si mesmas práticas. Mais do que descrever golpes, elas o fazem (de Certeau, 1982).

Como uma maneira de acentuar as variações existentes nas trajetórias, uma estratégia aqui utilizada é enfatizar e focar nos pontos de inflexão e intersecção com outras trajetórias e outros eventos. Vera Telles, ao discorrer sobre o uso de trajetórias urbanas, atenta para a importância de se refletir mais detalhadamente sobre estes entroncamentos, aquilo que chama de eventos de mobilidade: "pontos críticos, pontos de inflexão, de mudança e também de entrecruzamento com outras histórias - 'zonas de turbulência' em torno das quais ou pelas quais são redefinidas (deslocamentos, bifurcações) práticas sociais, agenciamentos cotidianos, destinações coletivas" (Telles, 2006:70). Seriam estes pontos, nodalidades plurais da experiência social, que permitiriam colocar os processos urbanos e históricos sob perspectiva, flagrando como tais percursos conectam e se conectam em pontos de condensação e pólos de tensão múltiplos. Estas curvaturas, mudanças e passagens ambíguas, que se fazem presentes nas narrativas, constituem-se como momentos especiais de interrogação sobre o modo pelo qual as diferenças enunciadas são articuladas numa ordem de sentido atribuída pelo próprio narrador.

Assim, narrar é conferir sentido e ordem ao mundo que se vive e no qual as palavras são lançadas. Uma narrativa possui uma estrutura que convém sempre considerar, e tal 
ordenamento discursivo é justamente aquilo que permite estabelecer significado aos diferentes fragmentos do relato. Suas diversas partes permitem encaixes, todo conjunto do enredo possui um certo encadeamento que vale analisar, principalmente ao se considerar e reproduzir apenas parte do texto oral (Kofes, 1994). É por este motivo que a criação de uma imagem de si e de outros não pode ser interpretada como um problema ou empecilho para a análise das trajetórias. São estas expressões, manifestas por uma infinidade de titulações e nomes próprios, que permitem um uso analítico da narrativa e a constitui como um enredo dotado de ordem e sentido. Não se trata, então, de descrever subjetividades alheias. A idéia é que tais subjetividades falem sobre si mesmas e de outras, e que estes registros narrativos forneçam o lastro descritivo para a construção de um texto capaz de contar uma história, que reintroduz permanentemente as regras do jogo no próprio relato do jogo (Revel, 1989a). O foco da exploração também não é decifrar os atores e aquilo que supostamente residiria por trás de seus relatos, mas compreender os sentidos e as causalidades presentes no interior de suas elaborações discursivas. As narrativas não serão tratadas em nome de outra coisa que não elas mesmas e seus cruzamentos imanentes com outros elementos. Também não será suposto que por trás destas histórias existam segredos ocultos, cujo progressivo desvelamento faria aparecer. Antes de qualquer forma de crítica, trata-se de ouvir o que os atores têm a dizer e, assim, preocupar-se mais com as contribuições que enunciam e deixam entrever do que com os supostos limites de suas afirmações. Esforçar-se para entender o dito como dito, portanto.

Já se disse várias vezes que oralidade é quente e a escrita é fria. Por isso a passagem de uma ordem verbal para uma não-verbal é sempre um assunto um tanto complicado de se lidar. A fala é um ato carregado de ambigüidade. Lança ao mundo palavras moldadas e ajustadas à situação de interlocução, signos enunciados que se deslocados do plano comunicativo no qual foram criados podem adquirir significados outros. Justamente por ter sido arquitetada no preciso instante da conversa é que a oralidade é quente, instável e fugidia. Carrega consigo trejeitos, correspondências e sentidos tácitos urdidos no fugaz processo interacional. Por sua vez, a escrita busca registrar, demarcar. Ela tenta estabilizar no texto um mundo fluido de ações verbais e operações lingüísticas plurais. A economia escriturística, nos diz de Certeau (2003), é uma prática mítica moderna, um sonho visionário do universal que consiste em construir um texto unívoco que tem poder sobre a exterioridade da qual foi previamente isolado. A tradução do texto oral para o escrito é, portanto, um momento delicado de intensa negociação, seleção e valoração. Momento nada neutro e que pode fixar na lápide fria da página em branco apenas uma faceta reduzida (e por isso mesmo redutora) do contraditório signo que foi capturado no meio da corrente verbal, no agitado ato da fala. 
Então como escrever uma história do sucessivo fluxo presente através de uma escritura que, de uma maneira ou outra, tende a estabilizar, fixar e esfriar tudo aquilo que foi dito e feito no calor do instante? Uma pergunta interminável para uma resposta inalcançável e, apesar disso, perseguida.

Para composição deste capítulo, foram privilegiadas narrativas de personagens conhecidos e conhecedores do universo de relações que gravitam em torno da rua. Não por acaso seus relatos citam outros atores e outras trajetórias, conjugando uma verdadeira rede de inter-reconhecimento. As pessoas entrevistadas obviamente possuem um conhecimento muito maior que o meu acerca daquilo que perguntei. E o que me ajudou nestas conversas foi o fato de conhecer um pouco da linguagem travada, ser conhecido entre tais personagens, bem como saber um pouco das histórias singulares destes narradores antes do momento da entrevista. Várias outras anotações de campo, escutas, conversas e narrativas registradas neste meio (e que não aparecerão aqui) também serviram como base e referência de apoio para a construção das trajetórias. Igualmente outros documentos, livros e estudos foram utilizados de maneira a situar melhor tais itinerários no tempo e no espaço da cidade. Contudo, como já foi afirmado antes, as narrativas são os principais lastros que tornaram possível navegar por estes percursos sociais que conectam diferentes coletividades, pessoas e lugares.

Assim, um conjunto de entrevistas não estruturadas foi efetuado e as narrativas aí produzidas foram, então, gravadas e transcritas. Com exceção de uma, todas as conversas se realizaram nos locais de trabalho e atuação dos narradores. O pretexto do encontro foi explicado com antecedência à ocasião e, no momento da entrevista, o motivo do estudo foi mais bem detalhado. O tempo das entrevistas variou desde uma hora e meia de conversa, até mais de três horas. E, também, por este motivo, algumas trajetórias renderam descrições e travessias mais elaboradas que outras. O diálogo foi conduzido da maneira mais aberta possível (levando em consideração às condições específicas), visando que os locutores pudessem construir e formular suas narrativas e experiências vinculadas à rua da maneira que melhor lhe aprouvessem. A pergunta inicial, e que serviu como parâmetro de diferenciação em todas trajetórias, era: “como você foi parar na rua?" A interrogação comumente feita aos moradores de rua foi então posta para aqueles que trabalham e engajam-se diariamente com a questão. Não por acaso, as diferentes formas de recrutamento e o sentido dos deslocamentos efetuados nesta constelação de proximidades e distâncias são alguns dos eixos principais na descrição dos percursos. De maneira geral, pode-se dizer que o fato de possuir algum conhecimento anterior sobre os narradores facilitou o acesso a eles, a flexibilidade na 
conversa e também a construção de um certo inventário de questões anteriores sobre suas trajetórias.

Os relatos aqui inseridos no corpo do texto não foram pensados como apêndices, mas sim como parte dele. Estes trechos nos ajudam a compreender como o contexto é significado discursivamente pelos atores. Texto e contexto, pois, se articulam neste capítulo. No entanto, mesmo inserindo no texto apenas curtos trechos das narrativas coletadas, o processo de tradução entre oralidade e escrita obriga certas alterações que valem ser rapidamente apontadas.

Todas as narrativas aqui coletadas são repletas de marcadores conversacionais tais como: “né?”, “então”, “assim”, “sabe?”, “entende?”, “aî”, “bom”, “olha”. Alguns exprimem o início de um assunto, outros são seqüenciadores dos processos e elementos narrados, mas todos possuem a função de ligação entre os componentes discursivos, ou então explicitam a prática interlocutória de modo a repor constantemente o acordo tácito, dos significados mobilizados, no interior do diálogo. Assim, estes marcadores não são elementos residuais numa narrativa oral, mas são justamente aquilo que permite dar coesão e coerência ao texto falado. Eles enriquecem a narrativa, articulam os termos descritivos, põem ritmo e cadência ao relato, além de servir como conectivo entre a enorme multiplicidade de funções mnemônicas mobilizadas. Marcadores são procedimentos exclusivos da língua oral, eles revelam as condições de produção do texto oral. Não por acaso, em nossa cultura escrita é precisamente a ausência destes marcadores que gera a impressão de veracidade aos discursos (Barthes, 1986). No entanto, como este é um texto escrito, optei por eliminar as repetições e os longos momentos de pausas, bem como cortar o excesso dos marcadores, deixando apenas aqueles que tinham uma função interna ao trecho reproduzido.

Apesar de inegavelmente haver certos aspectos biográficos nas trajetórias aqui expostas, a idéia não é compor um mosaico de histórias de vida. Até porque nos relatos registrados se privilegiaram muito mais as conexões próprias ao campo social analisado do que relações outras. Questões mais familiares e privadas não foram suscitadas no momento conversacional, mas, no entanto, apareceram. Assim as relações familiares, apesar de serem elementos fundamentais na configuração de trajetórias (Cabanes, 2006), foram assinaladas apenas nas narrativas que enunciaram tais relações. Outro elemento que distancia as biografias das trajetórias aqui analisadas é o fato destas últimas não se restringirem aos indivíduos, apesar de tê-los como importantes balizas. Inclusive porque os percursos pessoais aqui presentes comumente se mesclam e, algumas vezes, até mesmo se dissolvem narrativamente com outros modos de ação, podendo figurar como trajetórias temporárias de 
grupos, agrupamentos e desagrupamentos. Estas formas de associação e dissociação, nas quais os personagens se envolvem, são aqui tratadas como coletivos transitórios e não como entidades sociais inalteráveis. Alguns destes coletivos podem possuir mais plasticidade que outros, porém todos estão submetidos às alterações do tempo e do espaço. Assim, o importante nestes percursos analisados não são os atores em si e sim os vínculos que estes ativam, as ligações que exercem e as relações que engendram e estabelecem com outras formas de mobilidade. E neste diagrama de interdependências, que vai se estendendo e se complexificando ao longo das micro-histórias narradas, não há, como se verá, repetição, mas sim, diferença. Estas trajetórias e a multiplicidade de suas situações permitem apreciar de perto as infinitesimais ramificações relacionais, bem como a produção e apropriação de saberes singulares, distribuídos irregularmente pelo campo social. E deste modo, nos entrecruzamentos destas conexões, variações contínuas se realizam e se apresentam como matrizes de transformações (Foucault, 2001c:94).

Todas as trajetórias aqui presentes estão, de diferentes maneiras, profundamente vinculadas a este meio. De tal modo que, como veremos, seus percursos misturam-se com a própria constituição deste dispositivo de ligações adensado no centro de São Paulo. Estes personagens são importantes referências na criação de saberes e poderes próprios à população de rua. Também foram e são atuantes no conflituoso processo de construção da imagem pública desta população enquanto um sujeito de direitos, bem como no questionamento e agenciamento dos aparatos institucionais voltados a este contingente. Além disso, armazenam consigo uma memória desta história, memória que será aqui explorada em suas diferentes ramificações e interfaces. A escolha destes atores se deu pelo fato de todos serem importantes mediadores neste universo, operadores de conexões entre o mundo da rua e outros mundos sociais urbanos. Ao narrar suas trajetórias enlaçadas em outras trajetórias, estes narradores vão traçando conexões heterogêneas e parciais, que atravessam e ao mesmo tempo permitem vislumbrar a instalação deste dispositivo que foi historicamente envolvendo a população de rua, constituindo-a enquanto foco de múltiplos agenciamentos urbanos. E neste processo narrativo, intrincados elos vão sendo tecidos entre mundo da rua, igrejas, organizações de trabalho, meios de comunicação, órgãos estatais, autoridades públicas, formas institucionais, leis e movimentos sociais. Há uma multiplicidade de elementos discursivos que podem entrar em táticas e estratégias diferenciadas e que desempenham papéis variados no interior deste campo social. É essa distribuição de fluxos e posições que é preciso recompor. Justamente por serem atores que participaram e participam, de diferentes maneiras, da disputa social pela 
definição e pelo reconhecimento público da situação na qual vive este contingente populacional, é que são importantes.

\subsection{Na Periferia do Centro}

Comecemos então de um início. Não da origem de onde tudo começou, mas de algum início possível. Como nenhuma questão nasce sozinha, iniciemos nossa exploração por ali, onde as coisas ao menos começaram a dar as faces, ainda que sob formas residuais e pequenas, misturadas com outras questões e através de diferentes nomes. E poderíamos iniciar esta exploração revisitando um tempo em que a cidade de São Paulo começava a aparecer como um objeto de decifração intelectual e política, a década de 1970, importante momento de nossa história, no qual pesquisadores passaram a se dedicar aos estudos dos processos urbanos com maior afinco e que toda uma heterogeneidade de formas de mobilização popular inovaram práticas de luta política, em prol de direitos recém descobertos ${ }^{13}$. É aqui que talvez possamos situar a emergência dos primeiros e pequenos contornos estabelecidos que, aos poucos, começaram a delimitar uma certa especificidade em relação ao universo da rua e seus personagens. E as modalidades iniciais de entendimento e intervenção neste universo aparecem na cidade de São Paulo, de maneira muito bem circunscrita e localizada.

Estes contornos práticos, que aos poucos vão balizando referências para as pessoas ligadas à rua, começam a ser trabalhados microscopicamente no interior de um grupo de religiosos no centro da cidade. São as Oblatas da Fraternidade de São Bento e seus colaboradores que inauguram estes modos de ação, modalidades próprias de conhecimento e prática que passam a tentar dar forma e corpo a esta pluralidade de experiências até então dispersas. Este grupo de religiosos compunham uma organização chamada OAF (Organização do Auxílio Fraterno), fundada em 1955 e cuja procedência remonta a práticas católicas e humanistas efetuadas em Montevidéu, Uruguai, e cujas atividades de caridade ao longo de sua trajetória foram se deslocando para aqueles que, até então, eram vistos como os "abandonados" e "marginais" do Centro. Não obstante, é necessário ter em conta que os

\footnotetext{
${ }^{13}$ Nota-se que esta constituição da cidade enquanto alvo de disputas e de pesquisas possui uma dimensão histórica e política inegável. Os processos que se viram efetuados nos anos pós-64 em São Paulo possibilitaram uma importante transformação dos pressupostos gerais que orientavam as condutas em relação ao fenômeno urbano. Vemos que entre toda a mobilização política e religiosa, que se viu durante a década de setenta em São Paulo, e as pesquisas científicas então iniciadas, existiram importantes correspondências. Talvez a mais conhecida e que explicite mais o caso em questão é a pesquisa sobre as condições de vida dos trabalhadores paulistanos encomendada pela Comissão Justiça e Paz da Arquidiocese de São Paulo, que resultou no livro São Paulo, 1975: crescimento e pobreza (Kowarick et alii, 1976), e que serviu como importante arma política na luta pela reivindicação dos direitos da classe trabalhadora urbana.
} 
participantes da OAF, composta tanto por leigos quanto por religiosos, sempre se viram muito mais como integrantes de um Movimento Cristão e de uma verdadeira Missão (uma prática missionária voltada aos mais destituídos) do que propriamente como membros de uma ONG ou uma organização filantrópica.

$\mathrm{Na}$ passagem para a década de oitenta, a trajetória deste coletivo passa por uma importante inflexão, radicalizando suas práticas e redefinindo seu campo de ação, agora, em direção ao "povo sofrido e sem casa da região central". Neste período, escrevem conjuntamente um livro, intitulado Somos um povo que quer viver, que só é publicado em 1982. Esta obra, espécie de testemunho-relato das experiências e da transformação na qual a organização passou, é feito na "esperança de que outros conheçam e também se comprometam" (OAF, 1982:8) ${ }^{14}$. Este livro também explicita o deslocamento coletivo para uma nova causa de ação, estabelecendo, assim, os contornos e as formas iniciais sobre uma realidade que até então era informe:

Quando pensamos nos pobres como povo, nos vem à idéia o povo situado na periferia da cidade. Na nossa missão, porém, o povo faz parte de uma periferia especial; sua demarcação não é geográfica, mas sociológica, é "a periferia do centro”. Aqui, os pobres não são notados, sua presença está escondida. A simples vista não percebe que atrás da porta de uma antiga mansão mora, talvez, uma centena de pessoas, nem que outras centenas de homens e mulheres transitam pelas ruas, sem destino (OAF, 1982:97).

Este trecho, retirado da citada obra, atesta uma preocupação com uma figura da pobreza que até então permanecia invisível aos olhos da época. É aquela pobreza situada na "periferia do centro" e são os personagens que habitam este mundo de relações que ao longo dos anos irão se colocar sobre o cruzamento cerrado de incessantes e múltiplos agenciamentos urbanos, cada vez mais especializados. E neste processo, as discursividades, os pequenos saberes e as minúsculas experiências construídas e formuladas no bojo das relações entre este grupo religioso e os "marginais" no centro começam a circular e a se distribuir no interior de uma rede mais ampla de instituições, adquirindo um importante papel no desenrolar desta história. Tais referências discursivas passam, aos poucos, a serem manejadas por outros

${ }^{14}$ A trajetória e a experiência de trabalho da OAF está registrada em dois livros organizados pela principal condutora destas Oblatas, que atendia pelo nome de Nenuca. Estes dois livros - cujos títulos são Somos um povo que quer viver (OAF, 1982) e Quantas vidas eu tivesse, tantas vidas eu daria (Castelvecchi, 1985) - possuem o caráter de um testemunho religioso e de vida, e foram escritos na passagem dos anos setenta para os oitenta, um pouco antes da morte da autora. Ambas as obras contam com depoimentos de muitas outras pessoas que participaram da $\mathrm{OAF}$ e que inclusive estarão presentes nas trajetórias aqui expostas. Estes livros são importantes fontes documentais utilizadas na primeira parte deste capítulo. 
atores, em outros contextos e situações, alterando-se e adquirindo maior intensidade e consistência prática no interior de uma matriz histórica de transformações.

Além de ter sido a principal referência no momento da criação de novas práticas políticas de atendimento a esta população pobre vinculada à rua, foi também através da experiência gerada nas relações da OAF, que se estabeleceram parâmetros iniciais para novas formas de reconhecimento e de enunciação pública destes agora sujeitos. Assim, na história do nascimento da questão população de rua, é inevitável não contar parte da trajetória da OAF, suas transformações e inflexões, de como este grupo de Oblatas foi parar na "periferia do centro" de São Paulo e de como se encadeou, daí em diante, toda uma trama de mediações com outras questões, outros poderes, novos atores e novos desdobramentos, redefinindo o jogo das forças atuantes ao longo dos entrecruzados e plurais percursos temporais. E neste processo de reconstituição, a escuta atenciosa de algumas narrativas situadas em trajetórias singulares e interconectadas nos permite colocar a trama desta história em perspectiva. Comecemos, então, com a mais antiga das Oblatas ainda viva.

\subsubsection{Irmã Fortunata ${ }^{15}$}

Fortuna, como também é chamada, no momento em que nos encontramos para a entrevista, tinha 77 anos de idade, atestando ser minha informante com a maior extensão temporal de vida e memória. Nasceu no final da década de 1920 no sertão de Pernambuco, em uma pequenina cidade chamada Floresta. De família grande e muito pobre, passou toda sua juventude no semi-árido nordestino. Dada a situação de pobreza em que se encontravam, era muito difícil conseguir recursos de vida para toda a família. Tudo que ali se tinha, eram eles mesmos que faziam ou plantavam. Vida na roça, vida dura. Contudo, Fortuna insiste no fato de nunca ter passado fome. E sua parentela era extensa, composta por seus pais, tios, avós e seus muitos irmãos. Até hoje Irmã Fortuna não enxerga de um olho, resquícios de tempos passados. Quando era pequena, numa destas brigas corriqueiras entre crianças, xingou sua irmã e esta jogou um pedaço de pau que acabou ferindo seu rosto e seu olho. "Foi sangue para todo lado". E foi assim que Fortuna conheceu a capital do estado: numa consulta médica. Posteriormente estudou em escola católica até a quarta série, pois não havia anos mais avançados naquela região interiorana do estado. Fortuna narra que, desde pequena, se interessava pela religião e durante toda a conversa o tema da religiosidade vai aparecer como

\footnotetext{
${ }^{15}$ Fortunata Novaes Gominho foi entrevistada em 18/10/2005.
} 
uma constante em sua vida de diversas maneiras, inclusive como uma presença permanente desde seu início. "Sempre tive vontade de ser freira, mas como papai não deixava, eu não contava para ninguém”. Já no final da década de 1940, quando se muda para Petrolândia, cidade também do interior pernambucano, torna-se a primeira professora da colônia agrícola em que sua rede familiar começa a viver e trabalhar. Mais tarde, quando toda família vai para Recife, Fortuna começa a fazer parte do coro da Igreja e conhece Padre Ignácio.

A narrativa de Fortuna aponta o encontro com este padre como aquilo que permite a abertura para um mundo diferente daquele que até então conhecia. Padre Ignácio, sacerdote oriundo de Montevidéu e que pregava idéias muitos peculiares sobre como ter uma vida religiosa junto aos pobres, havia sido capelão do hospital do Brás em São Paulo e membro fundador da OAF. Além disso, encontrava-se sempre próximo às irmãs da Ordem de São Bento, que além de não vestirem hábitos, eram comprometidas e desenvolviam atividades não muito convencionais com os "mais abandonados". Atividades não muito convencionais porque, na época, freiras e mulheres religiosas não costumavam andar junto com certas classes de pessoas, tais como prostitutas, mães solteiras e crianças de rua. Estas irmãs eram chamadas de Oblatas e diziam dedicar-se incondicionalmente aos mais pobres e necessitados. Este nome "Oblatas", que significa "oferecidas" e "vida em ofertório a Deus", como Irmã Fortuna nos explica, sempre trouxe problemas para estas irmãs, pois em algumas ordens religiosas tal titulação refere-se a leigos agregados apenas à ordem religiosa e não necessariamente a irmãs com voto de castidade, pobreza e obediência, como era o caso destas.

Padre Ignácio, que então tinha sido nomeado capelão da igreja matriz de Recife, fazia pregações que afetavam muito Fortuna e estimulavam-na a uma série de pensamentos. Além dos discursos religiosos que catalisavam processos de subjetivação, as Oblatas, que tinham vindo de São Paulo para Recife junto com este Padre, chamavam constantemente Fortuna para trabalhar junto a elas. Então, depois de muitos convites recusados e vontades contidas, Fortuna começa a acompanhá-las, mas neste processo encontra muitos empecilhos. Naquela época, uma moça de família, como Fortuna, de maneira alguma poderia andar naquele meio que as irmãs então trabalhavam.

Tudo mulher solteira, mãe solteira, criança sem pai. Freqüentar aquela região era muita promiscuidade. Não que fosse, mas para a época era, para minha família era. Mesmo que fosse só para ficar com elas, ajudando, costurando roupas, conversando e cuidando das crianças. Minha família não podia nem imaginar. Não dava para eles saberem que eu trabalhava com as prostitutas. Papai era muito sério, nem pensar uma coisa dessas. Só uma 
amiga minha sabia que eu trabalhava com as Oblatas, lá naquele bairro mal falado. Era a zona do cais, imagina, bairro das mulheres e prostitutas. Nem minha família, nem ninguém me entenderia.

Aos poucos vai se identificando mais com o trabalho. Vai aprendendo e gostando cada vez mais do que faz. Começa a pensar em virar Oblata também, mas o problema maior é a família e, em especial, "papai que não gostava de filha moça ser freira". Seu pai, figura forte e muito presente no início de sua narrativa, achava "um desperdício essa coisa de menina freira" e "dizia para todo mundo que mulher nasceu foi para casar". Deste modo, Fortuna tinha que desenvolver suas atividades (e vontades) de maneira que sua família não percebesse. Com o tempo, foi se envolvendo mais com as atividades das Oblatas e passou a escrever constantemente para Nenuca, Oblata que vivia e trabalhava em São Paulo. Fortuna aos poucos vai pondo-se em dúvida, "não sabia o que fazer", e neste processo sua narrativa apresenta uma trajetória bifurcada. De um lado, a família e o projeto de vida programado para ela. De outro, toda aquela "aventura que era viver com Deus e com os pobres". Então, depois de muitas cartas, reflexões e conversas com Nenuca e Padre Ignácio, Fortuna se decide por fazer os votos para entrar na Fraternidade de São Bento, da qual as Oblatas faziam parte. Só que diz para Nenuca que uma condição para isso é que não poderia permanecer em Recife, só iria trabalhar com os pobres se fosse em São Paulo, bem longe da família:

Falei para ela: "Minha família vive aqui e não vai aceitar de jeito nenhum que eu trabalhe com gente mais marginal, assim, com menino de rua e prostituta." Papai não ia aceitar de jeito nenhum, ele não ia deixar isso. Mas eu queria e como é que fica? Aí fiz meus votos, sem minha família saber.

Irmã Fortunata, aos 39 anos de idade e não sendo mais uma menina, faz seus votos escondidos da família. Pretendia ir para São Paulo trabalhar com os pobres, mas não sabia muito bem quando e nem como. Até que um dia um outro Padre, que era muito amigo de sua família e sabia de toda história, comenta com uma pessoa logo após uma missa: "essa aí está se despedindo da gente". O único problema é que a cunhada de Fortuna ouve o dito e fica sabendo daquilo que até então era segredo:

E aí? O que que aconteceu? Foi a maior confusão. Justo no dia que meu pai fez bodas de ouro, toda família ali, num almoço grande e com a mesa cheia de gente, minha cunhada solta 
que eu estava indo embora. Falou: "vamos aproveitar o almoço porque a Fortuna está se despedindo da gente”. Foi uma confusão, briga danada. Todo mundo bravo comigo. Meu pai, então, nem se fala. (...) Aí depois daquilo tudo não tinha nem como ficar lá (em Recife).

Fortuna só chega em São Paulo em março de 1968, quatro anos depois da morte de Padre Ignácio em Pernambuco. E esta chegada é um choque para ela. Vemos aqui uma importante virada em sua trajetória. Não só por sua chegada na cidade grande, coisa que ela mesma qualifica como produzindo um "impacto" em sua vida, ou mesmo pelo tipo de pobreza que começa então a ter de lidar, cuja magnitude é deveras maior do que em Recife. A principal dificuldade percebida por Fortuna neste novo caminho que sua vida começa a trilhar é o estranhamento produzido em relação aos homens:

Foi difícil chegar aqui em São Paulo. Fiquei perdida, não achava os lugares para onde tinha que ir. Tinha muito barulho, era tudo muito grande. Mas quando eu entrei na Oficina São Bento (da OAF), vi aquelas caras todas, fiquei assustada. Vi todos aqueles homens e quis chorar. Chorei até. Nunca tinha ficado com homens, só com mulheres e crianças. Era um monte de homem perto de mim, estavam olhando para mim.

E este estranhamento com a diferença de gênero, Fortuna só aprende a lidar com o tempo. Quando chega em São Paulo, Nenuca logo a manda trabalhar numa fábrica, que para sua sorte, é uma fábrica de mulheres. A experiência operária era uma vivência constantemente pregada e que fazia parte das regras de aprendizado das noviças da OAF. Esta doutrina era muito forte entre elas e não por acaso o primeiro nome das irmãs de São Bento tinha sido "Oblatas operárias", só depois é que mudou. Só que para Irmã Fortuna, que sempre teve uma vida mais provincial como professora ou responsável pelos afazeres internos da casa da família, trabalhar numa grande indústria de tecelagem não era uma coisa muito fácil de se fazer. Além disso, ninguém na fábrica sabia ou podia saber que ela era religiosa. Uma das recomendações do aprendizado das noviças junto com a classe trabalhadora era justamente a de se colocar como igual. "A gente tinha de trabalhar e se apresentar como cidadão comum. Tinha que ter uma certa postura, não falar besteira, nem brigar com as outras mulheres". Trabalha então um ano na fábrica e só quando estava saindo do emprego é que conta que era freira para sua chefe, uma mulher que, segundo Fortuna, era muito autoritária e rígida com ela. 
Após este período de "formação" junto com as trabalhadoras, Fortunata começa a dedicar-se mais diretamente às práticas desenvolvidas pela OAF e estas eram voltadas aos "marginais", termo este amplamente utilizado na época. Isso era em parte decorrente das vigentes teorias da marginalidade social como maneira de qualificar, entre outras coisas, a enorme massa de desempregados e trabalhadores que então se colocavam "à margem" do mercado (Berlinck, 1977) e da própria cidade em suas precárias condições de moradia (Perlman, 1977). Independente da multiplicidade de concepções que estavam inscritas no uso do termo, é importante ressaltar que sua utilização, ao operar uma importante diferença entre "marginalidade" e "criminalidade", passa a manuseada por outros atores sociais tais como sindicatos, organizações populares e pela própria Igreja Católica. E é com este público "marginal" e "abandonado" que Fortuna passa a trabalhar mais diretamente agora, quando se muda e vai viver junto com as outras Oblatas num cortiço localizado no bairro do Brás.

Apesar de serem bem recebidas pela vizinhança, também havia muita desconfiança em relação àquelas moças. Todas muito bem católicas e educadas. Por que saíam bem cedo e voltavam tão tarde? Porque não se casavam? E nestas relações de vizinhança, as Oblatas se negavam a se apresentar como freiras, eram "moças da OAF". Segundo Fortuna, morar ali correspondia a uma tentativa de "convivência mais autêntica e missionária entre o povo pobre". É neste período que Fortuna passa a ficar mais próxima e fornecer apoio direto “àqueles que não tinham para onde ir na cidade”. De manhã até à noite trabalha junto com "os mais miseráveis". As Oblatas começam a vender doces, balas e cafezinho de maneira a interagir com os adultos e "conquistar a meninada das ruas". Neste processo de imersão nas ruas, viadutos, cortiços e ocupações, as Oblatas vão descobrindo a existência de todo um mundo "marginal" de relações no centro da cidade. E esta descoberta se faz justamente no auge do "milagre econômico", quando a população urbana brasileira, pela primeira vez na história, ultrapassava a metade da população nacional. Era uma época em que a grande questão que se impunha era a da migração.

Diariamente inúmeras famílias saíam do campo e se colocavam "a caminho da cidade" (Durham, 1985). E neste deslocamento, antigas formas de sociabilidade eram colocadas em cheque, alterando-se parcialmente. Algumas práticas e relações sociais tradicionais reterritorializavam-se na crescente periferia da cidade, através de loteamentos freqüentemente ilegais, mutirões e auto-construções de casas próprias, constituindo tudo aquilo que posteriormente a literatura especializada tratou de detalhar e descrever chamando pelo nome de "padrão periférico de crescimento urbano" (Kowarick, 1993). Entretanto, nem todos aqueles que se colocavam a caminho da cidade realizavam em São Paulo o tão esperado 
projeto de vida. E foi com alguns destes desterritorializados em relações variadas que Fortuna e outros participantes da OAF começaram, então, a trabalhar na região central da cidade.

Imaginava-se que nestes "que não deram certo" e estavam dispersos pelas ruas do centro, fosse possível não só encontrar a presença de Deus, mas também, encontrar entre eles o Povo de Deus. E nesta expectativa é que se desenvolvia o trabalho diversificado das Oblatas, como a Ronda Noturna e a Oficina São Bento:

Na Ronda a gente saia à noite na rua para levar lanche e conversar com as pessoas. Tinha café e às vezes sanduíche. Levava sempre o violão. Este era o trabalho que (eu) mais gostava de fazer. Aí a gente ficava lá. Falava do Evangelho. Conversava, violão, as músicas, o canto. Tinha gente sem documento, sem nada, sem trabalho e sem coisa nenhuma. Sem para onde ir. (Pessoas) que estavam na rua sem lugar para dormir. Aí a gente ficava lá.

Perg.: Mas que tipo de coisas vocês faziam lá?

Tudo isso. A gente falava de Deus com as pessoas. Ficava com elas. Chamava para trabalhar na Oficina (São Bento) e nos lugares. Trabalhar nas fábricas. De dia tinha plantão lá na Oficina, aí eles vinham da rua e a gente explicava o que ali era, que se buscava uma mudança de vida, opções de vida, trabalho. Lá a gente tomava o nome, ouvia a história da pessoa, tudo isso. Via de onde era a pessoa, o lugar. Tinha muita conversa. Fazia a acolhida, mostrava a oficina como era, dizia qual era o trabalho, qual era a finalidade deles ali, (que) é deles quererem uma transformação de vida, melhorar a situação deles. A finalidade da oficina era esta, fazer eles mudarem de vida.

Naqueles meados da década de setenta, num momento em que não existiam ONGs disseminadas pelo território da cidade e tão pouco havia ocorrido o boom do terceiro setor que posteriormente se viu na década de noventa -, a OAF era uma organização com várias atividades e que contava com um considerável quadro de funcionários e colaboradores. "Colaboradores, porque na época não se falava essa coisa de voluntariado". A organização coordenava um espaço de trabalho coletivo, a Oficina São Bento; uma residência para meninos, a Casa dos Jovens; um abrigo noturno para pessoas em situação de transitoriedade que, posteriormente e sob outra coordenação, ficou conhecido como albergue Ligia Jardim; além disso desenvolvia a já citada Ronda Noturna, quando então se saía na noite com instrumentos, alimentos e se conversava e se interagia com meninos de rua, migrantes desempregados, mulheres solteiras e outros personagens da noite; também se tinha várias 
atividades durante o dia, como o acompanhamento dos doentes nos hospitais, o apoio no processo legal de alguns prisioneiros, bem como encaminhamentos e conversas no interior das prisões.

Como as atividades desenvolvidas pela OAF eram amplas e diversificadas, seu público-alvo também era bem amplo e heterogêneo. E Fortuna chegou a participar em várias das atividades ali promovidas: vendeu coisas e jogou bola com as crianças na rua, visitou cortiços, chegou a dar apoio jurídico em presídios e, inclusive sobre isto, conta o caso de quando, numa rebelião, chegou a servir como refém. Também participou de grupos de discussão e ajuda a pessoas que tinham tentado suicídio. E foi através de histórias que ouviu sobre este grupo de discussão que Regina, outra Oblata, ficou sabendo da existência da OAF e quis conhecê-la.

E Regina conhece e chega na OAF num momento de intensas transformações. Sua inserção neste mundo se faz precisamente no momento em que a trajetória da OAF começa a passar por uma importante inflexão. Aquela heterogeneidade de focos e ações promovidas pela organização, a partir do final da década de setenta, começa a ser revista. Aos poucos, as maneiras de fazer, bem como seus alvos, vão sendo melhores delimitados. E os focos de ação gradativamente vão se direcionando mais e mais para o universo da rua. Mas a própria chegada de Regina na OAF reflete uma alteração em sua trajetória pessoal. Alteração de percurso e mudança de vida que vale a pena aqui ser relatada.

\subsubsection{Irmã Regina ${ }^{16}$}

Irmã Regina, junto com Irmã Ivete, são as duas únicas Oblatas que até hoje permanecem trabalhando na OAF, dedicando-se aos vários projetos sociais em andamento. Apesar de ter nascido em Botucatu, Regina se criou em Assis, no interior de São Paulo. Veio ao mundo em 1952 e, em contraposição a Fortuna, Regina é a Oblata mais jovem. De família católica e com oito irmãos, sua formação religiosa inicia-se em casa mesmo e fica a cargo da mãe. Apesar da forte educação que teve na infância, conta que sempre foi um pouco crítica à vida religiosa. Estuda e começa a trabalhar logo cedo. Até que conhece o Movimento dos Focolares, “isso mesmo, Foco-no-lar". Assim, com seus vinte anos, Regina entra num Movimento que, apesar de ser leigo, é diretamente ligado à igreja católica e possui em seus princípios alguns referenciais, tais como: comunhão de bens, conversão e transformação

\footnotetext{
${ }^{16}$ Regina Maria Manoel foi entrevistada em 18/07/2006
} 
pessoal. Movimento que também "é de elite", nos explica, apesar de não possuir influência política, nem mesmo dentro da Igreja Católica. De origem italiana, este Movimento possui várias ramificações, e Regina começa a participar do ramo da juventude. Assim, junto com outros jovens de Assis, passa a organizar reuniões, festas e encontros, "coisa bem de movimento de jovens mesmo". E nestas ações se entrega, "porque é uma característica minha, que quando eu acredito numa coisa, eu me dedico cem por cento”. Em Assis mesmo, começa a fazer uma faculdade de Letras, que mais tarde vai largar. Aos poucos, vai refletindo e acha que tem que seguir o caminho proposto pelos Focolares, só que para fazer esse caminho, ela tinha que se mudar para São Paulo, onde se localizava a sede do Movimento. Então em 1975 sai de Assis, deixa família, amigos e seu antigo emprego nas Casas Pernambucanas. Chegando em São Paulo tudo novo, casa, trabalho e a cidade. Uma cidade muito diferente da sua, uma vida muito diferente da antiga. Uma mudança difícil, dura, "horrível".

Apesar de ter tido uma difícil chegada na cidade, nem tudo é tão terrível assim. Vai morar no bairro de Pinheiros, dividindo o apartamento junto com um grupo de jovens garotas e logo no dia seguinte, quando já sai em busca de emprego, consegue um trabalho num escritório de advocacia: "Naquela época era mais fácil". Depois de um tempo, vai dar aulas numa escola e presta um concurso público. Passa no concurso e vai trabalhar na Secretaria da Promoção Social do Estado de São Paulo e durante este período continua assiduamente a desenvolver suas atividades com o Movimento dos Focolares. Muda-se, então, para Vargem Grande, próxima à célula mãe do Movimento, onde vai "fazer uma experiência mais intensa para depois seguir o caminho, que teria que ir para a Europa”. E nesta experiência, Regina realmente se envolve cada vez mais. Integra um conjunto musical e faz várias apresentações em outras cidades. Estas ações musicais, nos conta, eram "instrumentos de divulgação da espiritualidade". Posteriormente, todas estas competências adquiridas e desenvolvidas por Regina - tanto sua reconhecida "habilidade com assuntos práticos", adquirida na organização do Movimento e no trabalho da Secretaria, quanto seu conhecimento musical - seriam reempregadas em outras circunstâncias.

Neste período, seu regime de vida fica um pouco mais rígido, pois como morava e desenvolvia suas atividades em Vargem Grande e trabalhava na secretaria da Promoção Social em São Paulo, tinha que "viajar todo dia" num ônibus intermunicipal. Depois de um ano naquela experiência religiosa intensa e naqueles deslocamentos espaciais cotidianos, Regina passa a refletir mais criticamente sobre sua própria trajetória. E neste processo de auto-reflexão começa a se manifestar, questionar e "chamar a atenção do pessoal do movimento". Aqui a narrativa de Regina expõe um momento tenso e crítico de sua 
experiência pessoal. Episódio cheio de dúvidas, incertezas e insegurança, contudo determinante aos futuros cruzamentos de seu itinerário. Insatisfeita com os rumos que sua vida tomava, Regina abandona o caminho que havia iniciado anos antes. A decisão de ter de sair do Movimento não é ela que toma, são outros, até pela dissonância que ela começa a criar lá dentro. Entretanto, a decisão do lugar para onde ir é ela que deve tomar. Como na narrativa de Fortuna, o relato de Regina apresenta sua trajetória numa espécie de bifurcação.

Momento complicado em sua vida e dobra importante em sua trajetória, esta passagem é bastante expressiva das condições de escolhas e do horizonte de possibilidades que Regina foi construindo em seu percurso. Contudo, opta por voltar para São Paulo e vai morar com as colegas de Pinheiros: “A gente vivia ali aquela vida de pequena burguesa. Não saíamos de Pinheiros, tinha tudo lá. Só para você ter uma idéia, comprava minha roupa no shopping Iguatemi, que era o único shopping que tinha na cidade". É a partir daquela vida, entre amigas, bem vestida e num bairro nobre da cidade, que Regina começa a transformar e "aplicar uma torção" sobre sua própria maneira de ver e sentir o mundo, pois a partir dali é que vai começar a ingressar em um outro universo de relações. E aquilo que vai colocá-la em ressonância com estas novas relações são justamente as histórias que ouve sobre o trabalho desenvolvido por Fortunata.

Enquanto ainda estava lá em Vargem Grande, Regina tinha feito uma amiga que também morava no Movimento e trabalhava em São Paulo, desenvolvendo atividades com pessoas em crise e que haviam tentado suicídio. Todo dia, quando esta amiga chegava do trabalho, contava histórias para Regina. Histórias diferentes, que causavam interesse, faziam pensar e que foram ficando na sua cabeça. E esta amiga trabalhava com Fortunata:

E aí um dia ela chegou e disse que na OAF estavam precisando de uma pessoa para trabalhar. Aí eu falei: "Eu vou lá". Eu que já estava descontente com tanta coisa e de qualquer jeito queria achar alguma coisa que me respondesse mais. Tinha também essa questão social que me incomodava profundamente. Ela me convidou e aí eu vim encontrar a Ivete e a Nenuca.

É através das histórias de sua amiga que Regina se conecta a um novo jogo de relações, que vão colocando-a em proximidade com um universo até então desconhecido para ela. Não à toa, seu relato descreve este episódio como uma abertura para um novo horizonte de possibilidades e mais uma vez sua narrativa apresenta um estranhamento com este novo. Conta que aquilo tudo, aquelas novas experiências começaram a afetá-la profundamente. 
Tudo ali era muito diferente do que até então conhecera. A partir deste momento decisivo, sua vida começa a se conectar com outras linhas de vida, outras trajetórias e práticas, que com o tempo vão se transformar. Regina entra em contato com muitas pessoas novas. Conhece as irmãs Nenuca, Cristina, Fortunata, de quem sua amiga sempre falava, bem como Ivete que havia chegado a pouco do Recife. Havia também um colaborador muito ativo chamado Luiz Kohara, que freqüentava assiduamente o grupo, além de muitos outros participantes oriundos ou não da rua. Até então, Regina continuara trabalhando de manhã na Secretaria da Promoção Social, para à tarde poder se dedicar mais às atividades da OAF. Participa de reuniões, vai à Ronda e joga bola com os meninos na rua.

Na ocasião, Regina estava para assumir a chefia de um dos setores da Secretaria de Promoção Social. Só que nos conta que tudo aquilo que estava vivendo na rua a fez refletir sobre os futuros rumos de sua vida. E então decide pedir exoneração de seu cargo. Aqui vemos uma reviravolta em sua vida. A organização de seu relato atesta esta passagem como um momento importante em sua trajetória, um momento de assunção. E, mais uma vez, vemos uma reflexão sobre a possibilidade de escolha e a ambivalência do itinerário vivido. Regina não assume o cargo da Secretaria, mas assume uma posição num outro jogo de relações:

Quando eu cheguei na Secretária para dizer isso, o pessoal queria me bater: "Você está ficando maluca!”. Porque primeiro: perder um cargo efetivo, eu era efetiva. Segundo: nos próximos meses, eu ia ser indicada. Isso significaria três vezes, até quatro vezes mais o meu salário. E porque também eu podia até pedir um afastamento, podia pedir uma licença. Mas eu não quis, sabe quando você não pensa e você resolve? Porque foi muito forte. Sabe quando você encontra onde você pode realizar aquele teu ideal? E assim, quando aquele foco de luz que vem e você não tem dúvida, é aqui que você tem que colocar a sua vida?(...)

E eu era a pessoa indicada para assumir a Seção de Comunicação da Secretaria, então você imagina, eu ia para fazer carreira, digamos assim, provavelmente se eu tivesse seguido ali, hoje teria aposentado já como uma diretora. Eu poderia até ter feito as duas coisas juntas, poderia ter trabalhado na Secretaria de manhã e à tarde na OAF, mas foi tão forte para mim o impacto, que não deu.

Era o ano de 1978 quando a noviça Regina resolve morar com as Oblatas no Brás. E Regina chega neste mundo já em mudança, numa época em que começavam a discutir e a reavaliar certas práticas institucionais. Entre Oblatas, colaboradores e funcionários é feita uma profunda avaliação crítica das atividades desenvolvidas. E a partir daí uma série de mudanças 
começam a ser instituídas: os recursos públicos e privados que a organização recebia foram cortados, todo o corpo de funcionários e técnicos é demitido, fecha-se os espaços de trabalho e todos os serviços existentes são encerrados. Vemos agora uma importante inflexão na própria trajetória coletiva da OAF. Antes conectados mais aos padrões formais e institucionais de assistência, as irmãs e os colaboradores que permaneceram na organização passam então a desenvolver um trabalho mais aberto e fluido como a própria dinâmica do mundo da rua:

Com a mudança da OAF, do fechamento de todos os setores, foi um tempo de grande intensidade. Porque foi feita uma avaliação conjunta e todo mundo participava. Por exemplo, eu era do setor da ronda, mas eu fui fazer um estágio lá no setor da Oficina Abrigada, e tinha que fazer uma crítica do ensino da Oficina, dentro dessa reflexão maior. Então todos os funcionários passaram pelos outros setores, tinha um grupo de estudos que fazia um acompanhamento. Então, aí foi um tempo assim muito intenso. Já nessa perspectiva de mudança, nesse tempo depois que elas estrategicamente cortaram os benefícios, todas ficaram morando aqui no Brás. Aí fizeram um protesto de que iam começar uma dentro desse universo mais próximo da rua, uma experiência nova, foi quando a Ivete fez uma proposta de sair e vir morar aqui no Glicério (...).

Fechando todos os setores, a gente priorizou a rua, aí fizemos um movimento intenso para rua, fomos dormir na rua, a gente também foi dormir nos albergues, eu fui catar papel na rua. E aí a gente foi fazendo todas essas experiências e começamos todo trabalho direto na rua, aí foi nesse tempo que fechou a OAF, nós fechamos inclusive as rondas noturnas, ficamos só com o trabalho durante o dia, fechou tudo, então aí nós ficamos com a Casa de Oração e com o trabalho diurno, nesse tempo a Cristina saía de um trabalho mais com adolescentes e com jovens, e essa coisa foi passada para a o grupo da Pastoral do Menor que começava a ter nessa época. E a (nossa) prioridade passou a ser o adulto. A gente morava aqui no Glicério, vivia muito pertinho da rua, era um tempo também que dentro da decisão do trabalho se priorizou essa área central da cidade. (...)

Então um dos critérios para trabalhar com a rua e ser dessa equipe de base que a gente chamava, era ter que vir morar no Centro. Quem quisesse fazer parte, precisava daquilo que a gente chamava de mudança de lugar social.

Mudança de lugar social, metamorfose da organização, redefinição dos objetivos e alteração das formas de intervenção. Claro que toda esta transformação coletiva produziu enormes atritos no interior de grupo. A todo instante se colocava a necessidade de se estar refletindo e justificando os novos rumos agora tomados. Desentendimentos, acusações, dúvidas, incertezas e desgastes. E as discussões e os dissensos não ocorreram só entre aqueles 
que trabalhavam na instituição, mas também entre os "assistidos" da OAF, que acreditavam ter perdido a acolhida dos serviços. Não por acaso, Nenuca afirma em seu livro que este deslocamento do trabalho para uma "linha mais comunitária", "foi das coisas mais arriscadas que fizemos" (Castelvecchi, 1985:107). Atitude arriscada, pois a proposta então seria abandonar a perspectiva individual e tratar de formar grupos, trabalhar em grupos para a “conscientização de que a situação é social e não individual". E esta passagem do indivíduo para o coletivo é vista com desconfiança por muitos, já que na época não se levava muito a sério a possibilidade da formação de grupos operativos com os então "mendigos".

E neste processo, o grupo de trabalho fica mais reduzido e novos referenciais vão começar a surgir. As transformações das relações ali colocadas vão na direção de radicalizar a convivência com os "marginais", aproximando-se dos "mais pobres entre os pobres" e distanciando-se das antigas formas institucionais de abordagem. E a crítica às formas institucionais de ação se assentavam pelo menos em dois eixos: a instituição opera mediante o trabalho individual, impossibilitando assim o trabalho coletivo e comunitário, que então passava a ser uma importante referência; e a instituição é intermediária da caridade, sendo responsável pela manutenção da distância social entre classes, pois "aquele que manda o dinheiro de cima não se compromete com aquele de baixo".

No entanto, esta inflexão que a OAF e seus participantes atravessam está em consonância direta com o tempo de uma época. Ou seja, esta inflexão na trajetória da OAF situa-se precisamente na virada dos tempos da cidade, momento em que novas formas de mobilização coletiva, ação política e organização popular pululavam aqui e ali por toda São Paulo. E neste importante momento da nossa história urbana, em que era possível ver todo "o povo em movimento" (Singer; Brant, 1983), a Igreja Católica e suas bases de articulação locais tiveram um papel fundamental. Além de todas as reflexões e discussões que já ocorriam no interior da organização, em 1979, Dom Paulo Evaristo Arns, então Cardeal Arcebispo Metropolitano, pede à OAF que "tragam, quando puderem, o programa de Puebla para o centro de São Paulo" (OAF, 5:1982). E assim as Oblatas começam a articular e trazer para o centro da cidade todo um conjunto de referências ligadas à Conferência de Puebla, momento histórico em que a Igreja Católica da América Latina reformulou suas diretrizes de ação, lançando os elementos que iriam incitar ainda mais a proliferação das Comunidades Eclesiais de Base, que então se multiplicavam pela periferia de toda São Paulo. Só que diferente das CEBs, as Oblatas vão então fundar uma comunidade de base em outra periferia urbana: na periferia do centro. 
No começo de 1979, um grupo de religiosos começa a morar na Baixada do Glicério, numa pequena casa localizada na Rua dos Estudantes. Este grupo começa também a se envolver diretamente com as relações ali existentes e com o universo da rua. Vão dormir nas ruas e em albergues, alguns catam papelão, vendem cafezinho nas ruas e passam a visitar com mais freqüência "mocós", "malocas" e outras ocupações do Centro. E sintonizados com os rumores deste tempo e trocando experiências com outras CEBs da periferia paulistana, começa-se a querer transformar os "pobres e marginalizados do centro" em "povo", considerar a "classe sofredora" em seu conjunto, estabelecer corpo e unidade à heterogeneidade de experiências individuais na rua e encontrar, neste Povo da Rua, o Povo de Deus (OAF, 1982).

Assim, são criados espaços para se trocar histórias individuais e as pessoas falarem de seus problemas, e a partir desta convivência entre diferentes experiências comuns ajudá-los a ver-se como grupo social. E é aí que surge a Comunidade dos Sofredores da Rua. Comunidade, pois a experiência deveria ser coletiva; sofredores, pois se queria mudar a visão que eles tinham sobre si de "maloqueiros", suscitando uma dimensão mais reivindicativa nas formas de identificação coletiva; e da rua, pois é neste universo que habitavam e circulavam estes personagens:

Quando a gente se mudou para o Glicério, já tinham os encontros aos domingos na Casa de Oração. Tudo muito no começo, onde foi a primeira assembléia com o Povo da Rua. No primeiro momento a nossa casa que era referência, a Ivete fazia reunião com o pessoal. E depois aqui no Glicério houve um desenvolvimento maior, pela sopa que a gente começou a fazer lá no viaduto, pelo trabalho dos Catadores. E aqui essa expressão de comunidade era muito forte. E aí nós fizemos um teatro uma vez. Neste teatro, as pessoas que não eram da rua chamavam o Povo da Rua de maloqueiro, e aí eles respondiam que eles não eram maloqueiros, eles eram sofredores. E isso ficou muito forte para gente, e essa denominação veio deles. A gente ia ter um aprofundamento, não chegamos a tanto, mas era muito mais a visão do Servo Sofredor, aquele que resiste, é uma passagem da bíblia. O Servo Sofredor, que é a figura daquele que resiste apesar de todo o sofrimento, apesar de todo o escárnio que sofre, quando chutam e cospem no corpo dele. E toda a resistência de não perder a vontade, essa altivez. E aí então ficou a Comunidade dos Sofredores da Rua. E na época havia muitas formas de expressão, havia teatro, havia música e isso foi se divulgando. Então a Missão que fizemos ficou como Missão da Comunidade, Missão dos Sofredores. E fizemos a primeira Missão na Casa de Oração lá na Florêncio de Abreu, quando ficávamos dois, três dias 
fazendo convivência. Nesse tempo também havia contato com o pessoal das favelas, das ocupações, dos cortiços, havia um intercâmbio (...).

Em 79 nós fizemos essa primeira Missão, para discutir a realidade. Então foi nessa primeira Missão que apareceram reivindicações. Tinha uma mulher chamava Natália, uma das reivindicações dela era ter privada e banheiro na rua, então já começava uma consciência. Isso numa assembléia.

Perg.: E como que era a assembléia?

Era esse grupo que vinha e nós fazíamos um grande encontro e começávamos a discutir, fazíamos grupos para discutir temas e aí trazíamos os resultados, fazíamos uma placa e trazíamos a placa. E aí em 80 a gente fez a Missão novamente em setembro e decidimos fazer a primeira caminhada. Foi aí que decidimos sair para rua. Até então a gente nunca ia para rua, até então era mais um trabalho ainda mais local. Aí depois nós fomos para rua, tinha a sopa aqui na rua. No viaduto, porque um dos objetivos era esse de dar visibilidade.

Aqui a narrativa de Regina estabelece importantes elos com outros elementos que vivenciou, elementos que se misturam e articulam sua própria trajetória pessoal com outras trajetórias pessoais e coletivas. A experiência da sopa debaixo do viaduto do Glicério, o trabalho com os catadores de papelão, os teatros e as discussões, a troca da nomeação de "maloqueiros" pela de "sofredores", a Casa de Oração, a assembléia do Povo da Rua, a Missão, os intercâmbios com outras bases populares locais, o processo de politização e a intenção de dar mais visibilidade à questão. Cada uma destas experiências foi se constituindo em tempos e espaços específicos, e esta enorme multiplicidade de componentes heterogêneos são aqui articulados, simultaneamente, num só trecho do relato. O fluxo narrativo de Regina é capaz de elaborar e coligar uma pluralidade de diferentes materiais mnemônicos num só golpe. Contudo, vale a pena detalhar um pouco mais algumas destas memórias e experiências. E neste processo, talvez a apresentação de um outro personagem atuante neste cenário possa nos auxiliar bastante.

\subsubsection{Luiz Kohara ${ }^{17}$}

Luiz Kohara é hoje, dentre outras coisas, um dos principais participantes e fundadores do Centro Gaspar Garcia de Direitos Humanos, uma ONG que atua no centro de São Paulo e

\footnotetext{
${ }^{17}$ Luiz Kohara foi entrevistado em 20/03/2007
} 
possui um importante papel na articulação política dos movimentos de moradia da região, bem como de outras categorias de atores provindos das classes populares, tais como os catadores de materiais recicláveis e moradores de rua. Contudo, o valor de sua singular trajetória não reside somente nisso. Luiz, além de ter desenvolvido um importante percurso de vida marcado pela luta social em prol da "moradia digna no centro da cidade", também acompanhou todo o processo de transformação coletiva pelo qual a OAF e seus colaboradores passaram. Conto, então, parte de sua trajetória que gentilmente me foi narrada, durante uma entrevista, na sede do Centro Gaspar Garcia de Direitos Humanos, localizado próximo à estação de metrô Armênia.

Procedente de Adamantina, uma pequena cidade do interior paulista, Luiz, quando criança, ajudava seus familiares,que tinham um bar na rodoviária da cidade. Ali, naquele importante estabelecimento público e de passagem da cidade, tinha contato direto e observava diariamente um enorme trânsito de pessoas e famílias, vindas em geral do Nordeste ou Minas Gerais, que ficavam com sacos de pertencente dormindo na rodoviária a espera de colocações nos sítios da região: "Cresci vendo muita migração". Luiz conta que foi deste relacionamento com as pessoas da rodoviária, deste intenso fluxo, trânsito e mistura de pessoas, que aos poucos foi estabelecendo certas referências sobre a experiência da pobreza e da migração. Inclusive, quando criança, fez amizade com uma dessas peculiares alteridades que rondam estes espaços de passagem e das quais normalmente "a molecada tem medo": a relação com este "mendigo", que freqüentava e bebia ali no bar de sua família, também é narrada como um elemento importante na construção de uma experiência com a pobreza de rua.

Após terminar o colegial, em meados da década de setenta vem para São Paulo fazer faculdade de engenharia e trabalhar. Passa num concurso e consegue um emprego no Banco do Brasil, onde trabalha até os dias de hoje. Entretanto, mesmo conseguindo este emprego, afirma que "queria fazer alguma coisa. Ainda não estava muito claro, mas queria colaborar com alguma coisa". Assim, envolve-se em encontros de jovens ligados à igreja católica. E destes encontros que participa, tem contato com a teologia de libertação e metodologias de educação popular. É a partir deste envolvimento, entre estudantes, seminaristas e militantes, que Luiz fica sabendo da existência de um grupo de pessoas que trabalha com "gente da rua". Deste modo, em 1975, Luiz e um grupo de jovens vai conhecer a OAF:

Aí tinha uma reunião para os colaboradores e tenho quase certeza que foi a Nenuca que estava lá. Éramos uns 15 jovens moleques, acho que o mais velho só tinha uns 21 anos. Lá eles explicaram todo o trabalho que se tinha na OAF. E tinha trabalhos com meninos, outros 
trabalhos com egressos, tinha trabalho de refeição, tinha trabalho de albergue e outras coisas. E tinha trabalho também com a ronda noturna, que era visitar o pessoal durante a noite, levar lanche, chá e no inverno levar cobertas. Como era um trabalho mais político, para se fazer de noite na sexta-feira e no sábado, eu topei. Até porque achei mais interessante trabalhar diretamente com a rua e isso foi o que me chamou mais a atenção (...).

Fortunata era muito conhecida na rua, então quando a gente saía na ronda sem ela, a gente falava que era amigo da Fortunata. E ela era o primeiro cartão de entrada para se aproximar e poder conversar com as pessoas. Às vezes a Fortunata levava violão, a gente parava, cantava, às vezes até as $4 h$ da manhã. Era um aspecto assim, de você ver uma realidade de pobreza de quem estava na rua, às vezes a gente encontrava uma situação bem grave ali. Mas também era uma forma muito gostosa de se relacionar, para mim isso nunca foi uma coisa pesada.

A partir desta experiência da ronda com irmã Fortuna e outros participantes, Luiz vai aprofundando-se mais e tendo um maior contato com o universo da rua, seus habitantes e suas particularidades. Após um ano de participação naquelas atividades, envolve-se mais ainda com a organização. Passa a trabalhar à noite no Banco do Brasil e de dia fica desenvolvendo atividades variadas junto ao universo da rua. Apesar de continuar estudando de dia, Luiz conta que achava "o trabalho com a OAF muito mais importante que a faculdade". Neste período, já se fazia um intenso questionamento que o trabalho deveria ser "muito mais que ir dar lanche e socorrer a pessoa na rua de imediato". O intenso momento político da época fazia as práticas ali desenvolvidas serem constantemente interrogadas sobre sua real finalidade. Estas posturas e metodologias de trabalho vinham sendo elaboradas a partir da troca de conhecimentos com outras experiências que então se desenrolavam na cidade de São Paulo:

Tanto que naquela época fomos visitar várias comunidades de base de alguns lugares para ver como se organizavam, ver se era possível trazer um pouco destas experiências vividas. Queríamos trazer um pouco da riqueza das CEBs para trabalhar com a rua. Então eu acho que tudo isso, num processo, em 78, isso daí começou a questionar a estrutura da OAF, que era uma instituição grande, com mais de 50 funcionários, albergues, casas com adolescentes e outras casas (...) Até porque uma preocupação era a de colocar esta realidade da rua dentro do contexto mais amplo, e não um contexto apenas do pobre que está na rua e que precisa de alguém, precisa ser ajudado. Então acho que, assim, a riqueza de reflexão deste momento veio também desta agitação política (...)

Partindo das experiências das comunidades de base, a partir do que colocava a Teologia da Libertação, a libertação vindo dos pobres, onde você via a pedagogia de Paulo Freire, onde 
reconhecia o saber de cada um, um saber que tem que ser desenvolvido, que tem valor, que tem competência. Competência também já era uma palavra nova na época. O processo era o de reconhecer naquela pessoa da rua uma capacidade e também reconhecê-la dentro de uma estrutura social.

A partir de então se inicia, gradativamente, a reformulação já comentada da OAF. Contudo, ao mesmo tempo em que se tornava cada vez mais claro que a experiência de pobreza nas ruas da cidade estava conectada à desigualdade social, o próprio Luiz reconhece que "estar na rua é uma questão toda econômica, mas também possui um aspecto mais profundo". Esta maior "profundidade" do tema expõe uma dimensão que não se reduz unicamente às explicações macroestruturais, apesar de vincular-se a estas. Por enquanto, vale a pena apontar que esta irredutibilidade ao econômico é um dos elementos que também vai permitir estabelecer discursivamente a singularidade desta configuração de pobreza urbana em relação a outras. No entanto é justamente a partir do reconhecimento de que a experiência de rua atrelava-se, ainda que de maneira muito específica e particular, com outras formas de pobreza e privação material, que o trabalho desenvolvido pela OAF e seus participantes começa a voltar-se para uma prática de caráter mais comunitário, assim como aquelas que se desenrolavam na crescente periferia da metrópole.

Em 1978, a OAF e seus colaboradores conseguem um espaço para convivência e celebração, "onde as pessoas pudessem estar manifestando sua fé da forma que quisessem". Em verdade o espaço era "um casarão abandonado", como nos diz Luiz. É este casarão, localizado ao lado do Mosteiro de São Bento e cedido temporariamente pelos Beneditinos, que vai ser a primeira Casa de Oração, onde se organizará a primeira Missão do Povo da Rua e se discutirá coletivamente sobre quem é esse povo. Luiz explica que, assim como as CEBs, que estavam preocupadas em construir uma identidade positiva aos pobres da periferia, esta questão também era colocada para a Comunidade dos Sofredores de Rua do centro da cidade:

A gente trabalhava muito essa questão da idéia de povo, contrapondo às palavras mendigos, maloqueiros. Então valeu bastante a questão do Povo da Rua. Eu acho que não é uma questão à toa. A comunidade começou a chamar sofredores da rua e tinha um caráter de reconhecer o sofrimento, mas a gente questionava muito, porque tem um aspecto de resignação quando se fala sofredor. Não é tão legal esta questão de sofredor, mas ficou porque a população logo pegou. Mas serviu também para reconhecer que ele não era maloqueiro, ele era sofredor, que ele não era sozinho, era parte de um povo e de uma reflexão de fundo e que dava bastante sustentação a esta questão (...) Três anos depois, se discute que precisava ter uma identidade 
a partir do positivo, eu lembro da reunião que a gente criou a frase, "Somos um povo que quer viver" e depois isso virou o livro, quando a gente começou a sair na rua (...) Esta frase era pra reforçar o aspecto positivo. Quem é esta população? É a população que quer viver e que está sendo impedida de viver.

Nas reflexões conjuntas, também se colocava constantemente a necessidade de se aproximar mais diretamente deste universo. No seio destas relações, entre oblatas, reuniões, colaboradores, sopas e diferentes pessoas, elementos e demandas oriundas do mundo da rua, foi se testando e experimentando toda uma ordem de expectativas e tentativas de ação conjunta. E neste processo foram se criando saberes singulares, com modalidades próprias de "fazer junto". A questão de como lidar com estas pessoas marcadas pela rua, sem reproduzir as abordagens institucionais de outrora, foi um dos principais motores na manipulação de novos materiais, para uso conjunto e na utilização de novas metodologias de trabalho coletivo.

Muitas experiências são efetuadas neste período, tal como a já citada sopa comunitária organizada por irmã Ivete e que, segundo Luiz Kohara, "tinha uma intenção pedagógica muito grande, que era poder fazer o que o povo já faz". Contudo, uma questão que se colocava naquele momento era "se nós vamos visitar a pessoa da rua na hora que a gente quer, ela deveria ter liberdade de nos visitar a hora que quiser". É na tentativa de estabelecer um contato mais direto com este universo que é criada a Comunidade dos Sofredores de Rua, formada por três bases de trabalho na região central da cidade: Luz, Glicério e Parque Dom Pedro. Nesta nova territorialização dos atores e suas práticas, pretendia-se estabelecer locais de referência no centro de São Paulo, três casas abertas e estáveis que funcionariam como baliza na tarefa de vencer a dispersão que era vista na rua para, assim, facilitar o conhecimento entre as pessoas. O programa era simples: "colocar as bases e abrir os caminhos para reunir o povo que está disperso" (OAF, 1982:69).

Nesta época, Luiz, que até então morava com seus irmãos na Bela Vista, muda-se para a área central da cidade, no bairro da Luz. Apesar de atuar no grupo do Parque Dom Pedro, Luiz morava próximo à casa da Nenuca, onde também se configurava outra das bases de referência da Comunidade. Mesmo afirmando nunca ter desejado entrar num seminário tampouco ter sido religioso, Luiz diz que neste período de sua trajetória viveu como um. Isto devido à imensa dedicação junto a este universo, não só trabalhando, mas também convivendo e dormindo algumas vezes nas ruas. Reconhece também nessa experiência toda, "um aspecto meio de aventura". 
No decorrer da década de oitenta permanece freqüentando ativamente a Comunidade dos Sofredores de Rua. Até que, num momento “de muitas dúvidas”, resolve sair, já em 1987. Esta saída é narrada como uma difícil passagem em sua trajetória, episódio cheio de incertezas e dificuldades. Isto não por acaso, já que Luiz chegou na OAF com 21 anos e quando saiu, tinha 33 anos. Sua narrativa apresenta este momento de sua vida, junto à Comunidade dos Sofredores de Rua, como um importante episódio de aprendizado em seu percurso de vida. Lá teve conhecimento com maneiras de fazer e formas de trabalho que puderam ser reempregadas em outras situações e contextos pelos quais sua trajetória posteriormente se enredou.

A saída de Luiz não representa uma ruptura com as relações então estabelecidas, mas reflete em verdade um importante processo de transformação de sua vida que acompanha e se articula com outros deslocamentos contemporâneos, e que por fim deságua em novas conexões com outras trajetórias e práticas, bem como num novo jogo de relações, que passa então a ser forjado no bojo da experiência social destes atores. Junto com outras pessoas, algumas ligadas à Pastoral da Moradia, outras que trabalhavam com a questão dos cortiços e dos direitos humanos na região central, Luiz Kohara passa a formar a entidade Centro Gaspar Garcia de Direitos Humanos. A construção desta organização é narrada por ele como um processo coletivo, do qual vários atores participaram e em que foram discutindo sobre "a dimensão da pobreza que estava também no centro e não só na periferia da cidade”. Apesar de se preocuparem e se envolverem com as diversas formas de pobreza da região central, 0 principal foco de atenção desta organização é a "questão da moradia digna no Centro":

Foi tudo um processo. Na verdade, assim, não é continuação da OAF, mas tem muito daquilo que a gente viveu, deu, aprendeu, ensinou. Acho que a troca com a OAF foi criando, deu um toque para o pessoal da moradia, a organização da população da moradia. Acho que a gente teve um papel importante nisso.

O conhecimento e habilidade aprendidos na Comunidade dos Sofredores de Rua, Luiz Kohara reemprega no Centro Gaspar Garcia. Assim, esta organização também começa a trabalhar com um público vinculado ao universo da rua. Na gestão municipal de Luiza Erundina (1989-1992), esta entidade consegue um convênio com a prefeitura, para coordenar uma casa de convivência localizada na Rua Nioac, próxima à Praça da Sé ${ }^{18}$. Posteriormente,

\footnotetext{
${ }^{18}$ As casas de convivência e a construção de convênios com a prefeitura serão melhor debatidas no desenrolar das próximas trajetórias. Vale apontar, entretanto, que a trajetória de Luiz Kohara e do Centro Gaspar Garcia de
} 
com a mudança de gestão do poder municipal, o convênio não continua, mas a casa é mantida com parcos recursos. Desta experiência junto às pessoas que viviam e trabalhavam na rua é que se começa a organizar coletivamente o trabalho dos catadores, que freqüentavam este espaço. Deste trabalho surgiu a Coorpel (Cooperativa de Reciclagem de Papel, Papelão e Materiais Recicláveis). A cooperativa começou a partir de um pequeno grupo de catadores que, em 1990, formaram a Associação Nioac, como forma de aumentar seus ganhos. Em 1998 a Coorpel é fundada, passando a trabalhar nos moldes de uma cooperativa.

Atualmente esta cooperativa continua recebendo apoio do Centro Gaspar Garcia de Direitos Humanos, contudo sua formação teve como importante referência outra cooperativa de catadores, a Coopamare (Cooperativa de Catadores Autônomos de Papel, Aparas e Materiais Reaproveitáveis), esta última constituída a partir das atividades da Comunidade dos Sofredores de Rua, da qual Luiz Kohara também fazia parte. E com o intuito de detalhar um pouco melhor esta experiência é que reporto à singularidade da trajetória de um outro personagem, este agora diretamente conectado aos percursos temporais que permitiram a metamorfose de sofredores de rua em catadores organizados na cidade de São Paulo ${ }^{19}$.

\subsubsection{Carlinhos $^{20}$}

Hoje Carlinhos trabalha na marcenaria da OAF, localizada na Baixada do Glicério, mas diz que este serviço é temporário e que, "rapidinho, rapidinho", pretende arrumar coisa melhor. Logo no começo da entrevista, que se deu ao lado de seu espaço de trabalho, Carlinhos explicou ter recentemente passado por uma "barra pesada". Tinha voltado a beber, o que provocou uma "recaída" e uma "bagunça" em sua vida. No momento de nossa conversa, fazia vários meses que Carlinhos não bebia, no entanto a "recaída" fora tão forte, que até então não tinha conseguido se estruturar e voltar a trabalhar na catação ou na cooperativa, da qual fora um dos fundadores.

\footnotetext{
Direitos Humanos acompanha os processos políticos posteriores, bem como se articula temporalmente com as alterações dos poderes públicos municipais e outras trajetórias que aqui serão expostas.

${ }^{19}$ Parte deste percurso histórico, no qual os catadores aos poucos vão se colocando como sujeitos políticos na cidade, já foi parcialmente apresentado em outra obra (Domingues Jr., 2003). Contudo, as colocações aqui presentes apenas visam pontuar certos elementos deste processo através da trajetória de Carlinhos, com a intenção de permitir uma maior articulação com o conjunto das discussões levantadas no corpo do trabalho. Apesar do tema deste capítulo ser propriamente as mediações envolvidas com o nascimento da questão população de rua, deve-se ter em conta que é inviável omitir o importante papel que a figura dos catadores tiveram neste processo, bem como os posteriores remanejamentos no qual se envolveram, participando e redefinindo a questão. Assim, o tema catadores estará presente, mas apenas tocará tangencialmente algumas das discussões nos três capítulos da dissertação.

${ }^{20}$ Carlos Fabrízio foi entrevistado em 27/01/2007
} 
De família pobre do interior de estado de São Paulo, Carlinhos, como é conhecido, chega na capital paulistana em 1975, à busca de trabalho. Habilidoso com as mãos, faz de tudo: é soldador, pedreiro, carpinteiro, pintor e "mais o que precisar fazer". Trabalha em vários lugares, empresas, indústrias e construções. E é justamente esta sua trajetória profissional segmentada que permite que aprenda as "novas manhas" dos serviços, até então desconhecidos. Só que na passagem para a década de oitenta, fica cada vez mais difícil de conseguir um emprego. Então arruma um serviço como soldador em Cubatão e este é o último trabalho registrado de que possui lembrança. Depois disso, não consegue mais nenhum serviço e a explicação ele mesmo tem: "É, Daniel, você deve saber melhor que eu que foi no começo dos oitenta que o desemprego apertou". E em seguida é só "tropeço", como ele mesmo fala. Faz um bico aqui, outro ali, mas "um serviço decente mesmo" não arranja. Com trinta anos de idade, no auge de sua força produtiva, Carlinhos vira um morador de rua: "Fui parar no meio da rua". Arranja um "mocózinho" debaixo do viaduto, faz uns conhecidos por ali e continua fazendo uns bicos, "tentando, não é?".

Trabalhador que "não deu certo", Carlinhos integra aquela enormidade de "casos sociais" que vão encontrar nas ruas da cidade uma forma de vida nada usual, apesar de crescente. A rua transforma-se, então, num espaço de "viração", espaço social onde se é possível praticar a sobrevivência. A trajetória de Carlinhos segue, até então, todas as características básicas apontadas pelos estudos sobre moradores de rua: um itinerário de perdas sucessivas que o leva à rua, o coloca distante da família, próximo da bebida e longe do mundo do trabalho. Nos dizeres de Robert Castel (1998), ele seria o desfiliado em pessoa. Seria, se nós parássemos por aí a história, ou melhor, se Carlinhos parasse aí sua história. Só que ali no meio em que vive, "no meio da rua", Carlinhos envolve-se em muitas relações, com pessoas e coisas, e descobre novas formas de trabalho, ainda que não muito reconhecidas. É ali, junto à proliferação do lixo, rejeitos materiais lançados ao espaço público pelos citadinos, que descobre uma fonte de renda. Carlinhos descobre a catação e junto com ela descobre também toda uma complexa teia de ligações articulando materiais recicláveis, lugares de coleta, depósitos clandestinos, carroças e catadores. E no bojo dessas ligações, circulando entre depósitos e até mesmo dormindo em alguns, é que aprende a fazer carroças com alguns dos materiais recolhidos. Reempregando as competências de suas "habilidosas mãos", Carlinhos, além de catar material reciclável, também começa a vender carroças por encomenda. "Fiz tanta carroça que eu nem me lembro quantas". Inclusive faz uma carroça para si e começa a dormir debaixo dela. 
Na década de oitenta, com o aumento do desemprego, aumenta também a presença destes personagens que habitam o mundo da rua, tanto na paisagem urbana quanto na própria mídia impressa. Um levantamento de periódicos, efetuado por Cleisa Moreno Maffei Rosa (1999), aponta o crescimento das reportagens de jornal sobre o aumento de pessoas e famílias que moram sob viadutos e marquises, em casas abandonadas, calçadas e jardins. Junto com as notícias, avança também a multiplicidade de nomeações efetuadas sobre esta experiência. E os nomes são vários: desabrigados, homeless, pobres de rua, gente morando na rua, mendigos, indigentes, exército de rejeitados, deserdados, cidadãos da rua, mas também sofredores de rua, Povo da Rua e catadores. À medida que aumenta o desemprego, o material reciclável também começa a ser visto como uma fonte possível de recursos. Em verdade, o lixo sempre fôra visto como matéria-prima para aqueles que se utilizavam das ruas como forma de vida, contudo era uma fonte mais ocasional de recursos. É na década de oitenta que isso muda, quando estes artefatos rejeitados, além de crescerem em quantidade, passam a ser seriamente vistos como possibilidade de trabalho e vida para um grande contingente populacional urbano. Seja como for, a entrada de Carlinhos neste ramo informal de trabalho se faz justamente pelo espaço de relações em que sua vida passa a se circunscrever. É que o viaduto que ele escolheu para dormir era um lugar de "movimento":

Na verdade, quando eu vim para rua eu vim para o viaduto do Glicério e aqui comecei a catar papel e papelão para vender. Porque na época, em 80, 82, tinha a rodoviária do Glicério aqui. Tinha o maior movimento de gente aqui na época. Então era melhor ficar por aqui, porque tinha a catação e a rodoviária. E assim foi indo. Eu dormia debaixo do viaduto aí na rua, onde hoje é a Associação (Minha Rua Minha Casa). Então eu dormia lá. E depois eu passei a dormir nuns caminhões velhos numa rua que tem aqui perto. E para comer, eu ia numas "bocas de rango" que tinham.

Perg.: Mas tinha serviços da prefeitura onde comer?

Não, naquela época não tinha nada. A gente ia no corpo de bombeiros. Lá eles davam uns pratos de comida. Às vezes íamos nos restaurantes e tinham também outros lugares para ir. Nada de prefeitura. E assim foi, até que em 83 para 84 eu conheci a Comunidade dos Sofredores de Rua e aí foi melhorando.

Carlinhos considera que o contato com a Comunidade dos Sofredores de Rua foi aquilo que permitiu que mudasse sua visão de mundo. Em verdade, desde seu encontro com 
as Oblatas no começo da década de oitenta, mantém relações com a OAF. Relações que no decorrer deste período variam de qualidade, intensidade e freqüência, mas que se mantêm. $\mathrm{E}$ este vínculo estabelecido, que com o tempo foi se transformando, reflete-se em sua narrativa através do modo como se refere a elas.

Como até então não havia se construído um saber institucionalizado e específico sobre a população que vivia nas ruas da cidade, também não existiam instituições públicas que trabalhassem especificamente com este tema. O que havia eram equipamentos que, diga-se de passagem, atendiam a uma enorme pluralidade de demandas, inclusive das pessoas que viviam nas ruas da cidade e buscavam pernoite ou alguma forma de apoio. O CETREN (Centro de Triagem e Encaminhamento), que ficava próximo à antiga rodoviária do Glicério, era gerido pelo governo do estado e sua finalidade específica era alocar temporariamente e, como o nome já diz, fazer a triagem e o encaminhamento da mão de obra migrante que incessantemente chegava a São Paulo, nos idos dos anos setenta e oitenta, e que já começava a não ter mais para onde ir. Outro equipamento de referência na época era o albergue Ligia Jardim, localizado na Avenida Vinte e Três de Maio. Quando fundado pela OAF, em 1978, este espaço dedicava-se ao acolhimento dos migrantes recém-chegados à cidade de São Paulo. Após a remodelação institucional da OAF, o espaço é abandonado e em 1981 passa a ser coordenado por um outro grupo religioso, a Aliança Espírita Evangélica, que se volta então para o trabalho com "homens em situação de transitoriedade e tratamento ambulatorial" (Nasser, 2001:61). O Ligia Jardim era o único equipamento que neste período se aproximava mais daquilo que atualmente chamamos de albergue. E no seio destes espaços institucionais, entre uma população heterogênea e marcada pela transitoriedade e pela enfermidade, misturavam-se também os então chamados mendigos e sofredores de rua.

Então, numa época em que os únicos espaços institucionais que atendiam "pessoas desabrigadas" eram o CETREN e o Ligia Jardim, é que Carlinhos começa a participar das "sopas comunitárias" debaixo do viaduto, quando coletivamente se ia à feira pegar os restos de alimentos, cozinhava-se e comia-se, tudo junto, "comunitariamente". Começou a freqüentar também as reuniões e as dinâmicas do Centro Comunitário. E nesta trilha, Carlinhos vai descobrindo novas possibilidades e pessoas que se encontravam em situações próximas às suas:

Porque depois, eu consegui uma moradia. Na época, a Comunidade já dava uma alternativa para gente, porque lá a gente ficava sabendo das coisas. Primeiro fui para uma ocupação lá na Rua Tamandaré, num casarão abandonado. Fui morar junto com minha companheira na 
época. E aí depois, em 1985, passei a morar aqui no Glicério, numa casinha que a Comunidade tinha. Depois eu até cheguei a comprar uma casa para mim aqui no Glicério. E foi aí que a gente formou a Associação dos Catadores de Papel em 85. Em 83 a gente começou a conversar sobre isso, mas só foi em 1985 é que a gente fez a Associação.

Num só golpe, a narrativa de Carlinhos expõe a virada de morador de rua para catador associado. Convém, portanto, detalhar alguns elementos desta passagem. As reuniões efetuadas no Centro Comunitário, além de desenvolverem atividades culturais, também promoviam discussões coletivas sobre alguns temas que apareciam. E obviamente um tema constante era o do desemprego e do trabalho. Alguns participantes trouxeram sua experiência com a prática da catação e aquilo foi ficando no grupo. Até que se colocou a questão: "se a gente tivesse um carrinho, a coisa poderia ser diferente, nós poderíamos ganhar mais". E "como primeiro passo, a própria comunidade comprou duas rodas e o grupo fez a sua carroça". A partir daí o processo foi longo, com muito trabalho e debate. Mas só foi numa Missão, momento de mobilização, organização e reflexão conjunta, que veio a idéia de se fundar uma Associação de Catadores:

Antes a gente conversava sobre isso e até a Nenuca falava que queria ver os catadores de papel unidos. Coisa que ela não conseguiu ver, porque morreu antes disso. Mas a gente continuou com a idéia. Aí pediram para eu fazer uma carroça e a primeira carroça da comunidade eu é que fiz, e se chamava gasparzinho. Depois ela foi reformada e chamaram de gasparzão. É, eu boto nome em todas as carroças que faço. Depois a Comunidade ficou com três carroças. Além disso, eu tinha a minha, alguns catadores tinham as suas e tinha gente que não tinha carroça e pedia. Aí, quem não tinha carroça, fazia um revezamento das carroças (...)

A idéia da Associação apareceu foi numa Missão, quando a gente fazia uma vaquinha e cada um dava um pouco. O dinheiro era nosso mesmo, do Povo de Rua, tudo para conseguir fazer a Missão. Então a gente se juntava para fazer vários trabalhos. Cada um trabalhava do jeito que dava. Tinha o grupo do café, da marretagem na rua, os flanelinhas e também outras contribuições individuais. E dentro disso já tinha um grupinho de catadores de papel organizado. Eram uns 10 catadores que a gente fazia este trabalho conversando junto, mas não comercializava junto, entende? E para Missão, isso exigia que a gente comercializasse junto, fizesse tudo junto, entendeu? Aí pedimos emprestado um espaço numa casa aqui velha, abandonada. A gente pediu para o senhor que tomava conta da casa, para usar o espaço e ele deixou usar a casa. E a gente armazenou papel, os materiais lá dentro, porque a gente na época já pegava de tudo, não era só papel e papelão não. E todo dia dedicávamos pelo menos 
uma viagem (de coleta) para a Missão, e a gente brincava: "se achar ouro, coisa valiosa, tem que dar para Comunidade, não pode esconder". Aí juntamos todo aquele material e no dia da venda para a Missão, recebemos o dinheiro. Aí depois a gente se encontrou, para fazer a avaliação da Missão. Que todo ano também era sempre feita e se falava o que deu certo, o que não deu, o que falhou. Só para você ter uma idéia, nosso carro de som da Missão era uma carroça e antes disso ela era na perna mesmo. Aí quando terminou a Missão, na reunião, vimos que dos trabalhos o nosso grupo dos catadores foi o que deu mais dinheiro.

Perg.: Por que deu mais dinheiro?

Deu mais dinheiro porque a gente juntou tudo, a gente não vendeu cada um separado. Aí no final da avaliação, pensamos "por que não continuamos nós? Juntos assim dá mais dinheiro”. Aí continuamos juntos, tudo na mesma casa, arrumamos uma balança, para dividir o material de cada um, dividir o dinheiro. Mas deu trabalho para caramba! Antes de arrumar a balança a gente fazia um monte individual e repartia por partes iguais, mas tinha gente que não trazia material. Aí num dava. Era briga, discussão, porque estes caras não trabalhavam e não estava certo, né? Depois se falou: "tem que pesar e descobrir o quanto pegou de material cada um, é o mais certo para fazer a discriminação do valor”. E foi melhorando, até mesmo para pagar no dia que vendia o material era mais fácil, porque se sabia quanto era a parte de cada um. E a gente foi assim trabalhando. Surgiu esta casa aí, que tava abandonada na época (atual marcenaria e sede da OAF). Entramos na casa e depois começamos a juntar o material lá, começamos a arrumar tudo. Quando tava tudo legal apareceu o dono rapidamente para reclamar. Depois em 85 viramos associação. Aí a Luiza Erundina já era vereadora e ajudava a gente. Então ela veio aqui no Glicério na fundação da Associação.

Aqui começa a se fazer presente, ainda que sob formas marginais e tênues, a figura do Estado. É neste cenário que certas ligações capilares e circunscritas começam a ser articuladas, estabelecendo pela primeira vez mediações mais específicas e especializadas entre poderes públicos e universo da rua. E estas relações obviamente não eram só de apoio, como no caso da então vereadora Erundina, que auxiliava a organização dos catadores, mas também relações que se faziam mediante o uso da força, pressão e coação política, como no caso dos embates com Jânio Quadros, prefeito da cidade entre 1985 e 1988. No começo desta gestão municipal, inicia-se uma intensa e sistemática perseguição aos catadores. Tendo a vassourinha como principal emblema de campanha, a intenção política era varrer a cidade através de uma intervenção urbana fundada numa "limpeza estética das ruas". Por considerar que os catadores sujavam as ruas ao vasculhar lugares em busca de material, Jânio Quadros também deu 
continuidade ao cerco dos viadutos, prática esta que começara a ocorrer já na gestão municipal anterior de Mario Covas (1983-1985), quando então foi desativado o Terminal Rodoviário do Glicério. E é no seio deste jogo de forças que os catadores do Glicério vão chegando a um impasse, começam a sentir a necessidade de, junto com outros catadores, buscar uma mobilização, uma organização em torno do direito de trabalhar.

A presença da vereadora Luiza Erundina no momento de fundação da Associação dos Catadores de Papel na Baixada do Glicério dá visibilidade pública e reforça a importância deste acontecimento contra as ações da prefeitura. As Oblatas possuíam uma relação com a vereadora, iniciada num trabalho desenvolvido nos cortiços do Brás, e foi esta proximidade que possibilitou seu apoio. Contudo as ações da prefeitura, através da guarda, não eram unicamente contra os catadores, pois tais intervenções produziam efeitos diferenciados nas múltiplas e dispersas relações existentes no universo da rua. Deste modo, as próprias atividades do Glicério também sofrem alguns dos efeitos das intervenções da prefeitura. Regina, que em sua trajetória acompanhou e participou do processo de formação da Associação, nos conta um pouco sobre como as ações da prefeitura também chegavam às práticas cotidianas do Glicério:

Quando nós começamos a fazer as coisas mais em público é que tivemos um embate muito grande com o Jânio Quadros. Ele queria dar para gente um galpão para fazer a sopa, para não ficar aparecendo ali debaixo do viaduto do Glicério. Ele não gostava nem um pouco daquilo ali. Imagine, naquele tempo não era um grupo tão grande como depois ficou, mas já eram cinqüenta, oitenta pessoas. Então você percebe, num tempo em que você nem via muita gente na rua e depois começa a aparecer e ver oitenta pessoas debaixo do viaduto, como é que fica? Isso incomoda, não é? Foi tão grande a perseguição dele com a gente, que a guarda chegou um dia a apagar o nosso fogo (da sopa) com extintor de incêndio. Isso em plena rua. Aí infernizaram tanto a paciência da gente, que um dia nós chamamos a polícia militar para eles. Claro que não resolveu. Aí eles mandaram a gente se entender, tal era a pressão em cima da gente. Era uma loucura, porque para aquele tempo aquilo era uma coisa muito nova. Não se via muito destas coisas: gente na rua comendo e trabalhando. E foi tudo neste período, quando o Jânio Quadros começou a proibir todas as carrocinhas da rua, e aí então os catadores daqui se juntaram com os da Luz, com os catadores da região da Sé e aí eles formaram a primeira Associação. E o Carlinhos foi um grande protagonista nisso tudo.

E foi mesmo. Com o tempo, Carlinhos passa a mostrar-se como uma importante liderança entre os catadores que resolvem ali se associar. Participa ativamente das 
organizações das Missões, quando então se faziam verdadeiros "cortejos de carroças", que atravessavam o centro da cidade chamando a atenção e dando maior visibilidade para a questão. E nestas Missões, os catadores também tentavam expressar diferenças em relação aos chamados mendigos ou maloqueiros, aderindo de forma mais contundente às manifestações de protesto ao sofrimento nas ruas, estimuladas pela OAF. Além disso, Carlinhos desempenha um importante papel na complicada economia das relações internas da Associação. E no início era "muita dificuldade, muita discussão" e até mesmo "desconfiança". Não se sabia como controlar o material, como se gerir as finanças e, também, nem se tinha equipamento e nem lugar adequado para tratar, separar e acumular os materiais recolhidos. Na época, o depósito onde se guardavam os objetos coletados ficava numa sala da casa que, pós-ocupação, foi comprada pela OAF. Uma casa que servia, ao mesmo tempo, como depósito e escritório da Associação, como habitação temporária para pessoas diretamente ligadas às atividades e relações locais, e como Centro Comunitário da Comunidade dos Sofredores de Rua. E no seio destas microconflitualidades que atravessavam todo processo, Carlinhos foi adquirindo a "manha" de conversar aqui e "amenizar" ali. Circulando entre códigos diferenciados, na rua, com os catadores, os donos de depósitos, as Oblatas, políticos e outros atores, Carlinhos vai se transformando em um importante mediador neste universo mais circunscrito. E com o tempo, vai ajeitando melhor sua vida. "Trabalhava bem para caramba, tanto que do grupo eu era o que mais pegava material". Passa a morar numa outra casinha do Glicério que a Comunidade também ocupa, e mais tarde consegue comprar uma casa própria e, até mesmo, um carro com o dinheiro juntado a duras penas pela catação. Vê-se que não por acaso tornou-se "presidente fundador da Associação dos Catadores e também presidente fundador da Coopamare", como ele mesmo orgulhosamente anuncia. E neste processo de consolidação de relações e novas formas de trabalho, outras coisas também vão se alterando, ao entrar em ressonância com outros atores e novas configurações de poder.

$\mathrm{Na}$ trajetória coletiva destes catadores, da qual Carlinhos desponta como um personagem de destaque, a entrada de Luiza Erundina na prefeitura municipal promove todo um rearranjo de relações. A mudança de gestão do poder público acompanha, portanto, uma importante inflexão no percurso destes trabalhadores, antes perseguidos. Logo em 1989, a Associação transforma-se na primeira cooperativa de materiais recicláveis do Brasil, a Coopamare (Cooperativa dos Catadores Autônomos de Papel, Aparas e Materiais Reaproveitáveis), e também consegue um espaço para trabalho na região de Pinheiros. E este espaço cedido pela Prefeitura, em condições legais não muito bem definidas, torna-se motivo 
de várias pelejas futuras. Logo na gestão seguinte, terão de enfrentar a primeira tentativa de despejo, que não ocorre apenas devido à ajuda de outro importante aliado:

E aí em diante foi esta briga que a Erundina deixou. E o processo (jurídico) que está rolando, deve estar deste tamanho. Desde o primeiro ano que a gente está lá (em Pinheiros), o poder público está querendo tirar a gente. Depois que a Luiza saiu, quem entrou foi o Maluf e já no dia seguinte ele queria tirar a gente. Foi uma briga feia com ele. Ele decretou um momento, que ele ia tirar nós de lá. Tinha até um dia e uma hora marcada para sair do lugar. Aí neste momento, a gente correu e falou com Dom Paulo (Evaristo). E cain direitinho, porque o Maluf ia fazer anos. Era aniversário dele e ele pediu para o Dom Paulo celebrar a Missa de aniversário. Aí, o Dom Paulo ligou para ele (Maluf), e disse, "que coisa é essa que você vai fazer? Vai tirar a Coopamare de lá? Isso não está certo. É o Povo da Rua. Isso não se faz”. E aí Maluf disse: "eu não sabia disso”. E foi certinho, muita sorte mesmo. No mês que o Maluf falou que era para gente sair ele fez aniversário e chamou Dom Paulo. Foi um bruta apoio, a gente estava mal lá. Aí ele se arrependeu daquilo que ia fazer. Dom Paulo fez o Maluf se arrepender.

Mesmo não se sabendo precisamente como ocorreu a negociação entre cooperados, o Cardeal Arcebispo e o prefeito da cidade, esta passagem explicita a instável condição nas quais estes trabalhadores se encontram. O episódio expõe também as relações de dependência que mantêm a cooperativa funcionando e demonstra como as alterações do poder municipal podem desestabilizar este precário equilíbrio de relações. Até hoje, segue a briga judicial para se permanecer neste espaço. Além disso, muitos vizinhos se incomodam com a presença de uma cooperativa de materiais recicláveis nas redondezas de suas casas. Afirmam que os catadores sujam o bairro e que a cooperativa contribui para a permanência de pessoas dormindo nas ruas da região. Apesar da Coopamare ter nascido a partir da organização de novas formas de trabalho com pessoas que viviam nas ruas, hoje sua composição é bem mais heterogênea, possuindo trabalhadores que nunca tiveram alguma experiência de rua.

Mas a gestão Erundina não deixou unicamente um espaço contestado para estes trabalhadores. Em 1990, através de um decreto, a prefeitura reconheceu oficialmente o trabalho dos catadores de papel na cidade de São Paulo. Este decreto, elaborado por Aldaíza Sposati enquanto secretária das administrações regionais do governo de Luiza Erundina, além de torná-los uma categoria de trabalhadores não mais clandestinos na cidade, possibilitou o registro dos mesmos como autônomos na prefeitura, independente de estarem ou não vinculados a uma cooperativa de trabalho. Esta prefeitura estabeleceu também um auxílio 
financeiro muito específico para a Coopamare, verba que então era passada diretamente para a cooperativa e posteriormente se mantinha por repasse através da OAF. Obviamente todo este processo também não se fez sem a atuação de outros mediadores, que facilitaram as conexões com o Estado e suas leis. E a importância de Paulo de Tarso, advogado membro da Senacoop (Secretaria Nacional de Cooperativismo), no processo de formalização e oficialização da cooperativa, se faz presente no relato de Carlinhos. Foi ele que ajudou a "discutir tudo junto, os nomes, escrever junto as leis, regras, o estatuto da cooperativa. Todas estas coisas. Deu a maior força". Foi ele também que achou um terreno vazio debaixo do viaduto Paulo VI, na Rua João Moura, e articulou junto aos catadores do Glicério um pedido de uso para a prefeitura. Entretanto, o que é importante reter aqui é que nesta passagem de associação para cooperativa, no deslocamento do Glicério para Pinheiros, mobilizou-se também um desejo de "autonomia". Um desejo mobilizado que, ao que tudo indica, nunca foi realizado completamente.

Perg.: Mas por que vocês saíram daqui (Glicério)?

Nós saímos daqui, primeiro, porque nós precisávamos de um espaço melhor de trabalho, na verdade um espaço para nós mesmos. Aí também queríamos nos desligar da OAF. Não que a OAF fosse ruim, assim, mas a gente queria ter autonomia. A OAF era uma coisa e a cooperativa era outra. Mas acho que até hoje a gente não conseguiu. A gente queria desligar um pouco da "mãe" e tinha uma alternativa lá em Pinheiros. Mas não foi bem desligado. Saímos daqui e fomos lá para Pinheiros com a gestão Erundina. Foi duro sair daqui. A gente pensava que ia conseguir, mas foi difícil, não conseguimos caminhar sozinhos e tal. Mas foi uma boa, a gente conseguiu um espaço lá em Pinheiros.

A formalização dos catadores em cooperativa e o distanciamento em relação à sua "mãe" gestora colocam novas dificuldades no trabalho. Dificuldades que implicam na necessidade constante destes trabalhadores se dedicarem e se remeterem permanentemente aos empecilhos próprios de uma linguagem administrativa e burocrática. Além de desenvolverem diariamente suas árduas tarefas de "puxar carroça" e manusearem artefatos urbanos rejeitados e saturados de significados como impureza e perigo, estes trabalhadores agora têm de se embrenhar e decifrar todo um conjunto lexical que não é próprio a seus domínios e que, contudo, faz parte dos trâmites necessários à manutenção da "pequena empresa coletiva que é a cooperativa". E é no difícil manuseio da linguagem técnica, bem 
como na necessidade de apoio através de recursos públicos que a presença da OAF se faz até hoje na cooperativa. Contudo, esta alteração do poder municipal, que inflectiu na trajetória de Carlinhos e dos catadores que o acompanham, também produziu efeitos variados em todo campo de relações que gravitavam em torno do mundo da rua. E é justamente neste momento, quando o poder público se aproxima seriamente deste universo, que a história aqui contada tem sua trama redefinida.

A entrada em cena do Estado nesta configuração de forças altera radicalmente as regras do jogo. Sua presença institucionaliza certas práticas já existentes, bem como promove uma descontinuidade, com relação a maneiras de agir e pensar que então prevaleciam. Não que o poder público não tivesse nenhuma relação com aquilo que acontecia neste universo, pois na verdade as condições de ordenamento destas relações se faziam também como resultado de sua própria ausência. Entretanto, como veremos, é a inserção da prefeitura neste campo social, a partir da construção de uma linguagem comum para a intervenção, que intensifica certos processos e produz um alongamento das cadeias de interdependência nas quais estes agentes então se situavam ${ }^{21}$.

\subsubsection{Alderon $^{22}$}

A singularidade da longa trajetória de Alderon neste campo de relações vincula-se, entre outras coisas, ao seu importante papel desempenhado no desenvolvimento de novos meios de comunicação e, portanto, de publicização da questão. Hoje, Alderon é editor do jornal $O$ Trecheiro e membro diretor da Associação Rede Rua, contudo até chegar aí, muita coisa aconteceu e vale a pena contar parte desta história. A entrevista, cordialmente cedida, durou mais de duas horas e ocorreu na sede da Associação Rede Rua.

Alderon veio de Brasília, mais precisamente de uma cidade satélite chamada Ceilândia Norte, que na época era considerada uma favela, "uma grande favela". E com um grupo de

\footnotetext{
${ }^{21}$ Contudo e apesar de tudo, mesmo se aceitando a eficácia dos poderes emanados da instituição-Estado, é necessário explicar seu funcionamento. E o poder da máquina estatal pode ser analisado através de feixes de mediações que articulam perspectivas e micro-diferenças, que constituem os próprios pontos de apoio dos poderes públicos e suas práticas oficiosas. Como nos diz Jacques Revel a respeito da análise de processos políticos, "mesmo ao se admitir a hipótese de uma eficácia global dos aparelhos e das autoridades, falta entender inteiramente como essa eficácia foi possível - ou seja, como foram retranscritas, em contextos indefinidamente variáveis e heterogêneos, as injunções do poder" (Revel, 29:1996b). Assim, não querendo decifrar "o Estado", tampouco duvidar de sua potência política, apreciar-se-á alguns desdobramentos específicos de sua ação, através de cenários localizados e pontos muitos circunscritos nos quais as trajetórias aqui analisadas atravessam. E isto visando recompor parcialmente modalidades de apropriação, circulação e negociação, de maneira e vislumbrar nestes procedimentos certos efeitos de poder, resultantes da proximidade desta nova prefeitura com lógicas particulares e imanentes a este campo social.

${ }_{22}$ Alderon Pereira da Costa foi entrevistado em 06/10/2006
} 
jovens de lá, já era envolvido com "trabalhos comunitários" e com a "luta pelos direitos, pela água, pela luz”. A mudança para São Paulo se dá no começo de 1982, justamente em sua entrada no mundo adulto, quando então completava seus 19 anos. Chega aqui com uma intenção muito clara: "eu vim na verdade com o objetivo de estudar e entrar no seminário, ia ser padre". O deslocamento de Alderon para a capital paulista agencia uma importante transformação em sua trajetória pessoal, desenha uma dobra em sua linha de vida. É nesta passagem em curva, quando outros contornos começam a se delinear em seu itinerário, que tem contato com toda uma gama de novas realidades que passam a ecoar em sua experiência, fazendo parte dela e alterando-a. Realidade geracional, pois se torna um adulto; realidade intelectual, pois tem contato com formas de pensamento e conhecimento até então não experimentadas; realidade política e urbana, pois em São Paulo a desigualdade social e seus conflitos acirrados assumem escalas muito mais dilatadas que em Brasília. Estas novas e truncadas realidades vividas por Alderon acompanham também novas modalidades de questionamento e interpretação do mundo. Entra na faculdade, começa a fazer o seminário e logo vê que tem de "ralar um bocado" para acompanhar o curso, seu estudo anterior era fraco e não estava acostumado com o denso e intenso ritmo de leitura e debate imposto. E é aí, nesta faculdade jesuíta, que tem contato direto com ao pensamento marxista, a teologia da libertação e toda uma discussão sobre a "opção preferencial pelos pobres".

Toda uma efervescência política de uma época o pega em cheio e provoca, como ele mesmo diz, um "choque de realidade". Tudo muito novo: o crescimento periférico da cidade de São Paulo, as lutas operárias, as Comunidades Eclesiais de Base, a teologia da libertação, sem falar "na pobreza exposta na rua". Seu regime de vida também não era um dos mais tranqüilos, já que no primeiro ano teve de "correr atrás do tempo perdido", estudando um bocado e ao mesmo tempo trabalhando numa "comunidade". Contudo, esta comunidade que participava lhe pareceu já muito arrumada, “já tinha uma vida própria, uma estrutura, eram pessoas que não eram ricas, mas tinham a sua situação estabilizada, e eu me senti um pouco perdido dentro de tudo isso". Depois de um ano ali, decide ir à procura de outro trabalho e de outra experiência, como os famosos "espaços operários" da Zona Leste e do ABC. Estes territórios contestados pelos célebres movimentos de trabalhadores, onde se redesenhavam novas modalidades de luta social, eram carregados de significação política, neste momento histórico de turbulenta transformação brasileira que ficara conhecido como "processo de democratização": 
Fui atrás dos espaços operários em Santo André. Aí a gente visitou umas comunidades, a comunidade de Nova York, que era periferia ali da zona leste. Bom, fui conhecendo várias outras experiências. E não achei algo mais assim... e fiquei ainda meio angustiado, mas aí um dia eu entrei na livraria das Paulinas, hoje chamado Paulus, do lado da catedral (da Sé). Aí vasculhando os livros, encontrei um livro chamado "Somos um povo que quer viver", aí peguei o livro. Fui de férias para casa em janeiro e aí lá tinha muito tempo, peguei e li o livro, e me encantei com esse livro, porque é um livro que me encantou pela experiência da sopa. A experiência da sopa foi assim marcante para mim. Quer dizer e ela contada no livro, ela é fantástica aquele relato, eu realmente admiro muito, e dali em diante eu falei... vim para São Paulo, voltei pro segundo ano, decidido, vou procurar esse grupo, vou ver se é possível participar e colaborar de alguma forma.

Já embebido por toda uma pluralidade de "combustíveis" religiosos e políticos, a leitura de Somos um povo que quer viver entra em ressonância direta com uma série de referências, materiais e formas simbólicas que já operavam nos processos de subjetivação vividos por Alderon. No meio de "toda aquela vontade de busca", como narra, o livro organizado por Nenuca é precisamente o agenciamento catalisador que vai estabelecer as conexões capazes de entrelaçar a trajetória de Alderon com a trajetória da própria OAF, suas Oblatas, seus participantes e suas múltiplas atividades e desdobramentos. Este livro é aquilo que incita e suscita o enlace e o desejo de Alderon junto ao universo da rua, mediando, recrutando e introduzindo-o no interior de um pólo embrionário de gravitação em torno do qual, posteriormente, irão girar numerosos discursos, práticas e técnicas institucionais. Depois de um período de formação, que durou uns quatro domingos, Alderon se insere dentro das atividades da OAF e da Comunidade dos Sofredores de Rua, que se reconfigurava neste momento, segundo três agrupamentos de trabalho e ação no centro de São Paulo:

Tinha o grupo da Luz, com a Cristina e o Roberval, tinha o grupo do Parque Dom Pedro, coordenava o Luís Kohara e a Maria Isabel, e no Glicério, a Regina e a Ivete. Eram três grupos, um foi para o Parque Dom Pedro, o outro ficou na Luz (...) e indicaram então que eu fosse para o Glicério, aí fui para o Glicério.

Por dois anos Alderon freqüentou este universo de relações pelos menos duas vezes por semana, já que tinha outros compromissos que também demandavam tempo e esforços, como os estudos e sua própria congregação. Aos domingos freqüentava a Casa de Oração, "espaço de troca e espiritualidade", que na época já se localizava próximo ao Largo São 
Francisco, e às quartas-feiras acompanhava a sopa debaixo do viaduto do Glicério, onde se juntava a comida "um pouco dali e daqui, e se comia junto com todo mundo". Depois da sopa, havia uma reunião numa das "casinhas ali do Glicério" e faziam discussões, reuniões e conversas coletivas. E numa destas "casinhas", Alderon começou a dormir, primeiro, nos finais de semana, e depois, durante seis meses seguidos, com o intuito de levar a sério a proposta de "simplesmente conviver com as pessoas". Mas suas atividades também lidavam com as urgências do cotidiano, que volta e meia apareciam por ali, como os eventos de morte na rua que mobilizavam ações, assim como também se envolvia com a organização coletiva da Missão:

\begin{abstract}
Existia nesse período, inclusive uma coisa muito forte, que eram os enterros. Morria muita gente na rua, e na Comunidade (dos Sofredores) a gente enterrava muita gente, porque eram amigos da Comunidade. E como não tinham albergues, não tinham coisas assim, as pessoas morriam na rua e ficavam, e a gente acompanhava tudo isso. A Comunidade ia lá no IML, não é? Eu fui umas duas vezes ou três, acho que a Regina também já foi, bom, a gente toda hora tinha que ir, e era muito forte para essa população, uma frase que eu ouvi de uma pessoa da rua uma vez, ele falou para mim: "Olha, eu fico impressionado, porque vocês cuidam tão bem dos mortos, imagine o quê que vocês não fariam por nós, vivos" (...).
\end{abstract}

Participantes da OAF e freqüentadores da sopa e das reuniões do Glicério acabaram por ocupar uma casa que estava abandonada e em condições bem precárias. E esta casa foi utilizada de diversas maneiras, como espaço para mais reuniões, ensaios de teatro e também como moradia para Alderon. Ao narrar as dificuldades e experiências de trabalho com esta população, a narrativa de Alderon articula um volteio temporal ao retomar um importante elemento do passado (que o acompanhará em toda sua trajetória), a fim de conectá-lo ativamente no atual andamento de seu relato: a fotografia:

(...) mas seria interessante voltar um pouquinho aí, antes, só para dizer assim, a minha profissão é sempre ligada à fotografia, eu trabalho há muito tempo com fotografia, desde os catorze anos, quando trabalhei em laboratório fotográfico, trabalhei na Kodak, fazia correção de cor. E no primeiro ano (em São Paulo) eu abandonei tudo, mas tinha uma maquininha. Mas mesmo assim não tinha dinheiro para comprar filme, que era uma vida bem regrada também. A gente tinha tudo, a comida, livros, tudo, mas dinheiro no bolso, não tinha. E aí eu abandonei um pouco isso, mas lá na Comunidade (dos Sofredores de Rua), eu comecei a perceber que eu podia usar um pouco esse dom que eu tinha, que eu aprendi, desenvolvi, 
que é a fotografia. Comecei a tirar algumas fotos e começamos a perceber que era importante dar o retorno para as pessoas. Conseguimos um projetor, então a gente começou a fazer filminhos. Fotografava o passeio, por exemplo, aí no outro encontro a gente mostrava aquilo ali para o pessoal, era uma motivação de integração. E a gente percebia como as pessoas gostavam de se olhar, e ao mesmo tempo também, a gente começou a criar uma memória. De repente, a gente via uma foto de uma pessoa que estava totalmente caída. E daqui a pouco a mesma pessoa foi para uma praia, voltou melhor, o cara estava bem, então ele via essas diferenças e mudanças. Até de propósito às vezes, a gente fazia alguns conjuntos de imagens. Era um período em que a gente estava descobrindo formas de trabalhar com o povo, lidar com a questão das dinâmicas, porque era difícil para gente se comunicar com a população (...).

Aí eu comecei também a usar um pouco esse, vamos dizer assim, esse carisma que eu fui desenvolvendo, que era a questão da fotografia, também da arte em si, do teatro, a gente foi fazendo um pouco de tudo. Desenvolvemos alguns áudios visuais e para isso pegava muito equipamento emprestado.

Na busca por novas linguagens de relação com estas pessoas, a fotografia, este "dom" e "carisma" como nos fala Alderon, passa a ser um canal de comunicação privilegiado. $\mathrm{Na}$ procura por novas formas de abordagem, trabalho e contato com esta população de características tão específicas, a fotografia, o filme e o exercício de reflexão sobre as imagens registradas passam a ser uma maneira diferencial de estabelecer vínculos, já que se pautam por um modo de interação não assentado unicamente na relação fala-escuta, onde normalmente a autoridade tem o poder da fala e o educando o dever da escuta. Como nos explica Alderon:

As pessoas não agüentavam ficar ouvindo. Até pela característica, pela dispersão, por tudo, então como a gente vai falar com eles, não é? Então era essa discussão. A gente começou a criar várias outras formas de falar: o teatro, a música, as imagens e as dinâmicas. Tinham muitas dinâmicas de integração, onde eles contavam histórias. A gente os motivava a contar histórias. Tinha um bonequinho que a gente passava de mão em mão, e o bonequinho era ele mesmo! Quem contava a história era quem segurava o boneco. Saíam coisas maravilhosas. Era muito intenso todas essas questões e a gente acreditava ainda que podia transformar o mundo. Acreditávamos nesta coisa de louco. Pensar que aquela população poderia também colaborar nessa transformação do mundo, isso para nós era, assim, uma coisa muito clara. E íamos contra a corrente. Porque todo mundo achava que isso era loucura, "como esse povo bêbado, vai poder colaborar com isso?" Aí tinha discussões e discussões em cima dessa 
questão. Não em cima assim, mas na borda, na prática, porque nós acreditávamos nisso, sem discutir a gente acreditava. E tinha todo o movimento de São Bernardo, dos metalúrgicos, que era forte. Coisa assim, a revolução vai vir, a transformação social e tudo mais. Mas era tudo lá, era paro lado de lá. Mas enfim, a gente acreditava e apostava muito nessa transformação, pouco a pouco, passo a passo, e principalmente porque a gente não acreditava muito numa sociedade que não incluísse essa população, quer dizer, que sociedade é essa que não pode incluir esta gente? Para se ter uma sociedade diferente, tem que incluir essa população e nós temos que estar preparados para isso.

Nestas atividades e dinâmicas, todo um jogo de expectativas envolvia-se com planos de ação coletiva, que ocorriam em outras partes da cidade e em outros lugares. Em torno do desejo de transformação social - desejo muito específico de um tempo e um espaço que via nesta transformação algo como um horizonte, no mínimo, tangível - articulavam-se uma miríade de agenciamentos diferenciais, que estabeleciam elos uns com outros, ligações travadas não sem conflitos e desacordos ideológicos. Assim, o trabalho desenvolvido com as pessoas vindas das ruas conectava-se diretamente com as profusões políticas e ebulições desejantes de uma época que, no entanto, dificultava a assimilação de práticas mais heterodoxas em seu bojo e tendia a repelir as vozes menores e mais dissonantes. Como então incorporar o "lupemproletariado", o ruído e o resíduo da classe trabalhadora, neste processo? Apesar desta ser, como nos fala Alderon, uma questão muito discutida, a proposta do trabalho não era tirá-los da rua, para então promover alguma transformação:

Em função de tudo isso, a gente era muito livre. Nós não estávamos preocupados em tirar as pessoas da rua. O que nós queríamos na verdade era possibilitar um espaço para ela, que se ela quiser sair, ela tem esse espaço. A gente poderia colaborar nisso, nós éramos meros colaboradores deles. Tanto que nós íamos dormir na rua, era um período em que eu cheguei a dormir na rua. Só para estar junto com eles, tinha mais essa característica o trabalho, o estar muito junto com as pessoas. E a idéia era assim: "bom, a partir do momento que a gente está junto, a pessoa também se sente mais valorizada e daí a transformação vem” (...) Tínhamos convivências muito intensas. Desde convivências boas, como amargas. Porque às vezes a pessoa ia colocar a faca no seu pescoço, e nós trabalhávamos com uma metodologia, que até hoje eu defendo, que não é a metodologia de ficar passando a mão no coitadinho. A gente teve sempre muito claro que tinha que provocar as pessoas e confrontar as pessoas. E nesses confrontos, de vez em quanto a gente tinha uns confrontos reais. 
Neste cotidiano de urgência as coisas nem sempre corriam muito bem. Como as situações eram muito instáveis e intensas, as tensões latentes algumas vezes eclodiam como confrontos reais, brigas, facas e ameaças. No entanto, esta intensidade (ainda que potencialmente explosiva) adquire um sentido muito positivo na narrativa de Alderon. $\mathrm{Na}$ organização de seu relato, esta passagem pela Comunidade do Glicério, pela OAF, e seu envolvimento direto com a rua, é narrada como um período marcante em sua vida, um momento de grande intensidade, forte experiência e vivência, intensa troca e aprendizado. Aprendizado de sutis maneiras de fazer e modos de lidar, saberes locais e singulares que carregará consigo, articulando-os em seu percurso e acionado-os de modos variados em outras ocasiões e situações, em outros tempos e espaços.

Depois deste período Alderon encerra temporariamente seus trabalhos na Comunidade dos Sofredores de Rua, pois tem de voltar à Brasília para o noviciato, uma etapa na formação para a vida religiosa. E mesmo ali, durante um ano, investe mais ainda na "área da cultura popular" e não se desvincula de suas relações estabelecidas na capital paulistana. Em 1986, ao retornar para São Paulo vai morar em Pirituba e continua estudando teologia. Consegue autorização de sua congregação para retomar suas atividades no Glicério e na sopa. Neste período a OAF conseguira uma verba para comprar a casa onde até hoje é sua sede.

O pessoal ajudou e... foi todo mundo assim, aí começou uma mudança, eu acho que aí é o... vamos dizer assim, o marco de uma outra etapa na comunidade. Mesmo com algumas características, começa uma estrutura um pouco maior, porque começa a crescer também.

Perg.: E não tinha apoio do poder público na época?

Não, não tinha, porque o grupo tinha uma outra visão, tinha saído de uma institucionalização muito forte (...) A idéia era as pessoas terem que ter relações diretas com as pessoas da rua, nós não podemos ser intermediários, inclusive com roupas, essas coisas. Eu acompanhei uma vez a (Irmã) Ivete falando para uma senhora lá que chegou para doar roupa: "Por que que a senhora mesmo não vai lá entregar, por que que nós temos que entregar?". Então era uma coisa muito interessante nesse sentido de possibilitar às pessoas um contato direto com a realidade. Quebrar os preconceitos e tudo mais. E inclusive doações, projetos, essa coisa, não tinha muito essa discussão não, era tudo muito pequeno. A gente vivia com o pessoal. Íamos para a feira catar mamão, fazer vitamina, as festas de aniversario eram todas feitas a partir da rua mesmo, era um negócio bem pequeno. Não dá para comparar com hoje. 
Realmente não dá para comparar com os dias atuais, mais de vinte anos depois, quando a questão se amplia, se complexifica mais, e toda uma intrincada maquinaria institucional passa a colonizar o tema. Contudo, esta comparação e o cotejo das diferenças de abordagem são também inevitáveis, pois geram um enorme estranhamento, chegando a produzir uma sucessão de imagens nostálgicas, senão idealizadas, sobre os "bons momentos" que já se foram e não voltam mais. Estas relações e formas de trabalho, que como vimos não estavam sós e acompanhavam toda ebulição de um momento de nossa história, distinguiam-se muito dos "projetos sociais" que hoje proliferam em torno dos chamados excluídos. Claro que a escala do problema bem como os ideais que mobilizavam as forças que faziam todas estas ações interagirem eram também outros. É indiscutível que este conjunto de experiências de trabalho e convívio desprendido, próximo com os então sofredores de rua, possui uma forte carga religiosa. Ao identificar na experiência de rua a negação do mundo material e capitalista, como seus participantes narram, foi possível significar no sofrimento da rua a existência e resistência de um valor divino transcendental. Como a presença de Deus se fazia na rua junto aos pobres, aproximar-se dali era aproximar-se do próprio Criador. Aquele trabalho, não à toa, era visto como uma verdadeira Missão, ou então, como o próprio Alderon nos conta, "era algo verdadeiramente profético".

A segunda metade da década de 1980 configura-se enquanto o início de um novo tempo na trajetória da $\mathrm{OAF}$, nas modalidades práticas junto à rua e no percurso deste universo de relações. Os participantes da Comunidade dos Sofredores de Rua ocupam uma outra casa abandonada no Glicério e logo depois de tudo arrumado, "aparece o dono rapidamente para reclamar". E depois de um esforço, a organização consegue comprar esta casa e as atividades desenvolvidas começam a se circunscrever mais detidamente na região do Glicério. Segundo Alderon, a compra desta casa "foi um marco de mudanças" e a partir daí tudo tem de se organizar um pouco mais, "tem de ser mais planejado". Ao mesmo tempo em que Alderon começa a se envolver, aprofundar e se "integrar um pouco mais na estrutura da organização", um movimento de disseminação e dispersão dos participantes e colaboradores obriga um rearranjo das relações:

Então começa a ter uns rachas. É nesta época que sai o Luíz Kohara e o Roberval (...) E aí me parece que começa a haver alguns problemas. Depois a Amélia parece que se casa e sai também. Inclusive ela se casa com uma pessoa que era da rua também. E depois a Cristina vai para Belo Horizonte e depois a Fortunata também vai. Bom, e aí a gente continuou o trabalho porque a comunidade do Glicério, o grupo do Glicério que a gente chamava, é um 
grupo que foi avançando. Pode se dizer que, dos três grupos que a OAF tinha, o único que ficou foi o grupo do Glicério.

Encruzilhadas e entroncamentos que insurgem no horizonte deste coletivo: novos pertencimentos, outras chamadas, tensões latentes que eclodem. Todos estes enlaces, "casamentos" e "rachas", agenciam uma disseminação dos membros que compunham aquela antiga ordem de relações. Daquelas três bases de trabalho, que estrategicamente distribuíamse pelo centro de São Paulo, apenas resta o Glicério, além da Casa de Oração.

Exatamente um ano antes de Luiza Erundina assumir a prefeitura de São Paulo, Alderon passava por um momento de profunda turbulência em sua vida. Ele conta que depois de refletir sobre sua experiência, resolve sair do seminário e da congregação da qual era membro. E como vivia em sua congregação, perde sua antiga moradia. Apesar de ter se afastado do seminário e abandonado o projeto de vida no qual até então tinha se engajado, permanece o sentimento de que "tinha um compromisso com o Povo". É então acolhido na Comunidade dos Sofredores de Rua e passa a dormir na parte de cima da casa, onde também funciona a Associação dos Catadores. Lá mora por menos de um ano. É contratado e registrado como funcionário da OAF. E junto com outra pessoa que também vivia lá, faz um projeto, "inclusive acho que foi o primeiro projeto de comunicação para a população de rua". Nesta passagem, sua narrativa apresenta um forte tom reflexivo, ao expor este período de sua vida como um difícil momento:

Aí no final de 88 eu tive uns contratempos lá na comunidade e aí eu resolvi me desligar. Pedi demissão da OAF e pedi para sair. Passei um período bem barra pesada, uns três meses. Porque assim que eu saí da $O A F$, eu tive que sair da comunidade porque é também um pouco a pedagogia do trabalho. Enisso elas são muito objetivas. Deve ter sido muito duro para elas também, eu sei como é que é isso, você tem que ter clareza nos objetivos. Tive de sair dentro de um mês e fui morar numa escola. Uma conhecida tinha uma escola de deficientes, com Síndrome de Down, e a escola só funcionava de manhã, então ela me emprestou a casa: "Olha você pode ficar na casa, à noite não tem ninguém, aí você põe um colchão e dorme". Aí fiquei morando nessa casa.

Este momento reflete outro ponto de inflexão no itinerário, que Alderon foi delineando ao longo de sua biografia. Ao desistir de ser Padre, todo um repertório de vida acumulado se vê sob suspensão. Logo em seguida se distancia da OAF, ficando novamente sem renda e sem ter onde dormir. A suspensão torna-se indeterminação. Aí vemos uma descontinuidade na 
trajetória de Alderon. Não uma quebra, mas sim um deslocamento em sua trajetória, deslocamento marcado pelo signo da incerteza e da crise, um período "bem barra pesada" como ele mesmo nos diz. No entanto, são justamente estas curvaturas, situadas nas perigosas e turbulentas encruzilhadas da vida, que, embaraçando e desarranjando as relações anteriores, permitem redefinir práticas antigas, inaugurando novos caminhos para outros rumos e possibilidades até então não imaginadas.

Morando nesta escola por três meses e com a situação financeira cada vez pior, Alderon busca trabalho em vários cantos da cidade, até que consegue um emprego como técnico audiovisual na USP: "O trabalho era bom, o serviço era fácil" e, além disso, abriu a ele a possibilidade de fazer outros cursos. Nestes cursos aproximou-se mais das técnicas de áudio-visual e das discussões sobre comunicação popular, "porque na época não se falava muito em comunicação alternativa, a discussão era comunicação popular”. Em 1990, Padre Arlindo o procura com uma proposta. Já eram amigos de antes, quando Arlindo tinha interesse em trabalhar com eles na Comunidade dos Sofredores de Rua. Contudo, os desatinos da história fizeram com que "no dia em que ele foi para lá, eu saí de lá. Ele levou um susto, ficou 'pê' da vida comigo". E neste período em que Alderon estava fora da OAF, Arlindo criou o "Jornal da Rua", projeto que ele e Alderon haviam planejado juntos.

Padre Arlindo também havia então saído da Comunidade e apresentava uma proposta que a prefeitura tinha feito, de abrir e coordenar um serviço para a população de rua no Brás. Assim, Alderon, Arlindo e mais dois outros conhecidos colocam-se perante a proposta: "Nós assumimos alguns trabalhos, desde que seja possível ter um centro de comunicação também”. A prefeitura aceita a proposta e aqui a trajetória de Alderon começa a se articular com outras trajetórias e pessoas que juntos fundam CDCM - Centro de Documentação e Comunicação. Ocorre que como não havia muitas organizações com experiência neste trabalho, tampouco havia qualquer referência institucionalizada para lidar com a questão, estas novas políticas tiveram de se pautar pelos saberes locais existentes, apesar de não formalizados, hierarquizados ou integrados em conjuntos funcionais sistemáticos. Neste período é que se inicia a apropriação, transformação e institucionalização de práticas e saberes singulares que já existiam. E entre estas práticas se encontravam as atividades desenvolvidas pela OAF, as Oblatas e seus colaboradores, que se tornaram a principal referência sobre esta população.

Surpreendendo os índices do IBOPE e as expectativas gerais que se tinha na época, Luiza Erundina ganha a eleição para a prefeitura de São Paulo e esta imprevista vitória, além de alterar potencialmente o universo das práticas e relações envolvidas com a rua, gerou toda uma reconfiguração nos horizontes de possibilidades das organizações populares da cidade. 
Este governo lançou para o interior da máquina pública municipal uma série de questões sociais, que até então haviam sido discutidas e debatidas longe do Estado. E uma das questões que são lançadas para o interior da prefeitura é a da rua. Mas se é verdade que a nova prefeita já conhecia um pouco do universo da rua, por suas incursões na Baixada do Glicério e seu apoio aos catadores, também é verdade que a rua chegava cotidianamente à prefeitura (como provavelmente também acontecia na gestão anterior), sob a forma de reclamações e queixas. Eram ligações telefônicas, cartas, ofícios e inúmeras solicitações com o mesmo objetivo: "remover as pessoas das ruas" (Vieira, Bezerra \& Rosa,1992:134).

No entanto, não se sabia quem eram estas pessoas da rua, quantas eram, de onde vinham, o que faziam e, o mais importante de tudo, não se sabia o que se deveria fazer com toda esta população. As ações institucionais existentes não davam conta da enorme demanda, além de não serem consideradas ações especializadas para tratar deste público tão peculiar. Impunha-se, então, a necessidade de se conhecer este universo e estabelecer estratégias específicas para lidar com esta população, que então começava a tornar-se um importante dilema para a administração do espaço público no centro da cidade. A partir daí, começa-se a tentar construir conhecimento compartilhado sobre esta população, conhecimento que se dá através dos diálogos estabelecidos com as organizações e pessoas que já possuíam uma experiência com este universo. E é assim que o Estado começa a se conectar diretamente com algumas das trajetórias aqui expostas, suscitando o entrecruzamento com outras trajetórias e fazendo surgir novos personagens neste cenário.

Na época, a então supervisora regional da Secretaria Municipal do Bem-Estar Social (região Sé-Lapa) Cleisa Maffei Rosa organizou um Fórum Coordenador dos Trabalhos com a população de rua. Uma das propostas iniciais deste Fórum era justamente a de debater as diferentes experiências de trabalho aplicadas com as pessoas de rua e discutir de que maneira tais abordagens e serviços poderiam tornar-se políticas públicas. E neste processo, foi se construindo paulatinamente uma linguagem comum capaz de articular uma gramática de relações entre poder público, organizações religiosas e experiências de rua. É no interior deste Fórum que a categoria população de rua começa a ser mais manuseada pelos operadores políticos, categoria essa que até então era utilizada pelas Oblatas apenas para referir-se a um conjunto bem mais amplo de perfis sociais que, além dos chamados mendigos, englobavam também “prostitutas, alcoólatras, migrantes, recém-chegados, psicopatas, egressos de prisão, menores abandonados" (Rosa,2005:52). Neste processo de invenção da política e de construção de um conhecimento comum, as formas e elementos passados tornam-se os pilares das ações que começaram a serem empreendidas. Assim, o Centro Comunitário do Glicério 
torna-se o modelo das casas de convivência implantadas pela prefeitura. As acolhidas de frio, quando no inverno se abria a Casa de Oração para receber os moradores de rua, também se transformam numa política pública. Outro modo de ação existente e que neste momento se institucionaliza como política é o albergue. Esta instituição já existia, mas até então não era vista como um serviço específico para este público, e a partir desta gestão o albergue começa a ser mais seriamente visto como uma moradia emergencial para um contingente populacional sem casa. É neste contexto que Alderon retoma suas relações junto ao universo da rua, relações que são articuladas através da casa de convivência que sua entidade começa a coordenar, com o convênio da prefeitura, mas principalmente através do centro de comunicação que ele ajuda a fundar:

Montamos o Centro de Comunicação, só que não tinha onde funcionar. Aí começamos a
buscar lugar, porque também não tínhamos dinheiro para pagar aluguel. A prefeitura era
muito clara, três funcionários, dinheiro para comprar o material e era só isso. Aí
conseguimos com um padre uma torre de igreja do Brás, que estava vazia (...)
E nós assumimos, fizemos um mutirão, limpamos tudo e começamos a organizar lá. O
primeiro salão (da torre) ficou para reuniões. Outras duas salas eram da redação, tinha uma
máquina elétrica de ponta, era top de linha na época. Com ela a gente fazia o jornal (...),
datilografava os textos, recortava e ia montando, depois xerocava. O Trecheiro no começo
era assim. Também a gente criou um laboratório fotográfico, a gente tinha um laboratório
dentro da torre, uma das salas era um laboratório fotográfico preto e branco. A gente
fotografava, revelava lá mesmo, fazia tudo lá, aí depois mais para frente a gente conseguimos
um equipamento de vídeo. E o Primeiro Dia de Luta da População de Rua, nós temos
gravado (...) Bom, o centro funcionou, a gente foi crescendo. Depois construímos uma ilha de edição com dois vídeos, tudo muito alternativo. Eram dois vídeos, corte seco, ali mesmo. Na parte de cima da torre construímos um estudiozinho. E fazíamos todo Jornal lá na torre mesmo.

A obtenção de espaço, materiais, máquinas e equipamentos técnicos, bem como o salário de três funcionários qualificados para o trabalho possibilitou a criação do CDCM, Centro de Documentação e Comunicação dos Marginalizados. Marginalizados, pois "era assim que a gente falava na época". Depois de tudo instalado, em agosto de 1991 é lançado o primeiro número de $O$ Trecheiro, "já substituindo o Jornal da Rua", que com o tempo vai se tornando o principal meio de comunicação nesta constelação especializada de laços sociais e que circula neste universo até os dias de hoje. A aquisição de toda uma aparelhagem muda o 
campo de ação e interlocução em que as entrecruzadas trajetórias de Alderon e de outros atores atravessavam. Mas como "as máquinas não explicam nada, é preciso analisar os agenciamentos coletivos dos quais elas são apenas uma parte" (Deleuze, 2006:216). E as máquinas do CDCM estavam diretamente envolvidas com a luta social dos marginalizados e da população de rua ${ }^{23}$.

Em maio de 1991 é efetuado o primeiro Dia de Luta da População de Rua, manifestação que vai até a Câmara Municipal. É entregue uma carta aberta, exigindo do poder público direitos básicos para a população de rua, como moradias coletivas, atendimento médico sem discriminação, alojamento durante o inverno, tratamento digno e sem violência policial (Domingues Jr., 2003). A partir de então, a questão da rua foi se politizando cada vez mais, de tal modo que gradativamente a Missão, prática estimulada pela OAF na década passada, deixa de existir, e o Dia de Luta, enquanto momento de reivindicação, ganha mais força, passando a ocorrer todo mês de maio. E o Centro de Documentação, com o tempo, vai adquirindo um importante papel de articulação, divulgação e apoio em outras manifestações políticas, ajudando e emprestando seu equipamento a comícios e outros eventos articulados às mobilizações sociais do período. Ao engajar novas tecnologias de comunicação nas lutas sociais, o CDCM possibilitou ampliar o horizonte de diálogo, atuação e interlocução com as questões políticas prementes à época, e em especial, em relação à população de rua. Ao perguntar a Alderon sobre a proposta e o que eles "tinham na cabeça com este centro de comunicação", ele me responde:

O que eu tinha na cabeça era assim, primeiro era produzir algum material para discutir com a população, e outra questão era documentar a história da população de rua. Mas a gente percebeu que precisaria de muito mais estrutura para fazer uma documentação mais precisa. Mas aí começamos a desenvolver trabalhos na rua, fazer reuniões na rua, na casa de convivência, a gente tinha um som comunitário. Eram duas caixas de som que, por exemplo: se o pessoal ia ter uma festa, a gente emprestava, a gente levava, se ia ter algum comício, a gente colocava na Kombi, a gente tinha uma Kombi. Então era um pouco esse apoio aos trabalhos e aos movimentos. Já nessa época dos movimentos sociais, também. tinha a

\footnotetext{
${ }^{23}$ Logo no primeiro número do Jornal $O$ Trecheiro, seus objetivos são anunciados: "1º Estar presente nas situações de conflitos, transformando-se em Notícia-denúncia e anúncio das realidades vividas pelo povo marginalizado, confrontando com a ideologia do poder normalmente veiculada pelos grandes meios de comunicação. $2^{\circ}$ Ouvir, ver e sentir a realidade vivida por esta população, transformá-la em notícia, e promover sua veiculação nos meios de comunicação já existentes. $3^{\circ}$ Propiciar um maior dinamismo e integração entre os movimentos que trabalham com os marginalizados. $4^{\circ}$ Fazer a documentação visual, auditiva e escrita dos momentos mais importantes do dia a dia vividos entre o Povo da Rua e nos diversos movimentos marginalizados" (Jornal O Trecheiro, Agosto de 1991).
} 
Pastoral Social, que era muito forte nesse período, muito organizada também, então apoiávamos esses trabalhos aqui no centro (...) Criamos também o Cine Rua, projetávamos vídeos na rua, tinha um debate, isso vem já bem depois, acho que 93, 92, que aí a gente consegue um telão de três tubos, forte, grande. E então a gente fazia esse trabalho até por conta da questão da Aids também, a gente aproveitou muito esse mote da Aids, para levar filmes para rua, para discutir com o pessoal.

Durante o período de três anos, Alderon permanece trabalhando na USP à tarde e à noite, e de manhã no CDCM. Depois deste período, se demite do trabalho na USP e assume integralmente o Centro de Documentação, localizado na torre da igreja do Brás. Só que "depois com o tempo a gente foi se cansando, porque subir aquela escadaria toda era dose". Posteriormente, conseguem comprar uma casa no Brás, que é a atual sede da organização.

Mas com a saída de Erundina e a entrada da nova prefeitura, o Centro de Documentação fica sem convênio, obrigando a um rearranjo daquelas relações. A alteração dos poderes municipais produz transformações nas condições de convênio com várias entidades e organizações sociais, e estas mudanças também imprimem alterações nas formas de atuação com os usuários dos serviços. A rede de relações que conectam o Estado ao morador de rua assistido é colocada em cheque, e pode se desestabilizar com a erupção dos novos tempos políticos da cidade. Vemos aí como a manutenção de um convênio com a prefeitura depende mais do que simplesmente os "princípios legais" ou as "regras normativas" que regem as relações contratuais. A manutenção deste tipo de relação passa também pela capacidade da entidade de se flexibilizar frente às atuais exigências dos novos operadores políticos e suas transformações, bem como conseguir manter certos elos de afinidade, ou no mínimo, cumplicidade tácita entre os interesses dos gestores públicos e os da instituição candidata ao convênio. Na década de noventa, com o crescimento do chamado terceiro setor e a municipalização dos serviços da assistência social, aparecem novos atores e outras organizações disputando convênios com a prefeitura para cuidar dos assistidos. E em todas estas negociações, a "questão financeira" é um elemento de peso na definição de qual organização consegue e pode se submeter a um convênio:

Depois também um fato que pesou muito para entregar os convênios é a questão financeira. Porque, como hoje, o sistema de convênios é muito injusto com algumas organizações, é um sistema que é feito para grandes organizações (...) Então é muito difícil para pequenas organizações, a gente tem que correr atrás de dinheiro todo mês, para completar a folha de pagamento, os gastos e tudo mais, então tudo isso pesou na hora de entregar o projeto, que a 
gente não estava dando conta mais. Bom, aí nesse período, todos nós assumimos só o projeto de comunicação.

Nestas transações com o poder público, há todo um passe e repasse de verbas, convênios e projetos. Coisas que podem ou não ser passadas. O "passe" adquire aqui um sentido mais simples e, por isso mesmo, mais amplo. O convênio pode passar pela prefeitura, ou seja, ser aceito por um certo sistema técnico de operadores públicos. Mas também pode ser barrado pelos operadores e ser passado para outra organização, que vai continuá-lo e provavelmente mudar suas formas de trabalho. Assim, pela dificuldade do projeto "passar" com a nova prefeitura, a casa de convivência que a entidade coordenava, é "passada" para uma outra congregação religiosa. Já o "Centro de Documentação, ele tinha muita dificuldade de passar, porque eles não queriam que a Secretaria de Assistência financiasse um centro de comunicação". Sem nenhum convênio e, portanto, sem maiores exigências da prefeitura, resolvem mudar o nome do projeto de comunicação. Vemos aí como estes passes e repasses constituem bons elementos para se pensar tanto as continuidades como as mudanças diacrônicas, nesta rede de mediadores e instituições que começam a envolver o morador de rua:

Nós não queríamos esse nome CDCM, mas era uma exigência legal da Prefeitura (gestão Erundina) para poder passar o projeto. Aí então veio a idéia de ter o nome, Rede Rua, porque nós tínhamos muito a intenção de criar uma rede. Inclusive nos primeiros documentos, existia muito esse objetivo: criar rede de relacionamento com outras organizações. Se você olhar os primeiros documentos da Rede Rua, você vai ver isso (...)

No decorrer da década de noventa, Alderon vai desempenhar um importante papel neste campo de relações, que com o tempo vai se politizando cada vez mais. Aos poucos, $O$ Trecheiro torna-se o principal veículo de comunicação neste universo, permitindo um intercâmbio de informações e experiências entre as organizações e entre os próprios moradores de rua. Também nesta década, boa parte das atividades da Rede Rua passa a ser financiada pelo Ministério da Saúde. Só em 2001, com a nova gestão do PT, é que se volta a estabelecer convênios com a prefeitura, assumindo-se a coordenação de um albergue, um núcleo de serviços e moradias provisórias para a população de rua. Vejamos agora outro personagem também atuante neste cenário. 


\subsubsection{Pastora Mabel $^{24}$}

A partir da trajetória da Pastora Mabel, é possível vislumbrar o itinerário diferencial de um ator não filiado à igreja católica e que adentra nesta constelação de vínculos sociais, no exato momento em que estes vínculos estão se institucionalizando e sendo normatizados através dos elos travados com o poder público municipal. A narrativa de Mabel também permite compreender os desafios e as dificuldades cotidianas vividas no interior de uma Casa de Convivência, bem como ilustra certos aspectos dos mecanismos operacionais das parcerias entre poder público e ONGs, justamente num período em que estas começam a ser estimuladas em torno da questão da rua. E é neste período de intensa mudança neste campo de relações, que Mabel entra na trama desta história. Num momento em que a prefeitura e seus agentes públicos estavam tentando estabelecer práticas institucionais capazes de lidar com as questões próprias a um contingente populacional sem casa, que perambulava pelo espaço público da cidade e que aos poucos foi se constituindo enquanto um domínio de ingerência pública. E neste processo de invenção da política e estabelecimento de outras práticas de intervenção social, vai se colocando a necessidade de se instalar serviços de atendimento e buscar entidades e organizações sociais capazes de geri-los.

Natural de São Paulo e de família de religião Batista, Mabel não imaginava seguir a carreira de pastora desde criança. Diferente das Oblatas, o universo religioso no qual Mabel situava-se não possibilitava na época a construção de um desejo de seguir a devoção religiosa. Como ela mesma explica: "Não imaginava ser pastora porque a questão da mulher no pastorado é muito recente. Questão que está mudando, de repente, 10 anos, 30 anos atrás os evangélicos começaram a abrir-se numa perspectiva mais missionária da mulher”. Depois de estudar teologia e assumir o pastorado, Mabel viaja e vive com sua família por vários estados da região Sul do país, já que seu pai era pastor e atuava nessa região. Posteriormente volta para São Paulo para estudar pedagogia, tendo morado no bairro do Belém e depois se instalado em Itaquera, na Zona Leste, bairro em que mora até hoje e onde "eu sempre militei por questões de habitação, numa igreja de periferia onde a gente tem um trabalho social e tal". Enquanto estuda, começa a desenvolver projetos com idosos, crianças e em creches. Neste período, durante toda a década de oitenta, Mabel vai circular entre "comunidades", cortiços, favelas e "bairros da periferia" de São Paulo, trabalhando com este público. E os nomes dos lugares são variados: Favela Monte Azul, Vila Brazilândia, Cachoeirinha e Itapecerica da

\footnotetext{
${ }^{24}$ Mabel Andrade Garcia foi entrevistada em 30/03/2007
} 
Serra. Até que "nossos meninos foram parar na Sé, no Centro. Aí a gente foi se inteirando de outras questões".

As atividades com crianças, que no começo eram voluntárias, tornam-se com o tempo um trabalho fixo. Daí em diante, Mabel permanece como funcionária da AEB (Associação Evangélica Beneficente). Esta instituição, que possui quase oitenta anos de existência e da qual Mabel acompanhou pelo menos vinte e dois anos trabalhando, "não é de uma determinada igreja", como explica, "é uma entidade de filosofia evangélica e que possui apoio da igreja Batista, Presbiteriana e outras denominações evangélicas”. Em 1991 a AEB consegue abrir uma creche no bairro da Liberdade, em parceria com uma igreja protestante coreana local. Só que aquele bairro onde a creche foi inaugurada "não era a Liberdade de verdade, aquilo lá era a Baixada do Glicério”. Não à toa, além da supervisora do Bem-Estar Social da época, Cleisa Maffei Rosa, estar presente, também se encontravam na inauguração da creche, Padre Júlio Lancellotti e a irmã Regina da OAF, personagens ativos na Baixada do Glicério. É nesse dia que tal supervisora faz uma proposta de convênio à AEB, para que a instituição coordene uma casa de convivência.

E aí falamos: "Olha, Cleisa, nossa entidade não tem administração para essa área, não tem vocação nesta área, e o lema da entidade é que 'nos extremos da vida que as pessoas precisam de mais atenção e carinho’”.

Além de "tocarem" na época vários projetos sociais, todos voltados para "os extremos da vida" - juventude e velhice -, acreditavam não ter habilidade para trabalhar com um público tão peculiar como os adultos de rua. Até que outra organização com estreitos elos com a AEB, a AMAS (Associação Metodista Ação Social), faz um convênio com a prefeitura para coordenar um albergue localizado no viaduto Pedroso. Este convênio feito pela AMAS, segundo Mabel, foi um elemento que pressionou a diretoria da AEB a decidir por também abrir um convênio com a prefeitura, para trabalhar com a população de rua. Só que como não tinham conhecimento sobre como gerir uma casa de convivência, tampouco sobre as características deste público alvo, "a gente começou a se reunir e chamou para conversar a irmã Regina, irmã Ivete, Padre Arlindo e Padre Julio”.

A prefeitura disse: "Olha, vocês vão assinar este convênio. Temos um plano de trabalho". Então começamos a conhecer todas as casas (de convivência) e albergues que começavam a ter em São Paulo, que não foi pouco trabalho. Nos deram um monte de modelos, mas não 
gostamos de nenhum. Aí a gente fez um projeto nosso, escrevemos o projeto e colocamos uma equipe para trabalhar aqui (...) E essa casa era totalmente acabada. Não havia portas, janelas, não tinha vaso sanitário, não tinha nada. Uma situação muito triste. Não tinha nada. A gente ficou um pouco chateada, porque saiu o convênio e (a casa) ficou largada. Aqui para roubar é muito fácil, muito fácil, até hoje.

Assumem a Casa de Convivência Porto Seguro em 15 de outubro de 1992, já no final do governo Erundina, quando "existia pressa da prefeitura" em estabelecer os contratos e convênios antes da nova gestão. Só que antes de assumirem a Casa de Convivência, Mabel e outros integrantes da AEB começam a freqüentar os encontros do Fórum Coordenador dos Trabalhos na Secretaria do Bem-Estar Social, do qual então participavam todas as organizações que começam a trabalhar com a população de rua na cidade de São Paulo:

Começamos a participar do Fórum. A gente tinha ficado bem contente de participar, porque todo mundo era bem novato, não no trabalho social, mas na política pública. Do trabalho, a gente entendia que não era tão difícil. Mas dentro da política pública, fazer disso um trabalho para o direito do usuário era outra coisa. Então isso era novo para todo mundo, todo mundo ficou contente, mais confiante. Então o Fórum estava começando (...) A gente estava indo, participando, e a casa (de convivência) começou já com todo mundo junto no Fórum. Foi legal, porque achei que no Fórum ia ter algum preconceito, né? Imagina, o Fórum era da Igreja Católica...

Perg.: A maioria era católica?

Todo mundo era católico! Só tinha padre e freira! Padre, freira e pessoas ligadas à Igreja Católica. E de repente, chega a Metodista (AMAS), com Pastor Samuel e eu com um povo da $A E B$...

Perg.: A senhora achava que teria preconceito?

Eu achei, porque no Fórum da Criança e Adolescente a gente já estava há muito tempo, Fórum da $3^{a}$ Idade também. Mas você ter um Fórum novo, eminentemente católico, é assim, né? Mas foi legal, foi tranqüilo, não teve problemas não. Foi uma coisa que logo entrosou, também o Fórum estava começando, então foi tranqüilo. 
É no interior deste Fórum, organizado pela então supervisora do Bem-Estar Social, Cleisa Maffei Rosa, que é discutida uma pesquisa que se colocava em andamento na época. Com o intuito de apresentar um quadro diagnóstico orientador de práticas políticas, a Prefeitura Municipal de São Paulo encomenda aquilo que se tornou a primeira pesquisa estatística efetuada no Brasil sobre aquela população, que permanecia na sombra e sequer comparecia nos levantamentos nacionais do Censo. Participam desta pesquisa nada mais do que a quase totalidade das organizações sociais que, então, trabalhavam ou começavam a trabalhar com a população de rua. Contudo esta pesquisa só foi publicada, como livro, em 1992, ao término da então gestão municipal. Até porque a "idéia inicial era só ser uma pesquisa mesmo", como nos diz a Pastora Mabel.

Esta obra coletiva, construída no interior do Fórum Coordenador dos Trabalhos (e da qual participaram a AEB, a OAF, a Fraternidade Povo da Rua, o Centro Gaspar Garcia de Direitos Humanos e outras organizações), além de refletir em si mesma um certo retrato deste campo social (com seus atores, posições e relações específicas), é um acontecimento discursivo que vai produzir um importante deslocamento nos antigos modos de apreciação da questão, incitando uma verdadeira ruptura em seu estatuto semântico e político. Mas em que medida esta pesquisa e sua publicação alteram o estatuto da questão?

Primeiramente, ela altera sua escala. Ao redefinir a amplitude numérica desta população, a pesquisa redefine também a escala das práticas e políticas que deveriam ser implementadas. De uma estimativa inicial extremamente vaga, de cinco mil a cem mil pessoas nas ruas de São Paulo, passa-se agora para uma "realidade mensurável" de três mil e trezentas e noventa e duas pessoas nas ruas. Outra importante transformação que esta obra opera no debate passa pela definição mais precisa do tema. A pesquisa mostra que a maioria desta população é constituída por homens que já estão há algum tempo em São Paulo: ao contrário do que se pensava, não são migrantes recém-chegados. Também mostra que esta população sem residência fixa possui uma trajetória de trabalho, apesar de ser uma trajetória profissional segmentada e, muitas vezes, precária.

Estes sujeitos passam, então, a ser reconhecidos como "trabalhadores que não deram certo", uma nova verdade que se instaura e produz efeitos políticos sobre a tradicional e corriqueira acusação moral de "vagabundos", "preguiçosos" ou "gente que não quer trabalhar". A rua como espaço de existência passa, então, a ser interpretada como um modo de vida resultante de uma estratégia de sobrevivência, e não como uma escolha voluntarista de supostos sujeitos desajustados. E a explicação do fenômeno passa a situar-se na desigual estrutura social e no competitivo mercado de trabalho, que seleciona os mais aptos, 
descartando aqueles que não se enquadram (Vieira; Bezerra; Rosa, 1994). Através de referenciais analíticos oriundos de uma teoria social mais crítica e centrada no conceito de trabalho, o mendigo passa, então, a ser visto como um trabalhador irregular e sem um ganho bem definido que, devido a múltiplas determinações de ordem econômica e social, faz da rua seu lugar de abrigo. E nesta virada de perspectiva percebe-se, de maneira mais geral, que a causalidade da situação de rua abandona o sujeito e desloca-se para a estrutura que o coage.

Outro importante enunciado que esta pesquisa vai tornar público refere-se às formas de nomeação do problema, bem como às inovadoras noções manuseadas para análise do tema. A experiência de rua é, então, colocada como principal eixo articulador da heterogeneidade de trajetórias e o grau de aproximação e inserção neste mundo passa a ser o principal critério de diferenciação. São identificadas três situações diferentes em relação à permanência na rua: ficar, estar e ser da rua. Cada uma destas situações corresponderia especificamente a um tipo de vínculo circunstancial, recente ou permanente com a rua. Estas três modalidades de relacionamento com o mundo da rua estariam dispostas num mesmo continuum, "tendo como referência o tempo de rua; à medida que aumenta o tempo, se torna estável a condição de morador" (Vieira, Bezerra \& Rosa, 1994:94). Talvez a mais importante proposição enunciada por esta obra seja justamente a maneira pela qual a questão foi designada. Em verdade, no próprio título do livro é possível ver esta nova titulação, bem como a intenção em definir os termos do debate: População de Rua: Quem é, como vive, como é vista.

Esta obra, ao ser publicada, tornada pública através de um discurso legítimo, ampliou, deu visibilidade e reorganizou a família de significados que até então caracterizavam o tema, mas que se circunscreviam em um universo mais restrito. Não só noções como mendigo e indigente começam a ser abandonadas na ordem dos discursos públicos, como uma classificação mais sociológica pautada pelo signo diacrítico rua começa a surgir; mas também as categorias de povo e sofredores, urdidas no interior do trabalho religioso com estas pessoas, são deslocadas por uma noção aparentemente mais neutra e politicamente mais operacionalizavel, a de população. Apesar de o livro ressaltar que a categoria população de rua permanece ainda como um termo genérico, com sua divulgação, todos aqueles personagens até então anônimos, inomináveis e invisíveis publicamente, adquirem um lugar um pouco mais estável num sistema cambiante de classificações, transmutando-se em sujeitos saturados de qualidades muito específicas. Por ser enunciada através de uma linguagem autorizada (Bourdieu, 1996) e qualificar mais precisamente a questão de maneira a torná-la compreensível e reconhecível para um público mais amplo, esta obra constitui-se como um marco fundamental, uma ruptura na historia social deste dispositivo de ligações, ao nomear o 
que até então era inominável e produzir poderosos efeitos de visibilidade sobre aqueles que permaneciam às sombras.

E a alteração do poder municipal, em 1993, produz novos efeitos nas relações estabelecidas neste campo de forças, no qual a trajetória de Mabel e de outros atores situamse. O Fórum Coordenador dos Trabalhos, que até então era articulado no interior da Secretaria do Bem-Estar Social, sofre um deslocamento de posição e de nomeação. Apesar das reuniões entre as organizações continuarem a acontecer, estas não mais se passam no interior da prefeitura e nem recebem seu apoio. Também seu nome é alterado para Fórum das Organizações que Trabalham com a População de Rua, nome este que permanece até os dias de hoje. Contudo, mesmo não tendo apoio da prefeitura, este Fórum conta com a presença de algumas autoridades públicas, tais como a então vereadora Aldaíza Sposati. E no seio das relações travadas neste Fórum é que se esboça o primeiro projeto de Lei de Atenção à População de Rua. Tudo isto no meio de um intenso embate político para se manter aquela ordem de relações alcançadas na gestão anterior de Erundina:

E a gente lutando para os projetos continuarem. A (gestão) Erundina foi muito boa, mas não fechou nenhuma lei. Não tinha lei. Todos os projetos não tinham um amparo legal assim, desde o legislativo. Por que se tivesse amparo legal, poderíamos pedir e se o prefeito (Maluf) quisesse encerrar (os convênios), não daria. (...) E assim, porque as organizações que trabalham com a população de rua, a gente tinha um inimigo comum e fomos fortalecendo, se conhecendo. E como tinha um inimigo comum, a gente não brigava muito entre si. Porque a gente precisava um do outro. Entendeu?

Contudo, ainda que a nova gestão do Prefeito Maluf não tenha alterado radicalmente esta constelação de relações entre instituições e atores, é importante enfatizar que, neste processo, enquanto alguns novos convênios foram abertos, outros também foram fechados, como o explicitado no caso da trajetória de Alderon e do CDCM. E junto com todo este redemoinho de ações políticas para o qual a Pastora Mabel fora tragada, existia também a necessidade dela lidar com os desafios próprios à manutenção e às dificuldades cotidianas de uma Casa de Convivência. Nos primeiros dez meses deste convênio, Mabel desenvolvia suas atividades em outros projetos da AEB e era apenas supervisora da Casa de Convivência, indo periodicamente ao local para observar e intervir em certos procedimentos. Depois deste período toda a equipe original foi demitida, Mabel assume a Casa de Convivência como 
coordenadora e então uma série de alterações internas começam a ocorrer ${ }^{25}$. E neste processo Mabel se envolve cada vez mais com a questão da rua. E até hoje, junto com outros personagens, se faz presente em várias manifestações e discussões públicas sobre o tema. Apresentemos, então, outro importante ator que aos poucos foi se fazendo e participando cada vez mais deste jogo de relações em torno da questão população de rua.

\subsubsection{Padre Júlio ${ }^{26}$}

De todos os personagens aqui apresentados, Padre Júlio Lancellotti é sem dúvida a figura mais pública. Nosso encontro se deu na sede da Comunidade São Martinho de Lima, no bairro da Mooca, onde possui uma Paróquia e também desenvolve atividades com moradores de rua e jovens em situação de risco. Algumas vezes alvejado publicamente como semeador de discórdias e inimigo ferrenho do poder público, e outras vezes visto como o verdadeiro guardião e porta-voz dos anseios e necessidades dos meninos e adultos de rua, Padre Júlio sem dúvida coloca-se como um importante personagem neste meio. E este reconhecimento ampliado é também causa e efeito de suas relações de proximidade e distância com outros poderes urbanos, sejam estes religiosos, executivos, judiciários, legislativos, midiáticos, e até mesmo acadêmicos. Seu carisma manifesta-se justamente como efeito destas relações com espaços sociais ativos e em evidência, e por isso é um importante mediador para com o universo da rua. Ao circular entre autoridades, lugares e instituições paulistanas, este personagem se enreda por relações capazes de levar uma série de valiosos recursos materiais e simbólicos para o universo que se propõe representar. Esta mesma mobilidade e capacidade de transitar por códigos, circuitos e formas de sociabilidade diversas é aquilo que permite que seja conhecido e reconhecido, bem como que o mundo o qual representa e enuncia chegue através de imagens emolduradas e publicamente consagradas às fontes dos recursos e centros ativos da ordem urbana.

Por esta experiência com práticas, discursos e instituições situadas em diferentes posições nas hierarquias sociais, este narrador comporta uma memória muito específica. Seu relato expõe um ponto de vista diferenciado dos processos envolvidos nesta trama de relações

\footnotetext{
${ }^{25}$ As mudanças internas produzidas na Casa de Convivência Porto Seguro estão relatadas e comentadas no terceiro capítulo da dissertação, onde será analisada a dinâmica da rede institucional voltada à população de rua na cidade de São Paulo. Optei por inserir naquele capítulo as alterações do serviço narradas por Mabel, pois o presente capítulo privilegia as relações estabelecidas entre diferentes atores num dado espaço público, sendo que o detalhamento das transformações intra-institucionais, apesar de acompanharem os processos ocorridos neste campo ampliado de relações, pode desviar do foco aqui proposto.

${ }^{26}$ Júlio Lancellotti foi entrevistado em 03/10/2007
} 
e por isso é capaz de descrever trajetórias e movimentos de componentes que até aqui foram evocados apenas pontualmente. Assim, a ampla pluralidade de jogos sociais que este narrador atravessou ao longo de sua trajetória, o permite articular e expressar movimentos operados em conjuntos e em maiores escalas de ação. Assim, seu relato expõe o surgimento da Pastoral da Rua, os deslocamentos da Casa de Oração, o intrincado percurso da regulamentação da Lei de Atenção à População de Rua, bem como o efeito das alterações dos poderes urbanos nestas relações. Os relatos enunciados por Padre Júlio permitem entrever como a construção e instauração de políticas públicas são também resultados de sucessivas ocasiões, acasos e eventos de negociação, e não unicamente resultado de firmes propostas e posições políticas ou partidárias. Ao vivenciar momentos privados e de intimidade com outros personagens públicos e notórios, ocasiões instantâneas e fugazes, mas que explicitam o encontro e confronto de lógicas, interesses e, portanto, mundos sociais distintos, suas lembranças evocam narrativas que jogam luz sobre sombras informes de processos que, por outras perspectivas, seriam insuspeitos.

Natural de São Paulo e de família de origem italiana, Júlio Lancellotti construiu vínculos muito fortes com a região da cidade em que cresceu. Não por acaso até hoje vive, trabalha e atua nos bairros do Belém, do Brás, da Mooca e suas redondezas. Atualmente Padre Júlio, com o título de Vigário do Povo da Rua, é um dos responsáveis, na cidade de São Paulo, pela Pastoral da Rua e pela Pastoral do Menor. A primeira destas atribuições só foi criada em meados da década de noventa, já a segunda foi construída no começo da década de oitenta. A criação das primeiras Pastorais acompanhou o já comentado movimento de reforma da Igreja Católica na América Latina e foi definida na década de setenta. Contudo, restringiam-se a quatro prioridades de ação: Pastoral do Mundo do Trabalho, Pastoral dos Direitos Humanos e Marginalizados, Pastoral da Periferia e Pastoral das Comunidades Eclesiais de Base (Singer; Brant, 1983). Só posteriormente é que foram criadas outras Pastorais pela Arquidiocese de São Paulo. Os títulos e atribuições simbólicas que Padre Júlio possui foram sendo adquiridos temporalmente ao longo de sua trajetória e ao longo das transformações a que o espaço social atravessado foi submetido. Apesar de possuir um destaque considerável na veiculação pública e, assim, na construção simbólica da imagem e questão população de rua, Padre Júlio Lancellotti será tratado da mesma maneira que os outros personagens aqui apresentados. Ou seja, a preocupação não cairá sobre o ator em si e sim sobre as trajetórias e conexões parciais que foram se constituindo em torno da população de rua e que são expostas em sua narrativa. 
Padre Júlio conta que começou a se envolver com o universo da rua no início da década de oitenta, quando então já era consagrado como Padre. E este envolvimento inicia-se através de Nenuca, irmã Oblata da Fraternidade de São Bento, quando então se discutia, nas Pastorais Sociais, a questão da criança e do adolescente. A partir deste encontro com Nenuca, começa a freqüientar as Missões então organizadas pelos integrantes da Comunidade dos Sofredores de Rua.

Nesta mesma década assume a Paróquia da Mooca e sua atenção começa a voltar-se para as questões de migração e para os moradores de rua que viviam no bairro. Desenvolve atividades numa instituição localizada na antiga Hospedaria do Migrante, no bairro do Brás. Junto com alguns outros equipamentos da época, esta instituição era uma das únicas que acolhia pessoas que viviam nas ruas, apesar de estar voltada especificamente para a questão da migração. Hoje, este espaço institucional foi assumido por uma congregação católica de origem italiana e mudou seu nome para Arsenal, tornando-se o único albergue conveniado com o governo do estado de São Paulo e o maior equipamento institucional para população de rua da cidade, com capacidade para comportar mais de mil e duzentas pessoas:

Depois quando eu vim aqui para a Paróquia, que eu comecei a localizar os moradores de rua
que estavam aqui embaixo do viaduto Guadalajara e aífoi com o trabalho junto com eles, que
nós começamos a Comunidade São Martinho, que hoje tem dezesseis anos de fundação e
atende a quinhentas pessoas por dia. Aí foi o início do atendimento municipalizado da
população de rua no governo da Luíza Erundina. Porque até então, quem atendia a
população de rua era o governo do estado, e eu já tinha trabalhado lá no Departamento dos
Imigrantes, lá onde hoje é o Museu da Imigração. Porque ali durante muito tempo trabalhou
com migrantes, mas depois a população de rua acabava indo para lá onde é o Arsenal hoje.
Ali era o DAIS, que era o Departamento de Integração Social. E ali era uma coisa tremenda,
era o fim do mundo. E tinha também o CETREN.

Apesar de participar das Missões estimuladas pela OAF desde o começo da década de oitenta, é só no final desta década que Padre Júlio começa a trabalhar diretamente e adentra mais na questão da população adulta de rua. Não por acaso, a fundação da Comunidade São Martinho de Lima, que trabalha até hoje com esta população e cujo nome jurídico da ONG é Nossa Senhora do Bom Parto, data justamente de 1989, quando a gestão municipal de Erundina começa então a implementar serviços de atendimento a este contingente. E esta ONG é a primeira a fazer convênio com a prefeitura, iniciando um processo de parcerias entre 
terceiro setor e poder municipal que posteriormente irá desembocar numa complexa rede de serviços e instituições, voltados ao tratamento e à proteção social desta população. E Padre Júlio conta um pouco deste processo, bem como as dificuldades que teve no bairro ao começar a trabalhar com este público-alvo não tão bem visto pela vizinhança:

Depois no governo da Luíza é que nós começamos a discutir muito essas questões a nível municipal, aí que surgiu a Comunidade São Martinho de Lima do Povo da Rua, aqui na Mooca. Surgiu a casa Porto Seguro, com a AEB. E aí surgiu o albergue da Pedroso, na Igreja Metodista, ali na 23 de Maio, no Viaduto Pedroso. E foi quando também surgiu a Rede Rua (CDCM), com o apoio do município. Foi o início do trabalho municipal, tanto que a secretaria não queria de jeito nenhum esse trabalho. Foi o pulso firme da Luíza Erundina mesmo que fez com que essa coisa acontecesse.

Ela veio na inauguração do São Martinho, quando nós aqui sofremos ameaças terríveis. A Luiza teve um gesto bonito. No inverno não tinha operação inverno. Tinha a sopa da Ivete, começou a ter essas coisas, mas o pessoal morria na rua de frio. Aí nós começamos a abrir os abrigos de emergência e aí abrimos um aqui dentro do Centro Esportivo, na Mooca. E a Mooca sabe como é, é malufista, discriminadora, preconceituosa. Então houve muita ameaça. Realmente passei uma fase complicada mesmo, até um carro subiu em cima da calçada para me pegar. Eaí a Luíza veio fazer uma visita aqui na região e veio caminhando até chegar ao São Martinho, manifestando apoio público. Veio na noite ver o povo dormindo lá no centro esportivo (...) E ela falou: "Como isso pode causar tanta coisa?" Porque de manhã a gente limpava o centro esportivo e saia (de lá), mas causou um impacto muito grande no bairro. A população de rua acho que mexe muito com o imaginário das pessoas (...) Eles são vistos como que se fossem eles que sujam a cidade, são todas essas coisas que incomodam demais, a visão da população de rua incomoda demais, tanto que aqui na Mooca hoje é uma das áreas com mais moradores de rua e ficou a fama que a Mooca era ótima, foi depois que eu vim para cá que 'empesteou' a Mooca.

"Empesteando" ou não a Mooca com moradores de rua, este tipo de dificuldade com a vizinhança foi algo que outros serviços de atendimento também passaram quando começaram a trabalhar com esta população. Este evento aqui contado, no qual a então prefeita foi até o abrigo de inverno apoiar as atividades ali desenvolvidas, foi também narrado publicamente por Padre Júlio no Primeiro Seminário Nacional sobre População de Rua. Este seminário foi realizado, também na gestão Erundina, pela então secretária do Bem-Estar Social com a participação de todas as entidades sociais de São Paulo que trabalhavam com a população de 
rua na época. $\mathrm{O}$ encontro possibilitou dar mais visibilidade ainda à questão, pois além de contar com a presença de professores universitários e autoridades públicas, ampliou a escala de interlocução da questão, já que travou diálogo com experiências semelhantes em outras localidades do país ${ }^{27}$.

Contudo, na passagem para a gestão Maluf, as relações entre as entidades sociais e a prefeitura encontraram-se numa situação de tensão e instabilidade. Algumas organizações tiveram seu convênio encerrado e outras tiveram seus recursos reduzidos. E como conquistas políticas de lutas passadas não são tão facilmente abandonadas, esta mudança causou toda uma mobilização entre as organizações que trabalhavam com a população de rua. Padre Júlio narra dois eventos que se passaram neste período e que demonstram um pouco a atmosfera política da época, bem como a maneira na qual o próprio narrador posicionava-se nestes jogos de relações de força e suas alianças estratégicas:

Olha, no tempo do Maluf foi dramático. Porque aí ficou tudo paralisado. Aqui (Comunidade São Martinho) continuou, mas com muita dificuldade, porque o que aconteceu? Na administração do Maluf, as entidades fizeram protesto e fizeram o enterro (encenado) do Maluf. E levaram lá o caixão e fizeram o enterro. E o nome da nossa entidade, Nossa Senhora do Bom Parto, apareceu na fotografia do enterro. Então o Maluf tomou a decisão de que ia asfixiar a nossa entidade, ela ficou oito meses sem receber, eles queriam que quebrasse mesmo. Aí nós conseguimos o apoio do Chico Pinheiro (jornalista da Globo). E o Chico Pinheiro pôs (o caso) na Globo a semana inteira e no fim (de semana) pôs a irmã Judith, que é assistente social (da Comunidade), num debate com o secretário da Assistência Social. E foi uma lavada realmente, eles podiam imaginar tudo, menos que nós íamos ter aliados na Globo. E aí (a verba) voltou e não tiveram jeito, mas aí aconteceu uma coisa também, que o Maluf não abriu os abrigos de frio. E morreram dezoito pessoas na rua, de frio (...)

E aí, o quê que aconteceu? Nós fizemos um acampamento de emergência embaixo do Viaduto do Glicério, e chamamos Dom Paulo. Aí Dom Paulo ligou para o Maluf e falou: "Eu vou dormir com o Povo da Rua debaixo do viaduto se você não abrir o abrigo de frio, e Deus está mandando você abrir porque senão...bebebe”. Falou um montão lá para o Maluf, deu uma confusão, porque (estava) toda a imprensa junto, Dom Paulo debaixo do viaduto com o Povo da Rua. O secretário da Assistência Social me chamou correndo lá no gabinete dele e disse: "Você quase me derrubou". E aí mandou abrir de emergência todos os abrigos imediatamente, mas aí o povo não queria ir para os abrigos da prefeitura, queria ficar no nosso, porque no nosso tinha música, fogueira, sopa. Era a maior festa, o nosso, né? Era

\footnotetext{
${ }^{27}$ As apresentações deste seminário foram publicadas três anos depois, num livro chamado População de rua: Brasil e Canadá, organizado por Cleisa Moreno Maffei Rosa (1995).
} 
muito mais informal, mas aí abriram os abrigos. Então tem uma história de muita pressão na construção dessa questão da política pública.

É na passagem da década de oitenta para noventa que a imagem de Padre Júlio vai se projetando no espaço público e se firmando mais consistentemente, enquanto um agente ligado politicamente aos interesses da população de rua. Coloca-se na frente dos embates que se sucederam após a gestão Erundina, articulando e mobilizando entidades que trabalham com a questão. E na década de noventa, o número de entidades conveniadas vai gradativamente aumentando, bem como são feitas novas contagens sobre o número de pessoas dormindo nas ruas e em albergues, que demonstram o crescimento desta população. Também neste período aumentam o número de notícias em periódicos sobre o tema, multiplicando ainda mais a coleção de classificações referentes à problemática e, ao mesmo tempo, estabilizando cada vez mais a nomeação população de rua como uma categoria genérica capaz de incorporar toda uma heterogeneidade de situações e trajetórias pessoais ligadas, de uma maneira ou outra, ao universo da rua (Rosa, 2005). Simultaneamente à amplificação pública da problemática na cidade de São Paulo, as atuações políticas desempenhadas por Padre Júlio em torno da população de rua vão tornando-se cada vez mais reconhecidas. E o auge deste reconhecimento talvez seja em 1997, quando assume o Vicariato Episcopal do Povo da Rua, este ramo da Arquidiocese Metropolitana especialmente voltado para esta questão. E esta assunção está enredada por questões outras e ele mesmo nos relata:

Na época eu estava na Pastoral do Menor. Nós trabalhávamos também com pessoal da rua embora não se chamasse Pastoral de Rua. E no governo do Fleury (1991-1994), nós tivemos muitos problemas com o governo (...) Eles fizeram uma reunião no Palácio dos Bandeirantes, com alguns bispos, com cinco, seis bispos do estado de São Paulo. E aí eles se queixaram de alguns padres, dizendo que alguns padres atrapalhavam o trabalho deles, e é claro que apareceu o meu nome lá no meio.

Como resultado desta pressão política sobre o bispado paulistano, alguns padres são deslocados de seus cargos de atuação. Neste processo, Padre Júlio é destituído de seu cargo na Pastoral do Menor, só que não é avisado e fica sabendo disso num anúncio público de uma assembléia da Pastoral. Após algumas trocas de cartas com Dom Paulo, vai até sua casa: 
E aí nós fomos até lá e pedi para falar sozinho com Dom Paulo. Ele estava na cama, tinha quebrado o pé, aí eu queria me confessar, tudo. Conversando, ele falou para mim: "Eu queria que você aceitasse ser o Vigário Episcopal do Povo da Rua". Eu falei: "Eu vou pensar, Dom Paulo, eu não posso responder isso agora". Isso para um alemão e um Arcebispo como ele, é complicado. Você imagina, ele dizer uma coisa e você falar que vai pensar e vai dar a resposta depois. E aí eu fui consultar a Regina, a Ivete, o Padre Arlindo. Fui perguntar. Por que eu vou decidir uma coisa sozinho? Aí todos acharam que sim. Aí eu liguei para a casa dele, mas ele não estava, deixei recado dizendo: "Dom Paulo, aquela proposta que me fez, a resposta é sim”.

Apesar de ter aceitado a proposta, foi só na noite de Natal, "numa manifestação com o Povo da Rua até a Catedral", que o fato foi anunciado publicamente. Quando, durante a missa, Dom Paulo disse: “A partir de hoje está criada na Arquidiocese de São Paulo o Vicariato Episcopal do Povo da Rua, e o responsável é o Monsenhor Júlio Lancellotti”.

Apesar de ter sido criada em 1997, a Pastoral da Rua só vai ultrapassar o território metropolitano e ter alcances nacionais na década seguinte. Contudo, o assinalável desta passagem aqui narrada por Padre Júlio é que no momento em que é efetuada a proposta de se criar uma Pastoral da Rua e dele a assumir, os atores que tinham mais história e experiência com o tema são "consultados". Assim, antes de assumir uma nova posição neste campo de relações, Padre Júlio ouve o parecer de atores já reconhecidos e conhecedores deste meio. E é neste processo, referindo-se diretamente aos portadores do saber deste campo e recebendo a designação pública do Cardeal Arcebispo Dom Paulo, que Padre Júlio se transforma em um dos porta-vozes autorizados do mundo da rua ao assumir o título e a posição de Vigário do Povo da Rua. E é também neste mesmo ano de criação da Pastoral da Rua que se consegue finalmente um espaço próprio para a Casa de Oração, espaço onde a OAF, desde o final da década de setenta, desenvolvia atividades religiosas e de formação de grupo junto com esta população:

A Casa de Oração, ela tem uma longa história, porque surgiu de uma intuição da Nenuca. A primeira Casa de Oração foi atrás do Mosteiro de São Bento, naquela casinha da Florêncio de Abreu, que aí os irmãos beneditinos depois não quiseram mais, ficaram com medo, sei lá e botaram para a rua. Eu já freqüentava aquela Casa de Oração, tanto que aquilo lá está fechado e parado do mesmo jeito até hoje. Aí ficamos na rua. Depois foi para trás da igreja São Francisco, num salão dos franciscanos, que por sua vez também mandaram embora. E ficamos na rua de novo. Aí quando Dom Paulo ganhou o prêmio "Mil anos da Paz" dos 
budistas, um prêmio que comportava um tanto de dinheiro, Dom Paulo recebeu e disse que ia dedicar à população de rua. Aí ele me chamou e disse: "O quê que vocês querem fazer? Um albergue, um centro?". Aí nos juntamos com a Regina, a Ivete, o Padre Arlindo, todo esse grupo. E o quê que vamos fazer? Vamos fazer outra vez a Casa de Oração, só que dessa vez ela vai ser nossa, não vai ser dos beneditinos nem dos franciscanos, vai ser da arquidiocese, $e$ aí nós construímos, lá na Luz, a Casa de Oração do Povo da Rua, que é a que tem hoje.

Estes processos aqui narrados tornam possível apreciar como os deslocamentos ocorridos no universo da rua e suas mediações também acompanham e se articulam com os eventos e transformações ocorridos na Igreja Católica. Dom Paulo Evaristo, que fora um importante "aliado do Povo da Rua" em todo percurso temporal aqui exposto, no final da década de noventa afasta-se de seu cargo. E sua presença é considerada tão importante neste campo, que sua saída é motivo para a publicação de um livro chamado: Elogio a Dom Paulo. Este livro é composto de vários depoimentos de agradecimento, feitos por pessoas vinculadas ao universo da rua, de filiação católica ou não. Estes depoimentos relatam situações de apoio e expressam a ajuda que o Cardeal forneceu ao trabalho com o Povo da Rua durante seu arcebispado. Contudo, com a entrada de um novo Cardeal, as coisas poderiam mudar. Por isso a definição de sua posição neste jogo de alianças e tensões políticas era algo de grande importância para as instituições e os agentes conectados ao universo da rua. Assim, na alteração do poder eclesiástico da cidade, na passagem para a nomeação do novo Cardeal Arcebispo Dom Cláudio Hummes, estes atores e, assim, o universo do qual são representantes, se fizeram presentes:

E quando Dom Cláudio foi nomeado Arcebispo, era próximo da Conferência Nacional dos Bispos lá em Indaiatuba e o Povo da Rua foi convidado. A Comunidade dos Sofredores de Rua, a Ivete e a Regina, foi todo mundo convidado a ir até lá cantar o ofício divino à noite e eu fui junto. E nós íamos dentro da estrutura fazer o Elogio a Dom Paulo e então eu falei para as irmãs: "Vamos levar um presente para Dom Cláudio, porque ele foi nomeado Arcebispo. A gente leva alguma coisa para ele” (...) Aí Dom Cláudio estava lá e nós fizemos a oração, fizemos o Elogio a Dom Paulo. E estava cheio de bispos naquela ocasião. Então dissemos: "Queremos agora entregar um presente para Dom Cláudio, que acaba de ser nomeado arcebispo de São Paulo. É uma cruz (feita) de madeira que foi encontrada na rua, feita pelo povo da rua e que é o nosso sinal de acolhimento, de que nós o acolhemos como irmão, como pastor e não queremos dizer que São Paulo será uma cruz, mas será nosso símbolo de união" (...) Aí realmente selou uma amizade de Dom Cláudio com o trabalho com a população de rua 
muito grande, tanto que ele tem sido de um apoio muito grande. E o que entrou bem na cabeça de Dom Cláudio, que nós passamos para ele é a questão da política pública. Isso gravou na cabeça de Dom Cláudio. De que não é a igreja que tem que resolver o problema social, de que nós temos as entidades, temos os convênios, temos experiência, mas que isso não é filantropia, isso é política pública complementar, e que nós temos que exigir ação do governo, seja municipal, estadual ou federal.

Era importante estabelecer um compromisso público com esta nova autoridade católica e, assim, reafirmar a posição do arcebispado metropolitano nesta constelação de relações de força. Por isso a presença destes atores no momento de nomeação do novo cardeal era tão fundamental, pois selou um laço que possibilitará um importante apoio em futuras articulações políticas com o poder público.

Desde o final da gestão Erundina, permaneciam freqüentes os encontros do Fórum das Organizações que Trabalham com a População de Rua. E no seio destes encontros - entre trabalhadores sociais, agentes religiosos, políticos e moradores de rua -, a idéia da formulação de uma Lei Pública para esta população ia adquirindo maior consistência e, ao mesmo tempo, tendo de atravessar sinuosos caminhos para sua aprovação e efetivação. A proposta era construir uma lei que garantisse a defesa dos direitos mínimos a esta população, bem como regulasse e tornasse obrigatória a ação da prefeitura neste campo, com um orçamento definido, objetivos específicos e formas de trabalho e intervenção já apontadas. Entretanto, até sua regulamentação, muita coisa aconteceu e Padre Júlio relata um pouco da intrincada trajetória da lei que atravessou este campo irregular, com alterações do poder público municipal, bem como alterações do próprio poder eclesiástico:

Porque tem todo esse caminho, dos dias de luta, da formulação da lei, da aprovação da lei. A aprovação da lei também tem os caminhos intrincados. A lei foi elaborada com a participação das entidades da população de rua. Bom, o projeto da lei foi aprovado na Câmara (Municipal), num acordo. O Maluf era o prefeito na época e vetou a lei. Mas num arranjo da Câmara, os vereadores resolveram derrubar os vetos (...) Aí fomos todos para Câmara, manifestação, o Povo da Rua e tal. Claro que ele (presidente da Câmara) promulgou a lei. Mas quando ele promulgou a lei, já era passagem para o governo Pitta, que argüiu a lei por "inconstitucionalidade por vício de iniciativa”. A Câmara não poderia propor uma lei que gere gastos para o Executivo, essa figura se chama vício de iniciativa. 
Contudo logo após este episódio, inicia-se toda uma série de acusações de corrupção contra o prefeito Pitta e, neste processo, começa-se a anunciar a possibilidade de seu impeachment. E foi em meio a estas relações que, após uma sucessiva cadeia de acasos e malentendidos, Padre Julio e Dom Paulo foram expostos publicamente, em jornais como a Folha de São Paulo, como contrários ao processo de impeachment do então prefeito. Entretanto, é justamente este mal-entendido que permite um enlace e um compromisso do perseguido prefeito com as relações que envolviam o universo da rua:

E a Folha de São Paulo editou em duas páginas, em preto e branco quem era contra e a favor do impeachment. Eu não sei por que a Folha fez aquilo e me puseram contra. Colocaram que eu era contra o impeachment. E o Pitta me telefonou, para agradecer. Ele estava muito agradecido com Dom Paulo, muito agradecido comigo. Aí o Pitta foi para uma reunião na casa de Dom Paulo, que me chamou para o encontro (...) Eu conversei com o Pitta sobre a lei e aquela coisa toda. E neste ínterim Dom Paulo já estava saindo de cena também e já tinha entrado o Dom Cláudio. Mas ainda o Pitta estava com toda aquela história do Dom Paulo e de que eu tinha defendido ele na Folha (...).

No mês de maio de 1998, é efetuado o oitavo Dia de Luta da População de Rua, do qual participam da organização o recém criado Vicariato do Povo da Rua, a Coopamare, a OAF, a Rede Rua, a AEB, o Centro de Direitos Humanos Gaspar Garcia, o Fórum da População de Rua, além de vários usuários de equipamentos institucionais e políticos, tal como a então vereadora Aldaíza Sposati. E é neste evento que a prefeitura recebe pela primeira vez, após a gestão Erundina, as entidades não governamentais e a população de rua. Como resultado deste encontro com o prefeito, além dele "desistir" da ação de inconstitucionalidade da Lei e abrir a primeira frente de trabalho para esta população, são criadas novas vagas em albergues ampliando, deste modo, a rede de atendimento a esta população:

Ele desistiu da ação de inconstitucionalidade, mas precisava a justiça homologar e aí a justiça homologou, só que até a justiça homologar, demorou e o Pitta não regulamentou a lei. Só que aí já estava na campanha eleitoral (para prefeitura) e nós convidamos a Luíza Erundina e a Marta Suplicy - não convidamos o Maluf porque ele já tinha vetado a lei - para que quem fosse eleito assumisse como primeiro ato, regulamentar a lei. A Marta ganhou e, realmente, o primeiro ato da Marta foi regulamentar a lei. E foi aquele desastrado almoço no pátio do colégio com os moradores de rua que deu uma luta, foi aquela bagunça. 
Perg.: É mesmo? Por que deu bagunça?

Porque ela assumiu o compromisso que iria regulamentar e ia almoçar com o Povo da Rua, só que não podia almoçar com todo mundo. E foi lá no Pátio do Colégio, lá dentro do restaurante. Só que eles anunciaram aos quatro ventos na imprensa: "a prefeita amanhã almoça com o Povo da Rua”. Então você imagina: todo mundo foi lá para almoçar junto com a prefeita, e não foi suficiente, porque o lugar era pequeno, deu a maior confusão (...)

Naquele dia, com o Cardeal presente, Dom Cláudio, ela regulamentou a lei. Agora, isso se você for ver, foi do Maluf à Marta. Foram três administrações até chegar na Marta. No governo dela a lei foi regulamentada e até hoje nós estamos na briga para a lei ser efetivada. Mas é uma história interessante, porque a história não é linear, e nem é só o que aparece, tem todas essas coisas de bastidores.

Assim, só na gestão municipal de Marta Suplicy é que a Lei de Atenção à População de Rua é regulamentada, num evento um tanto conturbado e que se tornou capa de vários jornais da cidade. Contudo, a regulamentação desta lei não implicou num término dos conflitos entre organizações ligadas à população de rua. Implicou sim, numa redefinição dos embates. Permanece a luta para o cumprimento da lei, uma peleja política que se arrasta até os dias de hoje sob várias modalidades. E entre estas os próprios Dias de Luta da População de Rua, dias que também produziram outros efeitos, como nos narra Padre Júlio:

Os dias de luta da população de rua deram alguns efeitos, um deles são hoje os nossos agentes comunitários, que são úteis, hoje nós temos trinta e quatro agentes comunitários de saúde da rua. Que são pessoas que viveram situação de rua e que hoje estão (numa situação) melhor (...) Que foi nos Dias de Luta sobre a saúde que nós conseguimos essa conquista. No governo da Marta, nós conseguimos acho que dez ou doze agentes, mas era muito pouco. Começarmos com um número muito pequeno, aí nós fomos ampliar. Logo que o Serra tomou posse (2005 em diante), teve um secretário da saúde que não falava com ninguém, que era aquele do Einstein, aí ele caiu e entrou a Dra. Cristina Cury. E assim que a Cristina Cury tomou posse, morreu uma pessoa na rua, na porta do PS (pronto socorro) de Santana, e aí ela declarou para imprensa: "Morreu no lugar que devia". E aí a imprensa veio me perguntar: "O senhor acha uma declaração sórdida, ou uma declaração de desprezo"? "É sórdida realmente". Aí saiu isso na imprensa, aí a Doutora Cristina me ligou e disse: "Ah, lhe devo uma satisfação, um pedido de desculpa". Falei: "Para mim não, a senhora deve o pedido de desculpa ao Povo da Rua e a senhora devia conversar com agentes comunitário de saúde da 
rua". Aí ela marcou, e eu fui com os agentes lá, com uns dez, lá no gabinete dela. Eles começaram a falar e ela começou a chorar. Aí eu disse: "Então, desse encontro tem que sair a ampliação dos agentes". E ela ampliou para trinta e quatro, com uma enfermeira, com três enfermeiros, teve uma ampliação robusta, mas que nasceu da crise, nasceu do confronto.

O agente comunitário de saúde da rua atende diretamente as pessoas que se encontram nas ruas da cidade e que dificilmente têm acesso a alguma forma de atendimento médico. Assim, sua função é justamente a de prover uma conexão entre o morador de rua e o atendimento da saúde. Estes agentes possuem trajetórias de rua e esta é uma prerrogativa de sua contratação: conhecer a linguagem e ter experiência com o universo das ruas de São Paulo, até porque existe uma resistência muito grande neste universo a qualquer forma de institucionalização. Assim, eles são apenas mais uma das muitas modalidades de agentes que aos poucos vai aparecendo e dando forma a este dispositivo histórico voltado à população de rua. E na proliferação e suscitação destes múltiplos agenciamentos, entre fóruns, organizações não governamentais, manifestações de rua, agentes pastorais e da saúde, outros atores também vão se constituindo. Voltemos-nos, então, para uma outra trajetória, esta agora que permite elucidar os percursos que levaram ao nascimento do Movimento Nacional da População de Rua.

\subsubsection{Anderson $^{28}$}

$\mathrm{Na}$ entrada deste milênio, muitas coisas no universo da rua se transformaram. E não foram unicamente decorrentes da abundância de elementos que começaram a envolver a questão - tais como a nova Lei de Atenção à População de Rua, o impressionante crescimento numérico deste contingente registrado nos últimos quinze anos, a propagação de notícias veiculadas em periódicos sobre o tema e a considerável ampliação do aparato institucional direcionado a esta população. O que deve ser assinalado é que o aumento em quantidade de números, discursos, instituições e agentes voltados a esta questão, também alterou significativamente sua qualidade. Ainda que todos estes agenciamentos apóiem-se localmente sobre procedimentos de interdição e regulação, eles operam através de uma rede de mecanismos entrecruzados que passa a legitimar e suscitar a emergência da população de rua como um sujeito coletivo de direitos. A conformação de um intrincado dispositivo de poder que interroga, provoca, atravessa e organiza tal problemática, dotando-a de maior

\footnotetext{
${ }^{28}$ Anderson Lopes foi entrevista em 14/3/2006.
} 
inteligibilidade, foi aquilo que estimulou o surgimento de um discurso "de reação", no qual a população de rua pôs-se a falar por si mesma, a reivindicar sua legitimidade e sua experiência própria através do vocabulário e do léxico pela qual fora historicamente objetivada e posicionada. E neste contexto é que surge o Movimento Nacional de Defesa e Luta pelos Direitos da População em Situação de Rua, mais conhecido como MNPR. E é por conta do aparecimento desta nova figura na trama desta história, que será aqui apresentada a trajetória de Anderson, uma das principais lideranças deste movimento social na cidade de São Paulo.

A entrevista se deu em sua casa e na época ele morava na Baixada do Glicério, num pequeno imóvel da OAF, onde outras pessoas ligadas à organização também viviam. Anderson havia se tornado pai recentemente e a sala-cozinha, onde a entrevista se deu, estava com duas pilhas enormes de fraldas para bebês. Estas últimas ele tinha ganhado de amigos e conhecidos, mas principalmente de um "compadre" e uma "comadre". Há pouco tinha batizado sua filha, que teve como madrinha e padrinho, nada mais, nada menos, que a vereadora Soninha do PT e o atual secretário da SMADS (Secretaria Municipal de Assistência e Desenvolvimento Social), Floriano Pesaro, justamente do partido oposto da madrinha, PSDB.

Sabe-se que os movimentos sociais urbanos, ao mesmo tempo em que se colocam em oposição ao Estado, também estabelecem com este relações e interlocuções extremamente multifacetadas. (Cardoso, 1987) Algumas destas relações freqüentemente são consideradas espúrias, pois são vistas como formas de cooptação e manipulação dos movimentos para fins políticos que foram construídos fora dele e não a partir dele. (Durham, 2004). Com Anderson não foi diferente. A escolha de seus "compadres" gerou um enorme rebuliço, não só entre outros participantes do MNPR, mas também entre seus apoiadores, como a OAF e a Pastoral da Rua. Na entrevista que tive com Padre Júlio, ele me contou que Anderson havia pedido para batizar, na Casa de Oração, sua filha recém-nascida. O Padre se recusou e a Casa de Oração também não cedeu o espaço para o batizado, que teve de ocorrer em outro lugar e com outro padre. Além disso, vários de seus companheiros, do MNPR, ficaram temporariamente de "cara fechada" com Anderson e, até mesmo, dificultaram sua participação em certos eventos. As acusações foram várias e centravam fogo na questão de que o movimento, e principalmente suas lideranças, não poderia se vincular umbilicalmente ao "seu inimigo", muito mais tendo em conta que a Secretaria Municipal da Assistência Social é um dos principais e, por enquanto, um dos únicos, espaços municipais de reivindicação deste movimento. A justificativa que Anderson me deu veio no final da entrevista, em tom de desabafo. O motivo de sua atitude referia-se a sua preocupação sobre o futuro da criança. 
Disse também que sua vida privada não interferia nos conflitos de caráter público em que estava envolvido. "Minha vida pública e privada não se misturam, mesmo quando o inimigo é o Floriano", seu compadre ${ }^{29}$. Com o passar do tempo, a discórdia aberta pelo acionamento do compadrio com os "inimigos políticos", foi sendo amortecida e seus companheiros e apoiadores voltaram a estabelecer relações com Anderson.

Contudo, antes deste caso ocorrer, muitas coisas, eventos e acontecimentos se passaram na vida de Anderson. Acontecimentos que foram detalhados numa entrevista que durou mais de três horas. Eu havia comprado algumas baguetes e uma garrafa de guaraná para a conversa, que sabia que ia ser longa. E durante todo diálogo, o bebê, recém-nascido e apadrinhado, no colo de sua mãe, lançava inúmeros sons no quarto ao lado. Sons que ecoavam por toda a casa. Ecos que chagavam a nossa conversa e que foram registrados em meu gravador. Com uma trajetória extremamente diversificada, a narrativa de Anderson enuncia alguns dos componentes que permitiram a formação deste movimento social, mas também possibilita entrever melhor as posições e conexões neste campo de forças, através uma perspectiva diferenciada de alguém que passou pela rua, circulou entre instituições, foi catador e também "pegou o trecho".

Anderson conta que nasceu na cidade de São Paulo em 1975. Filho de migrantes, foi registrado apenas por sua mãe mato-grossense, que logo o abandonou com três meses. É levado para um orfanato na cidade de Juquitiba, onde permanece até seus quinze anos de idade. Sua experiência institucional começa, então, desde pequeno e marca todo o fluxo de sua narrativa. É neste orfanato, um "depósito de crianças", como conta, que Anderson vai começar a desenvolver suas competências na viração dos parcos e disputados recursos lá existentes. Muita criança, pouco espaço e muita briga pela comida que "nunca matava a fome de todo mundo". Lembranças não muito agradáveis de um lugar dependente de doações públicas e caritativas, e onde se aglomeravam mais de seiscentas crianças, de várias idades e de ambos os sexos. E segue nesta rotina institucional até que aos dez anos descobre um parente, irmão de seu pai baiano. A partir de então seu tio passa a visitá-lo esporadicamente, o que se torna um importante evento naquelas condições. Contudo, "ele sempre ia me procurar bêbado, e quando estava sóbrio não me procurava". Apesar da presença do tio e do alcoolismo desde pequeno, a trajetória de Anderson não se enredará pelos caminhos da bebida.

\footnotetext{
${ }^{29}$ Pontuo este fato, não com a intenção de me estender nas controvérsias e desentendimentos internos à articulação deste movimento (e supostamente apresentar aquilo que poderia ser visto como uma fragilidade deste), mas o faço apenas com o intuito de demonstrar quão complexa e delicada é a tessitura de relações e alianças políticas, entre os agentes estatais, os apoiadores deste movimento e suas lideranças. Sendo estas últimas marcadas (todas) por trajetórias pessoais de instabilidade, precariedade e experiências de rua. No próximo capítulo retomo a discussão sobre movimentos sociais a luz do caso estudado.
} 
Em 1990 vai para São Paulo, trabalhar e estudar. O orfanato, que tinha relações com algumas empresas, encaminhava seus órfãos para um "emprego certo", "arrumava escola" e também mantinha repúblicas para os jovens estudantes. Morando numa destas repúblicas, Anderson adquire seu primeiro emprego, é mensageiro da rede de hotel Pathernon. E, carregando bagagens de "artistas e famosos", consegue um bom dinheiro de gorjeta. Até que leva sua primeira "queda", perdendo seu primeiro emprego e sua primeira moradia. Havia uma locadora de vídeo ao lado do hotel, onde Anderson alugava fitas para assistir na república que morava, então o porteiro do hotel pede uma fita de vídeo emprestada para Anderson, só que esta subitamente "desaparece":

Eu emprestei para o cara lá do trabalho e ele não me devolveu a fita, ele vendeu para uma outra pessoa. Ele era malandro e eu não sabia da malandragem dele. E o cara do vídeo ficava ligando para o meu trabalho. E ficava ligando direto. Até que o gerente me chamou e falou: "Não dá para ficar segurando você". Mas eu queria ficar, o orfanato tinha me colocado lá. Bom, foi o maior bafafá. O gerente me demitiu. E o diretor do orfanato me expulsou da república e fui para uma pensão, onde fiquei um mês. Aí fui para rua já com quinze anos. Eaos dezesseis anos, já comecei a rondar a rua aqui na área central.

Apesar desta passagem mostrar claramente uma conexão causal no processo de ida para rua, o próprio Anderson narra que, como na república que vivia passava por muitos problemas de convivência que geravam "climas tensos", algumas noites saía de casa para dormir nas ruas. Contudo, só foi a partir da perda do emprego e da vaga na república que Anderson adentra de vez em alguns dos circuitos existentes do universo da rua: dormindo em praças, circulando em instituições, catando latinhas, procurando "bocas de rango" e eventos no espaço público para assistir:

Andava e andava, para lá e para cá. Até que me levaram para o CETREN. Mas quando eu vi lá a polícia mandando a gente ficar pelado, botando um uniforme, aquela coisa azul e branca para você vestir... O uniforme parecia de cadeia, você tinha que tirar tudo, eles guardavam tudo. Aí falei: "Não vou mesmo". Uma vez lá no CETREN quiseram me botar no ônibus, para me mandar embora para outro estado. Queriam me mandar para o Mato Grosso, por causa de minha mãe. Eu falei: "espera aí, eu não conheço minha mãe, eu não vou para o Mato Grosso”. Outra vez queriam me mandar para o Amazonas. Porque lá no CETREN era assim, jogava dentro do ônibus e mandava embora, não queriam nem saber. Eles não queriam era gente pobre em São Paulo. Aí fui vivendo na rua, fui deixando a vida me levar (...) 
Catava latinha, porque andando pelo Centro a gente via: "Compra-se latinha". Tanto que quando eu vim para a Baixada do Glicério, andando por aqui, os caras disseram: "Olha, ali tem um lugar que o preço (do material) é melhor. Aí comecei a ficar mais esperto no negócio e comecei a catar (...)

Eu também fui para o (albergue) Lígia Jardim, que na época te dava quinze dias (de pernoite) e depois te dava mais trinta dias. Você não ficava sempre nos albergues, não eram de seis meses como é hoje, era apenas de quinze dias. É: "Se vira, meu filho". Quinze dias depois, você ia para o Pedroso (outro albergue), do Pedroso você não tinha para onde ir, ia para rua. Mas depois de um tempo podia voltar para o Lígia Jardim.

Com dezoito anos consegue seu segundo emprego, por indicação de uma conhecida do orfanato, e começa a trabalhar como office-boy num escritório de advocacia. E, enquanto isso, consegue uma pensão para morar. Só que não gosta e nem se dá muito bem com o ambiente, então volta a dormir na rua. E quando o chefe "descobria que estava dormindo na rua mesmo trabalhando - porque eu chegava fedendo umas vezes -, ele vinha e me levava num centro espírita, para tomar passe”. Até que este advogado, do qual ficara amigo, arranja um emprego "melhor" para Anderson, como cozinheiro de um restaurante. Depois de oito meses de "exploração", que "quando pagava, pagava mal", Anderson consegue um novo trabalho num motel de estrada, durante a temporada de verão. No começo de 1995 volta para São Paulo "cheio de dinheiro no bolso", só que aí ocorre mais uma "queda". Como o ônibus tinha quebrado no caminho, chega na rodoviária de madrugada, quando não tinha mais transporte público. Então resolve descer e pegar um táxi até uma pensão no Centro:

E a hora que eu estou descendo da rodoviária, me colam três caras armados e me levam tudo o que eu tinha: dinheiro, tênis novo, tudo novo que eu tinha foi embora. E não tinha mais para onde ir. Rua de novo.

Mais uma vez encontra-se circulando nos albergues, que então se estavam sendo abertos. E neste universo, Anderson envolve-se em várias histórias. No Lígia Jardim recebe a proposta de outro emprego, este agora mais informal ainda. Era um trabalho num parque de diversões da zona sul, um "trabalho forçado", como Anderson fala. Ao ir para lá, se vê "preso" em dívidas com a mercearia local e com os seguranças do parque que andavam armados e não o deixavam sair enquanto não pagasse toda a dívida: "Era trabalho escravo, por isso que eles iam pegar morador de rua lá no Lígia Jardim para trabalhar”. Até que numa noite, ele e um amigo conseguem fugir "na moita" e voltam sem dinheiro e caminhando do 
Grajaú até o centro da cidade. Entre esta e outras histórias narradas por Anderson é que ele encontra um papel, convidando pessoas da rua para passar o dia de Páscoa debaixo do viaduto do Glicério. Nesta época Anderson estava dormindo debaixo do Viaduto da Avenida Rio Branco, na Barra Funda, junto com várias outras pessoas e famílias:

Aí eu peguei minhas latinhas e escondi no buraco lá da Barra Funda e fui para o Glicério. Cheguei lá, estava a Ivete, a Regina, Padre Júlio, estava todo mundo ali. Só que eu não conhecia ninguém. Falaram: "entra, seja bem vindo". Tinha comida, música. Comi, cantei, participei. E pensei: "Agora não saio mais daqui, não". Mas acabou, foi só um dia. Aí estavam dando pão com mortadela, e algumas das pessoas já estavam empapuçadas $e$ pegavam a mortadela e às vezes comiam e jogavam o pão no chão. E eu vi aquela senhora baixinha, catando o pão e pondo dentro de uma sacola, e eu comecei a ajudar ela. Ela falou: "você é novo aqui?". Eu falei de onde era. E ela falou: "eu conheço Juquitiba". Aí começamos a conversar e ela me chamou para participar da Comunidade (dos Sofredores de Rua). (...) E a baixinha era a Ivete.

A partir de então, a trajetória de Anderson passa a se conectar com todo um universo de práticas e discursos que o colocam em ressonância com os demais atores aqui apresentados. Começa a freqüentar o Glicério e a sopa comunitária que toda quarta-feira era feita debaixo do viaduto, e que na época já tinha se transformado bastante. Aquela prática coletiva que inicialmente era composta por apenas um grupo de participantes de número restrito - que juntos catavam o resto de comida nas feiras, levavam madeira para o fogo, limpavam e cortavam o alimento, se serviam e comiam - começa a adquirir outras proporções. A quantidade de freqüentadores tinha aumentado consideravelmente, sendo que estes freqüentadores estavam muito mais interessados em participar da "comunidade" dos que comem do que da "comunidade" dos que fazem a sopa. Aos poucos, aquela atividade "comunitária" debaixo do viaduto tornou-se uma verdadeira "boca de rango" para uma população crescente, que chegava a formar filas de até quatrocentas pessoas com a "cascuda" 30 na mão, esperando a sopa. É nesta atividade que Anderson começa a empregar suas competências de cozinheiro. Pica comida, prepara o fogão e cuida dos caldeirões.

\footnotetext{
${ }^{30}$ Cascuda é mais um dos elementos lexicais que compõem a rica linguagem operada no mundo da rua. Diz respeito ao apoio para o alimento, que pode ser um prato, uma cumbuca, uma tigela, ou um pote. Apesar da cascuda ser um utensílio importante para se ter sempre em mãos ou se levar no "galo" (também outra categoria da rua, referente ao saco ou bolsa que se leva nas costas ou em mãos com os utensílios fundamentais para a sobrevivência), algumas pessoas que circulam por este universo podem utilizar outros suportes para alimentar-se, tais como: as mãos, um balde, um saco plástico, ou até mesmo, eventual e tragicamente, o chão.
} 
Posteriormente, no final da década de noventa, estas atividades debaixo do viaduto do Glicério irão passar por um processo de institucionalização, transformando-se na Associação Minha Rua Minha Casa (AMRMC), mais um serviço de atendimento à população de rua na cidade de São Paulo.

Anderson é então convidado e passa a morar na Comunidade dos Sofredores de Rua, no Glicério mesmo. Ao redor do centro comunitário, algumas casinhas, em precário estado físico, foram ocupadas, reformadas através de mutirão e posteriormente alugadas pela OAF. Mais tarde se tornaram "moradia comunitária", auto-geridas pelos próprios moradores e participantes das relações. Claro que tudo isto atravessado por múltiplas microconflitualidades, que foram se arranjando e se desarranjando no seio dos processos locais.

Em 1996, Irmã Regina convida Anderson para trabalhar na Coopamare, que na época já se localizava no viaduto da João Moura, em Pinheiros. Arranjam uma carroça para ele, contudo o trabalho parece muito difícil. Realmente, "puxar carroça subindo e descendo ladeira é duro". Mas apesar de todas as dificuldades, Anderson conta que este trabalho foi aquele em que conseguiu permanecer por mais tempo, cerca de dois anos. Além de tornar-se um catador cooperado, o que o obrigou a participar dos processos de reflexão conjunta, começa também a fazer parte da diretoria da Coopamare e a aprender muito neste exercício de organização coletiva. E isto ele mesmo reconhece: "até hoje a educação que eu tenho de liderança e tudo mais, foi resultado das reuniões, dos grupos de trabalho e da organização que aprendi ali".

Quando sai da cooperativa, faz um curso de chefe de cozinha num hotel do SENAC em Águas de São Pedro. E após o curso, "pega o trecho”. Aí em diante as histórias são muitas. Vale apontar que neste período viaja muito pelo interior dos estados de São Paulo, Bahia e Minas Gerais, "tudo a pé e de carona". E no trecho faz amigos, tem fortes câimbras nos pés, foge de brigas, dorme em vários albergues, se perde e até mesmo é atropelado por um caminhão que o "pega de raspão" andando pela estrada. Nos vários lugares em que passou, chegou a trabalhar como cozinheiro em bares, restaurantes, instituições e fábricas. Nestas veredas conhece muitas pessoas e tem contato com outras experiências de atendimento com a população de rua em Salvador e Belo Horizonte, sendo que quando esteve na capital mineira conheceu Fortunata e Cristina, duas Oblatas do grupo da OAF que haviam saído de São Paulo na década de oitenta ${ }^{31}$. Anderson também ficou por três anos em Salvador, na Comunidade da

\footnotetext{
${ }^{31}$ É importante enfatizar que estas duas Oblatas desenvolveram e ainda desenvolvem um importante trabalho com a população que vive e pratica a catação nas ruas de Belo Horizonte. Experiência da qual se originou a
} 
Trindade, onde morava e trabalhava como catador. Esta Comunidade atualmente é a principal referência com os moradores de rua na capital baiana, através de um trabalho coordenado por Frei Henrique Peregrino, que ocupou a Igreja da Trindade, então abandonada, e começou a organizar as pessoas que já viviam ali.

O assinalável nestas travessias é que as pessoas, instituições e lugares que Anderson conheceu permitiram que ele trocasse experiências de rua, bem como elaborasse um saber mais amplo sobre a questão da população de rua em outras partes do país. Esta circulação por outros espaços sociais e urbanos foi também aquilo que possibilitou que Anderson fosse mais reconhecido neste meio. E este conhecimento adquirido através de suas viagens e deslocamentos é precisamente aquilo que vai ajudá-lo a colocar-se como liderança da população de rua, quando volta para São Paulo em 2004.

Quando chega à cidade, Anderson volta a participar do Fórum da População de Rua, um espaço de interlocução que fora criado apenas três anos antes, com a finalidade de preparar caravanas para Brasília, onde ocorreria a $1^{\text {a }}$ Marcha Nacional da População de Rua. Esta Marcha, que fora em boa parte organizada por várias entidades não governamentais, contou a com a presença de mais de três mil catadores e moradores de rua, viabilizando também o $1^{\circ}$ Congresso Nacional dos Catadores de Materiais Recicláveis, ocorrido no mesmo período. E neste evento é que foi fundado o Movimento Nacional dos Catadores de Materiais Recicláveis $(\mathrm{MNCR})^{32}$. Assim, mesmo depois de efetuada a Marcha em 2001, este Fórum continuou a se encontrar na Casa de Oração. Só que Anderson conta que o Fórum era muito "inibido", pois com a presença massiva de técnicos, "a população de rua não participava muito". Então conversando com uma das agentes coordenadoras do Fórum, disse: "nós da

segunda organização a funcionar como uma cooperativa de catadores de materiais recicláveis no país, a Asmare - Associação dos catadores de Papel, Papelão e Materiais Reaproveitáveis. Esta associação foi criada no começo da década de noventa e é parcialmente tributária das experiências da Comunidade dos Sofredores de Rua, da qual ambas Oblatas integraram. Não por acaso, ela participaram da fundação do INSEA - Instituto Nenuca de Desenvolvimento Sustentável, cujo nome remete à principal condutora das Oblatas em São Paulo. A experiência de Belo Horizonte, bem como de São Paulo, constituíram-se, assim, em importantes referências para o nascimento do Movimento Nacional de Catadores de Materiais Recicláveis, mas também para o posterior nascimento do Movimento Nacional de defesa e Luta pelos Direitos da População em Situação de Rua. Para maiores detalhes sobre a experiência de Belo Horizonte ver o formidável trabalho de Maria Vany de Oliveira (2005) que reconstrói a trajetória dos catadores de papel nesta cidade.

${ }^{32}$ No final do Congresso, foi entregue uma pauta de reivindicações ao governo federal com propostas relacionadas ao reconhecimento da profissão de catador de materiais reaproveitáveis, garantia de participação das cooperativas e associações nos programas municipais de coleta seletiva e criação de linhas de financiamento para as mesmas. Após o Congresso, algumas conquistas foram alcançadas: em 2002, a CBO (Classificação Brasileira de Ocupações) do Ministério de Trabalho reconheceu a ocupação do catador e em 2003 o Ministério do Meio Ambiente promoveu um acordo de R \$4 milhões para projetos de capacitação dos catadores de materiais recicláveis em cooperativas. Uma grande conquista do MNCR foi em fins de 2004, quando o Ministério do Desenvolvimento Social e Combate à Fome efetivou um convênio federal de articulação e capacitação para os catadores organizados de todo país. 
população de rua estamos pedindo para vocês das organizações se afastarem um pouco do Fórum”. E perguntei para ele o porquê deste pedido:

É para gente ter mais autonomia e para poder fazermos o Fórum do nosso jeito, com a nossa cara e não a deles. E aí nós conseguimos divulgar mais o Fórum, porque ele não era divulgado. Nós íamos nas organizações e fazíamos a divulgação, claro que com apoio e o suporte das organizações. Como elas tinham computador, como elas tinham dinheiro, como elas tinham impressora, a gente não pediu para elas saírem, nós pedimos para elas darem um tempo do Fórum da População de Rua e deixar nós organizarmos (...) O Fórum foi se ampliando com mais outras pessoas da rua, e aí começou uma ganância em cima do Fórum e todo mundo queria ser presidente.

E no meio de toda esta dificuldade de se conseguir alguma autonomia em relação às organizações não governamentais, é que a unidade e finalidade do Fórum começam a ser colocadas em cheque, devido a inúmeros conflitos e desavenças internas. Contudo, é neste fórum que se começa a articular e se "trabalhar em cima da questão da autonomia". Neste mesmo ano, ocorre o Festival Lixo e Cidadania, organizado por várias entidades do chamado terceiro setor, tendo como tema os catadores de materiais recicláveis e a população de rua. E neste evento, do qual Anderson participa junto com outros representantes da população de rua do país, são lançadas as bases do Movimento Nacional de Luta e Defesa dos Direitos da População em Situação de Rua (MNPR). Este primeiro momento de articulação inicial do MNPR ganhou impulso, justamente, com o "massacre da população de rua”, ocorrido no centro de São Paulo em Agosto de $2004^{33}$. Segundo Anderson, este massacre foi o acontecimento que permitiu publicizar mais ainda o tema e trazer a tona o debate sobre a necessidade da organização e "construção de um movimento social voltado aos interesses da população de rua".

No entanto, este movimento se encontra em processo de construção, e continua dependente de apoios de instituições e organizações sociais. Segundo Anderson, "o papel do movimento é cobrar seus direitos, cobrar politicamente a Lei de Atenção da População de Rua", sendo que "a proposta é colocar a população de rua na frente do embate, já que muito daquilo que pensamos, não chega através daqueles que falam por nós", e, continua, "temos de saber distinguir entre filantropia e pilantropia”. Um dos principais desafios do MNPR parece ser conseguir alcançar pelo menos uma certa autonomia em relação às organizações que os apóiam e que são, ao mesmo tempo, tão criticadas por alguns de seus integrantes. $\mathrm{O}$

\footnotetext{
${ }^{33} \mathrm{O}$ “massacre da população de rua” será comentado no próximo capítulo.
} 
Movimento dos Catadores (MNCR) é atualmente o movimento social que possui maior interlocução com o Movimento da População de Rua (MNPR) e no qual este último se espelha.

\subsection{Como se inventa uma questão social}

Ao percorrer este período de trinta anos, foi possível mostrar como a população de rua se construiu como questão social, como problema estatístico e sociológico, campo de problematização em que convergem múltiplos atores e seus ancoramentos institucionais. Para que este fenômeno fosse reconhecido como uma questão social e não mais individual e unicamente circunscrita, foi necessário um intenso trabalho de mediação e tradução, capaz de conectar e vincular a experiência de rua com outros elementos. Visto que a realidade de um objeto depende da extensão e solidez da rede mais ampla de objetos no qual está inscrito, nota-se que os atores aqui apresentados foram importantes mediadores no trabalho coletivo de confecção desta rede, capaz de suportar e gerar a população de rua enquanto uma realidade. Eles articularam a experiência de rua através de conexões mais ou menos estáveis, conhecimentos práticos e palavras para qualificá-la. Estes atores foram e são portadores de discursos que, em momentos diferentes, falam sobre a população de rua, para ela, por ela e em nome dela. Nos conflitos que engendraram, estes personagens estabeleceram vínculos discursivos entre a experiência de rua, a pobreza, o desemprego, a falta de moradia e outros temas sociais, dando sustentação legítima para esta problemática. E assim, possibilitaram o reconhecimento desta experiência, dando forma a ela e politizando-a, lançando-a na cena pública a partir de imagens emolduradas, e, tornando-a, assim, uma questão social.

A constituição da população de rua como questão social é resultado de feixes plurais de motivações, atores, instituições e eventos que historicamente foram se encadeando irregularmente, de maneira imprevisível, não linear ou determinada. Contudo, foi o jogo destes atores (e muitos outros), que permitiu a constituição de uma linguagem própria capaz de nomear e lidar com este universo de relações. As trajetórias e os deslocamentos que narraram e viveram, teceram a rede de inteligibilidade que tornou visível e dizível esta população de rua. Antes, a experiência nas ruas, elemento miúdo, menor e localizado (ainda que vibrante e agitado em sua incrível singularidade), não era um problema matizado e articulado no interior de um campo de discursos e práticas capaz de dotá-lo de uma forma mais consistente e acessível à esfera pública. Foram estabelecidos critérios de nomeação, codificação e categorização, ao mesmo tempo religiosos, institucionais, estatísticos e 
jurídicos, montando uma grade de conexões em torno de um foco de problematização e a partir da qual a população de rua ganhou objetividade como tal. Numa concepção puramente pragmática, é razoável afirmar que antes desta gramática de relações ser tecida, não havia população de rua. Não que não existissem pessoas nas ruas, mas sim que era impossível nomeá-las, observá-las e entendê-las como tais. As pessoas que viviam nas ruas, com o passar dos anos começaram a adquirir imagens mais sólidas, e a ganhar números, rótulos e classificações capazes de situá-las na ordem do discurso.

Privilegiei a narrativa de atores que possuem pelo menos quinze anos de experiência neste campo de forças. Esta extensão temporal mínima permitiu a evocação de lembranças capazes de mostrar uma história não linear, na qual estes foram apanhados ao longo de suas trajetórias. Observa-se que os atores que foram escolhidos representam uma geração mais antiga de personagens engajados nesta rede de relações. Com a ampliação histórica desta rede, muitos outros atores, instituições, organizações governamentais e não governamentais passaram a gravitar em torno da questão. No entanto, os atores escolhidos assim o foram, pois suas narrativas, além de exporem um percurso temporal mais longo, permitiram articular um conjunto de enunciados e pressupostos de ação que organizaram e organizam, ainda que sob fortes alterações, estas relações.

Nas narrativas aqui apresentadas, foi dada muito mais importância aos períodos anteriores do que propriamente às práticas e aos contextos mais recentes, isto por dois motivos interligados. Um é que os próprios relatos descreveram mais detalhadamente e deram maior significação aos momentos passados do que os atuais. Ao aproximarem-se do tempo presente, quando os participantes do jogo aumentaram em número e interdependências, a articulação entre os elementos discursivos se afrouxava, tornando-os mais dispersos no interior da estrutura narrativa. Esta dispersão na elaboração do discurso provavelmente também ocorrera pois, como supunham que seu interlocutor estava por dentro dos fatos mais contemporâneos, os narradores não se preocuparam muito em explicar as complexidades envolvidas com a situação atual. Nota-se que, neste caso, a proximidade do pesquisador com o campo estudado inibiu a evocação e elaboração de experiências que poderiam adquirir certa importância. Outro motivo pelas quais as narrativas aqui apresentadas não permitiram enunciar muitos elementos mais contemporâneos foi que deliberadamente optei por não me esforçar em preencher tais lacunas discursivas no corpo do texto ou em detalhar a atual situação desta configuração de forças que, sem dúvida, historicamente foi se tornando mais densa. Como os próximos capítulos dedicam-se a uma etnografia de processos mais 
contemporâneos, preferi apresentar, nesses capítulos, certos componentes da configuração atual.

Apesar de possuírem trajetórias interconectadas, é importante atentar para o fato de que hoje estes personagens se encontram em posições distintas nesta rede de interdependências. Não querendo embotar a especificidade e singularidade dos diversos destinos pessoais, é importante comentar que todos permanecem ligados, alguns mais que outros, ao universo cristão e do terceiro setor. Três destes personagens, Irmã Fortuna, Irmã Regina e Padre Júlio, possuem um estatuto próprio no interior do universo católico e continuam trabalhando em ONGs. Alderon, apesar de ter abandonado o seminário, permanece ainda próximo ao universo católico através da Associação Rede Rua, da qual, junto com Padre Arlindo, ainda é um dos principais responsáveis. Luiz Kohara continua atuando junto ao Centro Gaspar Garcia de Direitos Humanos, onde, junto com outras pessoas ligadas à Igreja Católica, desempenha um importante papel na articulação de diferentes categorias oriundas das classes populares, em especial os movimentos de luta por moradia da região central. Pastora Mabel foi a única personagem filiada ao protestantismo que aqui foi apresentada e permanece trabalhando na AEB. Em verdade, as entidades que trabalham com a população de rua são em sua grande parte católicas, sendo que a presença da Pastora Mabel entre os atores aqui apresentados reflete também a baixa presença dos protestantes neste campo. Outros dois personagens apresentados, Carlinhos e Anderson, apesar de tornarem-se lideranças, tiveram suas trajetórias diretamente conectadas com organizações ligadas à igreja como OAF e a Pastoral do povo da Rua.

As narrativas evocadas foram todas efetuadas a posteriori, ou seja, foram elaboradas a partir do momento atual, com necessidades, intenções e preocupações também atuais e contemporâneas. Assim, tais memórias foram mobilizadas a partir de referenciais presentes no instante interlocutório, que inevitavelmente rearticularam e resignificaram formas e experiências passadas. No entanto, é possível afirmar que todos os relatos apresentados, alguns mais e outros menos, formularam verdadeiras narrativas de conversão. Pois, ao narrar trajetórias de inserção num campo semântico próprio, estes relatos também demonstraram como os significados ventilados neste universo, pouco a pouco, foram incorporados e apropriados, passando a fazer parte e a adquirir importância na vida dos próprios atores que, com o tempo, também passaram a manusear e por em circulação tais sentidos através de referenciais, situações e experiências próprias. Vale dizer, entretanto, esta estas narrativas de conversão não corresponderam propriamente a uma transformação religiosa, corresponderam, sim, à conversão a uma causa social. Ao entrarem em contato e serem embebidos por teias de 
significados que articulam o universo da rua, estes atores foram mobilizados e provocados pelas próprias forças que atuam neste campo, incitando-os para a ação em torno de uma mesma questão que, aos poucos, foi configurando-se naquilo que hoje chamamos de população de rua.

Investi numa certa multiplicidade de perspectivas de maneira a escapar de possíveis narrativas originárias ou fundantes. Contudo, a forte interdependência entre posição dos narradores, narrativas e eventos narrados, colocou-se de tal forma que se tornou muito difícil esquivar-se de certos lugares comuns. Assim, a linguagem na qual todos estes atores se expressam a respeito do universo da rua provém, em grande parte, dos conhecimentos acumulados pelas Oblatas da OAF e que foram sendo apropriados, reempregados e resemantizados no decorrer dos anos. A compreensão da rua como um outro mundo, com regras, especificidades e formas de vida própria, é um tipo de formulação que já estava presente no trabalho desenvolvido pelos integrantes e colaboradores desta organização, e que inicialmente apareceu conectado ao discurso sobre experiência periférica do centro da cidade. Contudo, este mesmo saber, que com o tempo foi se conectando com outros discursos e se articulando mais fortemente através do signo rua, enxergava neste mundo uma ambigüidade que, com certas alterações, permanecerá até os dias de hoje. De um lado, a experiência da rua carregaria em si uma positividade religiosa, já que expressa a vontade de viver e a resistência à morte, e este vitalismo positivo é que tornava possível a crença na capacidade de organização e mobilização na luta pelo reconhecimento de que "somos um povo que quer viver". Por outro lado, a rua já era vista como um lugar de destruição, sofrimento, abandono e dor, e por isso mesmo é que teria que ser alvo de caridade, ajuda e assistência social ${ }^{34}$.

Não há como negar que o conhecimento elaborado junto à Comunidade dos Sofredores de Rua foi a principal matriz discursiva na formação deste campo histórico. E não só pela forma de nomear tais sujeitos, mas também pelos modos de tratá-los. Apesar de saturada de significações religiosas, foi este discurso, também nada homogêneo, que permitiu levar em conta a população de rua, formulando sobre a mesma uma explicação que não fosse unicamente a da moral, mas também pautada por uma intencionalidade política e pedagógica

\footnotetext{
${ }^{34}$ Como vimos no decorrer deste capítulo, o lançamento do livro População de Rua - Quem é, Como Vive, Como é Vista (Vieira; Bezerra; Costa, 1994) é um acontecimento discursivo que permite um desbloqueio epistemológico e político da questão, colocando, pela primeira vez, a experiência das rua como alvo de enunciados estatais, estatísticos e, também, sociológicos. Contudo, a compreensão da rua como um meio periférico, propriamente social, e marcado por uma resistência em relação à ordem urbana, já estava presente no discurso das Oblatas. No próximo capítulo, a ambigüidade sobre o valor do signo rua será retomada a partir de etnografias de manifestações públicas. Vale assinalar, no entanto, que um investimento ambivalente sobre este signo cultural já estava presente nas formulações iniciais desta organização, ambigüidade esta que reaparecerá sob outras roupagens nos dias atuais.
} 
capaz de entendê-la e abordá-la mais eficazmente. Entretanto, se é verdade que a OAF foi a principal matriz na elaboração de um discurso e uma prática em relação à população de rua, coisa que inclusive outras pesquisas igualmente apontam (Barros, 2004, Domingues Jr., 2003), é verdade também que, no desenrolar dos anos, estas "maneiras de dizer e fazer" esta realidade foram fortemente alteradas. Técnicas que foram em muito modificadas ao serem apropriadas pelo Estado, por outros agentes e mediações, e ao tornarem-se modelo de uma política pública focal que foi se ampliando e modificando significativamente no decorrer das últimas décadas ${ }^{35}$.

No entanto, nesta transformação, o que mudou não foram unicamente modalidades de tratamento institucional ou pedagógico no que se refere ao universo da rua, as próprias disposições e interesses nos quais os atores engajaram-se, também, transformaram-se no curso desta história. Uma história que em nada é o resultado dos planos e das intenções destes atores particulares, mas antes constituem o subproduto inesperado do entrelaçamento dos planos e das intenções de uma multidão de agenciamentos díspares. As trajetórias analisadas aqui tão de perto, nada mais são do que a articulação e concretização de diagramas de forças que as perpassam e as ultrapassam. As narrativas atestam a instauração de um novo regime de relações estratégicas entre vários outros elementos, que também são efeitos de engrenagens e encadeamentos múltiplos, que ninguém, por mais poderoso que seja, controla.

O uso dos relatos possibilitou aproximar-nos deste mundo através de uma "visão de dentro", perspectiva que joga com as singularidades numa constelação de interesses e disposições interiores. Estas micro-histórias narradas permitiram observar a especificidade dos atores e os variados modos de integração destes num jogo dinâmico de proximidades e distâncias, dificultando uma redução do complexo ao simples. A montagem do texto e as conexões causais dos acontecimentos acorridos foram articuladas preferencialmente através de narrativas que foram os verdadeiros lastros através do qual foi possível navegar entre diferentes situações, coletivos e lugares na cidade. No que se refere à constituição histórica da questão, privilegiei os difusos pontos de contato entre, de um lado, a cronologia dos atores e suas temporalidades biográficas, e de outro lado, a dinâmica temporal e as transformações do próprio campo de relações analisado. Neste processo tive que adotar uma estratégia textual que apresentasse os atores um por um. Esta abordagem experimental permitiu-me detalhar certos procedimentos e itinerários específicos, mas infelizmente dificultou a compreensão do funcionamento simultâneo desta rede de relações. Seria possível, pois, contar esta história

\footnotetext{
${ }^{35}$ No terceiro capítulo será melhor discutido alguns processos relativos às apropriações e alterações desta matriz discursiva, bem como a entrada de outras técnicas e tecnologias de intervenção e gestão da população de rua.
} 
através de vários outros modelos temporais, contudo, através das cronologias biográficas e coletivas evocadas acredito ter aproveitado mais as construções semânticas imanentes a cada estrutura narrativa, e, deste modo, me aproximado mais da situação concreta nas quais os próprios atores vivenciaram a história ${ }^{36}$.

Acredito que para tecer a trama desta história mais detalhadamente, levando em conta a complexa distribuição das causalidades e o alongamento das cadeias de interdependências, seria preciso atrelar mais profundamente os modelos temporais dos atores e do campo de relações com o próprio movimento da história urbana. Na incapacidade e impossibilidade de reconstituir a teia completa dos discursos, atores e instituições, vale comentar e conectar alguns outros importantes elementos mais "oficiais" da história aqui narrada e que até então foram apenas marginalmente tocados.

E um destes elementos é o próprio Estado, cuja presença nesta constelação de forças alterou radicalmente suas relações ${ }^{37}$. Desde 1989, quando pela primeira vez houve uma preocupação da prefeitura municipal em conhecer melhor este universo vinculado à rua para melhor intervir, até o ano de 2004, a cidade de São Paulo passou por quatro administrações chefiadas por políticos filiados a dois partidos distintos - o PT e o PDS-PPB ${ }^{38}$. É importante atentar para o fato de que esses partidos ocupam espaços opostos no campo político-eleitoral, assim as mudanças do poder municipal foram marcadas por grande descontinuidade política e administrativa. Esta descontinuidade implicou em importantes diferenças de postura a respeito da gestão da cidade, bem como alterou o andamento de certas políticas municipais, inclusive no que se refere à população de rua.

$\mathrm{Na}$ construção de uma nova política municipal para a população de rua, como ocorrida na gestão Erundina (1989-192), se fazia necessário o estabelecimento de uma família de significados comuns não só às organizações e entidades religiosas que trabalhavam com o tema, mas também comum à própria máquina pública. Um imperativo que se colocava, portanto, era o de articular o conhecimento já existente com outros novos, através de uma linguagem específica, mensurável e compatível com a lógica oficiosa e burocrática do Estado.

\footnotetext{
${ }^{36}$ Para uma discussão mais profunda sobre a variação histórica e os possíveis modelos temporais empregados nas formas de articulação entre presente, passado e futuro, ver Lepetit (2001). Aponto apenas que, no próximo capítulo, através de descrições densas de eventos coletivos será possível, ao menos, vislumbrar o movimento conjunto e simultâneo de atores diversos numa dada ocasião.

${ }^{37}$ O Estado é uma instituição prenhe de empecilhos, microconflitualidades e atores internos que um dia deverão ser melhor mapeados em relação à população de rua. $\mathrm{O}$ que fica presente aqui são apenas seus efeitos sobre o campo social analisado, bem como as políticas públicas em relação à população de rua. Uma apresentação mais sistemática sobre estas políticas públicas focais pode ser encontrada em Barros (2006).

${ }^{38}$ O prefeito Celso Pitta, no final de sua gestão, estava filiado ao PTN, mas foi eleito pelo PPB. O PPB, por sua vez, foi criado a partir da fusão do PDS com outros partidos, e recentemente se transformou em PP. Sobre as alterações do poder municipal e a política habitacional, ver Marques e Saraiva (2005).
} 
Ou seja, tais saberes sobre o mundo da rua e suas relações só poderiam ser apreendidos e apropriados legitimamente pelo poder público se inseridos e traduzidos numa ordem discursiva própria à "razão do Estado": a estatística (Foucault, 2004). O estabelecimento deste saber específico à racionalidade estatal foi uma condição para que uma política focal pudesse ser implementada na cidade. Sem informações mais concretas sobre a realidade em que se iria intervir, a criação de convênios e linhas de financiamentos públicos seria inviável. Foi também nesta gestão que a questão ganhou maior visibilidade, não só pela pesquisa efetuada, mas pela organização de discussões, seminários e o estabelecimento de um fórum de interlocução entre as entidades que trabalhavam com o tema e os próprios gestores públicos. Fórum que teve não só o papel de transmitir para o Estado o conhecimento sobre esta população, mas constituir um espaço de diálogo onde foi possível imaginar, inventar e criar esta nova política.

As gestões de Paulo Maluf (1993-1996) e de Celso Pitta (1997-2000), em relação ao tema aqui analisado, possuem muitas semelhanças. Ambas foram marcadas por fortes conflitos com esta rede de atores, que no período anterior já começara a se articular mais intensamente. Alguns convênios foram fechados e muitos outros abertos. Entretanto, ao fechar os canais de diálogo e intervir nas práticas políticas construídas anteriormente, estas gestões permitiram o fortalecimento das alianças entre estes atores (ONGs, Fóruns, cooperativas e a Pastoral da Rua), em oposição às práticas da prefeitura. Apesar de haver, nestas duas gestões municipais, certa tendência à estagnação na atenção com a questão (Domingues Jr., 2003), é importante ressaltar que no final da gestão Pitta, como foi narrado por Padre Júlio, houve uma relativa aproximação da prefeitura com estes atores.

A regulamentação da Lei de Atenção à População em Situação de Rua, na gestão municipal Marta Suplicy (2001-2004), foi outro importante momento de alteração nas relações que gravitam em torno da população de rua. A aparição desta lei não só nomeou e constituiu juridicamente o grupo de interesse "população de rua", mas também estabeleceu formas institucionais de regulação das relações que conectam o morador de rua, passando pelas organizações mediadoras, até o Estado. Apesar de esta lei oficializar e formalizar, através de um direito específico e juridicamente reconhecido, uma série de demandas que foram se construindo ao longo do percurso temporal aqui narrado, é importante ter em conta que muitas premissas desta lei não foram seguidas ${ }^{39}$.

\footnotetext{
${ }^{39}$ Alguns dos efeitos institucionais da Lei de Atenção à População em Situação de Rua serão debatidos no terceiro capítulo deste trabalho. Mas deve-se atentar para o fato de que a mesma prefeitura que regulamentou esta lei, também a descumpriu.
} 
Outro elemento importante na trama desta história (e que em outro estudo deveria ser mais detidamente avaliado), é a já comentada razão estatística. Sabe-se que a estatística participa ativamente da construção de consensos cognitivos que regulam os debates, as divergências, as polêmicas e inclusive as críticas que refutam os indicadores. Como afirma Desrosière: "a construção de um sistema estatístico é inseparável da construção de espaços e equivalência que garantam a consistência e a persistência, ao mesmo tempo políticas e cognitivas, destes objetos destinados a fornecer a referência dos debates" (Desrosière, 1993). Assim, a informação estatística participa da própria construção da realidade, colocando em ação um conjunto de regras de comparação e medidas de equivalência que transformam coisas em "fatos sociais" portadores de um estatuto de objetividade que opera como parâmetro para o embate no espaço público (Telles, 2003).

No decorrer da década de noventa foram efetuadas seis contagens sobre a população de rua. Em cada uma destas contagens diferentes métodos foram utilizados, reavaliados e modificados, e em cada uma destas mensurações o número registrado apresentou um significativo aumento. No entanto, foi a primeira contagem, em 1991, que permitiu a abertura inaugural e eclosão histórica do discurso caracterizador da experiência de rua como um fenômeno de massa, como um fenômeno de população. Uma categoria que se refere, antes de mais nada, à própria razão de Estado, um modo de conhecimento político e administrativo, do qual a moderna arte de governo da vida dos homens é tributária (Foucault, 2001c, 2004). E é este conhecimento mensurável e quantificável que estabelece previsões estimadas e mecanismos reguladores sobre os aparelhos de gestão da população de rua em seu sombrio campo de aleatoriedade, imprevisibilidade e risco. Mas também é a razão estatística que baliza uma referência discursiva para os modos variados de representação desta população. Referência manejada não só por quem busca falar e agir sobre ela, mas também aqueles que falam em nome dela, tecendo críticas sobre os critérios e procedimentos de definição desta população como problema público.

Talvez outra dimensão importante a ser retida (e que em um outro estudo deverá ser melhor averiguada) é que durante a década de noventa, ao mesmo tempo em que a população de rua crescia em números estatísticos e se institucionalizava como uma questão pública, o Estado brasileiro passava por um importante processo de descentralização de algumas de suas atividades, tal como a da assistência. Esta descentralização veio desembocar, na cidade de São Paulo, na municipalização dos serviços da assistência social. Municipalização que acompanhou o impressionante crescimento das ONGs e projetos sociais de todo tipo com os, agora chamados, excluídos sociais. É válido, portanto, assinalar que a ampliação da rede de 
interlocutores políticos e institucionais, que armaram este campo de problematização da qual a população de rua constitui-se como pólo de gravidade, encontra ressonâncias em movimentos mais amplos processados no território metropolitano e na história da política brasileira.

Entre esta rede de interlocutores, uma linguagem foi urdida. Linguagem na qual vemos em jogo uma série de categorias discursivas que orientam ações e práticas: Povo da Rua, moradores de rua, população de rua, tempo de rua, acolhida, convivência, autonomia e albergues. E junto a estas categorias, se acopla também um conjunto lexical próprio ao universo do crescente mercado da gestão social: terceiro setor, parcerias, responsabilidade social, voluntariado, qualificação profissional, empreendedorismo, protagonismo, empoderamento e muitas outras. Estes termos que circulam hoje no mundo acadêmico, no interior do Estado e nos diversos projetos sociais ganharam dinâmica e vida próprias. Pode-se dizer que estas duas famílias de categorias (e provavelmente outras) fornecem referências para o estabelecimento de uma gramática de relações capaz de enunciar e, assim, ordenar discursivamente o campo institucional voltado à gestão da população de rua na cidade de São Paulo. Como o poder constituinte da linguagem é aquilo que permite, através de um conjunto indiscernível de relações, sustentar as coisas designadas por palavras e símbolos (Bahktin, 2006), é esta linguagem que fornece pontos de referência e o senso comum em relação aos quais os atores, aqui envolvidos, puderam qualificar, avaliar e dizer suas ações.

Entre um enorme acúmulo de informações, seminários, registros, discursos, livros, entrevistas, relatórios, amontoados de cadastros e saberes diversos sobre esta população, foi se estabelecendo uma rede de ligações, teias de pertencimento e reconhecimento, conexões de extensões variadas que foram se solidificando, ganhando consistência e transformando-se em espaços de equivalências um pouco mais estáveis. No entanto, o mais notável disso tudo é que a própria população de rua, mesmo com todo este imenso trabalho histórico de mediação e tradução, permanece ainda como uma categoria muito nebulosa, vaga e incerta. Numa pequena publicação da Secretaria da Assistência Social distribuída para usuários de equipamentos públicos e pessoas em situações de rua, no qual se indicava os possíveis locais de atendimento e se apresentava a lei na íntegra, havia apenas uma referência ao que seria caracterizado como "população em estado de abandono e marginalidade na sociedade" (SAS, 2001:14). Tal fato demonstra a dificuldade ou, então, a incapacidade de se definir publicamente, através de um instrumento jurídico, quem são precisamente os alvos desta lei. Vemos também, a partir desta definição deliberadamente abrangente e imprecisa, sobre o que é esta população, que a demarcação aberta e inconsistente dos sujeitos da lei acompanha o 
próprio movimento instável e ininterrupto desta intrincada trama de relações de poder e disputas simbólicas no qual se desenrola a história.

No entanto, para contar a história da população de rua - a história de sua definição, de seus nomes, de sua medida, das instituições destinadas a falar sobre ela, conhecê-la, contabilizá-la, reduzi-la, socorrê-la e protegê-la -, seria necessário atentar para muitos outros atores, eventos e processos que aqui apenas foram tangenciados. Mas, através das narrativas e trajetórias expostas, acredito ter sido possível observar duas dimensões desta história que acredito serem importantes para o tipo de abordagem aqui proposta.

Uma primeira dimensão é que no desenrolar dos processos narrados e vividos, se articulou um modo de específico de subjetivação na cidade, produzindo uma nova posição de sujeito. Esta trama histórica funcionou como um dispositivo mais amplo de interrogação, organização e constituição de novos sujeitos urbanos. E como o sujeito é constituído ativamente através de práticas de si que, contudo, não são criadas por ele mesmo, são esquemas que encontra embebido em seu meio, em seu círculo e nos jogos de relações nos quais está envolto, foi esta rede de práticas que permitiu a composição de um sujeito político na forma do Movimento Nacional de Luta e Defesa dos Direitos da População de Rua (MNPR). Ao tornar-se alvo de múltiplas interferências religiosas, demográficas, políticas e urbanas, esta realidade ganha forma, número, direito e um nome próprio que baliza uma luta por reconhecimento e redistribuição. Assim, de objeto, a população de rua passou a se colocar como um sujeito que busca tomar o poder da palavra sobre si - um sujeito que é falado e que agora passa a falar -, e neste processo apropria-se dos esquemas classificatórios e das convenções que se encontravam no meio em que fora historicamente produzido.

A segunda dimensão, a ser comentada, é que esta é uma história não estruturada e plena de desvios. Uma história que é resultado de sucessivos percursos e lutas moleculares travadas por agentes heterogêneos que foram se deslocando pelo campo social e possibilitando efeitos inusitados não lineares. Foi esta distribuição de agenciamentos - uma determinação "esparramada", porém articulada suficientemente para constituir-se enquanto uma formação discursiva referencial - que permitiu colocar a população de rua como um problema a ser enfrentado. Sobre isso Richard Rorty observa que Foucault, ao analisar os "problemas colocados para a política", não apela a nenhum "nós", nenhuma comunidade de consenso ou sujeito preexistente que o faça. (Foucault, 2002:20) Assim, os acontecimentos históricos e a decorrente aparição da população de rua como uma questão social na paisagem paulistana - mas também em outras partes do território nacional -, teriam de ser entendidos 
como resultado de uma multiplicidade causal que deu forma ao tema e das quais as trajetórias narradas possibilitaram entrever algumas de suas facetas. 


\section{Capítulo II: Política de rua}

Seguindo a hipótese, formulada em outro trabalho coletivo (Frúgoli Jr.; De Lucca; Aquino; 2006), de que nos últimos anos o campo de lutas em torno das ações políticas situadas e voltadas ao centro de São Paulo ampliou-se expressivamente, este capítulo busca contribuir para a compreensão da questão população de rua frente a este novo jogo de posições. Esta ampliação do quadro de conflitos mais recentes vincula-se, entre outras coisas, às próprias mutações urbanas em suas variadas dimensões econômicas e políticas, ao surgimento de novos personagens que passam agora a entrar em cena, bem como ao modo pelos quais estes atores aparecem e lutam para serem reconhecidos na arena pública como portadores de interesses variados, significados culturais e identificações políticas que balizam suas reivindicações materiais e simbólicas. A proposta deste capítulo é, a partir de um enfoque etnográfico centrado numa cadeia de relações dinâmicas entre poderes estatais e grupos sociais organizados, analisar a especificidade das conexões articulatórias que atravessam o fenômeno população de rua e o situa no interior de uma teia de discursos e processos de identificação, na luta pelo reconhecimento de certos direitos e demandas, mas também de diferenças existentes entre diversas categorias de sujeitos ligados às chamadas classes populares

No início do capítulo, busco expor sucintamente alguns aspectos contidos neste novo quadro de conflitos, tendo em consideração as especificidades da questão população de rua frente às transformações urbanas mais recentes, às alterações dos poderes públicos municipais e suas conexões com organizações e movimentos sociais da região. Na seção posterior, pretendo apresentar o instrumental teórico-metodológico do qual me utilizo para tratar e interpretar os eventos descritos e seus significados subjacentes. Mais à frente, será exposta uma seqüência de acontecimentos etnográficos, ocorridos com o advento da atual gestão municipal (PSDB-PFL), e que constitui o próprio material empírico para a análise. Na parte final deste capítulo, o conjunto dos eventos descritos será articulado de maneira a explicitar o entrelaçamento e a dinâmica das linhas de aliança e de clivagem ali presentes, bem como os jogos semânticos envolvidos nestas manifestações, no que se refere ao processo de produção da diferença e a decorrente construção de alteridades políticas. 


\subsection{Centro de tensões}

O próprio movimento histórico, no qual a população de rua foi se figurando e se configurando enquanto questão social, desliza sobre o compasso de uma multidão de agenciamentos que suplantam simples binarismos como local e global, atravessando transformações econômicas e metropolitanas que se interconectam e compõem novas referências, e passando, assim, a interferir e a trabalhar conjuntamente na redefinição do próprio estatuto da problemática. Assim, na passagem para o século XXI, o crescimento intensivo do fluxo de discursos, agentes e instituições, que desenha as linhas de força capazes de prover inteligibilidade ao fenômeno e posicioná-lo simultaneamente enquanto objeto e sujeito de ação política, é incitado também por todo um outro jogo de relações ativas e mais amplas que acompanha a própria dinâmica das mutações econômicas e políticas da cidade.

As redefinições e desagregações macroestruturais daquilo que é chamado contemporaneamente de "mundo fordista" (Harvey, 2002) segue de perto o desenrolar das novas realidades urbanas em mutação. Particularmente no caso paulistano, são várias as formas de nomear e interpretar tais alterações econômicas: reestruturação produtiva, inchaço do setor terciário, flexibilização do trabalho (ou mais precisamente, dos direitos que regem e regiam seus contratos), alargamento do mercado informal, das formas de subemprego e desemprego, e o acirramento da desigualdade de acesso a valiosos recursos de vida (Telles, 2006). Tudo isto sem falar nas profundas alterações que o próprio Estado brasileiro passou nestes últimos anos: o debate sobre a descentralização estatal e a influência (benfazeja ou não) dos poderes locais, a implementação de idéias e modelos de governo pautados por "virtuosos" projetos e programas políticos literalmente importados, as novas práticas gerenciais e administrativas entrecruzadas com as várias modalidades de subsídios e financiamentos nacionais e internacionais, o que torna, em alguns casos, muito problemática a linha divisória que separa os interesses públicos dos privados no interior das ações estatais (Kowarick, 2000). Assim, as alterações do capitalismo contemporâneo inflectiram fortemente sobre as recentes recomposições urbanas, abrindo um novo campo de debate sobre as atuais forças operantes na produção do espaço metropolitano, nos novos padrões de segregação urbana e desigualdade sócio-espacial, bem como sobre a nova geografia da pobreza que então se configura no território paulistano.

Não obstante, este conjunto de processos mais amplos afetou a própria maneira de vivenciar a experiência citadina paulistana. Além disso, tais processos inflectiram fortemente nas próprias pesquisas mais contemporâneas, que apontam para a necessidade de uma revisão 
crítica das clássicas categorias duais - centro e periferia - enquanto formas privilegiadas de organização e interpretação das múltiplas relações sociais urbanas (Arantes, 2000, Caldeira, 2000, Frúgoli Jr., 1995, 2000). Enquanto até a década de 90, a grande maioria dos estudos sobre pobreza em São Paulo restringia-se quase sempre às áreas periféricas da cidade, vemos nos últimos anos a proliferação de discursos variados, que apontam para a presença de setores significativos das classes populares na região central. Esta presença acompanha o próprio desenrolar histórico das relações sociais que transformaram e reconfiguraram a centralidade metropolitana.

Em São Paulo, a partir dos anos 60, houve um deslocamento do capital imobiliário, do investimento estatal e, por conseguinte, da centralidade urbana em direção ao vetor sudoeste da cidade (Frúgoli Jr. 2000). Assim o centro histórico, ao ser deixado pelas principais agências estruturadoras do espaço urbano, teve parte de seu ambiente construído abandonado e sem a regular manutenção, sofreu uma considerável transformação de uso em vários dos equipamentos instalados e uma significativa queda no valor imobiliário ${ }^{40}$. Notavelmente, o movimento posterior que buscou alavancar o processo de valorização nesta região, nomeou por "degradação" justamente a gradativa ausência de investimentos locais e a suposta apropriação deste espaço pelas classes mais baixas. Assim, a emergência histórica de um discurso caracterizador de um centro paulistano deteriorado - proferido principalmente por agentes preocupados em inverter tal quadro e tornar o centro um local atraente para investimentos imobiliários, turísticos e culturais - vai se formulando e se sofisticando no decorrer da década de noventa.

Atualmente, o centro de São Paulo caracteriza-se por ser uma arena aberta de embates sociais. Foco peculiar de interesses privados e públicos e, ao mesmo tempo, palco de lutas sociais por moradia, trabalho e direito ao uso dos lugares públicos, a região central encontrase hoje num intenso processo de transformação e negociação política pela construção social da paisagem urbana. De uma área vista como deteriorada, abandonada e perigosa, almeja-se transmutar a região central em um complexo centro de lazer, um sítio repleto de patrimônios com bares, restaurantes, museus e galerias sofisticados. Tal processo de apropriação cultural dos bairros históricos e centrais assemelha-se àquilo que alguns autores de língua inglesa,

\footnotetext{
40 Alguns trabalhos têm chamado a atenção para o fato de que em São Paulo o deslocamento do centro dominante é também resultado histórico de políticas públicas, no qual a sucessão de intervenções viárias tornouse um fator determinante para a crise do centro principal. Estas políticas pautaram-se por duas tendências: "obras visando uma significativa melhoria da macroacessibilidade para o automóvel no setor sudoeste da metrópole e o tratamento do centro como nó de articulação e passagem nessa grande estrutura" (Nakano; Campos; Rolnik, 2004:130). Assim, pode-se entender a chamada popularização do centro tradicional também como produto de políticas estatais historicamente direcionadas, no sentido de favorecer o acesso à região por meio do sistema de transportes públicos.
} 
como Smith (1996), Zukin (2000) e Harvey (2002) chamaram de gentrification ${ }^{41}$, intervenções urbanas estratégicas que buscam alterar significados históricos e impor novos usos e representações simbólicas de acordo com interesses de mercado.

A construção social da paisagem urbana, articulada às práticas de gentrification, refere-se, sobretudo à afirmação simbólica do poder, mediante inscrições urbanísticas que representem perspectivas e visões de mundo de grupos sociais que buscam apropriar-se e impor valores em certos espaços da cidade. Tais práticas políticas, via de regra, visam reverter processos de degradação urbana tendo como principal conseqüência a tentativa de mudança da composição social dessas áreas em favor de uma ocupação de classes sociais de maior poder aquisitivo. Estes investimentos concentrados nas centralidades urbanas articulam-se, mormente, com ações de expulsão ou controle de segmentos de baixa renda, como habitantes de moradias precárias e invadidas, trabalhadores informais, população de rua, prostitutas e outras categorias de atores provindos das classes populares. Entretanto, o contexto no qual o conceito de gentrification foi inicialmente urdido distingue-se dos atuais processos urbanos latino-americanos, principalmente pelo fato de que nestes últimos o Estado adquirir papel fundamental (Frúgoli Jr., 2005b). Apesar disso, pode-se destacar, como traço comum nestes processos, o forte caráter segregacionista e de controle da diversidade social.

Mesmo com o deslocamento da centralidade dominante para sudoeste e a suposta popularização da área, o centro histórico permanece como um espaço urbano de fundamental importância na articulação do conjunto da metrópole ${ }^{42}$. No centro de São Paulo há uma tensa e interativa coexistência entre dinamismo econômico e condições extremas de pobreza, reunindo numa só área um denso conjunto de características que o distingue de outros espaços da metrópole. É a localidade mais antiga da cidade e, por esta ter se iniciado lá, possui um grande valor histórico e patrimonial. Por ser uma nodalidade do sistema viário, tem o mais alto índice de circulação diária de pessoas: lá passam cerca de 2,8 milhões de pessoas por dia. Possui, também, o maior número de concentração de empregos e de imóveis desocupados, pois sua massa real de salários corresponde a cerca de 1/4 de todo município e sua taxa de

\footnotetext{
${ }^{41}$ Os autores conhecidos que aplicaram mais criteriosamente este conceito foram Neil Smith (1996) e Sharon Zukin (2000), que estudaram este processo em Nova York, e David Harvey (2002), que o fez em Baltimore, ambas cidades norte-americanas. Em algumas publicações brasileiras foi adotada a expressão "enobrecimento" para o termo. Mesmo tendo em consideração que esta é a melhor tradução para o português, utilizo a expressão original de língua inglesa, pelo fato do termo "enobrecimento" reter uma importante imprecisão: refere-se ao "nobre" como categoria de sujeitos de um processo que é, em geral, e particularmente no Brasil, relacionado mais a uma estratificação social por renda do que por um sistema de status.

${ }^{42}$ Vale comentar que esta é uma importante diferença do processo de reestruturação urbana do centro de São Paulo em relação a outros estudos sobre as práticas de gentrification no Brasil, como em Recife (Leite, 2004) e Salvador (Fernandes, 1995): tratam-se de cidades onde as localidades históricas sob intervenção são mais circunscritas e não possuem a função de espaços centrais na articulação da malha metropolitana.
} 
vacância aproxima-se atualmente dos $20 \%^{43}$ (Comim, 2004). Nesta região, há uma complexa rede de relações interligando e canalizando o intenso fluxo de recursos materiais e simbólicos entre as variadas pessoas, agrupamentos e coletivos, com diferentes posições de classe, prestígio e acesso, e que se utilizam diariamente deste espaço como lugar de passagem, trabalho, moradia, lazer ou estratégia cotidiana de sobrevivência.

Ao tornar-se foco de atenções e olhares variados, o Centro ganhou visibilidade, passando a exibir mazelas que até então eram vistas como exclusivas dos bolsões de pobreza da metrópole. De um lado, poderíamos atribuir a presença popular na região como elemento decorrente de uma real diversificação do tecido metropolitano na última década, tornando mais complexa e heterogênea as configurações sócio-espaciais, suas desigualdades de acesso, a interpenetração mais intensa entre espaços centrais e periféricos da cidade, bem como o aumento da pauperização urbana, das carências habitacionais, precariedades laborais e outras vulnerabilidades sociais registradas (Marques; Torres, 2005). De outro lado, o recente reconhecimento da presença de setores de baixa renda na região central poderia ser atribuído também ao fato de que talvez estes atores já estivessem se utilizando deste espaço urbano, sendo que só agora, quando esta região passou a se constituir enquanto alvo privilegiado de discursos e interesses plurais, é que se tornaram visíveis enquanto problemas urbanos a serem enfrentados.

Historicamente, a região central sempre se caracterizou pela presença das classes populares (Frehse, 2005), no entanto, ao que tudo indica, esta presença adquiriu recentemente outro significado ao conectar-se diretamente com certas ordens discursivas contemporâneas, que culpabilizam as camadas mais pobres como responsáveis pela própria degradação urbana do Centro. Vemos então que no desenrolar dos últimos anos, período este em que a população de rua institucionalizou-se como questão social e pública na cidade, o território existencial no qual este contingente desenvolve suas subjetividades e atividades diárias também passou a se constituir como foco privilegiado de intervenções políticas. Assim, a intensificação de discursos e práticas voltadas ao universo da rua conecta-se diretamente e é amplificada pelas atuais preocupações urbanas mais recentes em revitalizar a região central ${ }^{44}$. Processo este, no

\footnotetext{
${ }^{43}$ Esta vacância imobiliária acentuada no centro de São Paulo, a maior parte caracterizada por prédios vazios, possui proprietários que buscam lucratividade através de outras alternativas de obtenção de renda, e que muito provavelmente aguardam uma revalorização destes imóveis, a partir da possível implementação de políticas urbanas de "revitalização" (Bomfim, 2004).

${ }^{44}$ No capítulo anterior, esbocei uma história do nascimento da população de rua a partir dos atores sociais e do tecido relacional nos quais estes se inseriam. Contudo e apesar de todo esforço empreendido, talvez tenha criado uma certa distância entre esta história e as transformações macroestruturais urbanas. Seria, pois, necessário atentar mais detalhadamente para o estreitamento dos laços de interdependência existentes entre os processos que levaram o centro antigo e a população de rua a se tornarem alvo de intervenção urbana, visto que a tentativa
} 
qual as alterações do poder municipal acompanharam e produziram importantes mudanças na dinâmica das diversas forças, relacionadas à população de rua e às intervenções urbanas no Centro como um todo.

Sabe-se que a primeira gestão municipal a se preocupar em formular políticas voltadas a este contingente populacional e elaborar projetos de intervenção na região central foi a prefeitura de Luiza Erundina (PT, 1989-1992). Contudo, no decorrer da década de noventa, as gestões posteriores de Paulo Maluf (PPB, 1993-1996) e Celso Pitta (PPB, 1997-2000) tiveram um desempenho secundário no que se refere às elaborações de políticas sociais e programas de intervenção urbana na região. Sendo que, no que se refere ao último aspecto comentado, a principal protagonista foi a Associação Viva o Centro, criada em 1991. Uma das principais tarefas desta associação fora justamente pressionar o poder público para a realização de um conjunto de ações pela "revitalização" do Centro através de laudos e pareceres técnicos, da formulação de projetos urbanísticos e paisagísticos, e de eventos, publicações e outros discursos públicos, de maneira a fornecer maior visibilidade ao tema e angariar maiores $\operatorname{parcerias}^{45}$ (Frúgoli, 2000).

Concomitante a este processo, o conjunto das organizações e entidades sociais que trabalhavam com a população de rua foram aumentando em número e também passaram a pressionar a prefeitura, através de inúmeros protestos e manifestações públicas, para que esta não fechasse os convênios já existentes e que colocasse fim aos procedimentos diários de expulsão de moradores de rua dos espaços públicos. Estas organizações também reivindicavam a abertura de canais de interlocução para a implementação e a formalização de novas políticas sociais, voltadas para este contingente populacional. Esta articulação entre as entidades se fazia preferencialmente através do Fórum das Organizações que Trabalham com a População de Rua, que fora inicialmente concebido durante a gestão Erundina para ser um espaço de diálogo entre poder público, entidades sociais e também alguns representantes da

\footnotetext{
de transformação de valor dos espaços urbanos e o aumento dos dispositivos institucionais para o controle dos contingentes homeless parecem ser fenômenos conjugados também a processos transnacionais, já que têm ocorrido em outros contextos mundiais, como os Estados Unidos (Davis, 1993, Zukin, 2000) e a Europa Ocidental (Wacquant, 2001).

${ }^{45}$ A dinâmica de atuação desta associação pode ser apreendida por quatro ações principais: a) diagnósticos técnicos urbanísticos b) um trabalho de divulgação positiva do centro, c) a sensibilização dos poderes públicos para as questões do centro e d) a busca de parcerias entre o poder público e a iniciativa privada. Esta associação foi a principal responsável pela formulação de demandas sistemáticas de "revitalização" e posteriormente "requalificação" da área, que lograram certa repercussão na opinião pública, dirigidas aos governos federal, estadual e, principalmente, municipal, em um nítido esforço de imposição de usos e sentidos que atendem a interesses muito restritos, em favor de uma freqüência de classes mais abastadas. Com efeito, as principais ações no sentido de promover uma gentrification seguiram os preceitos de se restaurar prédios de valor arquitetônico e histórico como forma de atrair um novo público de maior poder aquisitivo para a região e, desta maneira, mais investimentos (Frúgoli Jr., 2000).
} 
população de rua. Apesar da má comunicação e dos conflitos entre prefeitura e entidades de atendimento, foi devido a este antagonismo em relação às gestões Maluf e Pitta que as entidades puderam se unir, coligando e sedimentando interesses comuns, e, permitindo assim, a construção do projeto da Lei de Atenção à População de Rua, resultado das próprias demandas políticas identificadas e que foram elaboradas conjuntamente neste período.

Deste modo, tanto no que se refere ao processo de intervenção urbana no centro, quanto à construção de políticas focais para a população de rua, as gestões municipais de Paulo Maluf (1993-1996) e Celso Pitta (1997-2000) foram alvo de pressão política por diversos atores participantes da chamada sociedade civil organizada, que buscavam abrir canais de interlocução e entendimento. Entretanto, é preciso frisar que estes atores, ao adotarem uma postura de pressão em relação à prefeitura, tinham projetos e interesses muitos distintos. Enquanto a Associação Viva o Centro vincula-se a setores da economia, serviços, comércio, instituições privadas e outros órgãos de caráter empresarial, o conjunto das entidades sociais, ONGs, pastorais e cooperativas ligadas à população de rua aproximam-se muito mais das experiências ditas comunitárias e de base popular católica.

A partir de 2001, assistimos a uma expressiva mudança no processo de intervenção urbana em curso no centro de São Paulo, bem como no jogo de relações dos atores vinculados à população de rua. Nas duas gestões anteriores, o Centro e suas problemáticas sociais específicas não eram questões prioritárias para a prefeitura, fato que proporcionava maior visibilidade para as associações, entidades e outras organizações não governamentais em suas demandas políticas, tanto no que se refere à "requalificação" do centro, quanto à "exclusão social" vivida pelos setores mais pobres. Contudo, a partir de 2001 a nova gestão de Marta Suplicy (PT, 2001-2004), ao buscar assumir claramente o papel de protagonista nas diretrizes das operações urbanas e nas formulações de políticas sociais para a região, altera significativamente a posição do poder público neste campo de correlações de forças.

Através do programa "Reconstruir o Centro", a nova prefeitura propõe uma série de operações e normas formais orientadoras de ações políticas no sentido de uma reorganização no processo de intervenção local. Dentre estas, se destacam propostas que num certo sentido buscavam dialogar com as demandas já existentes por trabalho e moradia popular na região, visto que muitos de seus princípios foram pautados por reivindicações produzidas anteriormente através de uma multiplicidade de experiências históricas entrecruzadas, como a Comunidade dos Sofredores de Rua e organizações sociais, associações e cooperativas de 
reciclagem, além de movimentos populares que então passam a atuar na área ${ }^{46}$. Sem querer adentrar nos aspectos oficiais e legais destes programas (bem como seus limites), vale apenas apontar que este conjunto de ações formais produziu uma importante reorientação no conjunto de prioridades, fornecendo certo destaque para a questão social presente na região.

Ao abrir espaço para a interlocução com determinadas organizações e grupos vinculados a certos interesses populares, a prefeitura pôde assumir parcialmente algumas demandas sociais historicamente construídas por estes atores, destacando-se entre estes, aqueles ligados ao universo da rua. Não por acaso, a primeira atitude da então empossada prefeita foi justamente regulamentar a Lei de Atenção à População de Rua, que estabeleceu a obrigatoriedade do poder público em manter uma série de serviços também contemplados na lei, de maneira a garantir os mínimos sociais a esta população. Um ano depois, quando a Secretaria Municipal da Assistência Social foi assumida por Aldaíza Sposati (uma das principais formuladoras e autoras da mesma lei), foi lançado o "Projeto Acolher Reconstruindo Vidas". Este projeto, concebido com a intenção inicial de extrapolar a esfera assistencial, se pautou por uma inovadora proposta intersecretarial que, contudo, nunca veio a se efetivar ${ }^{47}$.

Ao incorporar em seu governo alguns componentes presentes nas variadas demandas construídas no decorrer da década de noventa, a gestão Marta toma a frente dos processos na construção de políticas, tanto para a "inclusão social" da população de rua, como para a "requalificação" da região. Processos estes que anteriormente eram encampados fundamentalmente por organizações não governamentais e outras formas de associativismo. Assim, os deslocamentos ocorridos nesta constelação de forças poderiam ser atribuídos ao novo papel que a gestão local passa a assumir a partir de 2001. Contudo, me parece ser um equívoco sustentar que a mudança, ampliação e diversificação das forças atuantes neste campo de conflitos seja algo unicamente atribuído às alterações públicas dos poderes instituídos. Principalmente porque, na entrada do novo século, assistimos à emergência de modos de agenciamentos urbanos que até então não se faziam presentes nesta paisagem.

Uma destas modalidades de agência são os investimentos internacionais, conectados a dinâmicas, fluxos de interesses e capitais transnacionais, promovidos justamente com o

\footnotetext{
${ }^{46}$ Tal programa passou por várias mudanças nos anos seguintes, incluindo a obtenção de recursos do BID para sua concretização. Entretanto, ao que tudo indica, os canais de diálogo abertos pela prefeitura mudaram de natureza no transcorrer do mandato e não satisfizeram as expectativas dos grupos participantes (Frúgoli Jr.; De Lucca; Aquino, 2006).

${ }^{47}$ Os efeitos e os impactos da Lei da Atenção à População de Rua e as transformações institucionais decorrentes das alterações dos poderes públicos serão expostos no próximo capítulo. Vale, contudo, apontar que é a partir desta gestão que a rede de atendimento é ampliada e ganha impulso definitivo, ao fortalecer-se legal e institucionalmente.
} 
propósito de intensificar o processo de transformação urbana e revalorização da região central. Estes recursos, provindos de órgãos conectados à chamada "cooperação internacional" - como o BID (Banco Interamericano de Desenvolvimento) e mais recentemente a UE (União Européia) -, ao fornecer subsídios financeiros às práticas de operação urbana, permitem alavancar significativamente o poder de intervenção pública, apesar de normalmente restringir o horizonte possível das práticas políticas. Isto se faz, pois estes recursos chegam quase sempre acoplados a programas e diretrizes de ação com certos objetivos já previamente definidos. Contudo, outras modalidades de agenciamento também começam a se fazer mais presentes neste cenário, e são especificamente sobre estes modos de ação que, a partir de agora, pretendo me deter.

\subsubsection{Novos atores em movimento}

Devido à presença maciça das classes baixas na região central, os segmentos populares são fundamentais na dinâmica das relações locais. Relações que muitas vezes deixam de ser simplesmente "locais" e passam a se conectar a outros territórios da metrópole e do país. Além disso, através de articulações variadas com outros interlocutores políticos, alguns destes segmentos populares têm desenvolvido um importante papel nos processos de disputa pela apropriação espacial e negociação política em torno da transformação desta paisagem urbana. $\mathrm{Na}$ forma de movimentos sociais, e apoiados por outros atores e organizações sociais, certas categorias das classes populares podem assumir o papel de protagonistas, no enfrentamento com organismos governamentais e na luta por reivindicações e demandas construídas.

No final da década de noventa, os movimentos de luta por moradia dão início a invasões organizadas de prédios e terrenos no Centro, trazendo forte visibilidade ao tema. Ao atuar nesta região da cidade, que possui uma alta taxa de vacância, estes movimentos têm como principal meta pressionar o poder público para que este desenvolva medidas de solução para o problema do déficit de habitações sociais. Para tanto, eles têm adotado duas linhas de ação: 1) ocupações de prédios abandonados, resistindo às reintegrações de posse e esperando sua desapropriação para uma ocupação definitiva; 2) ocupação de prédios públicos como forma de chamar a atenção do poder público para a questão da habitação. E nestas duas modalidades de atuação, estes movimentos têm sofrido constantemente tentativas de contenção pela polícia ${ }^{48}$.

\footnotetext{
${ }^{48}$ Há pelo menos quatro movimentos de moradia proeminentes atuando no Centro: Unificação das Lutas de Cortiço, Movimento Sem-Teto do Centro (MSTC), Movimento de Moradia do Centro (MMC) e o Fórum dos
} 
Também neste período, as cooperativas de catadores de materiais recicláveis, concebidas historicamente através de diversos itinerários individuais e coletivos ligados às experiências de rua e ao trabalho diário junto ao lixo, passam a adquirir outros contornos e a ganhar maior consistência na cidade de São Paulo. Neste processo, entidades sociais como a OAF e o Centro Gaspar Garcia de Direitos Humanos ganham importante destaque, já que foram as principais apoiadoras e parceiras na construção das duas primeiras cooperativas da cidade, respectivamente a Coopamare e a Coorpel. Com o tempo, as trajetórias destas cooperativas passam a se vincular com outros coletivos de catadores que vão surgindo na região central, mas também passam a se conectar politicamente com experiências de organização e de trabalho que ultrapassam o território metropolitano, encontrando referências e ressonâncias em outras partes do país. Esta crescente interação entre uma miríade de percursos, ao expandir geograficamente suas relações e atravessar processos históricos plurais e interligados, permitiu a constituição de um movimento social, fundamentalmente urbano, em escala nacional ${ }^{49}$.

Atualmente, o Movimento Nacional de Catadores de Materiais Recicláveis (MNCR) possui como principal meta a organização da categoria, a luta pelo reconhecimento público desta atividade. Nesse sentido, coloca-se numa posição totalmente contrária à privatização do saneamento básico e do lixo urbano. A organização que o movimento busca baseia-se nos princípios da economia solidária, e possui, como objetivo último, o controle de tecnologias que garantam o domínio de toda a cadeia produtiva, desde a execução da coleta até o beneficiamento final dos materiais. Para isso, o MNCR tem articulado as diversas

Cortiços. Apesar deste trabalho não possuir como foco de discussão os movimentos de luta por moradia, esta rápida apresentação se faz necessária, pois algumas das organizações aqui citadas aparecerão pontualmente nos eventos etnográficos descritos e servirão como apoio e elemento contrastivo, para a posterior análise dos processos de identificação e enunciação pública da população de rua. Vale apontar também, que parte das informações aqui contidas, sobre os movimentos de moradia, foram construídas em interlocução direta com a pesquisa de Carlos Aquino, ainda em andamento. Um esboço inicial desta interlocução também pode ser visto em: Frúgoli Jr.; De Lucca; Aquino; 2006.

${ }^{49}$ Como já comentado no capítulo anterior, o MNCR foi fundado em junho de 2001 em Brasília, por ocasião da $1^{\text {a }}$ Marcha Nacional da População de Rua, com a presença de mais de três mil catadores e moradores de rua de todo país. Contudo, é importante assinalar que enquanto o MNCR possui acesso a alguns canais de interlocução com o governo federal (visto que em 2004, este movimento efetivou, junto ao Ministério do Desenvolvimento Social e Combate a Fome, um convênio para a capacitação de lideranças e organização de novas cooperativas) na grande maioria das cidades brasileiras tais espaços de diálogos com os poderes públicos locais são inexistentes, sendo que muitas prefeituras atuam mais como instâncias que dificultam, quando não impedem, o trabalho dos catadores. Aparentemente, o MNCR possui grande flexibilidade de modo a incorporar as enormes diferenças locais entre as cooperativas e associações distribuídas pelo território nacional. As cidades onde o MNCR é mais ativo e se faz mais presente, são justamente as maiores metrópoles brasileiras. Em especial, São Paulo, Belo Horizonte, Salvador e Porto Alegre. No caso de São Paulo, o MNCR dividiu o território da cidade em cinco zonas de atuação: centro, norte, sul, leste e oeste. Esta regionalização intra-urbana corresponde, cada uma, a subcomitês respectivos que, juntos, formam o comitê de articulação da cidade de São Paulo. O subcomitê da região central é o mais articulado internamente e o mais importante, não só por ser o mais antigo, mas também por ser esta a região que mais produz material “de qualidade” para a prática de catação na cidade. 
cooperativas e coletivos de catadores, de maneira a formar "redes solidárias de comercialização e trabalho" e, assim, acumular material suficiente para a venda direta às grandes empresas de reciclagem e indústrias. Este procedimento permite reter mais renda para os catadores, já que possibilita a independência em relação aos "depositários", "aparistas" ou "atravessadores", figuras estas que atuam na rede informal da reciclagem, acumulando o material vendido individualmente por baixíssimos preços, e revendendo-o a preços mais elevados para as grandes indústrias. Estes intermediários são vistos e tratados pelo MNCR como os verdadeiros "exploradores" dos catadores, já que nesta transação comercial abocanham toda renda diferencial produzida pelo trabalho da catação ${ }^{50}$.

Estes são os princípios e procedimentos mais gerais, que articulam a enorme heterogeneidade de experiências e vivências de base espalhadas pelo país. Apesar desta aparente "ordem" interna, é necessário dizer que este esquema é muito geral e que dificilmente se realiza do modo planejado. Isto porque os impasses e bloqueios cotidianos enfrentados por estes atores são bem complexos. Tanto no espaço público da rua, quanto no interior destas unidades de trabalho, as atividades são mormente desenvolvidas mediante condições extremamente precárias. Estas dificuldades vinculam-se, entre outras coisas, à extrema e constante escassez de recursos materiais - como verbas para a compra de equipamentos de trabalho e proteção individual, para a manutenção dos espaços físicos freqüentemente inadequados, e para a reprodução da vida familiar e pessoal dos trabalhadores como um todo -, mas também simbólicos - a desqualificação profissional em relação ao gerenciamento coletivo da atividade, em relação ao domínio dos instrumentos legais e burocráticos, sem falar do não reconhecimento da profissão e sua forte estigmatização pública, o que produz constantes atritos e desentendimentos com autoridades e outros agentes urbanos.

Como foi no Centro que se iniciou o processo de organização dos catadores em São Paulo, também é nesta região da cidade que as cooperativas são mais articuladas. Nesta área existem pelo menos oito unidades de trabalho, que funcionam como cooperativas, associações ou espaços coletivos informais - e, em alguns casos, ilegais - para a atividade conjunta de acumulação, triagem e posterior venda do material, procedimento que os próprios catadores chamam de "reciclagem". Também é nesta região, mais especificamente na Baixada do

\footnotetext{
${ }^{50}$ É conhecido que os donos dos depósitos muitas vezes "pagam" parte do material coletado pelos carroceiros com bebidas ou disponibilizando um espaço, em meio ao entulho, dentro de suas instalações, para que o catador more só ou com sua família. A maioria dos depósitos são construídos em terrenos baldios ou casas alugadas, ou até casas invadidas, o que pode facilitar sua peregrinação clandestina, mudando o ponto do depósito, em caso de fechamento por parte da prefeitura.
} 
Glicério, que se localiza a secretaria nacional de articulação do MNCR. Apesar do proferido discurso sobre a auto-organização e auto-gestão das unidades de trabalho, o processo de gestão das cooperativas conta com a ativa participação de outros agentes e assessorias. Atualmente, nesta região da cidade, estes "apoios técnicos" ou "parcerias" são exatamente algumas das principais organizações que trabalham com a população em situação de rua. Isto não por acaso, já que a quase totalidade das cooperativas do Centro surgiu do histórico trabalho das entidades com este contingente. Sobre isto, é importante salientar que a esmagadora maioria dos catadores da cidade permanece atuando individualmente sem qualquer vínculo com coletivos de trabalho ou com o MNCR, sendo que no Centro muitos destes se encontram trabalhando e vivendo em situação de rua.

Mais recentemente, vimos o nascimento do Movimento Nacional de Defesa e Luta pelos Direitos da População em Situação de Rua. Este movimento, que ainda está em processo de construção e surgiu no final de 2004, tem em sua titulação justamente seu principal objetivo: a busca pela consolidação dos direitos adquiridos. O MNPR, desde seu nascimento, esteve sempre próximo ao MNCR, e como este último, também se apresenta como um movimento de escala nacional. Contudo, o MNPR possui articulações em poucas cidades brasileiras, sendo as principais São Paulo e Belo Horizonte. Cidades onde, justamente, a Pastoral do Povo da Rua é mais ativa. Mais recentemente, este movimento tem aumentado o número de seus membros, sendo que no início era composto fundamentalmente por apenas três lideranças na cidade de São Paulo, todas possuindo trajetórias de rua ${ }^{51}$.

Em São Paulo, suas ações têm se desenvolvido basicamente no sentido de pressionar a prefeitura para que cumpra efetivamente a Lei de Atenção à População de Rua. E para tal, adotam modos de ação e práticas muito distintas. Entre suas estratégias de atuação, pode-se destacar: a organização de protestos e manifestações de rua; o sucessivo envio de ofícios ao Ministério Público delatando ilegalidades cometidas pela prefeitura e a decorrente abertura de inquéritos judiciais; o preparo de debates coletivos com a presença de gestores públicos, representantes de entidades e moradores de rua; presença em fóruns, conselhos e outras instâncias participativas que de uma maneira ou outra tangenciam o tema; e a frequiência e circulação, ainda que baixa, entre equipamentos e instituições de atendimento à população de rua, de modo a discutir, junto com os usuários, dificuldades vividas e o uso de seus direitos. Vale comentar que esta última atividade é a que mais se aproxima da chamada "volta às

\footnotetext{
${ }^{51}$ Apesar de ter aumentado o número de participantes, até o fim da pesquisa estas três lideranças permaneciam ativas. São elas: Sebastião Nicomendes, Anderson Lopes e Carlos Henrique Aquino. Estes dois últimos foram entrevistados, em momentos diferentes da pesquisa.
} 
bases" ou "basismo", práticas estas muito comentadas nos estudos iniciais sobre movimentos sociais urbanos e que correspondiam à "necessidade de se 'ouvir' as bases, às quais caberia sempre tomar as decisões" (Singer; Brant, 227:1976).

Nota-se, também, que apesar das constantes críticas às instituições filantrópicas e suas supostas dimensões "pilantrópicas" (comentadas no capítulo anterior), as ações e articulações deste movimento são muito dependentes do apoio das entidades que desenvolvem projetos sociais com a população de rua. Inicialmente, na cidade de São Paulo, o MNPR utilizou, como sede e escritório, uma sala localizada na Baixada do Glicério, em um projeto de moradia provisória coordenado pela OAF. Posteriormente, o escritório passou para um outro projeto social, também voltado à população de rua, este agora coordenado pelo SEFRAS (Serviço Franciscano de Solidariedade) e localizado próximo ao largo São Francisco. Mais recentemente (já em 2007), sua sede voltou a situar-se na Baixada do Glicério, só que agora numa sala dentro de um grande galpão, coordenado pelo MNCR e utilizado, principalmente, para o armazenamento, pesagem, beneficiamento e comercialização do material reciclável coletado $^{52}$.

Este rápido deslocamento do escritório do MNPR na cidade de São Paulo ilumina pelo menos um aspecto deste movimento: sua dificuldade de se estabilizar, num dado espaço de relações, em meio às controversas e instáveis ligações com as entidades e organizações que o apóiam. Também é importante destacar que, devido à sua breve trajetória, de apenas três anos, é muito difícil estabelecer contornos mais estáveis e parâmetros capazes de caracterizar este movimento mais adequadamente. Contudo, o item anteriormente ressaltado - a falta ou dificuldade de lidar com as "bases" locais -, certamente é um elemento que diferencia o MNPR, em sua organização interna, dos outros dois tipos de movimentos sociais anteriormente apresentados.

\subsection{Rituais públicos}

Ainda que sob o risco de simplificar a realidade estudada, apresentei acima um amplo leque de atores, itinerários e transformações, com a intenção de melhor expor o cenário histórico onde se desenrolam os eventos que textualmente serão exibidos. Sem este mapeamento preliminar dos espaços de relações e posições, não seria possível extrair

\footnotetext{
${ }^{52}$ Este galpão constitui a sede o "Projeto Cata Sampa", financiado pela Petrobrás e coordenado pelo MNCR e pela OAF. Este recente projeto tem como objetivo o fomento à formação e consolidação de uma "rede solidária de comercialização e trabalho", em parte da cidade de São Paulo e Baixada Santista.
} 
adequadamente os significados culturais e sociopolíticos subjacentes à seqüência de acontecimentos narrados. Isto porque esta seqüência demonstra apenas uma sucessão de estados que, tomados apenas em si mesmos, não significam muita coisa. São momentos e instantes inseridos numa corrente interacional de processos plurais. Processos que trazem à superfície da experiência social, lutas, sedimentos e formas passadas, obrigando os atores engajados a um constante trabalho de tradução e manuseio dos signos e discursos situacionalmente acionados.

Historicamente, os estudos dos movimentos sociais transformaram-se em um fértil campo para a análise dos processos de construção identitária. Alguns destes estudos mostraram como certas experiências coletivas elaboram, no cotidiano e na vivência ordinária, valores e carências, positividades e negatividades (Durham, 2004, Evers, 1984). Estes estudos mostram como estas elaborações não são simplesmente dadas. São, sim, resultado de um permanente, intenso e ativo trabalho de ordenação e interpretação do mundo. Trata-se de um trabalho de apropriação e tradução efetuado pelos próprios envolvidos com os movimentos e mobilizações coletivas. Estes atores atribuem significação à experiência vivida a partir das memórias, dos repertórios de linguagem, das formas de vida passada e dos enredos disponíveis em seu meio. Meio esse que é permanentemente desestabilizado pelas transformações históricas, fazendo com que as próprias construções discursivas sobre si e outros, sejam, também, permanentemente redefinidas, de acordo com as situações e necessidades presentes.

Contudo, muitos destes estudos, ao privilegiarem as dimensões cotidianas, algumas vezes contribuíram para uma interessante, mas limitada, "análise internalista" dos movimentos sociais (Silva; Ribeiro, 1985). Este tipo de abordagem, ao reafirmar dicotomias, como dentro/fora, corre o risco de não considerar aqueles que supostamente seriam seus "agentes externos", dificultando, assim, a devida atenção às relações que cruzam todos os movimentos sociais e que, ao mesmo tempo, dão suportes a estes. Assim, a proposta aqui empreendida, articula-se com este conjunto de estudos, com a diferença de que se deseja ler mobilizações coletivas não a partir da experiência ordinária, mas sim extra-ordinária, além de privilegiar menos as identidades e mais os processos de identificação.

A primeira distinção é de ordem empírico-metodológica, já que as situações sociais descritas não se referem às habituais práticas do dia-a-dia e sim a momentos excepcionais, carregados de tensão e saturados de significados diversos. São jogos absorventes e agonísticos, onde os jogadores sentem a estranha sensação de estarem "separadamente juntos" (Huizinga, 15:2004). A segunda distinção é mais teórica e busca deslocar o problema 
substancial da identidade, em direção ao seu processo de enunciação performática (Butler, 2001). Processo este que impede a imagem de uma totalidade identitária, buscando sempre, em sua vacilante fronteira, um reconhecimento capaz de refletir no outro, o mesmo ${ }^{53}$.

A análise aqui proposta busca iluminar o jogo de relações no qual se situam, preferencialmente, dois dos movimentos sociais anteriormente comentados (MNCR e MNPR), suas formas de reconhecimentos, as categorias e signos mobilizados para isso, bem como refletir sobre a posição de outros atores sociais em relação a estes. Ao traçar cruzamentos e conexões entre distintos eventos, onde carências são explicitadas, demandas são reivindicadas, e, neste processo formas simbólicas são lançadas ao espaço público do Centro, torna-se possível estabelecer certas diferenças e semelhanças entre as diversas disposições e imagens expressas. Esta análise também possibilita esclarecer um pouco mais a recente diversificação e ampliação da arena de conflitos na região central e o papel da atual gestão local, que, visando "limpar o Centro", afeta um conjunto mais amplo de atores, desencadeando reações, algumas vezes imediatas, por parte dos atingidos.

Deste modo, o foco principal da análise destes rituais vincula-se a dois objetivos entrelaçados: 1) uma qualificação das relações entre os atores manifestos e em confrontação; 2) e das identificações produzidas discursivamente, tendo como eixo diferencial o discurso da população de rua.

Para isso, trato as manifestações, aqui descritas, como rituais públicos. A utilização dos dois termos é deliberada. Rituais, pois o argumento busca enfatizar a dimensão simbólica e expressiva das movimentações e manifestações sociais. São maneiras e momentos específicos pelos quais atores diferenciados mobilizam imagens, palavras e símbolos. Visto que a cultura é dinâmica, aberta e pública, o manejo de seus significados também o é (Geertz, 1989). Entretanto, os efeitos destes manuseios são irregulares, díspares e desiguais. Esta dimensão pública, plurivalente e, portanto, polêmica do significado, faz deste a arena de uma luta, desembocando numa necessária politização dos signos culturais e seus usos (Bakhtin, 2006). Assim, estes ritos também são rituais políticos, pois, ao confrontar simultaneamente posições e repertórios semânticos distintos, contestam categorias, deslocando, ainda que liminarmente, perspectivas canônicas. Ao colocar em movimento uma combinação de forças e formas, estes rituais públicos permitem evocar relações e conflitos até então ocultos,

\footnotetext{
${ }^{53} \mathrm{Na}$ conclusão, voltarei a este problema, mas por enquanto vale apenas comentar que, como Laclau (1986) e Bhabha (2006), compreendo a identidade como um significante vazio e que encontra baliza apenas em sua ambivalente diferença.
} 
possibilitando a afirmação de relações, posições e modos de subjetivação, tornando reconhecíveis formas e sentidos até então desconhecidos.

Ao discorrer sobre as relações de poder, o terreno da cultura e o modo nos quais certos movimentos sociais desenvolvem suas práticas de enfrentamento, Stuart Hall diz que o termo ritual aponta para “a estilização das ações sociais, o 'jogo' dos signos e símbolos, a 'encenação' da resistência e da repetição nos teatros da vida cotidiana, o 'efeito bricoleur' da dissociação de fragmentos e emblemas de um discurso cultural e sua reassociação em outro" (Hall, 229:2003). Esta abusada linguagem metafórica e imagética é acionada justamente na tentativa de ler os significados embutidos nestas cenas estratégicas e o que revelam ou podem revelar. Estes rituais produzem narrativas, constituem enunciados coletivos. São discursos que orquestram perspectivas heterogêneas, mas também antagônicas. Eles evocam jogos de diferenças e equivalências, publicizam relações de proximidades e distâncias. Todas estas linhas de clivagem e aliança política são encenadas situacionalmente.

Um ritual pode ser tratado como um ato dotado de certas convenções práticas, através das quais os participantes manifestam seu envolvimento, engajamento e consideração por um determinado objeto ou objetivo. Contudo, fixar o que é um ritual apenas empobrece e dificulta sua análise, já que sua definição nunca pode ser dada de antemão, ela é sempre etnográfica. $\mathrm{O}$ importante é saber notar o que os jogadores, ao jogarem, estão indicando como sendo um evento especial, um momento importante que é parte integrante de um jogo mais amplo e intenso. Interessa também observar que ele tenha uma forma específica e perceptível, uma temporalidade e espacialidade própria. Assim, estes rituais constituem-se enquanto ponto de observação pública em torno das trocas simbólicas e das interações em momentos de encontros e confrontos coletivos (Joseph, 2000; Goffman, 1974, 1985).

Contudo, não há como negar que, ao construírem discursos públicos sobre si e sobre outros, estes agenciamentos de enunciação assumem certas dimensões performáticas, dramáticas e teatrais. Contudo, a performance ali desenvolvida não se trata de um ato único e desprendido, já que é sempre uma reiteração de um conjunto de relações passadas. Na medida em que a performatividade adquire o status de ato no presente, ela oculta ou encobre convenções das quais é uma citação histórica. Não por acaso, ao tratar a performatividade como citacionalidade, Judith Butler comenta que o "ato não é primariamente teatral; de fato, sua aparente teatralidade é produzida na medida em que sua historicidade permanece dissimulada", e "inversamente, sua teatralidade ganha uma certa inevitabilidade, dada a impossibilidade de sua revelação histórica" (Butler, 2001:167). Foi com a intenção de valorizar as complexidades de um processo multifacetado, resgatando os momentos anteriores 
aos acontecimentos descritos, de modo a não simplificar a leitura das mobilizações, que, nas seções anteriores, recuperei a experiência de uma história que não pode ser reduzida apenas à eclosão visível dos conflitos.

A seqüência de acontecimentos que será evocada apresenta inúmeros atores em ação, em manifestação, ou mais precisamente, em confrontação com certas figuras, autoridades, instituições e agências públicas. São momentos de disputa, sendo que o que está em jogo é a definição dos próprios atores, suas posições e seus estatutos. Por isso, ao entrarem em cena, estes atores colocam em cheque muito mais do que apenas um episódio dramático. Não por acaso Foucault entende a cena, não como "um episódio teatral, mas um ritual, uma estratégia, uma batalha" (Foucault, 41:2006). Assim, a partir de um encadeamento de cenas estratégicas e conflitivas, circunscritas temporalmente entre 2005 e 2006, exponho a seguir um conjunto de confrontações, mobilizações e articulações políticas, tendo como referência a chegada da nova gestão municipal Serra (PSDB-PFL).

\subsubsection{Prelúdio}

A imagem era esta: o dia estava claro e no fundo, em meio às palmeiras, o Teatro Municipal apresentava seus traços tão característicos. Posando sorridente sobre o Viaduto do Chá estava Andrea Matarazzo, o mais novo subprefeito da Sé. Junto com a foto era possível ler na capa da Vejinha ${ }^{54}$ de Março: "Nova chance para o Centro. Dez idéias para que o coração da cidade recupere o antigo brilho e volte a ser um orgulho dos paulistanos". A matéria apresentava Andrea Matarazzo como um bem sucedido empresário, apaixonado por velocidade e motos caras. Havia sido embaixador do Brasil na Itália, ex-presidente da Cesp (Companhia Energética de São Paulo) e ex-secretário de Comunicação do governo Fernando Henrique Cardoso. A matéria apresentava também alguns dos problemas do centro de São Paulo e a maneira como o novo subprefeito da Sé pretendia resolvê-los. Iria dar fim aos calçadões, retirar os camelôs, os carroceiros e os mendigos, melhorar a segurança, instalar uma universidade na "cracolândia" e dar um "banho de limpeza" no Centro. Foi assim que a nova gestão municipal, José Serra (PSDB-PFL), apresentou publicamente suas propostas para o centro 55 .

\footnotetext{
54 "Vejinha" é o apelido dado à revista "Veja São Paulo", que publica informações só sobre o que se passa na cidade. Possui este apelido, pois acompanha a revista "Veja", que contêm informações de amplitude nacional. A revista aqui citada é do dia 16 de Março de 2005.

55 "Cracolândia" é um designador topográfico que se refere a uma região localizada no Bairro da Luz. A "causa de seu nome" residiria na presença do tráfico de drogas, no alto consumo de crack e na presença de prostitutas e
} 
Claro que estas notícias foram motivo de polêmica entre todo um conjunto heterogêneo de atores ${ }^{56}$. A crítica geral, como posteriormente se viu, era de que esta nova gestão teria assumido inicialmente uma postura muito "descolada" da dinâmica do Centro, pois este anunciado programa político de intervenção não tinha sequer estabelecido algum diálogo com os atores envolvidos com a realidade que se pretendia mudar. E foi no interior desta tensa atmosfera que se montou um seminário de políticas públicas para o Centro.

\subsubsection{Seminário de Políticas Públicas - 6/6/2005}

A proposta geral do seminário era "contribuir para um debate amplo sobre os projetos da prefeitura na região central, envolvendo representantes do governo, universidade, empresários, movimentos sociais, entidades de classe, entidades não governamentais e moradores". Pelo menos era isso que se podia ler, no programa distribuído logo na entrada do local. O espaço era um auditório cedido pelo Sindicato dos Engenheiros no Estado de São Paulo (SEESP), que se localizava no Centro, próximo à Câmara Municipal. Os principais organizadores do evento foram os Vereadores Chico Macena e Paulo Teixeira, ambos do PT, sendo que este último tinha sido, na gestão municipal anterior, secretário da Habitação. Contudo, não só estes atores políticos ajudaram na preparação do evento. Podia-se ler, no programa e em cartazes espalhados por todo auditório, o apoio do Centro de Convivência É de Lei, do Centro Gaspar Garcia de Direitos Humanos, da Universidade Mackenzie, da Faculdade de Arquitetura e Urbanismo da USP, do Instituto Polis, da Caixa Econômica Federal, do Governo Federal, entre outros. Pelo menos oficialmente, a prefeitura de São Paulo parecia não estar apoiando o evento, já que no ambiente havia uma total ausência de qualquer insígnia referente à mesma.

Como os responsáveis pela montagem do seminário possuíam uma filiação partidária antagônica à recente empossada gestão, todo evento já carregava, em si mesmo, uma certa tensão. Para participar do seminário, não era necessário pagar e nem se inscrever com antecedência. Havia na porta de entrada apenas um livro de assinaturas, no qual as pessoas se cadastravam. Parece que o seminário não tinha sido muito divulgado, a não ser entre as organizações mais influentes no Centro. Só fiquei sabendo de sua existência por ter

travestis. Apenas comento que, atualmente esta região, é alvo de fortes investimentos privados e públicos, sendo que esta designação pejorativa encaixa-se muito bem aos atuais propósitos de intervenção para a mudança da composição e freqüência social na região.

${ }^{56}$ Entre estes, podemos citar o Instituto PÓLIS, a OAF (Organização do Auxilia Fraterno), a Pastoral da Rua, o Centro Gaspar Garcia de Direitos Humanos e o Movimento Nacional dos Catadores de Materiais Recicláveis (MNCR). 
proximidade com a OAF e com o MNCR, organizações que foram convidadas. O evento estava marcado para se alongar durante todo o dia. Haveria quatro mesas de discussão. $\mathrm{Na}$ parte da manhã, a primeira mesa tinha o título de "Reabilitação do Centro de São Paulo" e a segunda "Habitação". Na parte da tarde, as mesas tinham os seguintes nomes: "Cracolândia e Inclusão Social" e "Trabalho e Desenvolvimento".

Às nove horas da manhã, o auditório já estava lotado. Tinha gente em pé no fundo e nos corredores do auditório, que literalmente era um espaço pequeno para um evento deste porte. Havia uma platéia com cerca de apenas 80 poltronas e um palco. Neste encontrava-se uma mesa com sete cadeiras para os expositores sentarem. Antes mesmo da primeira mesa se apresentar no palanque, todo o lugar já estava repleto de pessoas. O mais interessante era observar os tipos de personagens presentes na platéia. Muitas pessoas que ali estavam, visivelmente provinham de uma origem mais simples. Mesmo não sendo a totalidade, pois o público também se constituía por jornalistas, estudantes, técnicos e ativistas, era saliente o caráter popular da platéia. Pela postura e traços, expressões e vestimentas, a distinção social colocava-se de maneira marcante. Reconheci algumas das pessoas lá presentes. Havia pessoas ligadas aos movimentos de luta por moradia, às cooperativas de catadores (com camisas do MNCR), além de encontrar Sebastião e Anderson, figuras que estavam encabeçando o recém nascido Movimento Nacional de Luta e Defesa dos Direitos da População em Situação de Rua. Trajando roupas simples, algumas até sujas, homens e mulheres, algumas com bebês de colo, crianças e pessoas com idade avançada, ressaltavam o caráter popular presente na platéia.

O cenário já estava assim, tão cedo, montado e repleto de personagens ansiosos, e não à toa. Sem sombra de dúvida, a mesa mais esperada era a primeira, justamente aquela que abriria os trabalhos. O que era de fundamental importância nesta mesa era a participação tão esperada de Andrea Matarazzo, figura pública esta que desde sua assunção de posse na Subprefeitura da Sé, não havia estabelecido diálogo com as entidades e outros atores sociais vinculados aos setores de baixa renda do Centro. Nesta mesma mesa também se sentaram outras figuras de proeminência política, como por exemplo: Raquel Rolnik, Secretária Nacional de Programas Urbanos do Ministério das Cidades da gestão do governo federal (petista), Nadia Somekh, Diretora da Faculdade de Arquitetura e Urbanismo da Universidade Mackenzie e ex-presidente da Empresa Municipal de Urbanização (EMURB) da gestão municipal anterior (PT, 2001-2004), e Regina Meyer, professora da FAU e ex-assessora da Associação Viva o Centro. Contudo, logo no começo, quando Andrea Matarazzo subiu no 
palco, iniciou-se na platéia toda uma movimentação e ficou muito claro que a personagem alvo do público era o subprefeito mesmo.

As falas iniciais dos palestrantes foram relativamente tranqüilas e tinham em comum o fato de apontarem para a necessidade de se estabelecer instâncias de diálogo entre a heterogeneidade dos grupos sociais existentes no Centro e o projeto político de "requalificação", comandado pela nova gestão municipal. Quando o subprefeito tomou o microfone, a movimentação do público foi geral. A platéia claramente colocava-se em posição de enfrentamento para com Matarazzo e este parecia estar ficando nervoso.

"Existe a percepção de que o Centro é um lugar inseguro, e é contra esta percepção que devemos lutar". E para tal luta se concretizar, uma série de intervenções seria levada a cabo. Em verdade o subprefeito reafirmou, de certo modo, tudo aquilo que já havia exposto três meses atrás, na entrevista da Vejinha. Contudo, durante seu discurso muitas afirmações foram mudando de tom, e abrandando, de acordo com as reações do público. Agora afirmava, também, que a diversidade social do Centro deveria ser mantida, que era necessário "cuidar das pessoas em situação de rua", criar mais cooperativas para "estimular a reciclagem" e, que para "evitar a circulação de carroças no Centro", era necessário uma vigorosa "política de transporte de resíduos sólidos". Ocorreram muitas vaias, e insultos como "mentiroso" e "higienista" foram lançados da platéia em direção ao palestrante. À medida que os momentos se sucediam, a platéia gradativamente deixava de ser simplesmente um espectador para tornar-se ator envolvido no drama. A movimentação da platéia, as reações do subprefeito e suas respostas iam inflando os ânimos já acirrados. A cena ia, então, adquirindo dinâmica e potência. O teatro de luta ganhava força.

Assim, os antes espectadores, tornaram-se claramente participantes do jogo e passaram a reivindicar suas próprias posições e visões. O público ansiosamente queria ter voz, queria ter palavra e ser ouvido pelas autoridades. Devido à falação e à vaia generalizada, tornou-se impossível impedir que Matarazzo falasse. Foi aberto então o microfone para a platéia, que questionou muitas das atitudes tomadas pela nova gestão. A maneira como foi efetuada a expulsão dos meninos e meninas de rua e de "usuários de crack", que circulavam no entorno da região da Luz, ação esta intitulada pela prefeitura como "operação limpa", suscitou fortes críticas. Reclamou-se da diminuição radical do número de autorizações para os ambulantes venderem na rua, fato que gerou, semanas antes, manifestações de rua e até mesmo conflitos entre os camelôs organizados e a tropa de choque da polícia militar. Um integrante do Movimento de Moradia de Centro (MMC) tomou a palavra e afirmou ser um absurdo a prefeitura não ter nenhum programa de moradia popular no Centro, já que esta é a região da 
cidade com o maior número de imóveis vazios. Anderson, que se apresentou como representante do Fórum da População em Situação de Rua ${ }^{57}$, afirmou que o subprefeito havia se negado a recebê-lo por três vezes consecutivas desde que assumiu o cargo. Reclamou também que o subprefeito não poderia sair "chamando na revista, morador de rua de mendigo, tem uma diferença aí!” Outro motivo de protesto foi o cercamento da Praça da República, principalmente pelo fato da prefeitura não ter explicado publicamente o motivo que a levou a esta atitude. Chegou-se a afirmar que com as grades da República a prefeitura queria era "proibir os pobres de andarem pela cidade".

Uma pessoa com a camisa do Movimento Nacional dos Catadores de Materiais Recicláveis (MNCR), ao tomar o microfone, falou que a prefeitura estava querendo "acabar com o trabalho dos catadores no centro da cidade". Pois, mesmo querendo instalar novas cooperativas, não estava interessada em abrir diálogo com aquelas que já existiam. A prefeitura "mais atrapalha do que ajuda na catação". Em verdade em abril do mesmo ano, um vereador do PFL havia apresentado um projeto de lei (Lei 171) que foi extremamente rejeitado pelas organizações de catadores do centro de São Paulo. Este projeto propunha, entre outras coisas, o cadastramento obrigatório de todos os catadores que utilizam carroças, a obrigatoriedade de cursos de higiene, a necessária padronização de todas as carroças no prazo máximo de um ano, sendo que estas deveriam contemplar espaço para a propaganda e publicidade. Por fim, tal padronização seria patrocinada pela iniciativa privada ou facilitada através de financiamento de crédito. As críticas a esta lei eram várias e a única pessoa que poderia vetar este projeto era o novo prefeito José Serra. O catador que protestava ao microfone contra a ação da nova prefeitura afirmava que esta, até agora, tinha se silenciado a respeito do fato. Asseverava, também, que muitos dos catadores estavam apreensivos devido ao emudecimento da prefeitura em relação ao projeto de lei, que atrapalharia em muito suas vidas. Por fim, anunciou que no dia seguinte haveria uma manifestação pública contra o dito projeto lei.

Muitas palavras foram proferidas e as críticas voltavam-se, de maneira geral, para a incompatibilidade entre o projeto de intervenção no Centro e o que se passava por lá. Havia aquela ebulição de vozes, muitas vezes simultâneas, já que enquanto um falava ao microfone outros, freqüentemente, o apoiavam em forma de afirmações em voz alta, "é, você só quer expulsar os pobres", "quer por os pobres para fora". Parecia haver uma inabilidade por parte

\footnotetext{
${ }^{57}$ Como já comentado, este fórum foi justamente a instância coletiva de discussão e formação que possibilitou a organização e o lançamento do Movimento Nacional de Luta e Defesa pelos Direitos da População de Rua (MNPR). Mesmo com a construção deste movimento social, o Fórum continuou existindo por alguns meses.
} 
do subprefeito para responder e reagir àquela avalanche de críticas. O choque proporcionado pelas reclamações deu a impressão geral de que o poder público nunca tinha ouvido tais vozes, e que havia uma grande distância entre o projeto político de transformação do Centro e a realidade que este buscava intervir. As reclamações acompanharam aquilo que Padre Júlio Lancelotti, Vigário do Povo da Rua, posteriormente em outra mesa, chamou de "descolamento do poder público".

Provavelmente um dos momentos mais dramáticos de todo evento, em que o agonismo pareceu arrebatar todos aqueles envolvidos no jogo absorvente, foi quando, acuado e tentando responder às críticas, o subprefeito disse: “Apenas tapei buracos, reparei lâmpadas, consertei placas, restaurei calçadas e arrumei semáforos. Só fiz o que era para ser feito. Não tive nada a ver com o resto". Neste exato instante, uma senhora grande e negra levantou-se com uma criança no colo e em alta voz, vociferou: "Não tem nenhum resto aqui, não. Se o senhor acha que nós somos resto, o senhor está muito enganado. Nós somos cidadãos e temos direito de morar e viver na cidade como todo mundo". Neste momento, a platéia foi abaixo. Vaias e aplausos, muitas pessoas falando alto e, ao mesmo tempo, vozes de apoio à mulher e, em meio a todo alvoroço, o subprefeito tentando se desculpar pelo mal entendido.

A seqüência disso foi a finalização da fala de Matarazzo ou, mais precisamente, a incapacidade deste se pronunciar. A palavra foi passada para outros palestrantes e o restante dos comentários da mesa foi na direção de afirmar que tudo aquilo que estava se passando ali, demonstrava a extrema necessidade da criação de espaços de diálogo entre o poder público e os grupos populares do Centro. Particularmente Raquel Rolnik e Nadia Somekh, ambas ligadas ao PT, principal partido de oposição à atual prefeitura, foram duas personagens que enfatizaram reiteradamente esta questão e criticaram também a atuação da nova gestão.

Após o término da mesa, Matarazzo retirou-se acompanhado por seguranças e seguido também por várias pessoas que estavam na platéia e queriam lhe falar. O restante do seminário se deu num clima um pouco mais ameno do que o apresentado na mesa de abertura. O público foi diminuindo gradativamente, com a saída do subprefeito. Só depois do almoço é que a tensão gerada por um atrito entre o Padre Júlio Lancelotti e Floriano Pesaro, Secretário Municipal de Assistência e Desenvolvimento Social, foi quebrar a calma que se apossou do evento após a saída do subprefeito. O novo secretário, ao discorrer sobre a importância de não se dar esmolas para as pessoas que se encontram em situação de rua, pareceu incitar a ira do Padre Júlio. Este afirmou que "o dar é um atributo reservado ao fórum íntimo de cada pessoa, não cabendo à prefeitura decidir tal coisa". E em tom agressivo, disse "quem dá esmola para a sociedade é o Estado, que diminui cada vez mais os recursos destinados à assistência social”. 
O que se viu em seguida foi uma seqüência de ataques, que iam e voltavam. Mesmo com o auditório não estando mais tão cheio, o conflito gerou comoção da platéia, fazendo com que muitas vezes as palavras proferidas pelo Padre fossem aplaudidas.

Pode-se falar que este evento foi o primeiro encontro público da nova gestão municipal com uma ampla coletividade de personagens atuantes no Centro e ligados aos segmentos populares. Nele foi possível notar o quase total desconhecimento, ou desinteresse, por parte da nova gestão, da complexidade de boa parte das questões envolvidas e da vida social existente nesta região. O ponto crucial do evento foi a aparição da figura pública do subprefeito. Este, talvez, por ser a autoridade máxima na região, manifestada através da imprensa, foi o grande alvo da platéia. A visão desta figura pública permitiu que a responsabilidade dos anseios, das pessoas e grupos que ali se encontravam, se canalizasse totalmente em sua direção. A expressão disto foi a avalanche de críticas, reivindicações e até insultos que o público lançou para Matarazzo, tornando-o o grande antagonista daquele evento. De herói, o nosso subprefeito sorridente e vitorioso parecia agora se ter metamorfoseado em vilão. Ou pelo menos era isso que ele parecia encarnar para os praticantes dos espaços do Centro, que foram ali reivindicar suas visões e versões sobre a vida nesta região.

\subsubsection{Ato contra a lei $-7 / 6 / 2005$}

A concentração estava marcada para as $10 \mathrm{~h}$, em frente à Câmara Municipal dos Vereadores. Aos poucos, se via chegar mais e mais carroças e carrinhos ${ }^{58}$. Pareciam vir de tudo que é lugar e, apesar de terem um determinado padrão comum em sua estrutura, os diferentes materiais utilizados em suas construção, as diversas cores, as placas e os enfeites variados davam um certo espírito alegórico e carnavalesco àquele conjunto de artefatos móveis. Às $11 \mathrm{~h}$, a animação já estava bem elevada. As carroças iam se concentrando cada vez mais e seu número já ultrapassava os quarenta. A presença de um carro de som, que continuamente tocava algumas músicas de ritmo popular, como xote, vanerão e marchinhas, e

\footnotetext{
${ }^{58}$ Tanto carrinhos quanto carroças referem-se aos veículos de trabalho utilizados pelos catadores de São Paulo. Em quase toda a cidade, com exceção de alguns poucos espaços urbanos localizados na periferia, estes artefatos são movidos à tração humana e suportam o peso da carga apenas em um eixo com duas rodas. Algumas carroças, devido à sua estrutura e ao material utilizado, permitem carregar cerca de $800 \mathrm{~kg}$. O carrinho, principal instrumento de trabalho para a grande maioria dos catadores da cidade, é, ao mesmo tempo, vetor de deslocamento, transporte para o material coletado e 'casa ambulante' para aqueles que vivem nas ruas. Os nomes deste artefato variam de acordo com as cidades e as regiões do país, contudo, pelo fato de aqui em São Paulo, carrinhos e carroças serem usados, ambos quase como sinônimos, tratarei aqui os dois termos como intercambiáveis.
} 
que falavam sobre os catadores, imprimia sonoridade a toda aquela efervescência. As pessoas cantavam e dançavam, outras se cumprimentavam e conversavam. Muitas bandeiras e placas coloridas despontavam nas mãos dos manifestantes. Havia também uma composição muito própria, no que se refere ao figurino de alguns atores. Tal fato era notado através das camisas e macacões coloridos, com o nome das respectivas cooperativas, que grupos de pessoas trajavam. A maneira como aquelas vestes ali se realizavam era nitidamente outra da cotidiana. O uniforme de trabalho diário ali, naquele momento, se metamorfoseava em outra coisa. Ao ser incorporado naquele contexto vivo e festivo, o uniforme habitual transformava-se em símbolo de orgulho e altivez. Toda aquela gente junta e animada, como um quadro composto por coloridos emblemas em movimento, manifestava uma afirmação positiva por estar ali. A inquietação e a empolgação eram expressões marcantes. Sem sombra de dúvida, este não era um momento qualquer.

Definitivamente, para aquelas pessoas este era um dia muito especial. Ele fora definido três anos atrás, em 2001, na "Primeira Marcha da População de Rua e dos Catadores de Materiais Recicláveis". Pelo fato do final da marcha ter se realizado no dia 7 de junho, este foi escolhido como o dia de mobilização nacional do movimento. Foi acordado, desde então, que em todo país os catadores organizados praticariam manifestações públicas, como forma de luta pelos desafios locais (MNCR, 2005).

E o desafio que os catadores de São Paulo então enfrentavam era o já citado projeto de Lei 171. As críticas à lei eram várias e foram formalizadas em um documento escrito pelo próprio MNCR. Neste documento, dizia-se que antes de se tomar qualquer atitude política, seria necessário haver uma discussão do poder público com a categoria de trabalhadores que são objeto desta lei. Afirmava-se, também, que o credenciamento proposto e as regras deles decorrentes fortaleceriam apenas os atravessadores, já que os catadores não possuem condição de honrar com as despesas de novos carrinhos padronizados. Outra crítica foi de que a lei proposta teria repercussões extremamente negativas e potencialmente excludentes para os catadores individuais e não organizados, e que às vezes nem possuem carrinhos para trabalhar. Este perfil de catador, marcado pela rua, que muitas vezes se encontra submetido aos atravessadores e que historicamente utiliza o centro da cidade como espaço de trabalho, seria o mais atingido com a implementação desta lei. Por último, o MNCR repudiava terminantemente a obrigatoriedade, proposta pelo projeto, da publicidade veiculada nos carrinhos dos catadores.

Tal projeto de lei não havia sido feito pela nova gestão municipal, contudo era em direção a esta que os manifestantes teriam de se voltar, pois este só poderia ser vetado pela 
assinatura do prefeito José Serra. Como a prefeitura, mesmo recebendo diversas cartas, mensagens e dizeres contrários à lei, havia silenciado em relação ao caso, foi resolvido que em São Paulo o tema do dia de mobilização nacional dos catadores seria a luta pelo veto deste projeto de lei. $\mathrm{O}$ ato público foi organizado visando fundamentalmente chamar a atenção do Estado para as questões que este projeto de lei colocava em jogo. Por isso mesmo, a mobilização iniciar-se-ia na mesma Câmara onde a lei fora proposta e terminaria em frente à sede da prefeitura, instituição que poderia dar fim ao indesejado projeto. A manifestação que agora se via, tinha sido organizada pelo MNCR, sendo que este recebeu o apoio de outras organizações atuantes no centro, como o Fórum Lixo \& Cidadania, a OAF e a Rede Rua. Estavam lá presentes outros atores sociais, representantes de diversas cooperativas de catadores, do Fórum das Organizações que trabalham com a População em Situação de Rua e do Fórum da População em Situação de Rua de São Paulo.

Ao colocar-se em movimento, aquele aglomerado de pessoas foi se transformando paulatinamente em uma grande e chamativa comitiva. A rua agora se tornava cenário de um teatro em movimento. Na frente ia o carro de som, do sindicato dos comerciários do Estado de São Paulo, puxando o hino nacional dos catadores de materiais recicláveis. Este hino pouco tinha de imponência e grandiosidade, pois por ser em ritmo de xote, transmitia muito mais animação do que reverência. No entorno do carro muitas pessoas, caminhando a pé, levantando placas e bandeiras em mãos, cantavam e dançavam a música. Contudo, de toda aquela parafernália o mais impressionante, o que mais se destacava, aquilo que era mais espetacular era o longuíssimo cortejo. Já se somavam então cerca de sessenta carroças, que em fila atrás do carro de som assemelhavam-se, e em muito, a um verdadeiro desfile em pleno centro de São Paulo.

E o desfile era grande, tomava toda extensão do viaduto da Nove de Julho. Enquanto na frente, o carro de som já ia saindo do viaduto e tornando à direita, a cauda alongada do enorme cortejo ainda sequer tinha adentrado completamente no trecho. Além de tomar metade do amplo viaduto, aquele teatro de rua, seguido por inúmeras carroças e carrinhos, o fazia na direção contrária dos carros que vagarosamente cruzavam ao lado do espetáculo. O trajeto da manifestação na direção da prefeitura, na contra mão da avenida, em alto som e em alta voz. Todo aquele trabalho de figuração rompia com o sentido cotidiano da rua, deslocava-o, estranhava-o. Aquela comprida fila de artefatos em movimento, puxados por homens e mulheres, era algo que chamava a atenção, atraía os olhares do público. Naquele momento, regras (como as de trânsito) foram temporariamente suspensas, a rua deixava de ser o espaço 
do ordinário para metamorfosear-se em espaço do extraordinário. A rua, agora, transformavase em cena de uma enunciação performática.

Chocava os transeuntes a quantidade de carroças seguindo em linha, muitas delas decoradas com bandeiras e cartazes com dizeres de contestação e enfrentamento. Muitos destes dizeres estavam acompanhados com uma referência à cidade, região, bairro, cooperativa ou instituição de origem e isso permitia também notar a grande heterogeneidade dos lugares, referências e personagens ali presentes. As frases e palavras pronunciadas e anunciadas ao público eram diversas e possuíam um caráter eminentemente político. Os gritos de guerra, as palavras lançadas ao espaço público da rua eram palavras de combate: "Catador organizado jamais será pisado". Nas placas que os manifestantes carregavam, exprimiam-se conflitos e contradições que, antes latentes, eram agora manifestos: "Mileano limpando a cidade. Cadê o pagamento? Catador Boracéia". "Catador: um profissional que limpa a cidade, ajuda a natureza e a prefeitura retirando toneladas de resíduos por dia. Coopamare". "Prefeito, reconheça nossa categoria profissional. Cooperativa da Granja Julieta”.

Os anseios e dificuldades enfrentadas diariamente podiam agora, mesmo que momentaneamente, tornarem-se públicas: "Estão querendo tirar o meu carrinho da rua". "Queremos ter o direito de continuar a limpar a nossa cidade. Sim ao veto". "Deixe-nos Trabalhar". "Queremos continuar nosso trabalho em paz. Cooperativa da Granja Viana". “Todos têm direito a um trabalho mesmo que seja puxando carroça na rua. Casa de Oração". Reivindicações são expressas. "Justiça para os carroceiros. MNCR". "Trabalho, moradia, dignidade e respeito". "Queremos organização, não exclusão. Catador Boracéia". Sonhos e projetos são anunciados: "Catadores por um mundo melhor. Avaré". Neste momento de estranhamento e suspensão dos sentidos ordinários, até mesmo nomes consagrados e respeitados, como o do antagonista, poderiam virar motivo de brincadeira: "Estão serrando nossas vidas", e assim, a própria imagem do poder era satirizada.

Nas placas, através do traço, da escrita e do desenho, expunham-se publicamente potenciais conflitos entre visões de mundo, representações antagônicas e oposições prenhes de dramas sociais: "Coleta seletiva sem catador é lixo". "Políticas públicas, queremos ter voz. Coopamare". "Senhor prefeito, não queremos esmola, queremos trabalho. Povo da rua". Até mesmo classificações tão comuns são questionadas: "Lixo não é lixo". Afirmações positivas são feitas: "Catador é profissão. MNCR".

Quando a comitiva, depois de atravessar em desfile a Praça Ramos e o Viaduto do Chá, chegou à frente à sede da prefeitura, qual foi a decepção em saber que o prefeito, alvo de todo aquele alvoroço coletivo, não estava presente. Aquele mundaréu de carroças, que havia 
fechado o trânsito do centro da cidade para chegar até ali, agora mal cabia em frente à prefeitura junto com os manifestantes. Estes diziam que o prefeito, sabendo com antecedência da mobilização que buscava interpelá-lo, havia estrategicamente evitado dar as caras por ali. Mesmo assim, o drama persistia. No carro de som, continuamente se afirmava a causa do ato público: "A prefeitura quer atrapalhar o nosso trabalho, mas não vamos deixar isso acontecer". Pelas caixas de som, foi afirmado que não se ia sair da frente da prefeitura enquanto esta não se comprometesse em vetar o projeto de lei. A pressão foi aumentando e os gritos de guerra não pararam: "Catador organizado, jamais será pisado". Em alguns momentos, lá em cima do caminhão de som, gritavam: "Recicla ou não recicla?" E lá embaixo, os manifestantes respondiam: "Recicla!”.

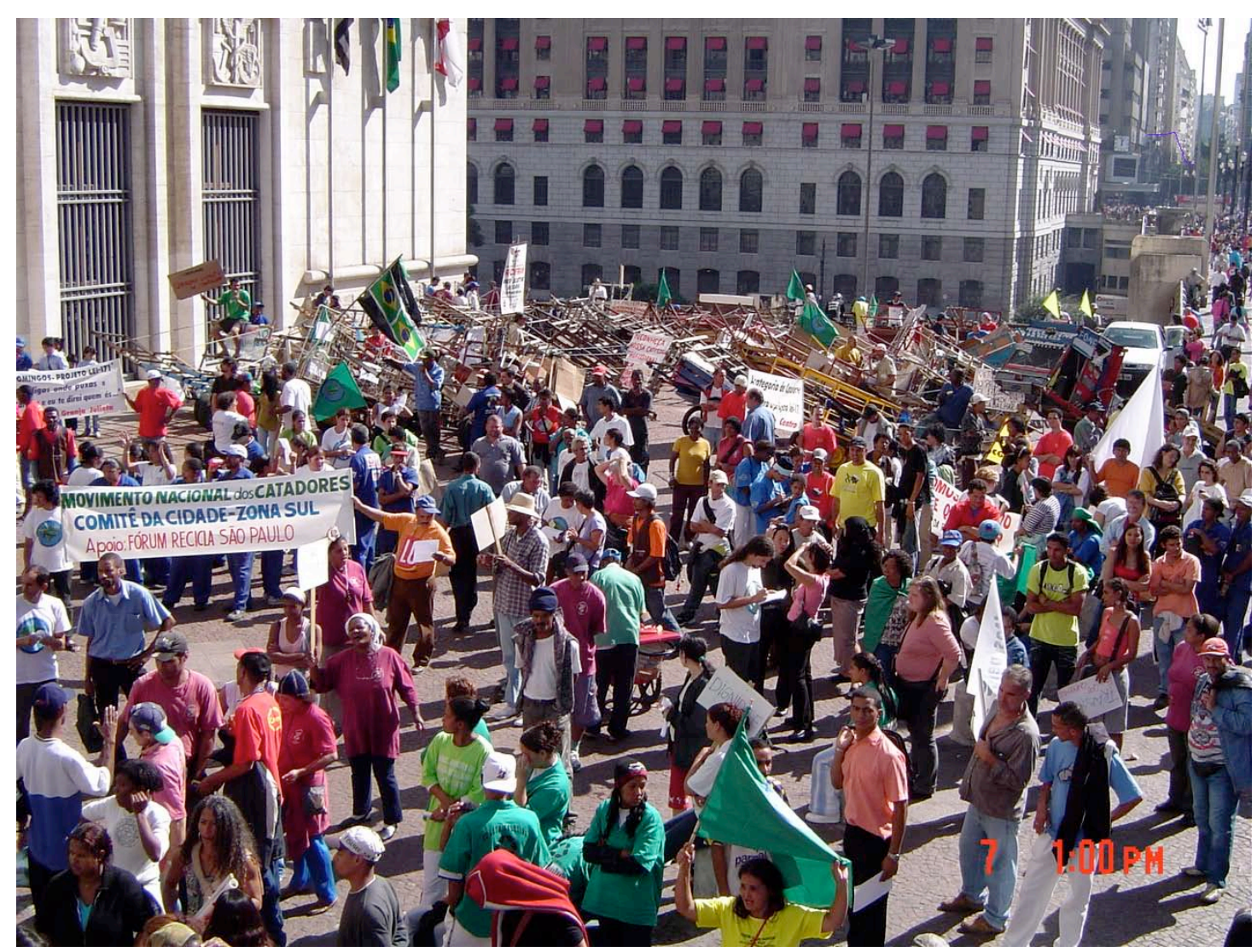

Momento de pressão na Praça Patriarca em frente à Prefeitura de São Paulo.

Fonte: arquivo do Movimento Nacional dos Catadores de Materiais Recicláveis

Em frente à entrada da prefeitura, Sebastião Nicomendes, um dos integrantes do recém criado MNPR, estava todo paramentado e levantava em haste aquilo que parecia ser um emblema, uma espécie de símbolo da população de rua. Enrolado em um cobertor escuro e vestindo havaianas, Tião, como era também conhecido, segurava e balançava um longo 
pedaço de pau com algumas coisas amarradas em sua extremidade superior: um saco plástico negro destes de lixo doméstico, uma garrafa de refrigerante pet vazia e três bandeirinhas do Brasil. Com esta simples composição, Sebastião parecia querer expressar uma certa especificidade da rua. Ao conversar com ele, me disse: "essa é a bandeira da rua que eu fiz para hoje".

Já eram cerca de $14 \mathrm{~h}$ quando, depois de muita pressão, assessores do prefeito aceitaram dialogar com uma comissão formada por catadores de materiais recicláveis e alguns técnicos de apoio ${ }^{59}$. Depois que a comissão de delegados entrou na prefeitura, as pessoas que ali estavam ficaram mais acomodadas, mas não por isso menos tensas. A manifestação só foi se dispersar uma hora e meia depois, às $15 \mathrm{~h} 30$, quando os assessores deram certeza de que o prefeito receberia em mãos o documento entregue pelo MNCR e daria fim ao silêncio em relação à lei.. Cerca de dez dias depois do evento, foi anunciado o veto do projeto de lei 171 pelo Prefeito José Serra.

\subsubsection{Ato contra o Massacre da População de Rua - 19/8/2005}

Fazia um ano do "massacre dos moradores de rua". O acontecimento tinha obtido grande repercussão na época, chegando até a sair em periódicos internacionais. Um caso um tanto sinistro no qual, em apenas três dias consecutivos (19, 20 e 21 de agosto de 2004), 15 pessoas que dormiam nas ruas foram alvo de fortes golpes e pancadas na cabeça, sendo que os culpados nunca foram encontrados. $\mathrm{O}$ atentado tinha matado sete pessoas. Dos oito sobreviventes, sabe-se atualmente apenas do paradeiro de dois. O que tornou o tal episódio mais problemático ainda, é que os principais suspeitos da matança são policias militares e, como se isso não fosse o bastante, existe a forte hipótese de que algumas vítimas que sobreviveram ao atentado e outras testemunhas do crime tenham sido assassinadas também por policiais (Estado de São Paulo, 19/09/2004, Folha de São Paulo, 20/08/2004). Foi com o intuito de chamar a atenção das autoridades e da opinião pública, para o caso de impunidade

\footnotetext{
59 Algumas vezes, quando da negociação com instâncias do poder público ou privado, catadores são acompanhados por técnicos de entidades e ONGs que os apóiam. Essa prática, com o recente fortalecimento do movimento, deixou de ser consenso dentro do MNCR e, algumas vezes, torna-se motivo de muitos atritos entre os catadores mais politizados e os técnicos "apoiadores". As divergências giram, basicamente, em torno do fato dos primeiros desgostarem da demasiada atuação e interferência dos segundos no processo de organização e negociação, já que a proposta do MNCR é fundada justamente na autogestão e organização dos próprios catadores. Enquanto, por outro lado, os técnicos afirmam serem necessários, pois, no diálogo direto com instâncias superiores (grandes empresas e órgãos públicos), facilmente os catadores são "enganados" e "iludidos" com promessas. Independentemente, se os catadores são iludidos ou não, é importante ressaltar que tal controvérsia demonstra um debate de fundo que talvez tenha como querela o grau da "tutelagem" que as organizações apoiadoras possuem sobre o MNCR.
} 
ocorrido e para a situação das pessoas que ainda se encontram vivendo nas ruas de São Paulo, que o protesto "contra o massacre da população de rua" fora organizado pela Pastoral do Povo da Rua e outras organizações, como o recém nascido Movimento Nacional de defesa e luta pelos direitos da População em Situação de Rua.

O drama se daria, não por acaso, num palco, num espaço-tempo privilegiado. Meiodia, numa plena sexta-feira, em frente à escadaria da Catedral da Sé, marco zero da cidade e ambiente carregado de simbolismo. As sextas-feiras são em geral dias mais movimentados no Centro e no horário do almoço, esta vida ganha mais dinâmica ainda. Contudo, naquele dia o local parecia possuir uma ebulição mais intensa do que o normal. Justamente em frente à escadaria da Sé, havia um palanque onde se realizariam algumas apresentações musicais. O palco montado não fazia parte da manifestação planejada, e por deixar pouco espaço para os manifestantes se alojarem nas escadas, aquelas estruturas de metal e toda gente ali amontoada aumentava mais ainda a impressão de bagunça e confusão, aspectos estes tão ligados à experiência dos espaços públicos do centro de São Paulo.

Naquele apertado espaço, todos foram gradativamente se amontoando e se ajeitando, até que às $12 \mathrm{~h} 20$ já havia umas 500 pessoas, juntamente com toda a parafernália alegórica e festiva de bandeiras, percussões, placas, apitos, faixas, cartazes e bandeirinhas. O que era notável em toda aquela movimentação era a multiplicidade dos personagens envolvidos. Participavam deste drama inúmeros atores sociais: religiosos vestidos com seus respectivos figurinos, políticos, algumas figuras sujas e alcoolizadas, usuários de albergues, catadores com carroças, representantes e lideranças de sindicatos, movimentos e organizações sociais, jornalistas e fotógrafos. Muitos vendedores ambulantes também estavam observando aquele acontecimento que, ali mesmo, no seu espaço diário de trabalho, transformava-se em um teatro. Bem acima de toda aquela efervescência, ebulição e confusão coletiva, um helicóptero de imprensa voava e registrando à distância o evento.

No centro da escadaria da Catedral da Sé, havia uma cruz de madeira e papelão com os nomes dos mortos escritos e um cobertor pendurado em sua haste superior, como se fosse um cachecol. No chão e no entorno da cruz havia caixas de papelão, latas e latinhas de refrigerante vazias, pilhas de papel e garrafas plásticas, todo um conjunto de objetos que diziam respeito ao chamado lixo urbano e ao material de trabalho de grande número de pessoas que vivem nas ruas de São Paulo. Desde o massacre do ano passado, até então, todos os dias dezenove algum tipo de cerimônia era feita ali na frente da escadaria da Sé, com 
aquela mesma cruz, para lembrar o ocorrido e a impunidade dos culpados ${ }^{60}$. Naquele dia, passado um ano da matança, o caso era relembrado de maneira espetacular.

Com o microfone na mão, Padre Júlio Lancelotti comandava o trabalho coletivo de figuração. Ao seu lado, encontravam-se o Arcebispo de São Paulo Dom Cláudio Hummes e representantes de várias denominações religiosas, como Pastora Mabel, da Igreja Batista, uma outra Pastora da Igreja Metodista, um Babalorixá ${ }^{61}$. Sendo que posteriormente, no transcorrer do ato, um rabino e uma monja apresentaram-se também publicamente. Todos sacerdotes tiveram acesso ao microfone. Com exceção do Padre Júlio, que sempre buscava politizar mais as questões, a paz era o mote dos discursos dos religiosos e todos, cada um ao seu modo, apontaram para a importância do poder público "dar a devida atenção ao Povo da Rua". Repetidamente, anunciava-se ao microfone que os sacerdotes ali presentes representavam “todas as igrejas, unidas pela paz".

Os escritos hasteados pelos manifestantes eram muitos. Havia grandes bandeiras brancas, as coloridas do MNCR e outras com a escrita "Peace", que despontavam marcadamente na multidão. Outros escritos menores em cartazes diziam: "Dignidade Para o Povo da Rua. Casa de Oração", "Um ano, onde estão os culpados?", "Somos um povo que quer viver. Pastoral da Rua, Arquidiocese de São Paulo", "Deus está conosco", "Não vamos nos calar", "Onde está a justiça?", "Queremos solução", "Somos seres humanos". Nas carroças dos catadores enfeitadas ali presentes, também era possível ler: "Não somos marginais, somos seres humanos, queremos respeito", "O Povo da Rua não é lixo, é gente, é cidadão, não pode ser tratado como lixo", "Queremos trabalhar", "Queremos continuar no centro", "Matarazzo quer varrer o povo da rua do centro. Coopamare".

Nos últimos meses, o subprefeito da Sé e as políticas de intervenção no Centro tinham sido alvo de muitas críticas, e tais críticas chegaram até mesmo a aparecer na imprensa. Provavelmente um dos motivos pelo qual o evento ganhou tamanha força e visibilidade foi devido à insatisfação de alguns segmentos da região para com as atitudes tomadas pelo poder público. Particularmente o MMC (Movimento de Moradia do Centro) e o MNCR

\footnotetext{
${ }^{60} \mathrm{E}$ isso era afirmado constantemente pelo Padre Júlio Lancelotti no microfone. Em verdade eu mesmo cheguei a presenciar dois destes eventos menores que foram feitos à noite, quando a Praça da Sé estava mais tranqüila, e possuíam um forte caráter religioso. Aquela cruz, com o nome dos mortos, parecia ter se tornado uma espécie de símbolo para os grupos envolvidos na articulação política do pós-massacre. A cruz estava presente nos dois cerimoniais menores que ali assisti nos dias 19, e foi também levada e exposta no II Festival Lixo e Cidadania em Belo Horizonte, Minas Gerais, encontro este em que instituições, movimentos sociais e representantes do poder público discutiram as condições e possibilidades da população de rua e dos catadores de materiais recicláveis do Brasil.

${ }^{61}$ No caso deste Babalorixá, Pai Antônio, o interessante é que quando tomou o microfone deu o depoimento de ter sido menor de rua por dois anos em sua infância, sendo que quem o salvou da rua foram os Orixás.
} 
participavam ativamente do protesto. Alguns dias antes do evento, 70 famílias sem-teto tinham sido expulsas de uma ocupação feita pelo MMC. Naquele dia, integrantes do movimento estavam lá reclamando do ocorrido e pedindo apoio público para sua causa. No caso dos catadores, as críticas eram várias.

Fazia mais de quatro meses que a Coopamare, que se localizava embaixo de um viaduto, estava sendo ameaçada de despejo pela prefeitura. $\mathrm{O}$ espaço, que fora cedido há mais de doze anos pela gestão municipal de Luiza Erundina (PT, 1989-1992), deveria ser desocupado segundo a nova prefeitura, pois constituía local de alto risco. O problema maior é que não se propunha nenhum tipo de negociação ou barganha por outro espaço. A luta pela permanência da Coopamare no local era de extrema importância para o movimento dos catadores e para as organizações que trabalham com estas pessoas. Por ela ter sido a primeira cooperativa de catadores de materiais recicláveis do Brasil, e por encontrar-se na maior capital do país, constituía-se como uma referência simbólica e estratégica de resistência, não podia ser fechada. Outra questão mais emergencial para os catadores era o fato de que, apenas três dias antes da manifestação, a prefeitura tinha apreendido cerca de uma dezena de carroças. Este fato gerou um temor generalizado entre os catadores de que agora se viam ameaçados de perder seus instrumentos de trabalho.

Neste mesmo período, também foram fechados pela prefeitura vários depósitos e ferros-velhos clandestinos localizados no Centro, tirando potencialmente a alternativa de trabalho dos catadores avulsos e não organizados. Estas ações da prefeitura foram interpretadas e anunciadas na manifestação como o "massacre dos catadores". Afirmava-se que no caso do "massacre da população de rua", apesar de toda suspeita, não se sabia claramente quem eram os culpados, e agora no "massacre dos catadores" sabia-se muito bem quem era o culpado: a própria prefeitura. No microfone, falava-se: "Não vamos permitir o segundo massacre, pois agora sabemos quem são os responsáveis. É o poder público!”.

Padre Júlio entrega, então, um documento escrito pelo MNCR ao Senador Eduardo Suplicy (PT). Este se compromete a reunir-se com Andrea Matarazzo e Floriano Pesaro, para conversar sobre as reivindicações dos catadores. O interessante é que Pesaro, atual Secretário da Assistência e do Desenvolvimento Social, também se encontrava ali, só que diferente do senador, não conseguiu ter acesso ao microfone. Em verdade quis falar, mas não conseguiu, pois foi impedido pelo Padre Julio, que afirmou que aquele momento da manifestação era um ato ecumênico e somente depois é que o ato se tornaria político. Aí, então, poderia pronunciar-se. 
Depois de muitos cantos e orações, faz-se uma reza do pai-nosso. Neste exato momento três moradores de rua, que cercavam e não paravam de interpelar o senador, disputam entre si o direito de rezar segurando a mão da autoridade. Enquanto o padre no microfone reza, a imagem do Senador Suplicy, de olhos fechados e de mãos dadas com dois aparentes e "típicos moradores de rua", é filmada pela câmera da imprensa, que não poderia deixar de perder um registro daquele.

A multidão coloca-se, então, em movimento. O carro de som na frente e os manifestantes no entorno e atrás. O ajuntamento ao deslocar-se parecia novamente um desfile, uma procissão, com músicas, cruz, bandeiras e carroças. Vinte e cinco carrinhos davam um destaque à mobilização e um aspecto de cauda e cortejo. Canta-se o hino dos catadores de materiais recicláveis e outras músicas com referências religiosas e espirituais que falam do Povo da Rua. Frases são afirmadas: "Não vamos permitir o segundo massacre”, "os catadores não sujam a cidade, eles a limpam”, "o Povo da Rua vai catar o lixo e a corrupção que está sujando a política”. Como em jogos de guerra, também nos jogos de linguagem coisas são projetadas em direção a um outro interlocutor. Assim, palavras de combate e diálogo foram lançadas ao mundo, à cidade, à prefeitura e aos próprios anunciantes. Medos e desejos imbricados eram "arremessados sobre a realidade", através das fissuras abertas pelas palavras: "Não vamos sair do Centro", "Povo da Rua é para lutar, construir um poder popular".

A marcha tinha uma trajetória pré-definida: da Praça da Sé iria para o Ministério Público e depois seguiria para a Câmara dos Vereadores da cidade. Ao passar pela porta do Ministério Público, representantes do Povo da Rua, dos catadores e do movimento de moradia deixam lá uma coroa de flores com o nome das pessoas mortas. A coroa é para "lembrar o Ministério Público da impunidade do massacre", diz o Padre Júlio, que no microfone coordenava toda dramatização daquele teatro de rua.

Ao chegar à Câmara dos Vereadores, toda a multidão começa a se juntar no espaço exterior. Padre Júlio, ao microfone, anuncia: "Não precisam ficar com medo, a casa é nossa, nós que pagamos por ela”. E todos começam a gritar: “a casa é nossa!” Organiza-se instantaneamente uma assembléia naquele espaço, cobra-se a presença de vereadores e abrese o microfone. Representantes do MMC contam a história do despejo de setenta famílias pela polícia. Um representante do MNCR protesta contra "a política municipal de expulsão dos catadores" e afirma em tom combativo que "nem os catadores organizados e os desorganizados vão sair do Centro”. Neste exato momento, uma figura que, desde o início do cortejo, já aparentava estar um tanto alcoolizada, toma o microfone e começa a louvar o Padre Júlio. Um grupo de jovens religiosos ligados à Toca de Assis, que trajavam roupas de monge 
franciscano e tinham a cabeça raspada, jovens estes muito animados e que durante toda marcha cantarem a dançaram entusiasticamente, ao ouvirem aquela exaltação em direção ao Padre Júlio, em coro começaram a gritar: “viva o Padre Júlio, viva o Padre Júlio...” Aquela exaltação do padre durou muito pouco e foi bruscamente cortada por uma oblata de São Bento da OAF, que ao pegar no microfone disse de maneira severa: "Nós não podemos desviar do foco. Temos que estar muito atentos para tudo o que fazemos. Quem deve ser louvado aqui é o povo da rua e os catadores".

Consertado o descaminho, voltou-se a discutir sobre o papel das personagens do poder público. Padre Júlio, que continuava a comandar toda aquela figuração coletiva, chama o secretário da assistência Floriano Pesaro ao microfone. Contudo, ele não aparece e é criticado pelo padre. Alguns vereadores e outros políticos tomam o microfone e falam. Entre eles está o Subsecretário Nacional dos Direitos Humanos, que afirma que irá ajudar na aceleração das investigações sobre o "massacre da população de rua". Outro representante do MNCR toma o microfone e, com uma boa oratória, diz que "as ruas são também espaços de trabalho" e que os "movimentos populares deveriam se unir e não ficar separados, lutando por seus interesses particulares". Fica combinado que dia 19 de todo mês haveria um encontro na escadaria da Sé, e este encontro seria um ato de vida e não de morte. Às três horas da tarde, após muitas palavras de combate e frases de efeito, chega-se ao fim do evento. É anunciado que haverá um lanche e neste instante toda aquela multidão se dispersa, correndo para a fila. A confusão é tanta que se torna necessário acalmar as pessoas, dizendo que haverá lanche para todos. A fila que se forma é enorme e repleta de pessoas aparentemente de origem simples. Come-se o pequeno sanduíche, toma-se o copinho de suco e, então, vai-se embora.

\subsubsection{Dia de Luta do Povo da Rua - 19/5/2006}

A concentração para aquele ritual público estava marcada para as 13h, no Largo Paissandu. Era uma quinta-feira como outra, no centro de São Paulo, com um enorme trânsito de carros e pedestres, nas ruas e calçadas. Às 13h30, o lugar já estava repleto de pessoas com indumentárias, placas, cartazes e toda aquela parafernália já descrita e própria a estas enunciações e performances coletivas. Seria a $16^{\text {a }}$ edição do "Dia de Luta do Povo da Rua" e a proposta do ato era justamente "dar visibilidade à questão da população de rua na cidade de São Paulo e chamar a atenção das autoridades públicas para este problema”. Era isso que dizia Anderson ao microfone do carro de som do Sindicato dos Comerciários do Estado de São 
Paulo, que fora cedido para o evento. A novidade deste ano é que, pela primeira vez, o Dia de Luta estava sendo totalmente dirigido pelo povo da rua, ou mais precisamente, pelo MNPR.

Nas placas e cartazes os dizeres eram vários e possuíam um caráter eminentemente reivindicatório: "Povo da Rua tem direito a trabalho", "Retorno da operação trabalho", "Moradia", "Melhorar o atendimento no albergue para o Povo da Rua", "Moradia fixa para os idosos e deficientes". Mais uma vez, anseios e desejos, medos e projetos, ainda que inocentes e ambíguos, eram explicitados, expostos e exibidos à paisagem do centro da cidade: "Fim da discriminação e exclusão social", "Diga não ao albergue", "Chega de massacre", "Basta de sofrimento", "O Povo da Rua não merece sofrer", "Paz". Ao lançar tais palavras, escritos e frases à paisagem aberta do Centro, buscava-se torná-las conhecidas e reconhecidas por uma cidade que ordinariamente as desconhecia. Exprimir e anunciar tais coisas implicava em tentar expressar justamente aquilo que não é revelado, aquilo que é escondido: "Para sobreviver nas ruas, é preciso muita força de vontade, para sair dela, só isso não é suficiente", "Morador de rua não marginal, é gente que cria e inventa".

Desta vez, quem coordenava todo o trabalho coletivo de figuração não era mais o Padre Júlio, Vigário do Povo da Rua. Apesar de ter recebido apoio de outras organizações, como Pastoral da Rua, OAF e Rede Rua, quem havia organizado o evento e tomado a frente do palco de atuação eram os personagens diretamente ligadas ao MNPR. E estes falavam sem parar no microfone. Reclamavam, culpavam e reivindicavam ações estatais: "A frente de trabalho foi extinta pela atual secretaria do trabalho", "A secretaria da habitação acabou com os programas habitacionais, a bolsa aluguel”, "Essas qualificações profissionais que querem nos dar não servem para nada, não dá para viver destas coisinhas, isso não alimenta a barriga", "A polícia não sabe lidar com a população de rua, eles batem na população de rua". As falas criticavam sem parar o poder público municipal: "A prefeitura ofereceu 5 mil reais para as famílias dos movimentos de moradia saírem da cidade. Eles querem botar os pobres para fora. Por que não dão trabalho e casa?” As acusações eram efetuadas consecutivamente e as reivindicações não tinham um foco único, eram abertas e heterogêneas: "O Povo da Rua quer trabalho, moradia e cultura", "A higienização do Centro está apreendendo as carroças, as mercadorias dos camelôs e pondo a população de rua para correr", "Trabalho, moradia, educação, saúde e cultura”. Outras demandas, por outro lado, apresentavam e demonstravam certas ambigüidades e controvérsias: "Não queremos ficar pernoitando em albergues!" "Queremos mais albergues e albergues melhores!".

Participavam deste evento representantes de várias instâncias e organizações atuantes na região central. E isso era frisado a todo momento no microfone, como forma de demonstrar 
um apoio coletivo a toda aquela agitação dramática. A lista era grande: o Movimento Nacional dos Catadores de Materiais Recicláveis (MNCR), o Movimento de Moradia do Centro (MMC), a Frente de Luta por Moradia (FLM), o Movimento da Luta Antimanicomial, a OAF, a Pastoral da Rua, a Rede Rua, o Centro Gaspar Garcia, o Instituto Pólis, o Fórum das Organizações que trabalham com a População em Situação de Rua, o Fórum de Debates sobre a População em Situação de Rua e o Fórum Centro Vivo. Esta aglutinação de forças sociais em torno deste evento não era aleatória. Em verdade o "Dia de Luta do Povo da Rua" tinha sido escolhido, antes, como o dia do lançamento do "Dossiê Fórum Centro Vivo". Este documento, que foi resultado de uma produção coletiva efetuada por alguns participantes do Fórum Centro Vivo, buscava denunciar uma série de casos que demonstrassem como as ações estatais desenvolviam violações dos direitos humanos no centro de São Paulo. A proposta era "fazer o debate público a partir das infrações que o poder público desenvolve", como disse um dos participantes do Fórum. O documento possui como alvo cinco categorias de sujeitos com seus direitos "violados" no Centro: as crianças e adolescentes em situação de risco, a população de rua, os catadores de materiais recicláveis, os sem-teto e os ambulantes ${ }^{62}$. Assim, como estratégia a dar maior visibilidade ao Dossiê, foi decidido lançá-lo no mesmo dia do que $\mathrm{o}$ ato. E durante a manifestação, o lançamento do documento era anunciado e lembrado em todo instante no microfone.

Contudo, durante o ato o que mais se fazia era reivindicar. No microfone do carro de som, que parecia não estar funcionando muito bem, as três lideranças do MNPR (Tião, Anderson e Carlos) alternavam-se e demonstravam, em meio aos estalos e ruídos do amplificador, todo o seu "querer": "Queremos oportunidades", "Queremos moradia", "Não queremos moradia provisória, queremos moradia definitiva", "Queremos que o poder público respeite a lei", "Não queremos trabalhar apenas seis meses numa coisinha da frente de trabalho, queremos trabalhar com registro", "Não queremos esmola, queremos futuro". E Tião, que novamente, com sua indumentária, estava todo enrolado num cobertor maltrapilho,

\footnotetext{
${ }^{62}$ O Fórum Centro Vivo nasceu no final da gestão Pitta (1997-2000) e tem como proposta (nos dizeres de um de seus coordenadores) "articular os diferentes grupos e movimentos populares do Centro. Não deixando cada um ficar com seu interesse particular e mostrar que o problema é coletivo". O Fórum reúne-se semanalmente numa sala do Instituto Pólis e recebe apoio direto desta instituição. Participei e acompanhei algumas das reuniões do Fórum antes do lançamento do Dossiê, e nestes encontros, representantes de vários movimentos sociais do centro participaram ativamente sobre questões atreladas à produção deste documento. Ao freqüentar estas reuniões, percebi que existem "altos e baixos" na vida deste Fórum. Como um dos principais organizadores explicou: "o Fórum nasceu quente na gestão Pitta e na gestão Marta o negócio esfriou". Parece, contudo, que a atual gestão municipal permitiu um "reaquecimento" do Fórum, pois, segundo este mesmo participante, "o Serra possibilitou juntar mais os interesses sociais do Centro. Neste contexto de violência, o Fórum passou a articular vários movimentos de resistência contra a violência da prefeitura" (Caderno de campo, 06/05/2006). E esta violência referida diz respeito às ações públicas que violaram direitos humanos, que justamente o Dossiê buscava denunciar.
} 
gritava no microfone: "quem quer trabalho aí?” E o público, dissonantemente, respondia: “eu!”. E os “quereres” não acabavam, pois em verdade eram bem amplos: "Queremos a cada seis meses um campeonato de futebol”. Esta heterogeneidade das reivindicações apresentavase nas falas, nos cartazes e placas e também na camiseta do MNPR, que muitos manifestantes usavam. Nela podia-se ler: "Fazer Justiça séria - Por moradia, trabalho, saúde, educação, cultura. Pelo fim da violência”.

E aquele aglomerado de gente no Largo Paissandu não só ouvia falas e discursos, mas também dançava e dançava muito. Como de costume em eventos públicos deste tipo, e especialmente neste, certos personagens do entorno, figuras de rua, alguns maltrapilhos, outros com o rosto inchado de bebida, iam se aproximando por curiosidade ou interesse. E com o tempo, aquele teatro de rua ia ganhando mais atores e mais movimento, pois os novos personagens pareciam gostar muito de dançar: pulavam, bailavam, giravam, sorriam, brincavam. Tiveram até que fazer uma roda, para tentar organizar toda aquela folia carnavalesca.

Ao colocar-se em marcha, aquele evento foi ganhando aspecto de cortejo, se bem que um cortejo não muito arrumado. Junto com o carro de som, que teve de ser trocado devido a problemas técnicos, um aglomerado de pessoas, bandeirolas, batuque, cartazes e carroças atravessavam o vale do Anhangabaú. O ato que tinha iniciado no Largo Paissandu, em frente à Secretaria Municipal do Trabalho, estava movendo-se em direção à Secretaria Municipal da Assistência e do Desenvolvimento Social. O mesmo procedimento efetuado em relação à Secretaria do Trabalho foi realizado em relação à Secretaria da Assistência. Tião ao microfone perguntava para o público: "Cartão amarelo ou vermelho para esta secretaria?". E numa vaia geral o coro desarmônico do público respondia: "Vermelho". Então Sebastião sacava do bolso um cartão vermelho e o levantava, em direção ao órgão público.

Toda aquela figuração vira à direita na Rua Líbero Badaró e então para em frente à Secretaria da Habitação, fazendo a maior algazarra. Enquanto se repete o mesmo procedimento do cartão, os veículos, que ficaram impedidos de continuar a transitar pela rua tomada, ficam buzinando sem parar e o barulho aumenta mais ainda. Parecia que a manifestação tinha agora aumentado de tamanho. Estava maior, com mais gente e fazendo mais balbúrdia. Tinha até aparecido mais um carro de som, de tal maneira que agora eram dois carros de som, funcionando e auxiliando na polifonia e na vozearia. Toda aquela falação continuava e várias pessoas pegavam o microfone para discursar ou cantar. Davam depoimentos, choravam, contavam histórias, lembravam, se indignavam. O drama corria solto. Tudo ao mesmo tempo e em alto som. 
Finalmente o desfile chega à Praça Patriarca, em frente à sede da Prefeitura. Só que isto não estabiliza a manifestação, o alvoroço permanece. É solicitada a entrada de uma comissão de seis pessoas para falar com o prefeito Kassab (vice-prefeito de José Serra, que assumiu a gestão quando o último tornou-se governador do Estado de São Paulo) e entregar uma lista de reivindicações. Tal audiência já havia sido solicitada com meses de antecedência pelo MNPR e era de grande importância. O vereador Paulo Teixeira (PT) havia apresentado um projeto de lei, proposto por alguns integrantes do MNPR, no qual estabelece que as empresas prestadoras de serviço para a Prefeitura ficam obrigadas a contratar $2 \%$ de pessoas em situação de rua para a execução das tarefas que exigem qualificação básica. O projeto, que tinha sido aprovado pela Câmara Municipal no dia anterior, dependia agora só da sanção do prefeito. Outra questão é que se pretendia dar uma edição do Dossiê Fórum Centro Vivo pessoalmente ao prefeito e fazê-lo da maneira formal. Daí a importância do encontro. Lá na porta de entrada da Prefeitura, um punhado de indivíduos reúnem-se para decidir quem vai integrar a comissão. E na confusão daquele instante, quase sai briga. Parece que uma pessoa queria falar com o prefeito "nem que fosse na força". Integram a comitiva, então, quatro representantes da população de rua, um representante dos catadores de materiais recicláveis e o Padre Júlio Lancelotti, que só neste momento aparece como uma personagem mais ativa no cenário.

Enquanto a comissão está lá dentro, o microfone continua a lançar frases e palavras de efeito ao público, ao poder municipal e à cidade: “A prefeitura prometeu 1.500 novas vagas na operação inverno e nós vamos cobrar", "É um absurdo o massacre do Povo da Rua ficar imune, o Estado não fez nada", "Os políticos só roubam, não fazem política pública só para fazer caixa dois". Enquanto a efervescência continuava Padre Júlio sai da prefeitura e dizendo que a comissão não foi aceita pelo prefeito. De novo vaia geral. "Com este prefeito nunkassab", "Kassab pipoca". A escolha era, ou falar agora com um de seus assessores, ou falar com o prefeito noutro dia. Deixam para um outro dia.

A manifestação prossegue em direção à Câmara Municipal de São Paulo, tudo acompanhado pela guarda municipal e pela CET (Companhia de Engenharia e Tráfego). Ao chegar lá, aquele aglomerado de pessoas começa a se organizar para fazer uma assembléia. Aparecem alguns vereadores da Câmara Municipal, entre eles Paulo Teixeira (PT) e Soninha Francine (PT), assim como o próprio presidente da Câmara, Roberto Trípoli. Anderson pega o microfone e discursa: "Nunca um prefeito de São Paulo ousou receber um morador de rua em audiência, hoje seria a primeira oportunidade e foi deixada de lado pelo Kassab”. Sebastião, enrolado em seu cobertor, também fala: "Cadê o prefeito? Cadê o prefeito? Temos que 
colocar uma faixa na frente da Prefeitura - Precisa-se de prefeito". Os vereadores também discursam e enquanto Trípoli entusiasmadamente falava, uma daquelas peculiares alteridades maltrapilhas, que acompanhara todo o trajeto do alvoroço, retrucava da platéia: "não acreditem nele, é mentira, é mentira!" Isso deixou o presidente da câmara um bocado incomodado, de modo que mais de uma vez teve de afirmar: "isso que eu estou falando é verdade, eu não minto!”.

Um representante do MNPR de Belo Horizonte comenta da situação em sua cidade e diz que "não devemos ficar agradecendo estes políticos, eles só fazem o que deveriam, nada de mais". É lembrado que este é o primeiro Dia de Luta do Povo da Rua que foi totalmente dirigido pela população de rua. Ouvem-se representantes de outros movimentos e organizações. Logo após estas falas, todos são convidados a comer um pequeno lanche e ir para o auditório do Sindicato dos Engenheiros no Estado de São Paulo (SEESP), localizado a uma quadra dali, onde seria apresentado oficialmente o Dossiê Fórum Centro Vivo. Enquanto todos comem seu sanduíche e fruta, um batuque homenageia Adoniran Barbosa no microfone, saudosa maloca.

Alguns dias depois deste evento, o prefeito veta o projeto de lei da dotação orçamentária da população de rua.

\subsubsection{Abaixo a Repressão aos catadores - 20/6/2006}

A concentração estava marcada para as $9 \mathrm{~h}$ em frente à Catedral da Sé. Eram umas 9h30 e já tinham chegado algumas carroças. Ao aproximar-se do agrupamento de pessoas, recebi um papelzinho escrito "Carta Aberta à População", que dizia: "Nós catadores e catadoras da cidade de São Paulo, vimos mostrar a toda sociedade nossa indignação quanto às ações da Prefeitura de São Paulo em relação à categoria dos catadores. Esta prefeitura vem apreendendo nossos materiais recicláveis e proibindo nosso trabalho com agressões e ameaças”. Contava um pouco sobre o Movimento e mais ao longo da carta era possível ler: "Somos uma categoria, que gera economia de energia, matéria prima para a indústria, benefício para o meio ambiente com a coleta de parte dos resíduos sólidos produzidos na cidade, dando vida útil aos aterros sanitários. Esse trabalho é realizado gratuitamente, muitas vezes sem a infra-estrutura do poder público, enquanto a Prefeitura paga para empresas privadas cerca de 90 reais por tonelada coletada”.

O principal motivo da manifestação foi chamar a atenção do poder público para os catadores. Muitas carroças estavam sendo impedidas de circular pela cidade e foram 
apreendidas pela polícia e pela fiscalização. Outra crítica à prefeitura era de que se queria que os catadores fossem reconhecidos como uma categoria de trabalho e incluídos no programa de coleta seletiva, já que eram mais de 20 mil em toda cidade e estes eram responsáveis por quase $90 \%$ do material reciclável coletado.

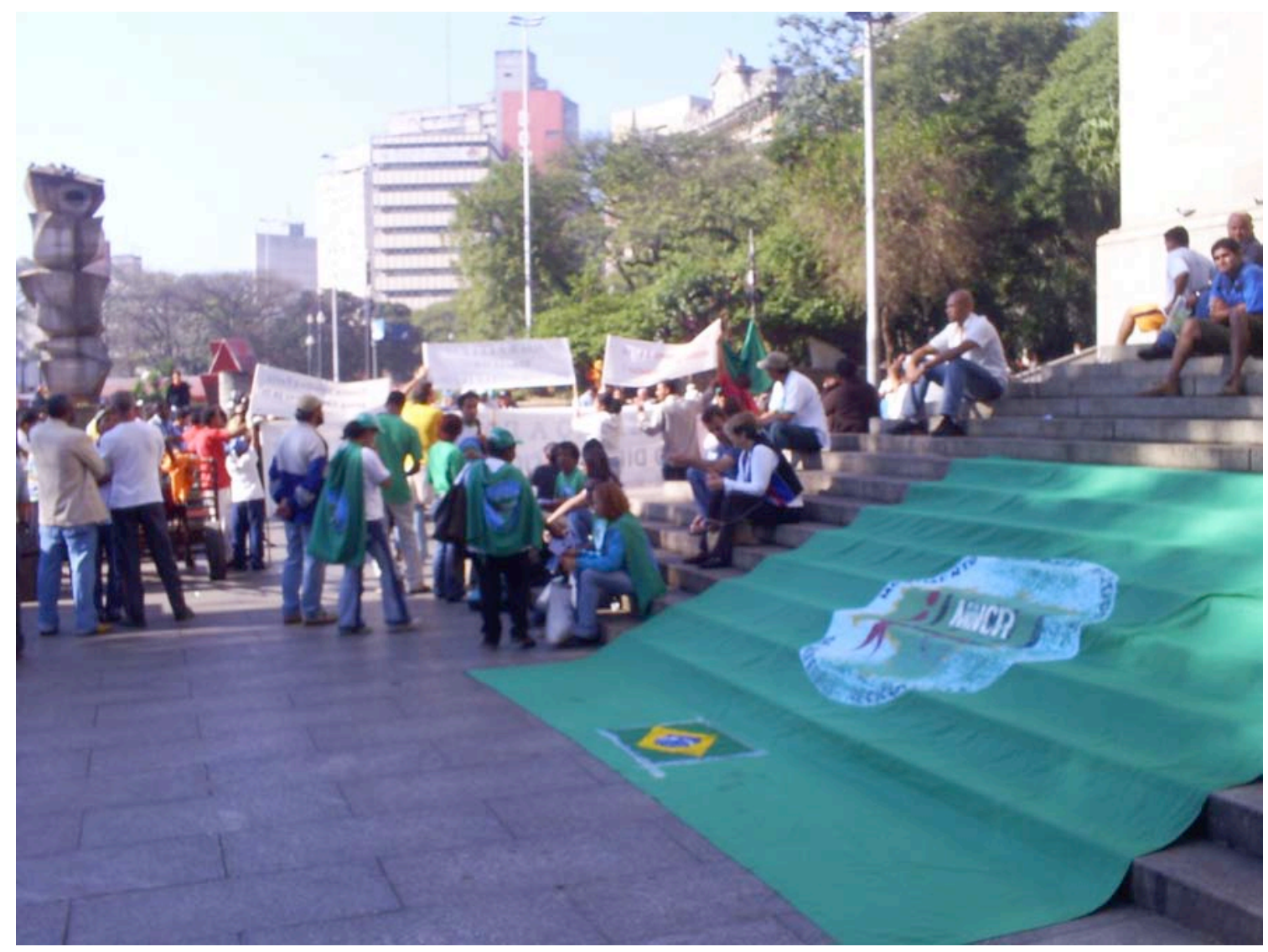

Momento de concentração em frente à Catedral da Sé.

Foto: Daniel De Lucca Reis Costa

Em verdade tinham poucas pessoas naquele evento. Comparado com o anterior, este era bem menor. Havia lideranças do MNCR e catadores provenientes de cooperativas de outras regiões da cidade e até mesmo de outras cidades, como Baixada Santista, Ourinhos e Avaré. Contudo, estavam presentes não só figuras ligadas ao movimento dos catadores. Também estavam ali pessoas ligadas ao MNPR, como Anderson e Sebastião, sendo que este último chegou comentando que a falta de organização impediu a impossibilidade de uma maior mobilização coletiva para o evento. Encontrei também alguns participantes do Fórum Centro Vivo e de outras organizações atuantes no centro de São Paulo.

Foi aberta uma grande bandeira do Movimento Nacional dos Catadores de Materiais Recicláveis (MNCR) e deixada na escadaria da Catedral da Sé, para dar mais visibilidade ao 
símbolo. Todos aqueles badulaques de manifestações estavam mais uma vez presentes. Placas, bandeiras e faixas com vários dizeres: "Abaixo a repressão, catador é profissão", "Coleta seletiva feita pelos catadores já". Alguns dizeres enfatizavam aquelas dificuldades vividas cotidianamente que ali podiam ser exprimidas publicamente: "Cada carroça tem seu peso. E a discriminação, quanto pesa?" Outros escritos demonstravam alianças: "Catadores e Povo da Rua unidos na luta popular". Até mesmo as alianças com os objetos, no enfrentamento e na luta da vida ordinária, também eram expostas: "A carroça é a extensão da luta pela sobrevivência”.

O carro de som era, de novo, o do Sindicato dos Comerciários do Estado de São Paulo. E no som rolava o cd do MNCR. Todas as músicas possuíam um caráter popular, tinha de xote até hip hop, e as letras falavam sobre a vida do catador. Ao som da música, muitas pessoas dançavam e brincavam. Ao perguntar para Anderson sobre o carro de som do sindicato, ele explicou: "Depois do massacre do Povo do Povo da Rua, os comerciários do Centro foram muito criticados e a partir disso começaram a apoiar os dois movimentos". Também fiquei sabendo posteriormente que o lanche, servido no final do "Dia de Luta", foi uma doação do mesmo sindicato.

Enquanto a concentração permanecia na Sé esperando mais pessoas chegarem, uma equipe de reportagem do SBT aparece e começa a filmar e entrevistar vários catadores. Logo após, chegam mais repórteres para registrar aquele teatro, um da rádio Record e outro do Diário de São Paulo. Distribuem-se pelo púbico, fotografam placas e claro que preferem entrevistar aqueles que estavam com suas carroças, pois deste modo a imagem registrada seria a de um catador mais "autêntico".

O aglomerado de pessoas, carroças, carro de som, placas e bandeirolas do MNCR começam a se locomover em conjunto. E a movimentação é feita de maneira ordenada, com a bandeira grande do movimento na frente e o resto da comitiva, com o carro de som, atrás. A marcha tinha inicialmente a proposta de chegar à sede da Prefeitura pela XV de Novembro, mas como os coordenadores não conseguiram a autorização da CET para o carro de som subir no calçadão, seguiram o caminho da rua mesmo. 


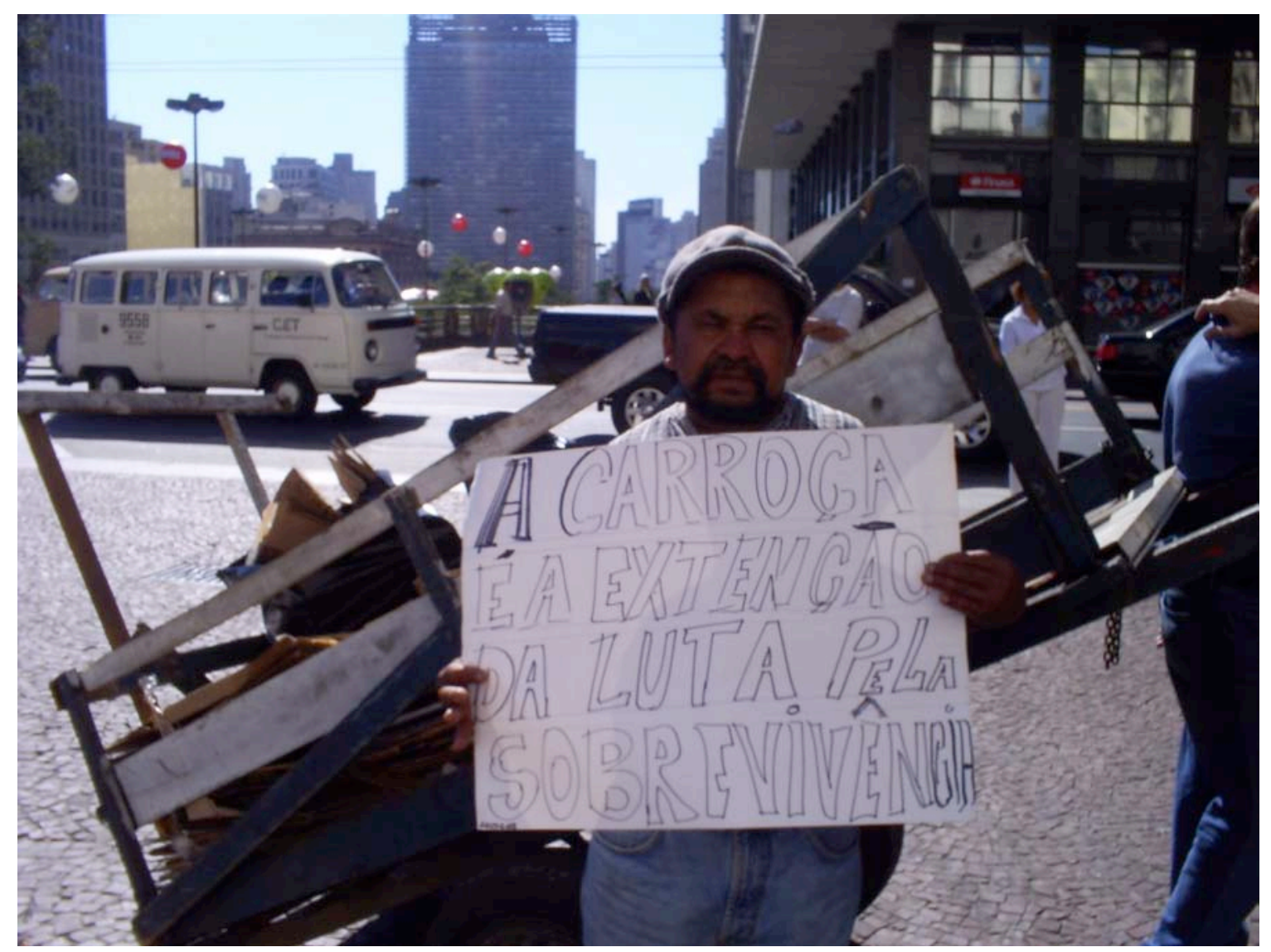

Em frente à Prefeitura, carroceiro expressa sua relação com instrumento de trabalho.

Foto: Daniel De Lucca Reis Costa

E o microfone não parava de funcionar: "Catador não quer esmola, quer trabalhar", "Queremos apoio, não a ingerência do poder público", "Coleta seletiva sem catador, é lixo", “A Prefeitura não reconhece nosso trabalho, toma nossas carroças e não deixa a gente reciclar. São eles que estão poluindo a cidade e não nós". Luta-se verbalmente para imprimir novos sentidos às coisas do mundo: "Não queremos ser tratados como lixo, não trabalhamos com lixo, trabalhamos com material reciclável”. E neste processo de negociação dos sentidos, deslocamentos semânticos novamente são operados: "Lixo não é lixo", "Material reciclável não é sujeira, é recurso, é economia”. Busca-se dar novo status a uma categoria marcada pelo estigma: "O catador deve ser visto não como um marginal, e sim como um profissional, um agente ambiental", "O catador sabe mais sobre o lixo da cidade do que qualquer técnico em logística da Prefeitura”.

Mais uma vez, como em jogos de linguagem, gritos de guerra e palavras de batalha são os projéteis aqui lançados: "Catador organizado jamais será pisado". Pretende-se demonstrar a irredutibilidade da enunciação pública: "Com chuva, com vento, não pára o movimento". Imagens de si são também expressas e impostas: “1, 2, 3, 4, 5, mil, estamos 
defendendo a natureza do Brasil". E do microfone gritam: "Recicla ou não recicla?". E em coro desarmônico o público responde: "recicla".

Assim, todo o cortejo ia cantando, dançando, brincando e caminhando pelo centro de cidade. Aquele agrupamento em movimento era como uma retórica ambulante que, ao caminhar, lança discursos, frases e sentidos para todos os lados. Seu trajeto produzia territorialidade, ia balizando o espaço, ia demarcando a paisagem da cidade com todos seus pontos históricos: Catedral da Sé, marco zero, Pátio do Colégio, Ladeira Porto Geral, Mosteiro São Bento, Vale do Anhangabaú, até a Praça Patriarca, onde se via o Viaduto do Chá e a sede da Prefeitura, conhecida também como "prédio do banespinha". No momento em que passava pela Rua Libero Badaró, aquele chamativo desfile de palavras, pessoas e carroças em ebulição, produziu mais repercussão ainda. No alto corredor de prédios, formado ao longo da rua, pessoas apareciam nas janelas e respondiam com gritos, assovios, palmas e acenos. Aquele alvoroço coletivo, que pelo meio da rua se movia, ganhava a cidade como platéia.

Mais uma vez ao chegar em frente à sede da Prefeitura, o desfile pára. A grande bandeira do movimento é colocada no chão, de maneira a enfatizar sua presença. As carroças procuram lugar para estacionar. As placas e cartazes começam a se ajeitar. É definida uma comissão para ter a audiência com o prefeito, uma audiência que já tinha sido marcada e aceita. A comissão era composta por 4 catadores do comitê da cidade e 1 "companheiro", Anderson do MNPR, representando os catadores avulsos ${ }^{63}$. Quando a comissão subiu, eram cerca de meio dia.

Mas o microfone não parava: "Os catadores fazem o serviço que a Prefeitura deveria fazer, não são reconhecidos e ainda são impedidos de trabalhar", "Todo ano têm uma verba para a coleta seletiva, só que ninguém sabe o que é feito dela". As críticas eram fortes e se direcionavam justamente ao estabelecimento que se encontrava à frente dos manifestantes. Enquanto isto mais repórteres fotografavam, entrevistavam e filmavam os manifestantes. Outras carroças e carroceiros que passavam por ali, ao verem aquela aglomeração de semelhantes, aproximavam-se para saber do que se passava. Uma hora e meia depois, a comissão desce dizendo que foi aberto um canal de contato com a prefeitura e que esta mesma comissão seria a responsável pela interlocução com o poder público.

\footnotetext{
${ }^{63}$ Ao perguntar para Anderson sobre o porquê dele integrar a comissão, me disse: "Eu não queria subir, o pessoal do Movimento (da população de rua) nem deu autorização, mas como o Bispo (um participante do MNCR) tem ajudado pra caramba a gente, ele insistiu para eu ir por achar importante".
} 


\subsection{Como se luta num campo de conflitos}

As cenas aqui descritas narraram estratégias e modos de luta que não se remetem univocamente às circunstâncias pelas quais foram acionadas. São reiterações de práticas históricas, convenções e formas passadas traduzidas conjunturalmente. As políticas de rua, manifestas nos últimos quatro eventos etnografados, dissimulam um repertório de esquemas de ação que remetem às antigas práticas desenvolvidas pela Missão do Povo da Rua. Momentos passados desta trama, quando então, depois de vigílias noturnas e liturgias cristãs, se saía às ruas da cidade com o intuito de fornecer maior visibilidade à "periferia do centro" e afirmar publicamente que estes sofredores são "um povo que quer viver". Neste período histórico, as referências religiosas da Comunidade dos Sofredores de Rua serviram para dar inteligibilidade ao sofrimento das ruas e ao fortalecimento frente às incertezas do futuro. Além disso, nesta Comunidade foram urdidas práticas moleculares que constituíram canais onde se sedimentou uma experiência de luta que foi de fundamental importância reivindicatória para as conjunturas de enfrentamento posterior. Muitas destas atividades assemelhavam-se às romarias e procissões, práticas populares carregadas de conteúdos religiosos e místicos. Nota-se, assim, que tais práticas encontram-se na própria origem dos dois movimentos sociais, MNCR e MNPR.

Apesar de ambos os movimentos terem nascidos em contextos distintos, suas problemáticas alcançam dimensão nacional justamente em 2001, na $1^{\text {a }}$ Marcha Nacional da População de Rua e dos Catadores de Materiais Recicláveis. Deste modo, a velha tradição das romarias - peregrinações rumo a um santuário, centro religioso onde o sagrado se manifesta foi transformada primeiramente pelas Missões e Dias de Luta da População de Rua, na cidade de São Paulo, e depois pela $1^{\text {a }}$ Marcha Nacional, que mobilizou um grande número de caravanas e comitivas em direção ao centro político do país. Deste modo, vemos como as primeiras formas, no desenrolar da história, adquiriram conteúdos políticos ${ }^{64}$.

Assim, o nexo entre religião e política apresenta-se como um importante eixo no desenvolvimento subjacente dos acontecimentos etnografados. Até porque a maciça presença de emblemas religiosos - como a Catedral da Sé, os sacerdotes e a cruz carregada -, foi transformada em símbolos da luta política. Em todos os eventos descritos, o principal foco de atenção foi o poder público, em sua multiplicidade de alvos locais. Nestes rituais políticos, atores, discursos e palavras foram lançados em direção às autoridades públicas, secretarias

\footnotetext{
${ }^{64}$ Sobre as relações entre marchas, procissões e peregrinações, no contexto da luta política do Movimento dos Sem-Terra, ver o excelente trabalho de Cristiane de Alencar Chaves (2001).
} 
municipais, instituições jurídicas, órgãos do legislativo e prefeitura. Estes modos de embate, que carregam consigo formas de enunciação forjadas em experiências anteriores, são algumas das estratégias nas quais se luta neste campo de conflito cruzado pelo antagonismo. Gostaria, agora, de discutir um pouco melhor sobre o caráter antagônico do conflito aqui exposto para, posteriormente, discorrer sobre os diferentes modos de enunciação coletiva apresentados nos eventos.

\subsubsection{Antagonismo e fusão de reivindicações}

O conjunto dos estudos sobre movimentos sociais urbanos, efetuados nas décadas de setenta e oitenta, concentrados principalmente em cidades como São Paulo e Rio de Janeiro, constituiu-se um paradigma nas ciências sociais brasileiras. E como todo paradigma, este carregava consigo alguns pressupostos: os movimentos seriam expressões populares "espontâneas", "independentes" e "por natureza" contra o Estado e seus aparatos institucionais e burocráticos (Silva; Ribeiro, 1985, Cardoso, 1987). Obviamente, estes pressupostos refletiam um presente histórico consideravelmente distinto do nosso, quando então, o peso do regime militar de um Estado centralizador, e inegavelmente autoritário, pairava sobre a imaginação sociológica nacional, agindo sobre os próprios modos de compreensão da realidade que se buscava investigar. Contudo, foi a autocrítica e o desenrolar destes mesmos estudos que permitiram começar a ressaltar a diversidade existente no interior das chamadas classes populares, suas formas heterogêneas de reconhecimento e pertencimento, bem como todo o complexo universo simbólico nos quais são constituídos os discursos que nomeiam os aliados e adversários, aqueles que estão "deste" ou do "outro lado" (Sader, 1988, Caldeira, 1989).

Nos cinco eventos descritos, o alvo dos discursos e das enunciações performáticas foi justamente o Estado, ou mais precisamente, algumas de suas facetas mais locais e circunscritas, como instituições e autoridades do executivo, legislativo ou judiciário. No entanto, estas facetas e especificidades das agências públicas, muitas vezes foram diluídas pelos discursos dos próprios atores, que apresentavam o poder público como alvo privilegiado dos embates. A grande diversidade de atores, interesses e reivindicações, manifestas nestes rituais públicos, coligaram-se através de um eixo articulatório que reconhecia como "injusta" as práticas desenvolvidas pela atual gestão municipal. Uma experiência de justiça, não transcendental, mas que foi produzida através de múltiplas trajetórias passadas, acontecimentos precedentes e também relações com os poderes municipais anteriores. A 
mudança mais recente nas práticas políticas municipais incitou a mobilização conjuntural de um amplo arco de diferentes forças sociais atuantes no Centro. As atuações da atual gestão local, ao estabelecerem certas descontinuidades políticas, no que se refere às demandas das classes populares, contribuíram para a construção de um campo de conflitos atravessado pelo antagonismo. Antagonismo acirrado, que permitiu traçar conexões em um extenso complexo discursivo, operando como possíveis momentos de totalização e articulação entre diferentes movimentos sociais, entidades e organizações não governamentais, fóruns e sindicatos, personalidades políticas e religiosas, entre outras.

Em 2001, assistimos a uma expressiva mudança no processo de intervenção em curso no centro de São Paulo. Contudo, a dinâmica instituída pela gestão municipal do PT (20012004), apesar de ter permitido espaços de interlocução, abrindo-se para a possível negociação de interesses diversos e conflitantes, também é hoje objeto de questionamento por vários segmentos populares, principalmente com relação à falta de resultados concretos, bem como à tendência de manipulação e instrumentalização dos espaços participativos ${ }^{65}$. Ao mesmo tempo em que esta gestão se aproxima de certo conjunto de categorias provenientes das chamadas classes populares, ouve suas demandas políticas e assinala para possíveis realizações, estes segmentos ficam na expectativa da efetivação de seus anseios, permanecendo mais atrelados à dinâmica, burocracia e interesses ligados ao poder público. Em outras palavras, a gestão PT, ao acenar para os movimentos sociais, grupos sociais organizados e outros atores que se vinculam a certos estratos dos setores de baixa renda do Centro, possibilitou uma desmobilização e desarticulação política destes, coisa que não ocorreu, como aqui foi possível constatar, na gestão posterior.

Quatro anos depois, a nova prefeitura (Serra, PSDB-PFL) ao tomar posse e não estabelecer qualquer canal de interlocução com o leque de atores ligados às classes populares da região central - tratando-os como empecilhos e obstáculos a serem ultrapassados e de certa forma retomando aquele discurso anterior da Associação Viva o Centro, pautado por práticas de gentrification -, possibilitou uma maior articulação entre um conjunto de atores, colocados

\footnotetext{
${ }^{65}$ No início da gestão Marta, a prefeitura estabeleceu relações amistosas com algumas cooperativas de materiais recicláveis, com a intenção de se construir um programa conjunto de coleta seletiva para toda a cidade. Entretanto a construção conjunta deste programa de coleta, assim como o diálogo com as cooperativas, foi abolida no decorrer do mandato. O que se viu em 2002 foi a implementação acelerada de um programa de coleta seletiva arbitrário, que não acompanhou em nada as metas do projeto pelo qual fora definido; que diminuiu o material reciclado encontrado nas ruas, dificultando o trabalho dos catadores; e que gerou uma grande impopularidade, devido ao surgimento de uma nova taxa sobre o lixo na cidade de São Paulo (De Lucca, 2007). O mesmo caso de corte de diálogo ocorreu com os movimentos de moradia da região central. Houve uma intenção inicial da prefeitura em responder às demandas por moradia popular no Centro através do projeto "Morar no Centro"; contudo, há fortes indícios que demonstram como esta questão foi muito timidamente contemplada até o final da gestão Marta (Frúgoli Jr., 2005b).
} 
agora em situação rebaixada e sob constante pressão do poder público. Entre estas atitudes políticas da nova gestão, poderíamos citar: a captura das carroças dos catadores e a tentativa de desativar certas cooperativas; a expulsão dos "nóias", prostitutas, travestis e outras "sociabilidades marginais" (Arantes, 2000) da chamada "cracolândia"; o banimento dos moradores de rua do espaço público do Centro; o encerramento dos programas de moradia social para a região; o fechamento dos espaços de diálogo existentes; o fim dos convênios e a pressão sobre algumas organizações não governamentais ${ }^{66}$. Estas práticas da prefeitura produziram um amplo impacto negativo num conjunto de experiências urbanas extremamente diferenciadas na região central. Assim, os segmentos envolvidos, ao mobilizarem-se publicamente, associaram-se e encararam-se reciprocamente, experimentando sentimentos comuns, produzindo e compartilhando significados sobre si e sobre o Centro. A sequiência de eventos permitiu aos participantes descobrirem propriedades comuns para além da diversidade de situações particulares, que poderiam isolar, dividir ou desmobilizar, construindo conjunturalmente, uma identificação coletiva mais ampla.

A atual gestão, ao produzir significativas descontinuidades em relação à passada, principalmente no que se refere aos modos de relacionamento com um conjunto diferenciado de atores, apresentou-se como uma alteridade e opositora radical, permitindo assim, a unificação de um amplo espectro de diferenças sociais, ainda que situacionalmente ativada. Com tais atitudes, provocou uma dualização do campo de conflitos. Campo extremamente multifacetado, plural e, desde a gestão anterior, marcado por uma certa dispersão das reivindicações e dos espaços de interlocução política. Ao colocar-se como pólo complementar e exterior constituinte dos "interesses populares" - interesses estes que não possuem, em si mesmos, nenhuma unidade ou identidade prévia -, as ações da prefeitura contribuíram para a construção de uma ampla frente de representantes dos mesmos. A situação de dificuldade na qual um conjunto plural de atores se encontrava e a pressão do poder público sobre estes, permitiram orquestrar distinções e diferenças, construindo um campo de forças marcado por dois pólos complementares de identificação: o poder público e os atores vinculados aos "interesses populares". Este antagonismo, a despeito de ser extremamente precário e provisório, produziu uma real fusão de discursos, reivindicações e demandas políticas. O auge da conjuntura que permitiu esta fusão foi o lançamento do Dossiê Fórum Centro Vivo. Naquele evento, estava presente uma enorme multiplicidade de categorias de atores, que só

\footnotetext{
${ }^{66}$ Todos estes eventos podem foram relatados e podem ser encontrados com maior detalhamento no Dossiê de Denúncia Fórum Centro Vivo (2006).
} 
por estarem juntos na manifestação, já demonstravam uma conexão articulatória entre um conjunto diversificado de posições e espaços de luta política ${ }^{67}$.

Contudo, esta fusão de reivindicações não é algo permanente, e, sim, conjuntural. $\mathrm{O}$ comentário de um dos organizadores do Dossiê sobre o fato de que o Fórum Centro Vivo, enquanto instância de articulação política entre diferentes segmentos populares da região, tenha "esfriado" na gestão anterior e agora "esquentado", demonstra a oscilação na articulação das diferenças entre os diversos atores envolvidos. Esta oscilação ficou explícita quando, um mês depois do lançamento, o Fórum Centro Vivo tinha dificuldade em angariar participantes para suas reuniões. Não obstante, parece que o principal motor desta articulação momentânea de interesses distintos foi justamente o início da nova gestão que, ao desenvolver mudanças locais súbitas mediante práticas políticas antagônicas a um dado conjunto de atores, incitou uma forte articulação entre forças heterogêneas que, no entanto, logo após o lançamento deste Dossiê, foi aos poucos enfraquecendo em suas conexões.

A fusão de projetos políticos e reivindicações heterogêneas não representa uma unidade, tampouco uma somatória de interesses dispersos e parciais, mas sim uma diversidade que apresenta temporariamente elementos aglutinadores, em torno de um opositor comum. Claro que nos eventos descritos, certas agências públicas mais específicas foram também alvo de críticas e discursos por parte dos manifestantes, embora, sem sombra de dúvida, o opositor privilegiado nas mobilizações tenha sido a própria prefeitura, tornada alvo de acirradas pressões e reivindicações. Contudo, este antagonismo binário, de maneira alguma é uma realidade prévia, pois se constitui como o resultado conjuntural de uma plêiade de reivindicações e itinerários de luta plurais, construídos nos inúmeros cenários da vida social. Estes vínculos e conexões traçados entre diferentes forças sociais atuantes no Centro não são elementos dados, mas articulações que requerem condições muito particulares para sua emergência, como, por exemplo, a encenação da própria prefeitura como um exterior constitutivo dos setores populares. Estas experiências, inseridas no fluxo e refluxo dos acontecimentos históricos, podem se agregar ou não, produzindo algum significado - ainda que circunstancial - para a própria noção de "popular", uma categoria que guarda elos muito

\footnotetext{
${ }^{67}$ Apenas com a intenção de reforçar o caráter plural dos interesses e atores envolvidos neste evento, é que os cito novamente: Movimento Nacional de Luta e defesa pelos Direitos da população em Situação de Rua (MNPR), Movimento Nacional dos Catadores de Materiais Recicláveis (MNCR), o Movimento de Moradia do Centro (MMC), a Frente de Luta por Moradia (FLM), o Movimento da Luta Antimanicomial, a OAF, a Pastoral da Rua, a Rede Rua, o Centro Gaspar Garcia, o Instituto Pólis, o Fórum das Organizações que trabalham com a População em Situação de Rua, o Fórum de debates sobre a População em situação de Rua e o Fórum Centro Vivo, Centro de Mídia Independente (CMI), entre outros agentes coletivos cuja presença não pude identificar.
} 
complexos com a de "classe" e que de maneira alguma pode ser tratada em termos de unidade (Sader; Paoli,1997).

Entretanto, ao reiterar o antagonismo exposto e afirmado na cadeia de rituais públicos, corre-se o risco de simplificar as próprias especificidades e diferenças existentes no interior do Estado, das chamadas classes populares, dos múltiplos agentes de mediação e apoio, bem como nos diversificados canais de interlocução e negociação em que estes agenciamentos ventilam e circulam uns nos outros. Assim, na tentativa de detalhar um pouco melhor certas diferenciações existentes no interior de algumas categorias das camadas populares e os feixes de força e sentido que as atravessam, é que pretendo discorrer rapidamente sobre as relações de alteridade envolvidas nos processos de identificação política, nos quais os movimentos sociais evocados estão inseridos.

\subsubsection{O discurso da população de rua frente suas alteridades fronteiriças}

Alguns dos estudos sobre população de rua definem a mesma como o exemplo máximo daquilo que é chamado de exclusão social (Burztyn, 1997; Escore, 1999; Nasser, 2001). Já outros estudos mais recentes, apontam como caracterizador comum deste contingente, um intenso processo de desvinculação e desqualificação social (Rosa, 2005). Esta diferenciação é importante, pois enquanto no primeiro caso enfatiza-se mais um estado a exclusão -, no segundo demarca-se um processo - a desfiliação ${ }^{68}$. Contudo e com as devidas diferenciações, ambas as abordagens convergem para o fato de privilegiarem o aspecto negativo e as carências que caracterizam este contingente, denotando, no primeiro caso, uma ausência de vínculos e, no segundo caso, um processo de perda de vínculos. Tanto para as concepções que enfatizam a exclusão, quanto aquelas que enfatizam a desfiliação, os vínculos sociais referem-se fundamentalmente ao mundo da casa e ao mundo do trabalho. Assim, proponho nesta seção, ainda que um tanto esquematicamente, utilizar-me destes dois eixos - a casa e o trabalho - como balizas e formas simbólicas privilegiadas para explorar a diferença do discurso da população de rua frente a outros dois modos de identificação também presentes

\footnotetext{
${ }^{68}$ Foi esta preocupação, de chamar a atenção para os dinâmicos processos nas quais as pessoas de rua estão inseridas, que fez com que se passasse a utilizar também a expressão população em situação de rua. O uso da noção de situação, neste caso, foi proposta pelos trabalhos de Serviço Social da PUC-SP, trabalhos estes muito influenciados pelas obras de Robert Castel (1993, 1998) e Serge Paugam (1999). Vale comentar que Aldaíza Spozati, professora desta instituição e secretária municipal da assistência social na gestão Marta (PT, 20012004), teve um importante papel ao introduzir, no interior do poder público, esta concepção mais dinâmica da situação de rua.
} 
nos rituais públicos: os movimentos de luta por moradia e o Movimento dos Catadores (MNCR).

Segundo Pierre Bourdieu, a manifestação é "um ato tipicamente mágico através do qual o grupo prático, virtual, ignorado, negado, reprimido, torna-se visível, manifesto, tanto para os outros grupos quanto para si mesmo, atestando sua existência enquanto grupo conhecido e reconhecido, e afirmando sua pretensão à institucionalização" (Bourdieu, 1996:112). Assim, estas manifestações pretenderam mostrar a um espaço público dado, ao poder público e aos próprios atores engajados, ainda que por formas inacabadas e repletas de ambigüidades, imagens fugazes pelas quais desejariam ser conhecidos e reconhecidos. Estas mobilizações sociais estavam envolvidas em lutas em torno de jogos de verdade, nestes agenciamentos de enunciação problematizaram a si mesmo e evidenciaram certos pontos de identificação. É esta abertura intersticial de posições que, ao operar um espaço para a colocação de diferenças e equivalências, evocam interlocutores e alteridades. Todos estes "outros", cuja ausência se faz presente no discurso, são constituintes dos processos de subjetivação, nos quais os movimentos sociais e suas posições de sujeito estão inefavelmente atreladas. (Laclau; Mouffe, 2004).

Deste modo, ao explorar a fronteira articulatória da população de rua, mediante a interpretação das relações diacríticas com outras categorias de reconhecimento e pertencimento público, tenho em consideração que a demarcação de distinções, posições, espaços de atuação e demandas é uma estratégia fundamental, desenvolvida pelos agentes engajados em contextos de conflito e luta social. O que se busca não é definir e, portanto, fixar a identidade dos movimentos sociais, mas sim, através de uma abordagem de caráter exploratório, apresentar elementos capazes de traçar aproximações e distanciamentos entre os diferentes modos de identificação enunciados por eventos acima descritos. Por isso, é importante ter em mente que estes modos de enunciação trabalhados são, antes de qualquer coisa, construções semânticas de caráter eminentemente político-reivindicatório, estes narrativas foram lançadas "para fora”, para o público. Assim, essas elaborações não se referem, necessariamente, às construções simbólicas utilizadas no desenrolar da língua e vida cotidiana, mas alocam-se em uma outra ordem do discurso.

Não obstante a enorme diferenciação interna nos chamados movimentos de luta por moradia da região central, a diversidade de suas nomenclaturas, reivindicações, modos de atuação e formas organizativas, é preciso ter em conta que o discurso sobre a casa aparece como uma importante referência na constituição pública e política destes. Obviamente esta referência aparece sob nomes distintos: vinculando-se aos cortiços, ao teto, ou à idéia mais 
geral de moradia. Nomes que aparecem nas próprias titulações dos movimentos: Unificação das Lutas de Cortiço, Fórum dos Cortiços, Movimento dos Sem-Teto do Centro (MSTC) e Movimento de Moradia do Centro (MMC). Deste modo, pode-se afirmar que estas diferentes formas de organização possuem a problemática habitacional como principal eixo reivindicativo. Assim, a idéia de casa é apresentada como horizonte reivindicatório e ponto de referência comum.

Nas manifestações descritas, tanto os movimentos de luta por moradia, quanto o Movimento da População de Rua, apresentavam-se como agentes que reivindicavam publicamente políticas sociais voltadas à temática habitacional. Ambos os movimentos encenaram uma luta em torno do direito à moradia digna para os mais pobres do Centro. Temática esta que parece constituir um solo comum de demandas para os dois tipos de movimento. Apesar desta semelhança, o MNPR carrega a rua como diferença irredutível, um signo que denota a ausência da casa, mas que também carrega consigo outras ausências e carências supostas. Isto, pois a rua é publicamente reconhecida como um espaço indigno para se dormir, trabalhar e viver. Os órgãos públicos com os quais o MNPR tenta travar interlocução extrapolam a esfera habitacional, encontrando referências em outros campos de ação, como justiça, saúde, trabalho, educação e, principalmente, assistência social. Deste modo, o arco de reivindicações proposto pelo MNPR, apesar de conectar-se com as demandas dos movimentos populares de moradia do Centro, não se restringe ao tema da habitação.

Assim, vemos que apesar de ambos os tipos de movimento lutarem por uma redistribuição dos recursos relacionados à temática habitacional, os modos distintos de reconhecimento nos quais estão envolvidos articulam-se à especificidade das demandas pelas quais se engajam. Um modo mais simples de interpretar estas diferenças - presentes nos processos de luta pelo reconhecimento e redistribuição nos quais os dois tipos de movimento estão engajados - poderia ser através de uma conexão analítica entre os dois signos diacríticos rua-casa. Este eixo, ao mesmo tempo em que afirma uma diferença entre os termos, também expõe uma desigualdade valorativa. De um lado, os atores vinculados discursivamente ao signo rua são marcados por uma maior carência e vulnerabilidade, tanto no que se refere à precariedade dos laços familiares, domiciliares e com o mundo do trabalho, quanto à corrente atribuição dada à fragilidade de suas condições subjetivas e corporais ${ }^{69}$. Do outro lado, os

\footnotetext{
${ }^{69}$ É assinalável que este último aspecto comentado - a fragilidade e a desorganização pessoal de modo mais amplo - compareça em algumas explicações elaboradas por certas lideranças dos movimentos de moradia, como justificativa para suposta incapacidade de organização política da população de rua e, portanto para a impossibilidade de ação conjunta com o MNPR. E isto pôde ser observado em momentos distintos da pesquisa. Contudo, o comentário que ouvi de uma liderança do MNPR resume um pouco esta questão: "os movimentos de
} 
atores populares vinculados politicamente em torno da temática da moradia, seriam considerados mais organizados, articulados e teriam a unidade familiar - ou o discurso sobre esta - como importante referência positiva. Assim, veríamos como a relação rua-casa também está pautada por um tipo de desigualdade valorativa, nos quais os associados ao primeiro termo seriam vistos como mais desorganizados e frágeis, enquanto àqueles vinculados ao segundo termo se apresentariam com mais organizados e politicamente articulados.

Este eixo também ajudaria a desconstruir alguns discursos que estabelecem equivalências diretas entre os sem-teto e os moradores de rua. Um dos motes desta indiferenciação é a apropriação da categoria estrangeira homeless. Esta categoria foi definida pelas Nações Unidas como, não só aqueles que vivem na rua, mas também os que estão em residências que não atendem à necessidade e aos padrões mínimos de habitabilidade. Deste modo, a cidade de São Paulo teria mais de 4 milhões de homeless (Rosa, 2005). A categoria homeless é consequentemente mais ampla e embaraça importantes diferenciações no que se refere aos modos pelos quais estes movimentos sociais enunciam publicamente suas demandas, a si mesmos e, portanto, suas especificidades enquanto sujeitos políticos. Vemos que esta indiferenciação das categorias aponta, justamente, para a questão comum que as engloba: a temática habitacional.

Meu argumento é simplesmente que a fronteira política e classificatória entre os movimentos de moradia do Centro e o Movimento da População de Rua (MNPR) pode ser explorada no interior de um espectro de diferenças contínuas que possui como operador analítico o eixo casa-rua. Esta conexão diferencial só pode ser concebida como um esquema nos quais os pólos extremos se materializam enquanto ideais-tipos, sendo que para isso seria necessário pensar a casa e a rua não só como lugares de moradia, mas também como espaços de enunciação coletiva, a partir dos quais os atores estariam necessariamente atrelados em suas lutas por conhecimento e redistribuição. Obviamente, entre estas categorias existe uma enorme continuidade e circularidade de pessoas, interesses e ações. Também, no interior do MNPR, bem como nos variados movimentos de moradia do Centro, existem importantes distinções e variações de demandas, mas o eixo casa-rua, devido ao seu aspecto ideal, só pode ser assim pensado quando conjugado através do tema da luta pela habitação ${ }^{70}$.

moradia não querem papo com a gente. Eles acham que a população de rua é tudo gente suja, barbuda, bêbada e que não sabe o que quer". Independentemente do caráter (efetivo ou não) destas formulações discursivas, é importante atentar para o fato de que, entre os grupos populares organizados da região central, também se operam clivagens e desigualdades pautadas por hierarquias classificatórias, valorativas e, também, estigmatizantes.

${ }^{70}$ Outra forma de complicar ainda mais este quadro um tanto esquemático é pensar o eixo casa-rua como um espectro diferencial atrelado às próprias relações de gênero. Assim, daríamos mais atenção para a maciça 
Por sua vez, a relação com o Movimento dos Catadores (MNCR) remete à outra temática social, esta agora vinculada ao universo do trabalho, mas não a todo este universo, e sim um tipo de trabalho específico desenvolvido na rua e com o lixo. Uma das principais bandeiras de luta deste movimento é o reconhecimento dos catadores como uma categoria profissional, já que são acusados como "coisa fora de lugar" ao ocuparem o espaço público da cidade e lidarem diretamente com um material sujo e poluente. $\mathrm{O}$ fato de não serem considerados como uma categoria profissional pelas instâncias legais dificulta ainda mais sua luta por reconhecimento, pois torna possível a constante apreensão de carroças e a decorrente expulsão destes trabalhadores pela ação dos diferentes agentes disciplinadores dos espaços públicos, tais como policiais, fiscais da prefeitura e limpeza urbana. Esta constante "perseguição" das autoridades urbanas - como foi denunciado em vários rituais-, é um solo comum de reivindicações entre o MNCR e o MNPR, mas também é aquilo que rasura suas fronteiras.

Em todos os eventos narrados, as imagens da população de rua e dos catadores se faziam presentes e se entrelaçaram de diversas maneiras. Algumas vezes como personagens distintos, porém aliados. Já em outros momentos, apareciam como coletividades de difícil dissociação. Contudo, uma diferença é que as reivindicações do MNCR orientam-se fundamentalmente em torno da prática da catação, tanto na luta pelo reconhecimento do tipo de atividade que desempenham, quanto ao direito ao uso do espaço público. Por outro lado, este último tema articula-se diretamente com uma das reivindicações do MNPR, que luta para que as pessoas que se encontram pernoitando nas ruas não sejam expulsas pelos agentes disciplinadores do espaço público, os mesmos agentes que também atuam sobre a categoria dos catadores. Entretanto, mais uma vez, nota-se que o campo de reivindicações do MNCR é muito mais amplo que aquele proposto pelo MNPR.

Como ambos os movimentos nasceram no interior de um mesmo campo social atravessado por entidades religiosas, organizações não governamentais e projetos diferenciados de atenuação da precariedade e apoio às vidas ligadas à rua e ao lixo -, parece ser mais produtivo tratá-los como inseridos num crescente processo de diferenciação inconcluso e não como alteridades políticas distintas. No entanto, as duas categorias em questão são alvos de acusações públicas, já que se relacionam prioritariamente com formas simbólicas distintas e marcadas pelo estigma, dois signos balizados pelo risco: o lixo e a rua.

presença feminina nos movimentos de moradia (sem falar que boa parte de suas lideranças também são mulheres), em relação à esmagadora maioria masculina daquilo que constitui a população de rua, bem como as lideranças do seu recém formado movimento social. Deste modo, juntamente como o eixo casa-rua, poderíamos articular outro, como feminino-masculino. 
Ocorre que os dois movimentos, ao terem objetivos diferenciados de luta política, desenvolvem estratégias distintas de manejo destes símbolos, exercendo uma verdadeira manipulação da identidade deteriorada (Goffman, 1988). E neste processo, mobilizam significados outros, operando torções de sentido com o intuito de construir atributos positivos para sua auto-imagem.

Vimos, nos rituais políticos, como o significado da atividade que define os catadores foi contestado. Isto ocorreu através de uma resemantização daquele material com que trabalham e, portanto, se associam. Assim, como estratégia de reconhecimento público, o discurso do MNCR buscou efetuar um deslocamento semântico sobre o lixo. Gritavam: "lixo não é lixo”. E neste processo tentavam purificá-lo simbolicamente, tirando dele toda carga negativa: poluição, contágio, sujeira e impurezas. Passaram a falar, então, em termos de material reciclável, um assunto que traz à cena não mais o risco e sim a segurança. Falar de reciclagem hoje em dia implica em se conectar com uma série de outros termos e objetos, tais como: natureza, economia de recursos e qualidade de vida. Ao trocar de aliado, do lixo para o material reciclável, do risco para a segurança, a figura do catador consegue desvencilhar-se discursivamente de possíveis impurezas semânticas e atribuir para si positividades antes desconhecidas. Incorporando os atributos deste material mais "puro" e "seguro", o catador consegue produzir um importante ponto de referência na luta pelo reconhecimento de sua atividade além de, também, possibilitar a construção de um orgulho próprio: "o catador é um agente ambiental", "é um trabalhador que ajuda a cidade". Essas são as sentenças, proferidas em aparições públicas espetaculares.

Assim, podemos ver como a partir de um solo histórico comum, tendo o centro de São Paulo como importante referência, o MNCR desenvolve uma trajetória que, pouco a pouco, se distancia do MNPR. Processo este no qual cada vez mais se caracteriza por estar gradativamente se afastando discursivamente de seu contexto de origem, marcado pela rua e pelo lixo, mediante a seleção e manipulação de símbolos que o associe e o identifique ao trabalho e à preservação do meio ambiente. Signos publicamente reconhecidos e que permitem aprovação. Obviamente, este processo sociopolítico de reversão de estigma e produção da diferença produz reações das mais diversas. Da boca de lideranças, cheguei a ouvir sentenças que evocam alguns dos modos pela qual a diferença é afirmada: "catador é catador, e, população de rua é população de rua”. Mas também escutei, mais de uma vez, da boca de algumas lideranças do MNPR: "os catadores costumam esquecer de onde eles vieram. E eles vieram foi da rua". O signo rua é utilizado aqui como principal liga e ponto de contato entre os dois movimentos, em seus entrecruzados processos de identificação. 


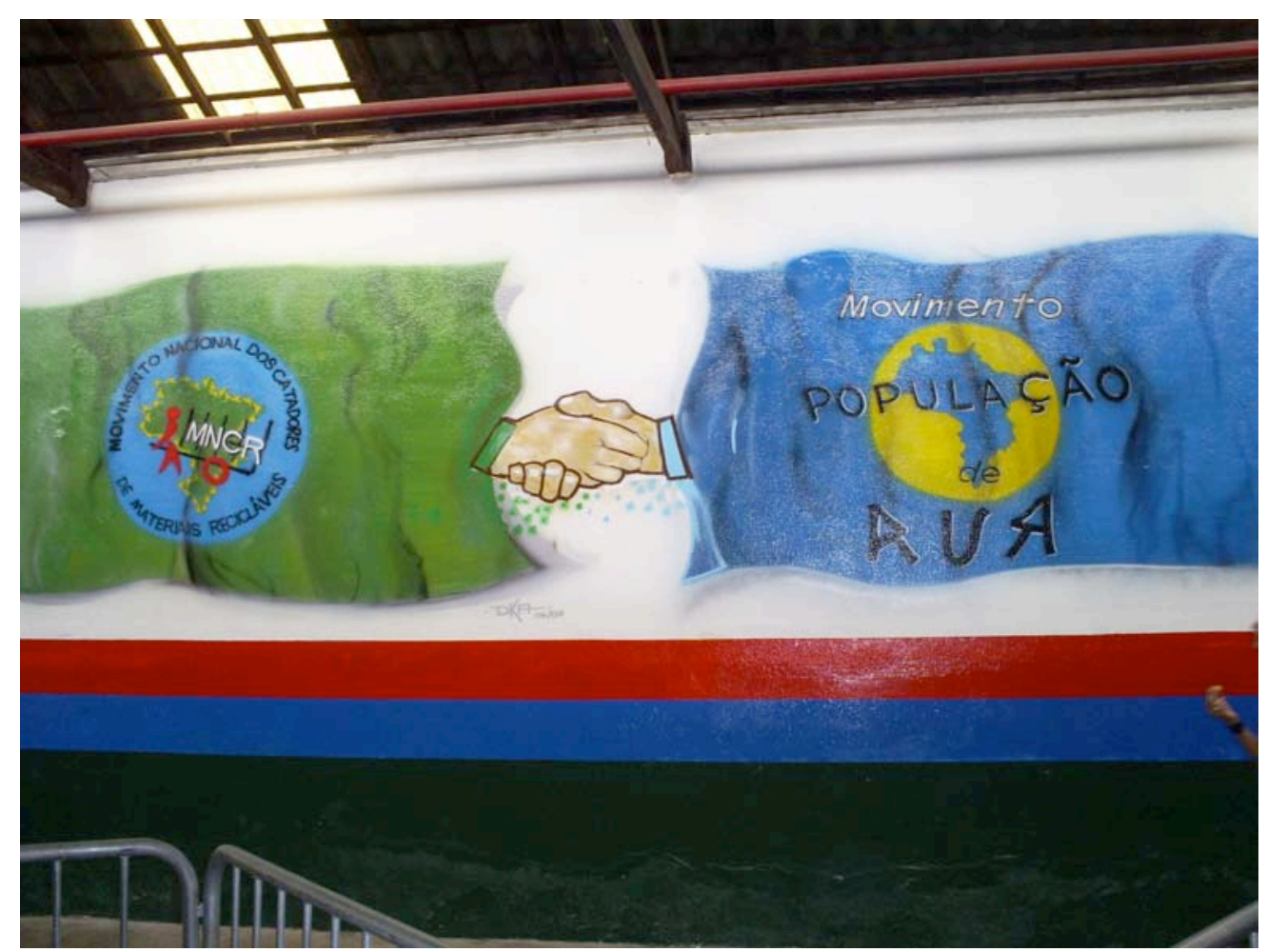

A aliança entre o Movimento dos Catadores e da População de Rua e suas respectivas bandeiras.

Pintura localizada no interior do Galpão do Projeto Cata Sampa, na Baixada do Glicério Foto: Daniel De Lucca Reis Costa

É este mesmo signo que funciona como eixo diacrítico e nó capaz de amarrar uma multiplicidade de percursos heterogêneos e experiências de vida variadas com as quais o movimento da população de rua tem de se haver, na construção de suas demandas e representações políticas. Contudo, esta referência simbólica, mesmo que saturada de negatividade, não pode ser facilmente descartada. Principalmente, se levarmos em consideração que o significado do signo cultural não é objeto completo de um ator, mas sempre atribuído "em parte pelo campo social ao qual está incorporado e pelas práticas as quais se articula e é chamado a ressoar" (Hall, 258:2003). Em verdade, construir a rua como um signo que baliza um tipo de experiência e desigualdade social (o sofredor de rua, o povo da rua, o morador de rua, a população de rua) em oposição a todas as outras formas pejorativas e individuais de designação (o mendigo, o vagabundo, o andarilho, o pedinte) foi, por si só, resultado de um intenso trabalho histórico de mediação e tradução, efetuado através de diversas práticas moleculares entrecruzadas e itinerários de lutas por reconhecimento, no qual vários outros agentes envolveram-se. Mesmo assim, permanece a pergunta: como o MNPR, ao buscar positividade para si mesmo e construir uma imagem passível de reconhecimento, lida com este signo marcado pelo estigma. 
Ao que tudo indica, parece haver um investimento ambíguo sobre o signo da rua. Por um lado, o estigma é retificado: "O Povo da rua não merece sofrer", frase declarada e proclamada na paisagem do Centro. Através desta sentença, reafirma-se aquele discurso construído historicamente e que caracteriza a experiência a rua como lugar de carência, sofrimento e dor. E este reconhecido sofrimento é justamente aquilo que legitima publicamente a luta política pela proteção e segurança destas pessoas. Por outro lado, algumas das afirmações evocadas nas mobilizações, sugerem uma tentativa de reabilitação do mesmo signo, tratando a rua também como um lugar de potência, criação e experiência única: "Morador de rua não é marginal, é gente que cria e inventa", frase enunciada nas manifestações e lançada ao espaço público da cidade. Nesta sentença, a rua não é unicamente como espaço de ausência e carência, mas também de presença e inventividade. De um lugar marcado pela dor e miséria, a rua aqui se transfigura, ainda que liminarmente, em um lugar de vida e "onde pessoas fazem diferente".

Nestes enunciados, foi possível vislumbrar a ambigüidade semântica atribuída ao signo rua, seu aspecto negativo e positivo. Como Jano, a rua adquiriu nestas manifestações duas faces - a morte e a vida, a destruição e a criação -, possibilitando extrair, de cada uma destas, uma eficácia e vigor específico. Lembremos que a memória do "massacre da população de rua" não só possibilitou o nascimento no MNPR, mas também serviu justamente para se gritar: "somos um povo que quer viver". Apesar de tudo, parece que esta bifacialidade do signo rua tende para um de seus pólos mais sombrios, sendo que apenas em certos momentos de ebulição, é que seu outro emerge com mais fulgor e presença. Mas a ambigüidade permanece irresoluta, não se resolve, já que ambos os discursos são acionados performaticamente ora um, ora outro, ou então juntos. Esta ambigüidade, ao mesmo tempo em que embaraça as certezas, também potencializa sua eficácia estratégica e discursiva do próprio movimento.

A questão não é se este modo ambivalente de identificação servirá ou não como horizonte político e reivindicatório, mas sim ter em conta que ele já está sendo agenciado como tal. O desafio maior seria interpretar as formas pelas quais isto é feito. Também esta ambigüidade não pode ser compreendida como uma relação impeditiva, pois, até onde foi possível explorar, ela é, muito mais, um elemento constitutivo do movimento. Esta identificação, a princípio problemática, do discurso da população de rua, reproduz-se na ambivalência do próprio movimento social, que recentemente surgiu para buscar representála. Ao mesmo tempo em que o MNPR luta para que se construam possibilidades de saída das ruas, o mesmo tem de lidar com uma outra frente de problemas: aquela que diz respeito aos 
embates diários e às lutas para que inúmeras pessoas - que cotidianamente se tornam objeto de violência e intervenções locais, por agentes legais, mas também ilegais - tenham, no mínimo, o direito à rua.

Talvez seja nesta ambigüidade que resida a diferença deste movimento social. No coração do reconhecimento de que a rua é um espaço indigno de vida, reside a necessidade da afirmação de que este espaço seja tolerado ao menos como lugar de vida para um amplo contingente de pessoas que diariamente é deslocado, retirado, expulso e incitado à mobilidade contínua pelos interstícios da cidade. Este jogo agonístico, nos termos que a luta política pelos direitos da população de rua se coloca, é a própria condição paradoxal desta luta. A potência de seu discurso reivindicatório provém deste reconhecimento da dificuldade em encontrar saídas efetivas para um problema trabalhosamente identificado e que parece ter suas causas espalhadas por todos os lados. Esta dispersão da causalidade é justamente aquilo que produz uma dispersão nas próprias demandas reivindicativas do Movimento da População de Rua (MNPR), mas também é aquilo que acompanha a inabilidade dispersa dos poderes públicos, outras autoridades responsáveis e um conjunto mais amplo de atores e instituições, em construir formas de seguridade e possibilidades de proteção social adequadas e toleradas. É esta dispersão em rede, dos modos de segurança e proteção, que pretendo analisar no próximo capítulo. 


\section{Capítulo III: Rede de proteção, albergue e seus usos}

Este capítulo visa contribuir parcialmente para a compreensão dos mecanismos institucionais pelos quais a população de rua é regulada enquanto um problema de gestão e segurança, tendo como principal referência a experiência albergal. No início deste capítulo, pretendo apresentar rapidamente a atual composição da rede de atendimento à população de rua, buscando ressaltar o papel desempenhado pelo albergue como peça fundamental nesta composição. Num segundo momento, descrevo mais detalhadamente uma etnografia do interior de um albergue pontuando o contexto urbano em que este se situa, as condições na qual a etnografia foi feita e analisando certos aspectos da dinâmica cotidiana na instituição e do funcionamento da rede de atendimento. Na última parte do capítulo discorro sucintamente sobre alguns dos efeitos do sistema albergal, bem como suas possíveis dimensões securitárias.

\subsection{Rede de atendimento e proteção social}

São Paulo é hoje a principal referência nacional sobre o fenômeno população de rua. No decorrer dos anos, acumulou um considerável conhecimento sobre o tema, desenvolveu um conjunto de práticas e intervenções políticas que, bem ou mal, se tornaram num modelo. Este processo resultou na constituição de uma ampla rede de assistência e atendimento à população de rua, experiência única em todo país. Tal rede iniciou-se pontualmente, a partir das casas de convivência, e, no decorrer da década de noventa, foi se diversificando, se estendendo, ganhando outros componentes, novos procedimentos e funções. Tais técnicas e formas especializadas de tratamento foram historicamente experimentadas e testadas. Não foram simplesmente inventadas do nada, não preexistiram à intensa avaliação, negociação e intercâmbio. Foram se articulando e se ampliando através de linhas entrecruzadas, se conectando a uma teia de procedimentos um pouco mais consistentes e interligados, dando forma a este dispositivo de segurança. Neste processo, algumas destas práticas e saberes localizados - que até então se desenrolavam em temporalidades mais ou menos disjuntivas e com finalidades diferenciadas umas em relação às outras - foram sendo incorporados, alguns descartados, outros reapropriados e ajustados em relação a um mesmo e complexo objetivo comum: a proteção social da população de rua.

Contudo, o efetivo fortalecimento, instalação e consolidação desta rede de procedimentos se deu em 2001, com a regulamentação da Lei de Atenção à População de Rua 
e a decorrente definição jurídica de seus objetivos. Esta lei foi resultado de quase uma década de discussões e trocas de experiências entre as organizações que trabalham com este público e outros agentes sociais. No corpo da lei, se consubstanciam alguns dos princípios que orientam os procedimentos da rede, e, por conseguinte, expõem certa concepção sobre a experiência de rua e a população de indivíduos que a vivenciam. Vejamos alguns de seus pontos.

A Lei n. 12.316/97, que visa "garantir os padrões éticos de dignidade e não violência na concretização de mínimos sociais" (SAS, 2001:7), tem como um de seus princípios "restabelecer sua dignidade, autonomia, bem como sua convivência comunitária" (SAS, 2001:8). Entre outras coisas contempla: abrigos emergenciais para acolhida, sobretudo no inverno; albergues "com instalações adequadas, equipados, com recursos humanos e materiais necessários à acolhida e alojamento de até 100 pessoas por unidade operacionalizados diretamente ou em parceria com organizações sociais" (SAS, 2001:21); restaurantes comunitários com oferta diária de alimentação em baixo custo; casas de convivência; moradias provisórias para moradores de rua em "processo de reinserção social" (SAS, 2001:24); soluções habitacionais definitivas, sob responsabilidade da Secretaria Municipal de Habitação, que atendam também pessoas com maior grau de autonomia, auxílio à moradia e construções em regime de mutirão; oficinas, cooperativas de trabalho e comunidades produtivas; projetos sociais com pedagogia de rua; uma reserva do orçamento municipal para fazer cumprir a lei; e a publicação de um censo anual da população de rua.

No corpo da lei, todos estes elementos são acompanhados por maiores detalhes em relação aos padrões de procedimento adequados a cada tipo de serviço prestado, suas normas de higiene, qualidade de recursos materiais e humanos, bem como informações pormenorizadas sobre a flexibilidade ou não de determinadas regras, espaços, horários e modos de atendimento. O que se tem então é uma regulamentação que, não só obriga o poder público a articular - por meio de orçamentos, supervisões e reavaliações dos convênios e parcerias - os diferentes serviços prestados, mas que também imprime modelos de relações que tanto os usuários, quanto os funcionários, devem observar em suas atividades rotineiras. Uma das idéias presentes na lei, e que orienta os modos de atuação na rede, é que os tipos de serviços prestados devem acompanhar o grau de autonomia dos usuários e as diferentes etapas do processo de reinserção social. Estas duas idéias estão articuladas por outra: a de tempo de rua. Deste modo, quanto mais autônoma e inserida socialmente a pessoa, mas distante da rua ela deve, ou deveria, se encontrar. Vemos aqui que a lei e a rede de atendimento - cuja regulamentação é apenas uma resultante parcial, provisória e mais recente 
de um processo ainda em andamento - carregam consigo a premissa de que é inconcebível que alguém esteja habitando as ruas da cidade.

Apesar da diversificação das políticas e serviços supostos nesta lei, hoje a rede de atendimento é composta apenas por uma parcela destes, mas também é composta por outros serviços que estão em andamento e que não foram previstos legalmente. Ou seja, se é verdade que parte da lei está sendo descumprida, também é verdade que inúmeras outras atividades não codificadas por esta se encontram em andamento, sendo que algumas destas atividades de auxílio e assistência são desenvolvidas por grupos e organizações sequer articuladas ao poder público municipal. O reconhecimento da existência de outras ações voltadas a esta população já permite vislumbrar que complementarmente à rede oficial, codificada e conectada aos aparelhos do Estado, coexistem e articulam-se outras modalidades de serviços e procedimentos mais informais, das quais os praticantes destas relações podem também usufruir e circular.

Contudo, estas outras experiências permanecem como referências secundárias em relação à predominância do circuito institucional de atendimento, sendo que os elementos mais importantes deste são: os albergues, os núcleos de serviços e de convivência, as moradias provisórias e algumas cooperativas ${ }^{71}$. Todos estes serviços são resultados de convênios da Secretaria Municipal de Assistência e Desenvolvimento Social (SMADS) com organizações não governamentais, em boa parte, ligadas a igrejas. Além disso, outros dois importantes elementos, que foram adquiridos mais recentemente na gestão Marta (PT, 20012004), também compõem esta rede, desempenhando a função estratégica de integrar, de modo mais eficaz, os diferentes serviços prestados: a CAPE e o SISRUA. A Central de Atendimento Permanente (CAPE) é um sistema de transporte composto por Kombis que podem ser acionadas para recolher e encaminhar usuários e moradores de rua para outros serviços, albergues, hospitais ou clínicas psiquiátricas. Já o Sistema Integrado de Informações da População de Rua (SISRUA) é um sistema computadorizado, conectado à quase todos os

\footnotetext{
${ }^{71}$ As informações, que compõem o cenário aqui apresentado, são resultantes de um corpus de dados extraídos de documentos, seminários, entrevistas, conversas, visitas e etnografias em alguns pontos desta rede. As informações mais específicas sobre a quantidade numérica dos atuais equipamentos da rede foram extraídas de uma pequena cartilha (SMADS, 2006), que a prefeitura passou a distribuir no começo de 2007. Esta cartilha é um guia para o usuário da rede, apresentando o endereço e a especificidade de todos os serviços existentes. Esta prática, de distribuir guias de serviços, foi inaugurada com a gestão Marta. Contudo, é importante salientar que as informações numéricas mais recentes são provisórias, pois um caráter próprio ao funcionamento desta rede é sua, aparentemente, ininterrupta transformação. Desde sua conformação inicial, muitos dos serviços e procedimentos institucionais foram alterados. Através do trabalho de campo em vários equipamentos, pude ver como a dinâmica desta rede e as regras práticas que a regem são extremamente fluidas e instáveis, sofrendo alterações por disputas e desentendimentos cotidianos, que permanentemente colocam e recolocam em cheque vários de seus procedimentos rotineiros.
} 
equipamentos da rede, e, cuja função, é cadastrar e permitir um melhor acúmulo e circulação de informações sobre os indivíduos que compõem esta população, bem como sobre os procedimentos e encaminhamentos efetuados pelos funcionários e assistentes sociais.

A grande maioria dos equipamentos e serviços da rede adensa-se no centro da cidade, sobretudo nas regiões administradas pelas subprefeituras Sé e Mooca, onde também se encontra a maior concentração de moradores de rua e de catadores de materiais recicláveis em São Paulo. No caso das cooperativas de catadores do Centro, são poucos os convênios existentes com a Secretaria Municipal de Assistência Social, sendo que um dos atuais focos de conflitos e controvérsia é sobre a possível alteração do tipo de relação estabelecida com a prefeitura $^{72}$.

Já as moradias provisórias são modalidades diferenciadas de habitação para esta população, espécies de residências coletivas, em regime de república, voltadas especialmente para pessoas com um maior grau de autonomia. Esta maior "autonomia" é mormente requerida, pois seus usuários têm de apresentar um conjunto de capacidades e hábitos mais ajustados à dinâmica interna da república: arrumando e limpando a casa, comprando a sua própria comida e cozinhando-a, e, mais importante, convivendo coletivamente com os outros residentes. Apesar de serem conveniadas com a SMADS e coordenadas por organizações sociais, seus usuários necessitam pagar mensalmente um fundo de moradia, que varia entre $\mathrm{R} \$ 30$ e $\mathrm{R} \$ 50$, e é revertido para manutenção da casa. Por isso é cobrado, antes da entrada, que o candidato desenvolva algum trabalho ou fonte de renda, ainda que mínima, para conseguir cumprir o pagamento do fundo de moradia, mas também seus próprios custos. As primeiras moradias provisórias foram desenvolvidas pela OAF, fruto das "moradias comunitárias" da Baixada do Glicério, e transformaram-se em política pública focal para a população de rua, sobretudo, na gestão municipal do PT (2001-2004). Mesmo possuindo pouca expressividade numérica no interior da rede, este é um equipamento de grande procura pelos usuários.

Hoje, mais da metade dos albergues instalados na rede funciona também como núcleo de serviços durante o dia. Contudo, nem todos os núcleos de serviços funcionam no mesmo

\footnotetext{
${ }^{72}$ Desde o primeiro convênio estabelecido entre um governo municipal (no caso, a gestão Erundina) e uma cooperativa (no caso, a Coopamare), já se questionava se este tipo de relação deveria ou não ser mediado por uma secretaria da assistência social. Implícita a esta dúvida, apresenta-se a interrogação sobre se os catadores devem ser interpretados como uma categoria profissional ou como uma categoria de assistidos. Hoje, esta questão está recolocada, sendo que a proposta é que a relação das cooperativas com a prefeitura seja mediada pela Secretaria de Serviços e Obras. Tal alteração, entretanto, ainda está em trâmite e é mais um dos pontos de desentendimentos entre a atual gestão municipal (PSDB-PFL) e o Movimento dos Catadores (MNCR). A principal crítica do MNCR em relação a esta alteração institucional é que, se a atividade destes trabalhadores for colocada unicamente em termos de economia e infra-estrutura urbana, muitos catadores, que, apesar de serem cooperados, se encontram em situação precária e vivendo nas ruas, perderão seu ganha pão devido à competitividade que poderá se instalar.
} 
espaço que os albergues, muitos possuem um lugar próprio. Este tipo de serviço é tributário das antigas casas de convivência e só mais recentemente é que adquiriram este nome. Estes núcleos são lugares onde se pode usar alguns serviços ligados à reprodução pessoal, tais como: refeitório, banheiro, chuveiro, tanques de lavar roupa, mas também atendimento com algum profissional do serviço social e, em alguns casos, enfermaria ou ambulatório. Já outros, destes núcleos, desenvolvem mais fortemente certas práticas de convivência coletiva, como: dinâmicas de grupo, cursos de alfabetização e de arte, atividades ocupacionais, educacionais e de lazer. Também permitem recorrer a serviços de documentação, referências na cidade e encaminhamento médico, psiquiátrico ou psicológico. Apesar de importantes, os núcleos de serviços configuram uma peça institucional complementar ao albergue no cotidiano da rede e daqueles que por ela circulam.

De todos os albergues existentes na rede, apenas um não é conveniado com a prefeitura e sim com o governo estadual. Este albergue, o Arsenal, é o maior da cidade, com 1.200 pessoas, e localiza-se num antigo sítio urbano de segregação e quarentena, a Hospedaria do Migrante. Este espaço institucional, que historicamente foi voltado para o controle do fluxo de trabalhadores migrantes na cidade de São Paulo, no final da década de oitenta começou a ganhar outros usos e atribuições, sendo que no decorrer da década de noventa institucionalizou-se enquanto espaço próprio à população de rua. Apesar da forma instituiçãoalbergue ser um espaço já conhecido na história paulistana e brasileira, me parece que há algo de inaugural e inventivo em sua trajetória mais recente. Isso porque ao ganhar novos usos e usuários, esta instituição também foi adquirindo outra funcionalidade, especializando-se e integrando-se, mais e mais, ao conjunto de práticas de assistência, acolhimento e proteção da população de rua. Sendo que só mais recentemente é que passou a constituir-se como uma instituição específica para este público-alvo ${ }^{73}$.

O albergue, legalmente, possui como função abrigar as pessoas que não têm onde passar a noite, sendo que a maioria deles oferece jantar e café da manhã. Durante a última década, constituíram-se como importantes reivindicações das entidades às gestões municipais Maluf (1993-1996) e Pitta (1997-2000). Muitos albergues surgiram - e ainda surgem - em meio às operações de inverno, período em que se instauram abrigos emergenciais, de modo a

\footnotetext{
${ }^{73}$ Entrevistei um dos coordenadores do albergue Arsenal logo no início do trabalho de campo. Apresento-o aqui apenas com a intenção de apontar para a dimensão histórica destes espaços institucionais. Seria necessário, algum dia, se fazer uma arqueologia dos albergues. No primeiro capítulo, tentei acenar para alguns elementos mais pontuais que poderiam ajudar na compreensão de sua história. Uma história que deveria levar em conta sua transformação funcional e técnica, sua reapropriação pelo Estado, sua metamorfose em política pública focal, sua multiplicação, e os pelos quais foi sendo reconhecido e questionado como uma instituição eficaz para a gestão e proteção da população de rua na cidade de São Paulo.
} 
tentar proteger os moradores de rua do frio, um significativo causador de mortes entre eles. Contudo, mesmo com a abertura desses albergues emergenciais, em nenhum momento da história das últimas décadas, as instituições conseguiram abarcar o contingente populacional vulnerável às condições climáticas de tal estação (Frangella, 2004).

O número de albergues apresentou um aumento gradativo no decorrer dos anos noventa e, no início do novo século adquiriu uma importância fundamental na rede de atendimento à população de rua. Em 1992, eram apenas três, sendo que cada um deles possuía especificidades e funcionalidades distintas, não se integrando e, tampouco, se voltando prioritariamente ao contingente de pessoas que se encontrava nas ruas da cidade. Posteriormente, em 2001, esse número saltou para quatorze (Giorgetti, 2006). Hoje, sabe-se que o número de albergues ultrapassa os vinte e oito (SMADS, 2006). Contudo, a multiplicação dos albergues acompanha, também, o crescimento numérico do fenômeno população de rua, e esta relação fica mais exposta nas duas últimas contagens efetuadas pela FIPE, no período entre os anos 2000 e 2003:

\begin{tabular}{|l|l|l|l|l|}
\hline \multicolumn{5}{|c|}{ Contagens da população de rua e sua distribuição por local de pernoite } \\
\hline Ano & Logradouro & Albergue & Total & Gestão \\
\hline $\mathbf{1 9 9 1}$ & $3.392^{74}$ & & & Erundina \\
\hline $\mathbf{1 9 9 4}$ & 2.800 & 1.749 & 4.549 & Maluf \\
\hline $\mathbf{1 9 9 6}$ & 3.421 & 1.913 & 5.334 & Maluf \\
\hline $\mathbf{1 9 9 8}$ & 3.037 & 3.416 & 6.453 & Pitta \\
\hline $\mathbf{2 0 0 0}$ & 5.013 & 3.693 & 8.706 & Pitta \\
\hline $\mathbf{2 0 0 3}$ & 4.208 & 6.186 & 10.394 & Marta \\
\hline
\end{tabular}

Fontes:

Secretaria Municipal da Assistência Social (SAS)/Fundação Instituto de Pesquisas Econômica (FIPE), 2000 e 2003.

Entre os anos de 2000 e 2003, registrou-se um acréscimo de mais de duas mil pessoas em situação de rua, indo da cifra de 8.084 para a de 10.394 . Hoje se estima que sejam mais de 12.000. Contudo, é significativo que, nestas estatísticas, o que é considerado como população de rua inclui todos aqueles que se encontram nos albergues. Assim, as últimas contagens demonstram que o número das pessoas que se utilizam da rua como lugar de pernoite não

\footnotetext{
${ }^{74}$ Este número corresponde unicamente à população contada que se encontrava nos logradouros públicos, portanto os usuários dos equipamentos institucionais não foram aqui considerados. Vale dizer que, neste período de 1991, a prefeitura contava apenas com duas instituições do tipo albergue, uma que abrigava cerca de 200 pessoas e outra com capacidade para 300, além do antigo CETREN, com capacidade de atendimento de até 400 pessoas. Mesmo não sendo totalmente exatos estes números, já que foram extraídos de conversas com algumas pessoas que estavam envolvidas com este tema neste período, poderíamos afirmar que no ano de 1991 havia 3.392 pessoas pernoitando nas ruas, somadas a cerca de 900 em equipamentos públicos diversos, totalizando o número aproximado de 4.292 pessoas em situação de rua.
} 
aumentou, mas chegou a apresentar até uma pequena diminuição. O que parece ter aumentado, segundo a leitura dos algarismos acima expostos, é, sim, o número de pessoas que se utilizam do albergue e que entram no cômputo geral da categoria população de rua. Contudo, este significativo aumento dos usuários não é espantoso, se levarmos em consideração que na gestão Marta o número de vagas existentes nestas instituições praticamente dobrou. Portanto, a hipótese é de que há uma correspondência recíproca entre o crescimento da população de rua e a constituição de uma rede de serviços, cuja linha de toque pauta-se pela multiplicação dos albergues.

Nesta gestão foi lançado o Programa Acolher: Reconstruindo Vidas, que possuía, como eixo estruturante, três linhas de atendimento: a acolhida, o convívio e a autonomia. Este programa foi a principal vitrine nas políticas de assistência social na cidade durante este período e levou à construção do Projeto Oficina Boracéia, caracterizado como uma oficina de reconstrução de vidas e considerado exemplar pela gestão municipal. O caráter singular deste projeto - a extensa área ocupada, a ampla oferta de atendimentos, o alto número de vagas de pernoite, o elevado investimento público em seu planejamento e manutenção, e a participação de, pelo menos, duas outras secretarias municipais -, gerou grande repercussão pública, levando, inclusive, a uma visita do presidente Luiz Inácio Lula da Silva ao equipamento. Vale apenas comentar que, a inauguração deste projeto, bem como a instalação de vários outros albergues maiores na rede, fez com que a mesma prefeitura responsável pela regulamentação da lei a descumprisse em vários aspectos, mas principalmente no que se refere ao limite da capacidade máxima de cem pessoas por albergue.

$\mathrm{Na}$ atual gestão municipal (PSDB-PFL, 2005 em diante), há uma tendência à continuação dos projetos anteriores, inclusive no que se refere à multiplicação dos albergues e ao fato da política restringir-se unicamente à Secretaria da Assistência. Nesta alteração municipal, apesar do Projeto Acolher ter se transformado em Programa São Paulo Protege, as ações da atual Secretaria da Assistência (SMADS) ainda são pautadas pelas práticas da gestão precedente ${ }^{75}$. Permanecendo a política anterior de ampliação da rede, novos equipamentos e convênios foram abertos com organizações sociais que até então nunca haviam desenvolvido projetos com a população de rua. Este último fator é interpretado por

\footnotetext{
${ }^{75}$ Esta continuidade poderia ser atribuída a pelo menos dois elementos: um é que a Lei de Atenção codificou aquilo que seriam as bases comuns de uma política para a população de rua, dificultando, assim, possíveis mudanças bruscas nas práticas governamentais relacionadas ao tema; outro elemento que pode ter contribuído para esta forte continuidade, refere-se a uma explicação que eu mesmo ouvi em campo: em algumas das conversas com funcionários e assistentes sociais da rede, fiquei sabendo que a antiga secretária municipal da assistência, Aldaíza Spozati, foi professora do atual secretário, Floriano Pesaro. E nestas conversas, a causa da continuidade da política era atribuída ao fato de Pesaro reconhecer na gestão anterior de sua professora "um trabalho de qualidade" e que não deveria ser alterado significativamente.
} 
algumas entidades mais antigas como potencialmente prejudicial, pois a entrada de organizações e funcionários sem a capacitação adequada para o trabalho com este públicoalvo pode diminuir a qualidade dos diferentes serviços prestados na rede. A despeito de não pretender aqui desenvolver uma análise das políticas públicas efetuadas em relação à população de rua, vale comentar que a alteração dos governos municipais produziu pelo menos uma descontinuidade relevante no que se refere ao tema. Apesar de ser uma prática ainda inicial e pontual, a recente abertura de albergues e equipamentos para a população de rua nas regiões mais periféricas da cidade aponta para possíveis e importantes transformações no funcionamento desta rede, bem como novas formas de diálogo entre estes espaços institucionais e as especificidades das configurações territoriais em que passam a se situar ${ }^{76}$.

Embora esta rede tenha sofrido uma importante ampliação e diversificação de seus componentes na entrada do novo século - com a regulamentação da lei, a construção de um programa municipal específico para o tema e a crescente abertura de novas parcerias, convênios e equipamentos -, o modo como este conjunto de ações foi articulado, resultou na proliferação dos albergues, transformando-os na principal política pública para a população de rua na cidade de São Paulo. O que é mais notável, no entanto, é que desde o início da construção de uma política para população de rua, na gestão Erundina (PT, 1989-1992), a proposta de um atendimento pautado por grandes instituições capazes de fornecer alojamento e pernoite, já era colocada como um modelo improdutivo. No $1^{\mathrm{O}}$ Seminário Nacional sobre População de Rua, realizado no ano de 1992, as respostas institucionais à população de rua foram criticadas sob vários ângulos, sendo que o que se propunha na época eram experiências mais circunscritas de trabalho, em que através de práticas locais de caráter "comunitário" e

\footnotetext{
${ }^{76}$ Sabendo que a instituição albergue transformou-se numa estratégia de sobrevivência para um grande número de pobres no centro de São Paulo, a atual prefeitura (PSDB-PFL) tem instalado novos albergues em alguns espaços mais periféricos da cidade - como Ermelino Matarazzo, Vila Prudente e São Mateus. Segundo o coordenador de um albergue: "a prefeitura fez isso porque descobriu que muitos usuários vêm da periferia. Então ela quer que eles permaneçam na periferia e não venham para o Centro. Só que eles não querem nem ir para o albergue que fica na Barra Funda (Projeto Boracéia), aqui perto, imagina se eles vão querer ir para a periferia". Realmente, parece que a CAPE tem encontrado muita resistência para levar as pessoas que se encontram nas ruas do Centro para estes albergues mais distantes. Uma alegação comum é: "o lugar é longe pra caramba, se eu for para lá não tenho nem dinheiro para voltar para cá”, como explicou-me um albergado do Centro. Entretanto, aquilo que é rejeitado por alguns na região central, parece ser aceito de bom grado lá por estas bandas. Já se tem algumas informações sobre o tipo de público que estes equipamentos recebem, um público com características muito distintas do Centro, apesar de também serem notadamente marcados pela pobreza. Muitos de seus usuários vivem e possuem vínculos com o precário entorno, é gente desalojada, que perdeu o barraco, que procura emprego, jovens jurados de morte, famílias inteiras utilizando-se dos serviços possíveis, como refeições, banhos, encaminhamentos para hospitais e conversas com assistentes. Lá a demanda por serviços públicos é grande e qualquer equipamento instalado é bem vindo.
} 
espaços menores para a convivência e a troca, seria possível enfrentar as dificuldades vividas por esta população com uma maior eficácia do que nas grandes instituições ${ }^{77}$.

Hoje, devido ao tamanho dos equipamentos instalados e sua crescente informatização e tecnicização, a rede de proteção e serviços apresenta um atendimento de massa com uma forte tendência a uma maior institucionalização e racionalização de seus procedimentos. Vemos que a mesma lei que possibilitou a consolidação desta rede, também possibilitou a extensão de suas ligações e a abertura para a chegada de novos componentes, agentes, técnicas de informação, sistemas de transportes, funcionários e, mais que tudo, usuários. Resta saber se esta lei, com sua pesada normatização, codificação e detalhamento dos procedimentos devidos, consegue regular a multidão de novos agenciamentos que liberou e que circulam na rede que ela mesma ajudou a constituir.

\subsection{Experiência albergal}

Tentei mostrar acima a posição do albergue e sua importância no conjunto mais amplo da rede de atendimento à população de rua. Contudo, tal importância também se faz no próprio discurso elaborado sobre a experiência de rua. Em fóruns, seminários, debates e discursos públicos, a experiência institucional do albergue surge constantemente como um forte alvo de crítica, mas também como um poderoso eixo de reivindicação. Também no universo das ruas, o albergue aparece como uma forte referência tanto para aqueles que o rejeitam quanto para aqueles que o tomam como um horizonte tangível de uso. Foi partindo do reconhecimento de sua importância no imaginário sobre população de rua, mas também no imaginário daqueles que são colocados na posição de população de rua, que me decidi por fazer uma etnografia no interior do albergue.

A proposta inicial era, a partir de uma maior aproximação com os impasses e dramas diariamente vividos, compreender e analisar o próprio funcionamento da instituição - uma

\footnotetext{
${ }^{77}$ Estas formulações, que foram apresentadas em várias falas deste seminário, estão transcritas e presentes no livro organizado por Cleisa Maffei Rosa (1994) População de Rua: Brasil e Canadá. Comento aqui apenas um ponto que também me parece relevante: Aldaíza Spozati - ex-secretária da assistência social e uma das responsáveis pela considerável ampliação do número de albergues na cidade - participou diretamente deste seminário e uma de suas falas aponta justamente para uma crítica à tendência do tratamento institucional da população de rua. Segundo ela, precisaríamos "invadir a proposta institucional para configurá-la numa outra direção, direção que possa responder realmente às questões que estamos enfrentando”. (Sposati, 1992:161) Contudo, parece que, junto com o próprio o movimento da história, as opiniões das pessoas também mudam. Comento isto apenas para enfatizar a necessidade de se reconsiderar o suposto aspecto inelutável do processo de institucionalização no qual a população de rua foi sendo colocada na cidade de São Paulo. Um processo que foi atravessado por possibilidades de escolhas, caminhos e percursos, e que, por isso mesmo, poderia ter sido diferente.
} 
aproximação etnográfica que buscava explorar as dimensões internas do albergue. Ao dormir, comer e conviver por algum tempo com os usuários do albergue, busquei analisar os enlaces entre as dinâmicas institucionais, a vida cotidiana local e a experiência social de seus praticantes. Este método, de se "internar" por certo tempo numa dada instituição, assemelhase àquilo que foi feito por Erving Goffman (1974) em sua obra clássica Manicômios, Prisões e Conventos. No entanto, entre as instituições totais analisadas por Goffman e o albergue, há importante diferenças e semelhanças que no momento mais oportuno serão discutidas. Apesar de estar muito preocupado em entender como esta espécie de micro-segregação urbana articula-se com a vida de seus praticantes - tanto usuários quanto funcionários -, o foco analítico também se voltou às intersecções daquele espaço com outros.

Se for correto afirmar, como faz René Lourau, que a instituição é um cruzamento de instâncias e necessita ser pensada como atravessada por vários níveis de significação e planos de consistência, a análise institucional deve ser definida e operada precisamente em sua transversalidade. (Lourau, 2004) Deste modo, sabendo dos limites de uma análise institucional localizada e circunscrita, busquei transpor a experiência albergal enquanto espaço fechado e unidade isolada. Até porque uma das maiores especificidades desta instituição é a abertura para seu exterior, contudo, uma abertura controlada, regrada e mediada por procedimentos rituais. Assim, no desenrolar da pesquisa comecei a me esforçar por assentar esta experiência etnográfica do albergue no seio de feixes de relações com outros processos e mecanismos operantes na rede. Para isso ampliei meu trabalho de campo através de visitas a outros albergues e equipamentos que lidam com a população de rua. Nestas visitas, de diferentes maneiras efetuei observações, anotações, conversas e escutas.

Nesta segunda seção do capítulo, pretendo apresentar a experiência etnográfica do albergue tendo em conta o diagrama mais amplo de relações em que esta se situa. Devido à quantidade de material coletado em campo, o texto está organizado por temáticas e cenas descritivas que me pareceram relevantes para o entendimento de um certo conjunto de relações dinâmicas. Num primeiro momento, começo com uma apresentação mais circunscrita do contexto urbano e institucional em que a etnografia foi desenvolvida e, posteriormente, no decorrer do texto, serão abertas outras linhas que permitirão vislumbrar certas facetas do funcionamento desta rede em suas variadas utilizações. Conseqüentemente, apresento adiante o movimento de um texto que se insinua local, para alcançar o traçado de conexões entre diferentes situações e lugares. 


\subsubsection{Contexto urbano e etnográfico}

O albergue São João ${ }^{78}$ localiza-se debaixo de um viaduto da Baixada do Glicério, justamente onde, até o início da década de oitenta, funcionava um terminal rodoviário. Posteriormente este terminal foi invadido e utilizado como moradia e habitação. A ocupação dos cômodos do antigo terminal chamou a atenção dos jornalistas da época, quando então foi noticiada uma série de reportagens sobre a Baixada do Glicério e seus peculiares tipos humanos (Rosa, 2005). Houve reação do poder público, que interferiu no local, esvaziando-o para a construção de um albergue para a população de rua. Atualmente a Baixada do Glicério continua sendo importante referência para os habitantes de rua na cidade de São Paulo que se constitui como um território diferenciado, visto que é uma designação topográfica popular sem qualquer referência formal ou consagração oficial. O Glicério não é um distrito, tampouco uma região administrativa da prefeitura. Situa-se num espaço urbano incrustado nas bordas de três distritos centrais: Sé, Cambuci e Liberdade. Contudo, notadamente o Glicério é um bairro conhecido e reconhecido por todos que ali vivem. Historicamente foi uma região pantanosa, área de inundação e várzea do Rio Tamanduateí, sendo que as enchentes que durante todo o século XX assolaram o bairro só foram diminuir na década de 1990, quando a prefeitura fez algumas reformas na calha do rio.

Hoje, o Glicério pode ser entendido como mais um daqueles lugares difíceis de descrever e de pensar devido a sua centralidade em certos discursos midiáticos e de poder. Não à toa, é reconhecido pelas autoridades municipais como um "bairro problema". Lá há um enorme adensamento de cortiços, pensões, moradores de rua, catadores, cooperativas, depósitos clandestinos de materiais recicláveis e intensa atividade do tráfico de drogas. Assim, o Glicério é foco de uma série de investimentos urbanísticos, policialescos e assistenciais de qualificação, reabilitação e reforma social, além de apresentar uma grande concentração de atividades do terceiro setor, organizações não governamentais, entidades filantrópicas, religiosas e projetos sociais ${ }^{79}$.

\footnotetext{
${ }^{78} \mathrm{O}$ nome da instituição foi alterado para não expor seus funcionários, usuários e mantenedores.

79 Desde 2004, quando ocorreram os últimos toques de recolher organizados pelo PCC (Primeiro Comando da Capital), o bairro tornou-se alvo de preocupação pública e hoje, seus viadutos e calçadas passam por reformas urbanísticas, bem como algumas de suas edificações mais antigas. Desde a posse da nova gestão municipal, muitos depósitos de materiais recicláveis, localizados no bairro, foram fechados, deixando muitos catadores avulsos sem postos para venda dos materiais recolhidos e, portanto, sem possibilidades de renda. Em decorrência do aumento do efetivo policial na região, tem havido constantes reclamações por parte dos habitantes do bairro, sobre o papel da polícia e seu constante uso da força física. Recentemente tem se desenvolvido uma forte tensão entre a guarda civil metropolitana e os catadores que vivem e trabalham na região. Também o primeiro escritório do projeto "Nós do Centro" - um novo projeto de "inclusão social urbana" no centro da cidade, resultado de um programa bilateral que participa tanto a Prefeitura Municipal de São Paulo (PMSP) quanto a União Européia
} 
A paisagem da Baixada do Glicério também é intensamente marcada pela presença de pontes, viadutos e elevados. Toda esta trama viária que sobrevoa a baixada faz com que o Glicério seja um lugar de passagem para muitos habitantes da cidade, um lugar de passagem que sequer é percebido. Passa-se de carro sempre por cima ou ao seu lado, por vias expressas que levam à Av. 23 de Maio, à Radial Leste ou a outras vias expressas. Estas vias ligam o Centro, o Sul e o Oeste da cidade ao Leste e ao Norte. Mesmo não sendo notado por muito dos citadinos que apressadamente cruzam "por cima" do Glicério, ele permanece sendo um território de pertencimento para múltiplas relações e interações, trocas e jogos sociais, sociabilidades públicas e de rua. É um lugar repleto de atribuições de sentido e que funciona como espaço de ancoramento e demarcação simbólica para seus habitantes e praticantes. Contudo, é justamente esta intensa vida local, com suas modalidades próprias de ação e regras de conduta, que faz desta região moral um "problema" para as autoridades municipais. Tratase de um território cujo trabalho informal é a grande tônica das atividades geradoras de renda, como a economia do lixo e o comércio de drogas. E é nesta paisagem que se situa o albergue São João.

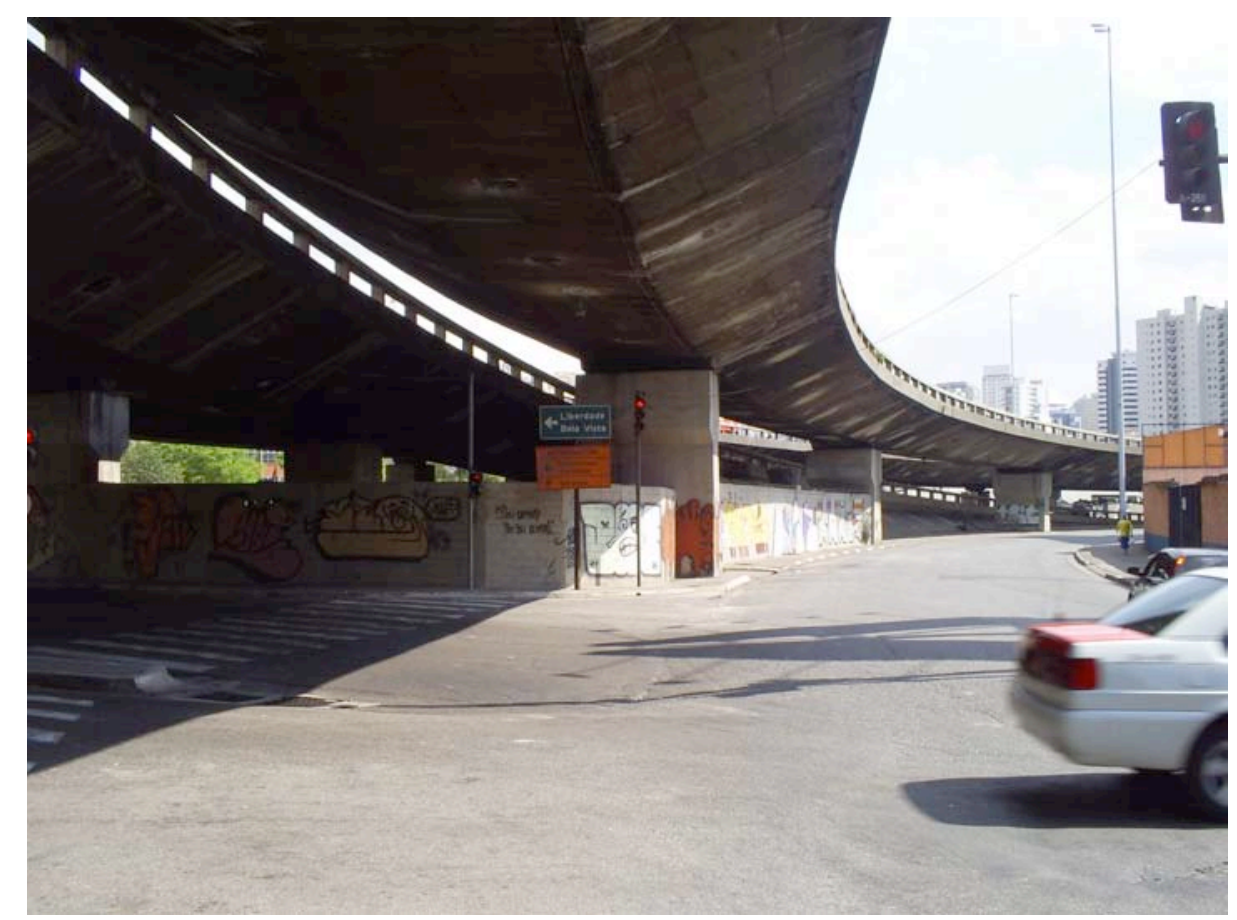

Paisagem do Glicério: território submerso numa trama viária que o sobrevoa

Foto: Daniel De Lucca Reis Costa

(EU) - foi montado justamente no Glicério, por ser visto como uma das áreas mais problemáticas do Centro. Este mesmo projeto demonstrou que no Glicério há pelo menos 17 ONGs que trabalham só na temática de gênero, além de toda uma grande dinâmica de associativismo voltada para outros temas, tais como juventude, droga e alcoolismo, moradores de rua e catadores. Além disso, é na Baixada do Glicério que se localizam as atuais secretarias de articulação dos dois movimentos sociais aqui citados, o MNCR e o MNPR. 
Meu primeiro contato com a instituição foi visual. Ao ir a campo ou então simplesmente ao passar de carro pelo Glicério, via aquela enorme fila de gente se mexendo, conversando e falando. Todos debaixo do viaduto e próximos àquela portinha que dá para dentro da instituição. Indiscutivelmente aquela aglutinação de imagens, corpos, gestos e personagens, mormente maltrapilhos, realmente chama a atenção. Provavelmente aqueles que passam "por baixo" do Glicério e se deparam com aquele fenômeno na entrada do albergue, não entendem muito bem o que significa. A entrada da instituição fica em frente a um semáforo, numa via que vai em direção ao elevado. Quando o sinal fecha se estabelece, ainda que de maneira indesejada, uma interação visual entre aqueles que estão dentro dos veículos com as janelas fechadas, os olhos atentos e as mãos precavidas ao volante - e todas aquelas pessoas marcadas por estigmas sociais ou corporais. Algumas sujas ou com problemas físicos, outras aparentemente perturbadas, alguns carregando consigo objetos dos mais variados ou então seguidos por verdadeiras matilhas de cães, e também aqueles mais cabisbaixos e desanimados, esperando apenas por receber uma comida e a possibilidade de dormir numa cama. Decerto esta relação estabelecida - ainda que provisória, instantânea e óptica incomoda os motoristas e passageiros dos automóveis. Neste momento, como maneira de evitar o contágio, os vidros dos carros são fechados.

Aquela miséria e estranheza urbana exposta, justamente no momento em que o sistema de tráfego coloca os que passam numa situação mais vulnerável, pois os imobiliza, aborrece de tal modo os automotivos, que para evitar o contato com a inoportuna cena (infeliz ou exótica), os carros preferem (por medo ou gosto) parar na faixa extrema do outro lado. Das $17 \mathrm{~h}$ às $19 \mathrm{~h} 30$, horário de grande trânsito e tráfego, quando os veículos buscam ocupar todas as faixas, é possível observar que na parada do sinal, embaixo do viaduto, há um buraco no mar de carros. E este espaço vazio corresponde justamente à porta do albergue, com sua fila de gente que se amontoa justamente neste horário, que é o período de entrada na instituição. Uma instituição onde dormem e comem mais de 450 pessoas por dia.

No começo de 2006, entrei em contato com a coordenação da instituição solicitando autorização para realizar a pesquisa no interior do albergue na condição de usuário. Expus o meu interesse e entreguei um pequeno projeto detalhando a pesquisa, minhas referências pessoais e deixando claro que aquele estudo não era uma avaliação da instituição. Inserida à proposta de estudo estava colocado meu compromisso, já cumprido, de apresentar à instituição o relatório da etnografia ao final da pesquisa. Neste processo foram muitas as minhas idas e voltas até o albergue, de tal maneira que a cada visita ia conhecendo um pouco 
melhor as pessoas, as palavras e as coisas que participam daquele universo. Apesar de a negociação ter-se iniciado no começo do ano, foi só em agosto que consegui encontrar-me com o corpo técnico da instituição e pude, então, começar a freqüentar o espaço.

Ao me apresentar para a equipe de funcionários, foi sugerido que passasse por todos os processos institucionais que o albergado é submetido. Interessante sugestão, que foi prontamente acatada. Deixei claro, também, que não gostaria de ser tratado com diferença, fato que, mesmo com muito esforço, não foi possível devido a inúmeros fatores, entre eles o regime especial de freqüência em que me instalei. Com a intenção de estabelecer um distanciamento reflexivo, pernoitei no albergue duas noites por semana, sendo que no total dormi no albergue São João por sete noites e a pesquisa total teve duração de 2 meses. Primeiro aproximei-me da vida cotidiana do espaço albergal através de uma etnografia interna, e só depois conversei e entrevistei os funcionários. Aos poucos fui decorando o nome de algumas pessoas e conhecendo suas vidas, entendendo o papel de cada personagem em toda aquela trama institucional e compreendendo melhor algumas questões captadas no fluxo do dia-a-dia.

No período em que me encontrei no albergue, interagi constantemente com outros usuários, conversei, dormi, comi, usei o banheiro e assisti televisão junto com estes. Por pelo menos sete dias, tentei vivenciar a instituição como um usuário, apesar de possuir alguns privilégios como o de não precisar dormir lá consecutivamente todas as noites e de toda vez poder trocar a roupa de cama, prática esta semanal no caso dos usuários. Posso afirmar que aprendi muito com esta experiência etnográfica, principalmente no que se refere às maneiras mais adequadas de se relacionar e interagir com pessoas estranhas que nunca se viu na vida e que, no entanto, encontram-se extremamente próximas. No início, percebi o ambiente da instituição como algo extremamente pesado, denso, angustiante. Posteriormente, estas impressões, se não foram embora, pelo menos deram espaços para outras. Obviamente não foram apenas sentimentos negativos que lá vivenciei. As sensações foram múltiplas e extremamente variadas. Lá conheci muitas pessoas e ouvi muitas histórias, identifiquei-me com algumas, me diverti, ri muito, aprendi coisas novas, me espantei, senti dó, nojo, raiva e, também, um pouco de medo.

O estabelecimento de contatos é algo que ocorre com muita facilidade. A todo instante é possível travar intercâmbios, tecer comentários e desenvolver uma certa cumplicidade, embora com o passar dos dias tenha notado que estas cumplicidades são assaz fugazes. Numa noite você pode trocar algumas impressões e saber um pouco da história de uma pessoa e logo no dia seguinte, esta pessoa pode passar na sua frente, no café da manhã, sem sequer olhar em 
seus olhos. Apesar de ter conversado com muitas pessoas, foram pouquíssimas aquelas com as quais consegui estabelecer um vínculo mais estável de modo que, quando voltasse para o albergue, dois dias depois, fosse possível sustentar certa continuidade em nossas relações.

Desde o início do campo preocupei-me muito com a reação que as pessoas teriam comigo no albergue. Minha postura foi basicamente a de me comportar como um usuário sem maiores extravagâncias, discursos educativos ou entrevistas. Nas noites em que permaneci no albergue, me trajei de maneira simples. Nos dias de frio usava uma calça, uma blusa preta e um tênis velho. Nos dias de calor, bermuda, havaianas e uma camiseta, às vezes regata. Para minha surpresa, em todas as interações, conversas e trocas, pouquíssimas vezes fui interrogado sobre minha proveniência. As pessoas com as quais me relacionei pareciam estar muito mais interessadas em narrar suas experiências do que em ouvir ou saber das minhas. Deste modo, nas situações de co-presença vivenciadas na instituição, pareceu-me que fui muito mais um foco receptor de histórias e casos pessoais, do que propriamente uma instância de interrogação. Nas interações em que me envolvi, fui muito mais incitado a escutar e ouvir relatos de outros, do que produzir relatos para outros.

Notadamente, nos raros momentos em que minha posição foi questionada, isto servia apenas como trampolim inicial para entabular conversações. Também no decorrer dos diálogos, dei-me conta de que havia todo um leque de papéis sociais nos quais eu poderia ser encaixado, sem maiores problemas nas interpretações locais, tais como: um "hippie que vende uns 'trampos' na rua", "um músico com uma carreira ruim”, ou simplesmente, um "jovem com problemas com drogas". Durante conversas e diálogos, todas estas classes de interpretação foram lançadas. Vale notar que estas classificações êmicas já apontam para um aspecto assinalável: a gigantesca heterogeneidade social daqueles que se utilizam da rede de atendimento à população de rua.

Particularmente nos dias frios, a atmosfera institucional fica muito mais carregada. As pessoas conversam e interagem menos, ficam menos à vontade. A insegurança e o desconforto são como imperativos que pairam no ar. Parece que as condições de frio e chuva tornam explícita a dependência daquelas 460 vidas para com a instituição. Sem dúvida estes períodos são muito mais tensos. São nestas situações que é possível perceber que o albergue, por mais trágica que seja sua existência, constitui-se enquanto último refúgio, último recinto e sítio de aceitação para todo um contingente populacional que não tem para onde ir. Reúno, aqui, apenas algumas impressões reconhecendo seu aspecto fugidio e singular, mas que de modo algum são negligenciáveis ao conhecimento. 


\subsubsection{A entrada e o trabalho da portaria}

O processo de entrada no albergue é um momento delicado. Envolve regras e certos procedimentos rituais de modo a evitar a eclosão de possíveis conflitos e confrontos. Cada instituição possui horários específicos, mas no caso da entrada, seu horário varia de acordo com a situação do usuário. Existe uma importante diferenciação feita sobre o público que se utiliza deste tipo de equipamento: é o cadastro do "pernoite" e o cadastro do "vaga fixa". Estas são duas categorias de usuários que demandam procedimentos institucionais distintos. Ninguém começa sendo "vaga fixa", pois primeiro a pessoa tem de ser candidata ao "pernoite". Se conseguir, adquire um cadastro de "pernoite" no sistema que o reconhece sempre que aparecer no albergue. O "pernoite" cadastrado possui vantagem sobre o "pernoite" sem cadastro, visto que este último não possui nenhum vínculo com a instituição. Para se tornar um "vaga fixa", o "pernoite" deve freqüentar o albergue toda noite durante um certo período de tempo. Este período varia de albergue para albergue. A situação do "pernoite" é instável. Ele precisa pernoitar no albergue todos os dias, evitando possíveis ocorrências na instituição e, de um modo ou outro, tende a estabelecer um bom relacionamento com os funcionários. Não por acaso os "pernoites" são reconhecidos pelos educadores e assistentes sociais como mais comportados que os "vaga fixa", que já estão mais assegurados.

Contudo, mesmo para ser "pernoite", é necessário cadastrar-se no sistema. Aqueles que são cadastrados na instituição (o "pernoite" e o "vaga fixa") e que, portanto, possuem garantia, entram no albergue no período das $17 \mathrm{~h}$ às $19 \mathrm{~h} 30$. Já o horário daqueles sem cadastro e que vão concorrer ao pernoite, varia de albergue para albergue. Assim, para se tentar uma vaga de pernoite, deve-se, antes de qualquer coisa, saber o horário em que tal vaga poderá ser cadastrada e disputada.

No albergue São João o cadastro era às $13 \mathrm{~h}$. No meu primeiro dia de campo (dia do meu cadastramento), cheguei lá antes deste horário e já havia uma grande fila que se estendia pela estreita calçada e onde todos que passavam de carro observavam. No decorrer do dia a temperatura havia baixado repentinamente e eu não tinha levado nenhuma blusa. Depois me dei conta de que este frio que sentia não era nada. Muitos dos que estavam ali se encontravam em situação bem pior do que a minha, sem agasalhos, alguns doentes e também crianças e bebês de colo. A porta do albergue foi aberta pontualmente às 13h. Vagarosamente a fila começou a andar e o educador foi olhando de perto, pedindo documento, um por um, até todos terem-na atravessado. 
Lá dentro ficamos sentados numa área semi-aberta, esperando o necessário atendimento individual para o cadastramento. Só com este é que poderíamos adentrar e “desfrutar" do espaço institucional. Assim, não estávamos nem dentro, nem fora do albergue, mas num espaço liminar, onde deveríamos esperar o chamado do educador para o registro computadorizado. Enquanto isso, um forte vento começou a acompanhar o frio que já nos cercava, e logo depois veio a garoa fina. O tempo passava, a expectativa crescia e aos poucos aqueles aspirantes a albergados começaram a se movimentar, falar e reclamar. Todo mundo queria entrar logo no albergue. A temperatura tinha baixado mais e algumas pessoas já começavam a chorar.

Durante esta espera os educadores pediram o documento de identidade de todos. Só tinha levado o xérox e a educadora (que coincidentemente não sabia de minha situação como pesquisador) reclamou da cópia do RG, mas depois disse que poderia usá-lo. Já outra pessoa que também estava na espera, não teve a mesma sorte. $O$ rapaz foi barrado. $O$ educador gentilmente explicou que como o candidato possuía um cadastro em outro equipamento e já tinha "um código no SISRUA", ele não poderia ser cadastrado e entrar. Em outras palavras, quem possui registro em outro albergue e não pede desligamento, fica "pendurado", não pode se cadastrar em outro equipamento até desvincular-se do antigo. O rapaz que foi barrado não se conformava e disse que aquilo era impossível, pois tinha dormido ali na noite anterior e não houvera nenhum problema. Depois de muita conversa e paciência, o rapaz resolveu ir embora e desistir de sua vaga de pernoite. "Não é culpa nem má vontade dos funcionários", como o educador bem tentou explicar para nós após a saída do rapaz, "na verdade é culpa do sistema, ele é que não deixa cadastrar".

Fiquei toda a tarde esperando para ser cadastrado no albergue. Eu e todo mundo que estava lá. Enquanto isso, conversei com várias pessoas e ouvi muitas histórias. Conheci gente que vive em albergues há anos. Inclusive um senhor contou-me de suas experiências no antigo CETREN. Lá tinha que usar uniforme, mas só se conseguia cadastrar no oitavo dia, "quando eles conseguiam levantar toda sua ficha na polícia”. Como na época não havia sistemas de informação avançados, demorava mais para eles pesquisarem seus antecedentes, mas se você tinha alguma passagem ou devia alguma coisa para a justiça, "depois do oitavo dia parava um móvel tático lá. Era um daqueles opalões da polícia, que chegava para te levar”. Este senhor, que no decorrer da conversa descobri não ser tão senhor assim, também contou sobre o distinto sistema de cadastro no Arsenal. Este albergue, por ser conveniado com o governo do estado de São Paulo e não com a prefeitura, possui um sistema de informações diferenciado e conectado ao da polícia militar: "Lá no Arsenal, se você tem alguma coisa com a justiça, eles 
não te delatam, mas também não deixam você entrar." Por enquanto, o sistema de informações da rede de atendimento à população de rua (SISRUA) não possui acesso aos arquivos da justiça, mas estas experiências comentadas, ao menos acenam para a possibilidade de em algum momento se estreitarem as relações entre os sistemas da vigilância informatizada que atuam sobre a população assistencializada e aquele que atua sobre os contraventores da justiça.

Entretanto permanecia a espera no frio, que durou quase seis horas. Só depois das $18 \mathrm{~h} 30$ é que o cadastramento começou, e bem lentamente. Durante todo este tempo fiquei conversando com os candidatos à vaga e fui notando que grande parte da ansiedade para o cadastramento era devido ao fato de que, como não sabiam se seriam aceitos ou não, pairava no ar a insegurança quanto à possibilidade de conseguirem outro lugar para pernoite na cidade. Assim, a tensão colocada logo na entrada da instituição era decorrente do risco de se encontrarem expostos e vulneráveis numa noite que não se mostrava em nada acolhedora.

Aquela demora, como fiquei sabendo posteriormente através de alguns funcionários, não era algo normal e foi decorrente de um grave problema interno da instituição. O problema maior é que pequena parte dos candidatos a vagas, mesmo depois de esperar por um longo tempo, não foi aceita e teve que buscar outro lugar para pernoite. Alguns não tinham documento, outros estavam alcoolizados e foram barrados. Também apareceu uma família extensa - pai, mãe, tio e seis crianças, sendo duas de colo - e a assistente social explicou que ali não poderiam ficar, mandando-os, através da CAPE, para um outro lugar em que se aceitam famílias.

Ao que parece, portaria do albergue é de maneira geral um ponto nevrálgico na dinâmica da instituição. E isto, não só quando os candidatos vão se cadastrar, mas em todo o movimento do dia-a-dia. Como me narrou uma educadora de um outro albergue:

O portão é uma bomba. Você nunca sabe o que vai acontecer. Você não sabe quem está entrando. Quando o cara está 'noiado' ele fica te xingando, ameaçando e batendo. Aí não deixa ninguém ficar perto da porta. O mais difícil é a gente saber quem pôr e quem não pôr aqui dentro. Só que nem sempre dá para escolher, é muita gente. É muito estressante. Eu mesma, que sou mulher, já quase apanhei no portão várias vezes. Agora a gente (corpo de funcionários) decidiu que mulher não fica no portão. Lá não dá, é muito pesado. Às vezes o cara vem alcoolizado e drogado. Mas ele pode até vir armado, não dá para saber. 
A porta é a membrana que vai tentar filtrar a passagem do ininterrupto fluxo de pessoas e coisas que entram e saem da instituição diariamente. Certas pessoas e coisas não podem passar, ou então, só o podem mediante certas condições e horários. Assim, o funcionário que assume a portaria tem de tomar cuidado para não deixar ninguém entrar fora do horário estipulado. Tem de se precaver com os comentados "noinhas", que podem querer entrar ou levar drogas para dentro do albergue. Deve barrar, também, aquele que se encontra muito alcoolizado e quer entrar na instituição. Todos cadastrados recebem uma pequena ficha que informa sua situação na instituição. Sem mostrar esta ficha para o funcionário da portaria, é impossível entrar no albergue. Contudo, estes princípios são altamente flexíveis, dependem da orientação geral da organização que coordena o albergue, da característica mais geral do público que atende, mas dependem - mais que tudo - da sensibilidade do funcionário que, a todo instante, deve avaliar a situação de maneira a tomar uma atitude mais adequada à especificidade do caso.

Um outro dia, ao tocar a campainha do portão (que no caso do albergue São João, é apenas uma pequena e resistente porta de metal), fiquei esperando o funcionário vir atender, e nesta espera, foram chegando outras pessoas. Era o período de entrada e todos que já estavam cadastrados queriam entrar. Havia um senhor um tanto alcoolizado que durante esta curta espera já começava a esmurrar a porta com fortes batidas. Logo que o funcionário abriu o portão, este senhor quis passar. O funcionário gentilmente pediu a ficha de identificação, ele disse que tinha esquecido lá dentro e mais uma vez tentou passar com força. Foi barrado pelo funcionário. Nisso o senhor já começou a gritar, falando que aquilo era um crime e que tinha o "direito social de entrar no albergue". Enquanto isso, todos os que também queriam entrar, esperavam o encerramento da peleja, já que o senhor havia tomado a frente da porta e monopolizado o funcionário. Este último, no início foi delicado, mas quando começou a ser ofendido verbalmente, perdeu o controle de tal modo que fechou o portão sem ninguém entrar. Logo apareceu outro educador na porta (já que o anterior perdeu a calma e passou o caso), explicando ao senhor que ele não deveria ofender as pessoas e que se ele tivesse paciência, seria feita uma outra ficha de identificação. Só aí que o senhor e todos que estávamos na fila, começamos vagarosamente a entrar.

Esta historieta apenas evoca um evento institucional corriqueiro e que ocorre todos os dias, durante todo o dia. Mesmo não sendo o horário de entrada, sempre aparece alguém pedindo encaminhamento, querendo entrar, usar o banheiro, pedindo para falar com a assistente, desejando pegar o documento que deixou com o educador, querendo encontrar alguém que está dentro da instituição: "Toda hora tem gente querendo entrar no albergue e 
fazendo confusão. Não dá para descuidar”, desabafa comigo o porteiro de outra instituição. Apesar de haver regras explícitas sobre quem pode entrar, quando pode e como pode, cada caso sempre é um caso. E cada singularidade demanda a devida atenção do funcionário.

Entretanto, muitos contatos estabelecidos na porta do albergue eclodem realmente em confrontos físicos, quando funcionários são ameaçados ou agredidos, ou então, quando usuários discutem e brigam na fila de entrada. Nestes casos apela-se para a polícia que, ao chegar, nem sempre demonstra a mesma compreensão e paciência que os funcionários no tratamento com este público mais desfavorecido. Por isso, a portaria é uma atividade que demanda uma série de procedimentos estandardizados, padronizados, ritos de instituição. Contudo, nem sempre estes atos rituais solucionam a discórdia e o disparate. Quanto mais o risco aumenta, mais os responsáveis por sua manipulação têm de recorrer a outras fontes de poder, como a polícia.

Assim, assumir a portaria do albergue significa assumir a responsabilidade sobre aquilo que entra e aquilo que sai da instituição. É neste lugar de passagem e contato entre o "dentro" e o "fora", que há um intenso e ininterrupto trabalho de identificação, seleção e triagem de sujeitos e objetos. Neste ritual de passagem face a face, se estabelecem formas de interação diversas, que em geral envolvem condições de coerção, conflitos renitentes e o intercâmbio de pressões e influências desiguais. A portaria do albergue é o ponto onde dois mundos - e muitos outros - se tangenciam, se cruzam, mas também se afrontam. Justamente pelo fato do albergue ser uma instituição que demanda o fluxo perpétuo de entrada e saída, é que as linhas que desenham o limite dos mundos sociais precisam ser permanentemente repostas pelo trabalho de interface da portaria. Um trabalho potencialmente infinito visto que busca delimitar, codificar e desencorajar a transgressão de um movimento de pessoas e coisas que sempre estão mais ou menos misturadas e embaralhadas entre si.

Esta talvez seja a principal diferença entre o albergue e as instituições chamadas por Erving Goffman de totais. No albergue, as relações intra-muros e extra-muros são muito mais permeáveis e porosas. Ele permite uma abertura para fora, na verdade insiste nesta abertura. Esta instituição estimula a todo tempo a conexão de seus usuários com algumas relações "externas": com o trabalho, com a família, mas também com a saúde. Até porque uma das condições para a aquisição da comentada autonomia é justamente que seus usuários não dependam mais do albergue, mas que constituam relações fora do albergue. Como bem me explicou uma assistente social: "Para ter reinserção social, o indivíduo tem de participar da sociedade e para entrar na sociedade, ele tem de sair do albergue". Contudo, ela mesma sabe que as coisas não são tão fáceis assim: “Às vezes o indivíduo não tem nem capacidade física 
para procurar trabalho. Eles não têm qualificação para disputar emprego. Também, a família não quer receber a pessoa. Ou eles nem têm família”.

Apesar de haver muitas semelhanças assinaláveis, o albergue demarca uma importante diferença com as instituições fechadas, precisamente devido ao tipo de abertura que suscita. Uma abertura constante, mas que não é livre, e sim foco de intensa preocupação, administração e controle. O mais notável de tudo isto é que este controle da passagem é muito mais voltado para os fluxos que entram do que propriamente para aqueles que saem. Apesar do trabalho de superfície-limite, desenvolvido na portaria, voltar-se também para a possível saída de objetos furtados no interior da instituição, a maior preocupação é gerir a correnteza diária que insistentemente busca entrar. A demanda por vagas é sempre superior à oferta. Assim, a maior luta dos usuários é para adentrar na instituição, ancorar seus corpos e subjetividades, conseguir um lugar para dormir, comer e descansar. Como a pressão do fluxo dos usuários é majoritariamente de fora para dentro, a preocupação do albergue é justamente adotar mecanismos institucionais capazes de reverter tal fluxo, mandando-os de novo para fora e, assim, "reinserí-los socialmente".

\subsubsection{As regras, o espaço albergal e o achatamento das diferenças}

Após ser cadastrado, o usuário participa de uma rápida "aula" sobre o funcionamento da instituição e das regras que a regem. Em meu primeiro dia como usuário, participei de uma exposição destas. Um educador nos levou para uma sala, apresentou-se e disse qual a função da instituição: "dar forças para vocês se reerguerem socialmente e se reintegrarem efetivamente à sociedade". Explicou que a coordenação do albergue é de responsabilidade de uma ONG ligada às obras da Ordem religiosa. Esclareceu também que a prefeitura contribuía apenas com $70 \%$ dos gastos e a Ordem completava o resto. Desde 2002, a ONG coordenava o albergue que antes era coordenado por outra instituição. Naqueles dias o albergue São João contava com 460 usuários, sendo 44 idosos e 70 mulheres. Também, no período diurno, aquele espaço funcionava como núcleo de serviços, com capacidade de atendimento para 200 pessoas.

Quanto às regras, elas eram bem claras. Lá dentro não se pode beber, usar drogas, nem fazer carícias nas mulheres. Também é proibido arranjar confusão e briga com outros, tampouco com os funcionários. Qualquer uma destas ações resultaria na expulsão imediata dos participantes. No caso de uma briga, os usuários seriam expulsos, "independentemente de quem bate ou de quem apanha". A entrada do albergue era entre 17h e 19h30, "nenhum 
minuto a mais, nenhum minuto a menos". A janta era servida entre $18 \mathrm{~h}$ e $20 \mathrm{~h}$. O horário em que se deveria sair do albergue era entre $5 \mathrm{~h}$ e $7 \mathrm{~h}$ e o café da manhã também era servido neste mesmo horário. Os usuários do albergue não têm direito a ficar lá durante o dia, tampouco almoçar ali. Cada um tem sua cama numerada. Este número é o mesmo do maleiro e também o mesmo número da ficha individual que o usuário deve sempre carregar consigo. Igualmente é proibido andar pelo interior do albergue com as respectivas bagagens. Estas devem ficar sempre no maleiro. Pode-se pegar os utensílios do maleiro e levar para o interior da instituição, mas não a bolsa toda. Do mesmo modo é proibido fumar nas dependências internas do albergue, somente nas áreas externas é permitido.

No final da apresentação, o monitor responsável pediu desculpas antecipadas pela possível falta que algum educador "possa vir a ter": "Como são muitas pessoas aqui dentro, é possível que em algum momento vocês sejam tratados não da maneira que vocês desejam, então já peço desculpas antecipadas, em nome de todos educadores que possam porventura ofender vocês". Após ter falado isto, todos aplaudiram e elogiaram aquele educador que aparentemente seria o único "funcionário a reconhecer os maus tratos vividos no albergue", como empolgadamente falou um senhor. Após o rápido evento pedagógico, o espaço da instituição foi apresentado.

O albergue São João é bem mais amplo do que aparenta visto de fora. Ao se passar pela porta de entrada, cruza-se uma área semi-aberta onde se espera pelo registro no SISRUA. À frente encontra-se a recepção, uma ante-sala com mesas e computadores utilizados para o cadastramento e onde sempre há algum educador. Só depois que se atravessa a recepção é que o espaço interno começa a se abrir para outros cômodos, e se pode perceber como realmente é grande lá dentro. Como o albergue localiza-se embaixo de um viaduto, sua forma acompanha parcialmente o contorno do elevado. Sua silhueta é comprida. Na entrada começa reduzido e mais estreito, mais à frente vai se alargando e se abrindo nas laterais, e no final, seguindo um corredor, volta a se estreitar. Neste corredor é possível ler uma grande placa indicando que é proibido aos homens prosseguir. É justamente neste final que se situa a ala das mulheres. Mas retornemos à entrada.

Após passar pela recepção, chega-se ao bagageiro. Parada obrigatória e onde se tem de deixar os objetos pessoais. O horário de seu funcionamento também é rígido, abre às $17 \mathrm{~h} 30 \mathrm{e}$ fecha às $20 \mathrm{~h}$. Depois deste período não se pode mais ter acesso aos objetos privados. Em verdade o bagageiro é um ponto de controvérsia generalizada em quase todo sistema albergal. Opera como um mecanismo que evita possíveis roubos da instituição, já que impede a circulação de bolsas e sacolas em seu interior, e funciona também de maneira a evitar a 
entrada de objetos tidos como ilícitos: armas, bebidas ou drogas. Contudo, em alguns albergues os bagageiros não possuem tranca, de maneira que os furtos entre os usuários são constantes e as reclamações decorrentes também. Além disso, os espaços para guardar os pertences são muito pequenos, o que causa grande reclamação devido à impossibilidade de se guardar todos os objetos pessoais. Presenciei várias discussões em torno do uso do bagageiro. Conto aqui um pequeno caso que observei em outra instituição.

Jefferson, que trabalha no ramo da construção civil e mora no albergue, chegou bravo na coordenação alegando que sua bota fora "roubada" pelos funcionários. Era uma bota “daquelas com bico de ferro e que duram a vida toda". Para piorar, a bota não era dele, era da empresa que trabalhava. Por isso cobrava da coordenadora $\mathrm{R} \$ 30$, para comprar uma bota nova. A coordenadora daquele albergue - que alguns usuários familiarmente chamavam pelo nome de "mãe Shirley" - explicou para Jefferson que ele sabia que não podia deixar a bota no dormitório e já tinha sido avisado várias vezes para retirá-la de lá, mas não o fez. "Acho que alguém enfim tomou alguma atitude", disse a coordenadora. Jefferson não gostou da resposta e fez uma cara feia. "Por que você não guardou a bota no armário, se você sabia que ela iria ser retirada um dia ou outro?", disse a coordenadora. A resposta foi explosiva: "porque não tem mais espaço no meu armário. Lá eu já guardo as minhas coisas, minha roupa, está cheio de coisa lá, não dá para guardar mais uma bota!.” Pelo menos naquele momento, a questão não se resolveu. Jefferson saiu de cara fechada e sem seu dinheiro.

Além do problema da falta de espaço, tem a questão da falta de horário, já que seu uso é restrito a determinados períodos, com o intuito de diminuir os roubos. A todo o momento as pessoas acessam o maleiro para pegar uma roupa, uma escova de dente, um pente, um livro ou um documento. Se o objeto possui um certo valor - como um rádio, uma gaita ou até mesmo uma bola -, o usuário tem de saber calcular o tempo de uso do objeto para guardá-lo antes que o bagageiro feche. $\mathrm{O}$ manuseio destes acessórios se faz importante, muito mais no interior de uma instituição como o albergue, já que possibilita marcar uma singularidade frente à multidão de pessoas que coabitam um mesmo espaço. Erving Goffman (1974) chama de estojo de identidade todos aqueles artefatos, acessórios e a "parafernália" que ajuda na produção de distinção entre pessoas e grupos, indicando quem são. No espaço albergal, o acesso a estes utensílios de identidade é extremamente dificultado, pois depende do acesso ao bagageiro e, portanto, de seu horário de funcionamento. Assim, o bagageiro explicita uma grande dificuldade para aqueles que vivem no albergue: a dificuldade em manter uma individualidade num espaço que é maciçamente coletivo e que o porte de objetos demarcadores de distinção é dificultado. 
Mais à frente, no interior do albergue São João, vemos a sala da televisão, que é um importante recinto na instituição. Além de permitir articular a passagem para os outros cômodos, é ali que as informações coletivas são passadas pelos funcionários aos usuários. Também é lá que, depois do jantar, as pessoas se encontram para conversar e desenvolver alguma forma de sociabilidade. Esta sala situa-se na parte mais larga do equipamento com vários bancos de madeira arrumados em colunas e voltados para o aparelho de televisão. $\mathrm{O}$ voluntariado é algo relativamente comum na rede de atendimento à população de rua na cidade de São Paulo. Uma vez por semana, o albergue São João recebe dois voluntários que desenvolvem uma atividade com os usuários naquela sala. Eles apresentam uma lição bíblica e fazem uma discussão, normalmente tentando estabelecer conexões entre o trecho discutido e a vida do "morador de rua". Assim, são debatidos temas como bebida, auto-estima, saúde, trabalho e família. No caso da lição bíblica acima comentada, ela nem sempre é bem recebida por todos, enquanto outros já se envolvem ativamente. A única reclamação forte que se faz em relação a estas pequenas "pregações" é que como elas são feitas na sala de televisão e no período logo após o jantar, normalmente ocupam um tempo que poderia der usado para se ver TV. Jornal Nacional e jogo de futebol são, ao que parecem, os programas televisivos preferidos no albergue.

Olhando para frente da televisão, ao lado direito da sala, existe uma porta que dá para uma ampla área aberta. Lá é o espaço propício para a troca, para a conversa fiada, para o encontro em grupo. Lá se fuma cigarro, se joga xadrez e, algumas vezes, se joga bola. O fundo desta área aberta dá para um elevado e, atrás deste, há uma gigantesca igreja neopentecostal, Deus é Amor, onde se pode ler: "O maior templo do Brasil". Como o fundo desta área é parcialmente coberto pelo elevado, este pedaço é sempre muito escuro à noite, fazendo com que os monitores a toda hora passem por ali, "para ver se ninguém faz o que não deve", como me explicou uma educadora.

Logo na frente da sala é possível ver a cozinha em funcionamento. É uma cozinha industrial, com panelas grandes e uma nutricionista responsável pelo planejamento alimentar de 460 bocas. Posso dizer que a comida não me agradou muito. O jantar é normalmente composto por suco, arroz, feijão, algum tipo de mistura e salada. Para se comer, deve-se pegar uma fila. Quando chega a vez, entrega-se a ficha individual, onde será marcado que a pessoa já se alimentou. Isso é feito, pois, segundo me informaram, "alguns espertinhos sempre querem repetir". A pessoa é servida num balcão, que separa aqueles que comem daqueles que fazem a comida. Normalmente a quantidade de comida servida em cada prato é grande. Os pratos são todos de metal e fundos. Como o jantar é servido na hora do rush, enquanto se 
come é possível ouvir por cima do teto, no elevado, os sons estridentes dos automóveis, seus motores e suas buzinas de impaciência no trânsito.

Na parte de trás da sala de televisão fica o banheiro. As privadas possuem portas sem tranca. A pia é uma bancada única de alumínio onde se pode lavar as mãos e o rosto. E o chuveiro é aberto, tornando visíveis os corpos em limpeza. Em alguns albergues o banho é obrigatório, sendo que o usuário não pode entrar no dormitório sem antes se banhar. Em outros albergues não se pode tomar banho de manhã, somente à noite. No albergue São João o banho não é obrigatório, mas "incentivado". Este incentivo pode vir tanto do corpo dos funcionários, quanto dos usuários. Ouvi casos que relatam situações em que determinado companheiro de quarto encontrava-se em tal estado de "odor", que aqueles que dormiam próximo lhe deram uma surra e o expulsaram do dormitório. O banheiro é um lugar privilegiado para se fazer "coisas erradas" na instituição, como fumar, brigar e fazer sexo, por isso é foco de constante vigilância pelos monitores.

À esquerda da sala ficam os dormitórios. Cada quarto possui vários leitos, todos numerados. No albergue São João eram cerca de cinqüenta leitos por dormitório. Os beliches são dispostos um do lado do outro, nos dois lados do dormitório, formando uma espécie de corredor no meio. A distância entre um beliche e outro é mínima, fazendo com que, à noite, os corpos fiquem extremamente próximos. Em alguns quartos, quase não há circulação de ar e à noite a atmosfera noturna é muito quente e abafada, contudo, a sonoridade é explosiva. Toda uma polifonia invade o quarto: roncos e mais roncos, tosses e mais tosses, cuspes, catarros, conversas, bebidas, discussões, brigas e sexo. Sem falar no barulho da rua, que a todo o momento invade a instituição. Como o albergue São João encontra-se cercado por vias expressas, entre ruas movimentadas e debaixo de um viaduto que funciona 24 horas, durante a noite, deitado na cama, é possível ouvir os automóveis que não param de passar, buzinar, frear e derrapar. Com um pouco mais de atenção é até possível distinguir, só pelo tremor e pelo som que prolifera na instituição, se o veículo que passa próximo é um caminhão, um ônibus, um carro ou uma moto ${ }^{80}$.

Nos dormitórios os mais doentes ficam próximos à porta, área mais ventilada no quarto, para facilitar o acesso ao banheiro como também para diminuir a possibilidade de

\footnotetext{
${ }^{80}$ Além disso, durante toda a pesquisa de campo, o viaduto do albergue esteve em obra. Esta reforma obviamente produzia um enorme impacto na vida cotidiana da instituição. Como a obra mexia com a estrutura física do próprio equipamento, os trabalhadores da reforma a todo tempo tinham de entrar e sair da instituição, levando escadas, máquinas e outros artefatos. Esta atividade, além de demandar uma maior atenção para o responsável da portaria (já que nestas passagens, outras pessoas também queriam entrar ou sair), incomodava a todos, pois produzia um barulho ensurdecedor. Marteladas, furadeiras, lixas e britadeiras criavam ondas acústicas que invadiam e desenhavam a paisagem sonora que dominava o espaço albergal.
} 
contágio de doenças respiratórias, como tuberculose e pneumonia. Esta proximidade com os mais doentes é alvo de constante reclamação e pode causar violentas brigas. O número do leito corresponde à já comentada ficha individual. Todas as atividades do interno na instituição são registradas nesta fichinha: a alimentação, o banho e a passagem pelo atendimento com a assistente social. Apesar de no albergue São João não ter sido freqüente, presenciei em outras instituições, mais de uma vez, funcionários conversando entre si e referindo-se aos usuários através dos números dos leitos: "sabe o 159?", ou então, "você viu o que o 37 aprontou?".

Às $21 \mathrm{~h}$ as luzes são apagadas e fecha-se o acesso à área aberta. Alguns vão para suas camas, ficam vendo televisão, ou então, permanecem vagando pelos espaços. As luzes do dormitório se acendem às $5 \mathrm{~h}$ da manhã. Levanta-se para tomar um copo plástico de café com um pão sem manteiga, e para isso se pega mais uma fila. Pode-se ficar no albergue até às $7 \mathrm{~h}$, quando todos têm de ir embora, mesmo que seja para voltar logo depois, às 10h, como usuários do núcleo de serviços.

Próxima à recepção, localiza-se a sala de atendimento dos assistentes sociais, em cuja ante-sala sempre há pessoas aguardando. É neste espaço que um importante ritual institucional se realiza e traça significativas conexões entre discurso, poder, vida e verdade. Desde sua entrada no albergue, pelo menos uma vez por mês o usuário deve passar pelo atendimento com algum assistente, e em cada vez recebe uma marca em seu cartão individual, comprovando sua passagem. No primeiro atendimento, a assistente pergunta a causa de ele estar em "situação de rua". Lá, a pessoa deve detalhar sua situação, explicar porque veio parar no albergue, colocar sua vida em discurso. É através daquele exame que o usuário elabora um discurso sobre si, sobre a verdade de sua existência e as ínfimas tragédias pelas quais passou. De modo a provocar a confissão das pequenas faltas e fraquezas, freqüentemente pergunta-se sobre sua relação com o álcool, com o corpo, com sua família, com sua casa e seus trabalhos anteriores. São nestas relações que são investidos os discursos, tanto daquele que interroga, quanto daquele que confessa. Assim, o fino fio da linguagem vai passando e costurando os pontos do acolchoado autobiográfico, vai ligando os pequenos retalhos da vida, tecendo um discurso sobre as minúsculas incapacidades e as turbulências do dia-a-dia. Irregularidades mínimas que se fossem manifestas em outras condições e por outras pessoas seriam tidas como sem importância. O desabafo de um usuário explicita isto: "Todo mundo deste planeta bebe, fica na rua, falta algum dia no trabalho e briga com os filhos. Mas a gente não pode e se eu fizer qualquer coisa dessas, o assistente vai e briga comigo. E por que isso? Porque acham que todo mundo aqui é mendigo!”. Mas é todo este conjunto de desordens pequenas e 
ordinárias que o discurso do atendimento assistencial tem o poder de fazer aparecer e que aos poucos vai transformando-se numa poderosa verdade, transforma-se enfim na "causa para a situação de rua".

Este momento ritual é importante, pois é ali que a ficha social é feita, registrada, acumulada e arquivada no SISRUA. Neste momento o insignificante destes homens infames pois até então ínfimos e sem fama, como diria Foucault (2006c) - cessa de pertencer ao silêncio, surge como discurso, aparece na tela de um computador e passa a circular no interior de um grande dispositivo sócio-técnico. Neste momento, é feito um perfil da pessoa, que também permite identificar e encontrar potenciais comportamentos tidos como de risco. Este perfil é construído, justamente, a partir e pela acumulação de todos estes erros e tropeços. As tipologias são tão variadas e heterogêneas quanto o seu critério de apreciação. Algumas destas tipologias me foram listadas por duas assistentes sociais, e a seguir relato algumas que me pareceram mais significativas: "desequilíbrio psicológico", "baixa auto-estima”, "sucessivo desemprego", "imaturidade", "dificuldade na convivência coletiva", "alcoolista", "estado de dependência", "psiquiatrizado", "tuberculoso" e "portador de HIV".

De fato, a população que circula na rede de atendimento é extremamente heterogênea e indiscutivelmente marcada pela precariedade. Apenas aponto para o fato de que, no momento do atendimento, o que se busca colocar em discurso são sempre elementos correlatos a uma falha, são as fraquezas e as incapacidades. Como me explicou muito bem um usuário: "o SISRUA é um sistema que só aponta as coisas ruins das pessoas, todas as coisas boas não estão lá". São estas as desqualificações e distúrbios que se busca colocar em evidência e reforçar. Isto não por acaso, visto que são estas mesmas palavras e noções que delimitam discursivamente um campo de conhecimento que define a população de rua e, ao mesmo tempo, justifica os financiamentos públicos e privados, orientam as ações institucionais, reconduzem os mecanismos corretivos e integrativos, e norteiam as tecnologias de reparação e reinserção aplicadas sobre ela. Assim, o SISRUA, ao implicar diferentes indivíduos num mesmo conjunto de arquivos e fichas sociais digitalizadas - como por uma repetição tautológica de tragédias e rupturas -, tem o poder de inscrevê-los, nomeá-los e classificá-los oficialmente como população em situação de rua.

A partir do momento inaugural do primeiro atendimento, o usuário da instituição passa automaticamente a ser incorporado neste arquivo digital de modo que, quando aparecer em outro equipamento da rede, sua passagem pelos serviços anteriores, sua ficha social e sua caracterização individual estarão sempre presentes no sistema. Desta maneira, o usuário 
possui menos poder de manobra em suas "estripulias e mentiras", como me disse uma assistente social a respeito dos que insistem em driblar os funcionários.

Pelo que pude averiguar, na rede de atendimento à população de rua, ainda existe muita dificuldade no uso do SISRUA. Esta dificuldade diz respeito à falta de uso do sistema pelas assistentes sociais, mas também diz respeito à manutenção da rede de computadores que, em um momento ou outro, sempre "cai". Além disso, muitos assistentes sociais com os quais conversei alegaram que o sistema não "funciona muito bem", pois não há espaço suficiente nos cadastros individuais para detalhar outras possíveis ocorrências efetuadas pelos usuários. Assim, parte das informações sobre contravenções, transgressões, negligências e desobediências manifestas pelo usuário no interior da instituição, por enquanto não participam do SISRUA e permanecem apenas nos arquivos "analógicos" de cada um dos albergues.

Uma grande questão, que perpassa toda experiência albergal, é que este aparato institucional tende a lidar com uma enorme multiplicidade de percursos, corpos e subjetividades de uma mesma maneira, achatando as diferenças e nivelando por baixo todo um conjunto dessemelhante de variações sociais. O conjunto dos procedimentos institucionais estandardizados e suas regras resultam numa forte tendência ao tratamento indiferenciado. $\mathrm{O}$ funcionamento do albergue - com todos seus lugares marcados, fichas, filas, séries, portas, camas numeradas, horários e intervalos temporais sucessivos e calculados - tem o poder de impor uma organização espacial e temporal única, numa multiplicidade de vidas humanas.

Apesar de tudo disso, sabe-se, também, que todas estas rígidas regras institucionais são justamente aquilo que tornam possível a coexistência de uma multidão de pessoas num mesmo espaço e num mesmo tempo. Sobre isso, é interessante o comentário que ouvi de um albergado: "Eu sei que este negócio (o albergue) faz o que quiser com a gente, ele manda na gente. Mas se não tivesse estas regras seria impossível viver aqui”. Num mesmo curto relato é possível compreender a ambivalência do papel das regras: de um lado ela controla a vida na instituição e, de outro, é ela que torna viável seu funcionamento. Em outras conversas ouvi opiniões de que "no albergue não se pode fazer nada, tudo precisa de autorização", ou então, de que "deveria haver mais ordem aqui. Estes caras (os funcionários) são muito moles, se ficassem em cima, aqui seria bem mais limpo e arrumado". Vemos então que mesmo críticos às normas e às práticas codificadas do albergue, os usuários também são capazes de produzir um sentido positivo em relação às regras, pois sem elas "seria impossível viver aqui”.

De qualquer maneira, as regras, normas e codificações institucionais diárias tendem a resultar num nivelamento das diferenças, e esta indiferenciação é objeto de constante reclamação. Além disso, a constante referência às condições unicamente intra-institucionais - 
que "deveria ser melhor", "deveria haver mais albergues", "deveriam selecionar melhor que entra", "a comida deveria ser melhor", "deveria ter uma psicóloga" - parece ter promovido novas formas de problematização de si. Apesar da classificação "população de rua" ter fornecido uma posição (ainda que instável) para um sujeito historicamente liminar, tal categoria tem sido rejeitada por algumas pessoas que circulam e dependem do sistema albergal. Isso devido ao repúdio à classificação população de rua. Muitos usuários fazem questão de marcar uma diferença com aquilo que é chamado por população de rua, pois, estes indivíduos teriam "problemas mentais e de alcoolismo", enquanto os albergados seriam apenas "desempregados sem casa própria". Assim, de modo a não se reconhecerem mais como "em situação de rua", a categoria "albergado" aparece como uma importante fronteira classificatória e de identificação neste circuito. Tendo como ponto de referência primário o albergue, vemos como esta instituição participa ativamente da constituição de novos sujeitos: os "albergados".

\subsubsection{Escalonamento, relações de poder e lógicas da rede}

No espaço albergal há também aquilo que Goffman chamou de escalonamento institucional, uma explícita demonstração de que a equipe dirigente é de qualidade humana extremamente diversa e diferente dos usuários. Os funcionários possuem banheiro próprio, refeitório próprio, bagageiro próprio e entram no equipamento por outra porta. Em alguns albergues os funcionários utilizam avental branco e, em outros, os usuários são obrigados a vestir um pijama. Todas estas diferenças, algumas sentidas pelos usuários como privilégios, operam como demarcações, limites e barreiras simbólicas entre dois atributos de vida que convivem diariamente no interior de um mesmo espaço: os que cuidam e os que são cuidados. $\mathrm{E}$ as formas nas quais as relações sociais internas são reguladas tendem a reforçar continuamente este escalonamento.

Ao entrar no albergue e atravessar os vários procedimentos institucionais de identificação, exame, classificação, registro e numeração, o usuário vai construindo também uma série de disposições internas que passam a ordenar suas relações com aqueles que “cuidam" dele, mas também em relação aos outros com quem convive num mesmo insalubre e limitado espaço. Estas travessias por sucessivos rituais institucionais tendem a reforçar um rebaixamento nas relações com a instituição e com seus dirigentes. Isso eles mesmos falam: "a pessoa tem que não gostar muito de si, para vir parar num albergue". O ambiente vivido na instituição expõe um sentimento generalizado de que o albergue é um espaço de alta 
concentração de "perdedores" e "desfavorecidos". Outras definições locais, como "isso não é lugar para gente", "no albergue você não é ninguém", ou então "isso aqui é um depósito de carne humana", atestam uma significação eminentemente negativa sobre a experiência albergal, que reforça e define a própria condição de seus usuários.

As enormes e freqüentes filas, a convivência forçada com gente "estranha", a permanente exposição corporal, o horário e o ritmo diário imposto pela instituição, o imperativo da carteirinha onde se registra todas as atividades, a necessidade de ter de relatar e justificar certas práticas para os profissionais, e a impressão de todo o tempo ser monitorado e vigiado são experiências diárias que produzem a impressão de incapacidade, infantilidade e imaturidade para gerir sua própria vida. Isso explica um pouco a raiva e evitação que alguns usuários possuem para com a equipe técnica da instituição, um tipo de sentimento pautado pelo medo da cobrança e da repreensão cotidiana.

Um usuário forneceu-me uma explicação para sua evitação com a assistente social: "não falo com a assistente porque ela sempre quer saber se eu estou trabalhando. Quando eu falei para ela que ainda não consegui um emprego, ela disse que eu era relaxado e que logo, logo, ia ter que ir embora do albergue". Também presenciei (não no albergue São João) alguns monitores gritarem com os usuários. Sobre isto, ouvi de um usuário: “eles gritam com a gente e tratam a gente sempre como se estivéssemos errados. Eles acham que têm alguma autoridade. Só acham, porque na verdade não é poder nenhum ficar gritando com gente que não tem onde cair morta".

Além disso, os funcionários são constantemente acusados pelos usuários como responsáveis pelas precárias situações em que se encontram. Há uma espécie de senso comum, reinante nos equipamentos da rede de atendimento, que diz respeito à desconfiança generalizada sobre o uso das verbas públicas que vão para as organizações responsáveis pela coordenação do serviço. A sofisticada elaboração de um usuário explica um pouco melhor este senso comum: "O terceiro setor é um labirinto social. A grana que entra aí, se perde. E quanto menos qualificado o beneficiário, mais dinheiro no caixa da ONG”. Também, volta e meia os funcionários são acusados como se fossem o "pau mandado do Estado". Já outras vezes são vistos como os agentes da "indústria da miséria".

Mesmo muitas vezes sendo culpabilizados pelos usuários, todos estes "trabalhadores sociais" - os assistentes, os educadores, os coordenadores e os psicólogos - também estão atrelados às exigências técnicas e institucionais, bem como têm de desenvolver suas atividades cotidianas no mesmo espaço albergal, um espaço, senão precário e superlotado, pelo menos insalubre e inadequado para o trabalho de "reinserção social". Ao circular pela 
rede de atendimento à população de rua, conheci muitos funcionários que, em momentos passados de suas carreiras, já trabalharam em outras instituições, outros albergues, casas de convivência, núcleos de serviços, moradias provisórias e cooperativas. Assim, se é verdade que os usuários circulam nesta rede, o mesmo se pode falar dos profissionais que aplicam cotidianamente sua força de trabalho neste circuito assistencial e, bem ou mal, o fazem funcionar.

Uma parte significativa destes funcionários possui faculdade, recebe pouco e faz duas jornadas diárias de trabalho social: uma no albergue e outra em outra instituição. Quando o segundo trabalho não é com a população de rua, é com meninos de rua, com idosos, também em presídios, hospitais públicos, com outras populações de risco ou projetos sociais. Aqueles que trabalham nos albergues seguem um horário puxado, de 12 horas por 36, deste modo, devido à constante alternância de horários que vão se acumulando e se revezando no decorrer da semana, o final de semana fixo é uma impossibilidade. Sabe-se também que o treinamento destes profissionais, quando ocorre, é rápido. Mesmo havendo uma alta presença de "idosos", “casos psiquiátricos", “drogados", “deficientes físicos", "tuberculosos”, “epilépticos" e outros, o trabalho no albergue se aprende fazendo, "se aprende na marra", como se diz.

Além disso, é comum ouvir relatos sobre tensões emocionais, crises pessoais e brigas familiares, decorrentes do trabalho exaustivo com este tipo de público. Como uma assistente me disse, "é comum levar o demônio daqui lá para casa. O Exu nos segue daqui até a nossa casa, e aí você já sabe, é problema". Mesmo com um "salário tão baixo com um stress tão grande", como me foi comentado, diariamente estes profissionais têm de lidar com as diferentes categorias que aparecem, quase todas marcadas, também, pela precariedade. Nas conversas com os assistentes sociais, a questão do trabalho com a "diversidade dos casos" surgiu como um importante tema. Como a população usuária é heterogênea e os problemas são variados, os atendimentos também deveriam sê-lo. Ocorre que "o albergue não possui capacidade de fornecer um serviço que acompanhe a diversidade de demanda. As reclamações são muitas e quase nunca há o que ofertar". Apesar de serem encaminhados, sempre quando possível, para serviços especializados, a dificuldade de lidar com a diversidade permanece, até porque estes encaminhamentos muitas vezes são dificultados, desviados ou bloqueados por múltiplas eventualidades. Vemos então como este dispositivo de segurança e gestão da população de rua incorpora também o crescente mercado de "trabalho social".

Mesmo com todas estas dificuldades, estes "trabalhadores sociais" têm de se apresentar publicamente como participantes de organizações racionais, planejadas e eficientes na reforma e reinserção social de seus assistidos. Suas práticas devem aparecer como 
coerentes e eficazes na acolhida, convivência e geração de autonomia da população de rua. Vemos aqui uma dificuldade com a qual tais trabalhadores têm de lidar cotidianamente, o hiato entre aquilo que realmente fazem e aquilo que oficialmente dizem e lhes é cobrado fazer. Assim, tais profissionais são alvos de enormes críticas tanto por parte do poder público, que destina muitas vezes poucas verbas para os processos de manutenção e funcionamento do equipamento, quanto dos próprios usuários, que os acusam de serem controladores e "exploradores da pobreza". De um lado, enfrentam os desafios diários do atendimento, trabalhando em condições inadequadas e precárias, tendo de lidar, sem a qualificação necessária, com casos extremos de fragilidade física e psíquica, ouvindo cotidianamente reclamações e demandas por parte dos usuários. Por outro lado, têm que cumprir com as exigências impostas pelo convênio, que cobra constantes relatórios de atividades, como o número de pessoas atendidas, encaminhamentos, resultados, número de "moradores de rua recuperados" e futuras propostas de melhorias. Como o coordenador do albergue São João revelou-me: "a gente tem de ter sangue de barata para não sermos afetados pelos pisões que levamos e continuarmos a fazer nosso trabalho". Na rede de atendimento voltada à população de rua, os trabalhadores sociais, aqueles que fazem a conexão entre o grupo-alvo e o Estado, são importantes mediadores, e, por isso mesmo, encontram-se numa agitada zona de turbulência e pressão intensa.

Até agora reforcei o escalonamento presente e reiterado pelos próprios mecanismos internos à instituição. Contudo, se é verdade que este escalonamento possui um caráter antagônico, também é verdade que, ao se atentar mais detalhadamente para a vida cotidiana do albergue, poder-se-á apreciar melhor como as estratégias e os jogos de poder nos quais os agentes se engajam são multifacetados e dinâmicos. De tal maneira que as relações de poder existentes no albergue são muito mais dispersas e distribuídas do que o antagonismo de classes, "dirigentes" e "dirigidas", pode remeter.

No espaço albergal opera uma desigualdade, que é resultado de uma série de intermediações não simétricas, defasagens e hierarquias distribuídas. Aquilo que é chamado de população usuária do albergue, ou simplesmente os albergados, é uma realidade cruzada por diferenças e desigualdades. Em sua composição vêem-se itinerários múltiplos, tanto no que se refere às trajetórias profissionais, quanto habitacionais, educacionais e, também, institucionais - visto que certo público mais recente também tem se caracterizado por possuir outras experiências institucionais, tais como orfanatos, penitenciárias, hospitais e asilos 
psiquiátricos. Devido à concentração desta multiplicidade humana, as tensões e alianças são constantes, gerando conflitos, roubos, agressões e até mesmo assassinatos ${ }^{81}$.

Também, dentro daquilo que estou chamando de corpo de funcionários, há toda uma cadeia de posições e desníveis operando. Poderíamos reconhecer na autoridade máxima da instituição seu coordenador. Esta figura, que normalmente também é acompanhada por um vice, é uma espécie de embaixador do mundo exterior, responsável pelas "relações públicas" da instituição. Faz a intermediação com os órgãos públicos, com os funcionários, com a entidade responsável e mantenedora, com outras entidades, com a vizinhança que sempre reclama. No caso do albergue São João, essa mesma vizinhança pode trazer "problemas" para dentro da instituição, como bebidas, drogas e $\operatorname{armas}^{82}$.

Também há os já comentados assistentes sociais que fazem a escuta, acompanham, orientam, encaminham os usuários e os registram no SISRUA. Já os educadores sociais parecem ser aqueles que fazem o trabalho mais difícil do contato cotidiano com os usuários, assumindo a portaria, ajudando os doentes, fazendo o cadastramento de entrada, coordenando grupos interativos, separando brigas, vigiando, procurando e pegando infratores. Também há a equipe da cozinha, responsável pela feitura das refeições em grande escala; equipe da limpeza; além dos usuários que, devido ao "bom comportamento", se tornaram ou estão se tornando funcionários da instituição. Além disso, em alguns albergues há enfermeiras para ajudar os mais doentes e psicólogos para acompanhar e encaminhar casos específicos. É freqüente também a presença de voluntários em trabalhos mais setorizados, como bazares e grupos de discussão.

Por último, é interessante lembrar da presença dos guardas civis metropolitanos (GCM), que se apresentam como responsáveis pela promoção da segurança do local. Contudo, esta segurança não se faz sem controvérsias. Sabe-se de muitos casos em que estes agentes da ordem têm agredido os usuários, tornando-se, deste modo, os próprios agentes da

\footnotetext{
${ }^{81}$ Cheguei a ouvir sobre o caso de um assassinato no interior do albergue São João. Quem me contou foi um exusuário. Episódio um tanto sinistro no qual, às cinco da manhã, ao acender das luzes, ter-se-ia encontrado um usuário em sua cama morto, com uma faca cravada em seu peito. Especulou-se que durante a noite a vítima tenha sido atacada, sem se dar conta, por algum rival ou pessoa com quem estava em profundo atrito. Contudo, é importante ressaltar que tal caso de assassinato não foi confirmado e tampouco negado por aqueles com quem conversei sobre o assunto. Ouvi de usuários que poderia ser muito possível isto ter acontecido, pois tal fato já ocorrera mais de uma vez em outros albergues da cidade. Também ouvi dos usuários que antes aquele albergue era "muito mais barra pesada do que é hoje", "hoje o negócio é muito mais tranqüilo e arrumado do que antes". Além disso, conversando com alguns funcionários mais subordinados na hierarquia interna da instituição, ouvi que este assassinato poderia ter ocorrido lá, pois a atual Província responsável pela coordenação assumiu o albergue apenas em 2002. De qualquer modo, acredito que mais importante do que saber se tal caso ocorreu ou não, é saber de sua presença constante no imaginário e no discurso daqueles que circulam por esta rede.

${ }^{82}$ Numa entrevista com o coordenador do albergue São João, este me relatou que já haviam passado pela difícil situação de terem de lidar com uma "boca de droga" que havia se instalado no interior da instituição. E "foi só com muita tranqüilidade e conversa com os traficantes" que eles conseguiram "botá-los para fora".
} 
insegurança no albergue. Notavelmente, a presença da GCM também responde a outra questão, não mais a da segurança, mas a da alimentação. Muitos guardas comem diariamente nos albergues e outros equipamentos da rede de atendimento à população de rua, contudo se alimentam no refeitório exclusivo dos funcionários. Ouvi várias vezes reclamações, tanto dos funcionários, quanto dos usuários, sobre o fato dos albergues, e outros equipamentos da rede, estarem se tornando "boca de rango de GCM".

Todas estas gradações e diferenças de forças implicam também em formas desiguais de relações de poder com os usuários, que também não devem ser tratados de maneira homogênea. Por exemplo, há usuários que estão há mais tempo na instituição - os mais antigos entre os "vaga fixa" -, são conhecidos pelos funcionários, ajudam na manutenção da ordem e disciplina interna. Estes, ao manterem uma reciprocidade mais intensa e constante com o corpo de funcionários, adquirem certos "privilégios". Observa-se, também, que algumas faxineiras e cozinheiras podem ser "cortejadas" pelos usuários, mas também por policiais, o que é aceitável, ou pelo menos tolerado, na instituição. Já cortejar uma assistente social não é lá muito recomendável, principalmente devido ao poder que estas profissionais possuem sobre aqueles que dependem do albergue e, de maneira mais ampla, da rede de atendimento. Também um usuário pode não se preocupar em entrar alcoolizado no albergue. O problema para ele é quando algum funcionário que acompanha seu caso e tem poder de prejudicá-lo, expulsando-o da instituição, percebe seu estado.

Assim, as relações de poder são estrategicamente distribuídas na compressão espaçotemporal que se vive no interior da instituição. As linhas de força que existem no interior do albergue não decorrem apenas de suas regras ou da autoridade da equipe dirigente. Elas dependem de variações situadas e conexões mais ou menos extensas. Como diz Foucault: “Aquilo com que se tem de lidar, antes de lidar com as instituições, são as relações de força nessas disposições táticas que perpassam as instituições” (Foucault, 2006:20). Assim, o escalonamento da instituição não é binário, é atravessado por multiplicidades, visto que há toda uma dispersão de relações, desequilíbrios de poder, variação de forças e diferenças de potencial. E são estas defasagens que fazem com que o poder se exerça em seu interior, um poder que só pode existir e funcionar porque no interior desta instituição há uma complexa distribuição que encadeia a cronometragem do tempo, a serialização do espaço, a concentração dos corpos, a condução dos gestos e a incitação dos discursos.

Segundo Foucault, é esta cautelosa divisão do tempo e do espaço - uma composição espaço-temporal repleta de filas, colunas, classes, intervalos, números, horários, lugares - que possibilita a ordenação de uma força produtiva cujo efeito é superior à soma desarranjada dos 
componentes e das forças elementares. É esta compartimentação espaço-temporal, que permite, também, que os indivíduos possam ser observados, classificados, avaliados, e suas qualidades medidas no interior da instituição (Foucault, 2001a). No entanto, este espaçotempo analítico e administrativo, que é o albergue, dialoga necessariamente com outras escalas espaço-temporais urbanas. As regras, composições e distribuições que regem a vida albergal se imbricam com seu suposto "exterior", com as relações de vizinhança, com as sociabilidades mais alargadas que a conectam com outros pontos e circuitos da rede de atendimento, mas também com as intrincadas tramas e mediações que as colocam no território paulistano.

Todas as pulsações da cidade e vividas na cidade também transcorrem para dentro dos albergues. Quando a nova gestão (PSDB-PFL) desenvolveu sua campanha "operação limpa" na chamada "cracolândia", recolhendo habitantes das ruas, fechando os hotéis, expulsando as prostitutas e perseguindo os "nóias" ${ }^{\prime 3}$, vários destes personagens liminares, que até então circulavam na região, foram parar nos albergues, em especial aquele do Glicério. Como uma assistente do albergue São João me contou: “quando a operação limpa começou, o número de pessoas procurando vaga aumentou muito. O problema é que nós não podíamos recusar e já estávamos lotados. Uma parte das pessoas a gente tinha que atender, porque chegavam na kombi da CAPE, diretamente da cracolândia e com ordem da prefeitura para recebê-los". Neste caso, a intervenção pública, com o intuito de "civilizar" o espaço da "cracolândia" mais um daqueles "lugares difíceis de descrever e de pensar" -, produziu múltiplas destinações e linhas de fuga que vieram alojar-se e acumular-se no interior do espaço albergal. Deste modo, as ações na chamada "cracolândia" forçaram também a rápida e precária institucionalização de todo um contingente heterogêneo de pessoas.

A CAPE, que faz o transporte de usuários entre os diferentes equipamentos, também é responsável pelo recolhimento dos habitantes das ruas. A kombi - em cuja lataria pode-se ler "Programa São Paulo Protege" - passa nos pontos de maior concentração e os "convida" para serem levados para o albergue. Contudo, tais "convites" são constantemente recusados, pois os albergues seriam "piores que exército", lugares com "muita gente junto", onde "você nunca sabe o que vai esperar". Estas, e muitas outras, são explicações correntes para a recusa à institucionalização.

\footnotetext{
${ }^{83}$ O auge da chamada "operação limpa" se deu em abril de 2005 e foi amplamente noticiada pela grande imprensa. As ações da prefeitura podem ser encontradas com maiores detalhes nos periódicos do O Estado de São Paulo e da Folha de São Paulo referentes ao mesmo período.
} 
O mesmo tipo de dificuldade na institucionalização pode ser encontrado quando sanitaristas públicos vão às ruas, em busca dos doentes tuberculosos. Esta atividade se faz necessária "devido ao alto índice de tuberculosos nas ruas da cidade", como me foi explicado. Assim, a função destes trabalhadores é identificar o bacilo da doença - através de uma delicada coleta de catarros - entre os habitantes das ruas e dos albergues, para posteriormente encaminhá-los para Campos de Jordão, onde há um hospital especializado para tratamento da doença com este segmento. "Os moradores de rua tuberculosos são um problema de saúde pública”, explicou-me uma médica sanitarista em uma visita que fiz a uma UBS (Unidade Básica de Saúde). A principal justificativa para este perigo nosológico que residiria no corpo da população de rua, é que após começar o tratamento, este segmento teria uma tendência a nunca terminá-lo, e tal atitude "aumenta a potência do bacilo da 'tb' devido às gradativas doses de medicamento com as quais o bacilo vai se ajustando". Neste processo, a medicalização deste público necessita de drogas cada vez mais fortes. Assim, há uma preocupação enorme em conseguir institucionalizar estas pessoas para tratamento intensivo, e, deste modo, diminuir o risco de contágio destes "poderosos bacilos". Entretanto, assim como nos albergues, muitos se negam radicalmente a ir para os hospitais ${ }^{84}$.

O dispositivo de proteção social não se restringe à experiência albergal, mas distribuise pelo espaço da rua, intervindo nos locais mais "problemáticos", nos pontos de acúmulo e aglomerado, nos possíveis focos de doença e violência. Toda esta ação é para assegurar os indivíduos dos possíveis riscos existentes na rua, para fornecer proteção e reinserção social, mas também é para civilizar e disciplinar o uso dos espaços públicos. Contudo, este mesmo dispositivo de segurança, que busca dar assistência, integrar e corrigir seres vistos como incorrigíveis, dificilmente gera resignação ou submissão. Pelo contrário, tais sistemas de controle são criativamente burlados, enganados e transgredidos por práticas gazeteadoras extremamente inventivas. Os corpos que, no decorrer das carreiras institucionais, são marcados por poderosas técnicas de inscrição e identificação, não se domesticam facilmente.

\footnotetext{
${ }^{84}$ Em visita à UBS Humaitá, ouvi uma interessante história. Relataram-me o caso de uma pessoa da rua que, depois de muita conversa e insistência, aceitou ser encaminhada para Campos de Jordão por causa da tuberculose. Contudo, alguns dias depois ele reapareceu de novo na UBS, dizendo que tinha dado "alta a si mesmo". A assistente social não tinha entendido e quis saber o que tinha acontecido para ter voltado tão rápido do tratamento. Ligou, então, para o hospital de Campos de Jordão. E aí "me disseram que ele quebrou todo o hospital. Era um negro, grande e forte. Pegou um extintor e quebrou a porta, janela e móveis. Precisou de um monte de gente para segurar ele. Ele não queria ficar lá. Quando ele viu que ia ficar entre um monte de gente doente, estourou". "Depois ficamos sabendo que tinha ido parar no Sirineu (um albergue), arranjou encrenca com uns três caras lá e depois disso sumiu". "Não conseguimos monitorar para onde ele foi e ninguém nunca mais ouviu falar dele".
} 
O usuário do albergue, este consumidor do equipamento também fabrica, produz, inventa e cria novas possibilidades de uso. As operações dos usuários não são entregues à passividade da técnica da disciplina e da normalização, seus corpos de maneira alguma se tornam dóceis. Existe uma miríade de brechas, aberturas e pontos cegos que fazem as relações de poder microbianas, que "curto-circuitam" os equipamentos institucionais, escaparem deste. As práticas dos usuários, suas astúcias e artes de fazer, não se dão contra a rede institucional, se dão, sim, a partir dela. Seus modos de agir não possuem lugar próprio senão os espaços de relações em que estão circunscritos, os subvertendo, os reempregando. Utilizam a rede de atendimento através de combinatórias de práticas e reutilizações destes sistemas, equipamentos e artefatos já produzidos. As astúcias dos usuários, reapropriações culturais dos lugares, materiais e regras tecem redes cujos caminhos são indeterminados, compondo territorialidades marginais (Perlongher, 1989).

Assim, as modalidades práticas desenvolvidas pelos usuários da rede de atendimento são do tipo tático ${ }^{85}$. Todas aquelas regras que são apresentadas aos novatos quando estes entram no albergue são burladas diariamente. Mente-se muito para as assistentes e engana-se os funcionários freqüentemente. Entra-se alcoolizado e bebe-se muito lá dentro. Além disso, fuma-se em praticamente todos os recintos da instituição e usa-se drogas das mais variadas possíveis. Há também muito roubo, briga, namoro e sexo, apesar de haver um forte preconceito com homossexuais. Os pertences pessoais que não se pode levar para dentro do espaço da instituição, os usuários os guardam debaixo das camas. Lá se escondem bolachas, frutas, roupas, comida, toalhas úmidas, giletes de barbear, revistas pornôs, escovas de dente, facas e garrafinhas de pinga. Todos estes objetos são alvos de vigilância constante dos funcionários. Não podem ficar nos dormitórios, "criam bichos", "servem como arma" e "são drogas". E é justamente a não obediência às regras da instituição que a fazem trabalhar, é toda esta transgressão que faz seus mecanismos funcionarem, tapando buracos e falhas, preenchendo desequilíbrios, vigiando comportamentos e gestos, procurando objetos e atentando a lugares.

\footnotetext{
${ }^{85}$ Certeau $(1982,2003)$, ao desenvolver uma teoria e um método próprio para o estudo das práticas cotidianas, estabelece uma interessante diferença entre estratégia e tática. A estratégia postularia um "lugar próprio", susceptível de ser circunscrito e de constituir a base de uma distinção frente a uma exterioridade alvo de cálculo e manipulação. Algo próprio significa uma autonomia ou estabilidade espacial sobre as circunstâncias. É uma capitalização sobre uma base própria que permite resistir mais às metamorfoses do tempo, supõe uma prática óptica de previsão ou de visão do passado. Já a tática é a "arte do fraco", seria a ação calculada ou a manipulação de relações de forças quando não se tem algum próprio e, portanto, quando se está no campo do outro. O princípio tático é locatário, insere-se numa ordem definida por outrem e é em função da ausência desse lugar próprio que calcula a relação de força. A tática é pensada por Michel de Certeau como o princípio fundamental das práticas cotidianas. É deste modo que aqui interpretarei as práticas dos usuários como sendo do tipo tático.
} 
Todas as figuras que circulam neste espaço de relações manipulam taticamente os elementos disponíveis já existentes, operando sobre estes transformações, alterações, desviando-as, deturpando-as, exercendo revisões semânticas. Quando recebem passagens da Prefeitura para voltar para casa, podem visitar sua família e depois regressar. Como me disse um usuário uma vez: "porque é só o morador de rua que não pode fazer turismo, já que todo mundo faz?" Ou então, "bebem" o montante da passagem que ganharam. Alguns pegam a cesta básica da igreja ou do posto de saúde e a vendem, preferindo comer a refeição que as churrascarias dão no final do dia, "muito mais saborosa e sem precisar fazer". Quando estão em algum tratamento médico e ganham passe de ônibus para ir ao hospital, preferem ir a pé, "bebendo" o passe. Pegam camisinhas em postos de saúde ou albergues e vendem para as prostitutas e travestis por $\mathrm{R} \$ 0,15$ a 0,50 cada uma. Pegam as roupas doadas nos bazares de caridade e vendem nos brechós alternativos. Com os recursos disponíveis, os praticantes operam modalidades próprias de uso. Devido à escassez dos objetos, a acessibilidade tem de ser alterada e criada mediante práticas culturais transformadoras e inventivas.

Alguns dos personagens que transitam neste mundo possuem também um enorme conhecimento sobre a rede e o espaço de relações mais amplo que os envolve, pois eles vivem disso, desse fluxo e desse conhecimento. Sabem onde a "boca de rango" é boa e onde não é; quando a instituição é rígida e quando não é; onde há policiais e onde não há; onde se pode entrar alcoolizado e onde não se pode; sabem, também, qual instituição tem acesso à ficha da polícia e qual não tem; sabem quais ruas do Centro em que se distribui comida, lanches e cobertores à noite.

A improvisação da vida cotidiana destes usuários pressupõe um conhecimento extraordinariamente sutil dos códigos, informações e diferenciações operantes num espaço mais amplo de relações. E este saber próprio aos usuários é acessado por sua memória, por conhecer os lugares, por ter ouvido falar deles, ou por tê-los como referência. Como nos diz Bernard Lepetit, “o território é essencialmente uma memória, e seu conteúdo é todo constituído de formas passadas" (Lepetit, 2001:149). Assim, o conhecimento da rede e seus espaços de relações é um saber circulatório, mas que também é uma sabedoria do precário. Os usuários, de uma maneira ou outra, acessam a cidade, mesmo que seja uma cidade de interstícios, avessa e mediada por frágeis institucionalidades. Colocar os usuários no plano de consistência em que vivem e existem implica levar em consideração seus territórios, mobilidades, mediações, conexões, comunicações e toda um sucessão de proximidades e distâncias sociais que os envolvem e que podem se abrir ou se fechar (Joseph, 2005; Agier, 1999). 
$\mathrm{Na}$ rede de atendimento à população de rua vemos como as astúcias e táticas dos usuários são outra face do dispositivo - mais de uma de suas facetas -, que se compõem-se como um circuito itinerante que encontra sua dinâmica intrincada com a malha institucional, ou seja, trata-se de uma relação de divergência e compartilhamento com esta (Frangella, 2004). Deste modo, as maneiras de fazer dos praticantes não representam uma exterioridade ou alteridade radical da aparelhagem institucional, não estão fora dela. Constituem-se, em verdade, a partir deste jogo de relações. Os praticantes destes espaços dependem das instituições, as utilizam, as usam, são usuários. Os usuários têm de improvisar para viver na rede institucional, não contra suas regras, mas a partir delas. Como são perseguidos, cadastrados, vigiados e monitorados por sistemas digitalizados, câmeras, técnicas sanitárias, assistenciais, estatísticas e institucionais, são obrigados a lidar com estes tipos de relações que foram impostas e criadas para eles. Só que a realizam de outra maneira, a realizam da maneira que é possível. E nestes usos e apropriações, eles vão se “virando" (Gregori, 2003).

Há uma recusa muda em se identificarem como simples assistidos ou dependentes. Justamente por estarem subordinados às técnicas de interdição, inscrição e fixação devem ser astutos, espertos, burlá-las, saber navegar entre as regras, saber jogar com elas. As astúcias dos usuários são efetuadas por movimentos e operações plurais que mobilizam recursos insuspeitáveis, alterando e multiplicando as lógicas operantes na rede. Esta criatividade tática disseminada opera e joga no interior mesmo do dispositivo de poder. Tais práticas ordinárias, que se apropriam, desviam e deturpam a malha institucional, são justamente as linhas de fuga que enlaçam e repuxam a rede de atendimento, que a faz trabalhar e estabelecer outras lógicas de ação. E são estas contra-condutas e transgressões que atravessam a rede e são exercidas em meio a suas relações, que fazem todo esse aparato de controle funcionar. Tal aparelhagem funciona precisamente para dar conta destes fios soltos, dos deslocamentos ininterruptos, das inconsistências, incongruências e dispersões táticas.

\subsection{Como se gere uma população}

Michel Foucault considera a emergência da noção de população como uma das mutações mais importantes na história das sociedades modernas. Para o autor, é esta noção que libera a arte de governar, a desbloqueia. $O$ aparecimento da noção de população, na passagem do século XVIII para o século XIX na Europa, permite pensar o homem simultaneamente como espécie biológica, mas também como corpo que trabalha, que produz e que vive. Neste momento histórico foi colocado o problema de como gerir a população- 
riqueza, a população-mão-de-obra, e de como manter em equilíbrio seu crescimento a partir das fontes naturais de que se dispõe, como gerar o bem estar e a saúde desta população num meio que, cada vez mais, foi se urbanizando (Foucault, 1979, 2004).

Segundo Foucault, o surgimento da população não se deu como objeto de julgamento, para ser simplesmente condenada ou tolerada, ela nasce precisamente como uma questão de administração perante os poderes públicos, exige procedimentos de gestão e deve ser assumida por discursos analíticos e de saber. Para Foucault, a população é criada historicamente para ser gerida, mensurada, equiparada, diferenciada, classificada, protegida e otimizada. E neste processo, em particular, os seres vistos como desviantes e anormais vão se tornando um grande campo de ingerência, vigilância e disciplina (Foucault, 2002). Minha preocupação neste capítulo foi construir elementos capazes de apreciar as formas pelas quais a população de rua é regulada enquanto um domínio de gestão e segurança. Mas segurança em relação a quê?

Poderia afirmar que esta rede de proteção social diz respeito fundamentalmente ao risco imputado à experiência da rua. Contudo, é necessário afirmar que esta experiência, longe de ser um privilégio dos pobres, também é tida como necessária para o prosseguimento e o desenrolar da vida urbana como um todo (Berman, 2001). Através de tal suposto, se poderia apontar pelo menos duas importantes dimensões securitárias presentes na rede de atendimento à população de rua. Uma diz respeito à minimização dos riscos vivenciados por aqueles que não conseguem (ou dizem não querer) não viver nas ruas. Outra dimensão diz respeito à minimização dos riscos presentes nas próprias ruas e que são, mormente, atribuídos à população pauperizada que por ali circula. Esta última é mais problemática, visto que quase sempre aparece como dimensão secundária às práticas de auxílio e assistência social. Trata-se, portanto, da produção do risco através de uma retroalimentação circular: ao mesmo tempo em que o espaço público da rua é visto como um lugar perigoso e inadequado para a vida, as múltiplas figuras da pobreza que vivem e habitam neste espaço são vistas como as responsáveis pela insegurança e incivilidade do local. Em outras palavras: o mesmo dispositivo que busca proteger a população de rua, também tenta estabelecer mecanismos capazes de assegurar a rua do risco que é arrogado a esta população.

Entretanto, as coisas não são tão simples assim. Até porque, como vimos, esta rede de proteção é plena de falhas, faltas e interrupções. O atendimento é precário, assim como o trabalho desenvolvido por seus funcionários. Também, pelo que pude perceber em campo, ninguém parece muito satisfeito com o atual estado de funcionamento desta rede: nem seus usuários, nem seus funcionários e tampouco o poder público municipal. Este último 
constantemente quer saber "quantos moradores de rua conseguiram a autonomia", cobra "resultados efetivos" das instituições conveniadas, resultados que quase nunca são alcançados. Mesmo sem os objetivos desejados serem atingidos, é importante ter em conta que esta rede institucional produz efeitos e impactos reais na vida cotidiana de uma multiplicidade plural de subjetividades.

Um destes efeitos é que a dilatação deste campo institucional, tendo como peça fundamental o albergue, implicou no crescimento do próprio fenômeno população de rua. $\mathrm{Ou}$ seja, esta complexa rede de instituições, serviços, sistemas, registros e agentes, ao estender-se, permitiu, também, a ampliação de seu público-alvo. Esta política, ao buscar nas instituições semi-fechadas a possibilidade de "autonomia" da população de rua, possibilitou a configuração de um novo e inusitado quadro de dependência institucional. Aí se coloca um outro efeito perverso do dispositivo: não só a produção acelerada daquilo que se chama de população de rua, mas também a dependência desta população em relação à rede de serviços.

Sabe-se muito bem que nos dias atuais a abertura de um novo serviço de auxílio encontra sempre uma clientela carente, que rapidamente se adapta às formas de assistência (Castel, 1993). No caso do albergue, isto aparece de modo explícito. Instituição que surgiu como uma estadia provisória e emergencial, e tornou-se uma "moradia permanente" para um grande número de pessoas. Apesar de não ser permitido que um usuário de albergue permaneça mais de seis meses em seu interior, isso também é driblado, tanto pelos assistentes, quantos pelos usuários. No caso dos primeiros, estes muitas vezes, são colocados em delicadas posições de ter de decidir sobre o futuro da vida de pessoas que chegam na instituição, pessoas que muitas vezes chegam sem memória, sem documentos e sem capacidade física de locomoção. Estes, "vão ficando no albergue até a gente ver o que pode fazer", como me explicou uma assistente. Por outro lado, as astúcias dos usuários driblam o tempo limitado de permanência na instituição, esgotando o tempo limite, mudam-se para outro albergue, ou então vão para a rua, para mais à frente retornar à instituição. A circulação itinerante e diária entre os equipamentos são as próprias derivas nas quais estes sujeitos constituem-se e fundam-se. Há uma intensa e contínua circulação entre diferentes instituições. Certa vez numa conversa um usuário de albergue tentou-me convencer de sua "teoria dos oito anos", na qual seria possível viver este período de tempo sem precisar pagar aluguel e alimentação, apenas "pulando" de instituição em instituição. A proliferação dos albergues inegavelmente permitiu a emergência de uma nova forma de "estar nas ruas".

Nas conversas com os funcionários que trabalham no sistema albergal, explicaram-me que quando alguém "novo" entra na instituição, todo o esforço das assistentes é para que ele 
saia o mais "rápido possível”. Isso, pois, como me explicou uma assistente, "o usuário tende a acomodar-se porque não encontra nenhuma oportunidade na sociedade. Aí ele fica acomodado e vivendo apenas daqueles mínimos sociais". Apesar do discurso da "acomodação assistencial" também ser um elemento muito presente neste universo, vale apenas apontar para o fato de que os benefícios adquiridos por estes usuários limitam-se precisamente aos mínimos sociais. Como outra coordenadora de um albergue explicou: "existem os mínimos sociais e o albergue é o mínimo do mínimo. Agora, o albergue não pode ser tão ruim que a pessoa não queira entrar, e não pode ser tão bom a ponto da pessoa não queira sair". E é precisamente no limite entre a boa e má qualidade do atendimento e serviço, que estes usuários desenvolvem suas práticas.

É também neste limite, que a figura do albergado apresenta-se com maiores contornos. Muitos usuários se recusam a serem chamados de população de rua, agenciando, para tal, a categoria albergado de forma a reforçarem uma distância social, no interior de um espaço marcado pela intensa proximidade física. Neste circuito também ouvi muitas reivindicações sobre a necessidade de melhorias internas ao albergue. Estas reclamações, que se voltavam unicamente para fatores internos à instituição, talvez também demonstrem os vínculos de dependência com a instituição, e de como é baixa a expectativa, por parte de algumas pessoas, de abandonar algum dia o sistema albergal.

Esta relação de dependência, reconhecida e ao mesmo tempo criticada, tanto por usuários quanto por funcionários, apresenta-se de várias maneiras. Contudo, a fala de uma pessoa, que se definia como albergado, talvez apresente uma explicação mais simplificada da questão: "o maior problema não é entrar no albergue, isto é fácil. O mais difícil é sair do albergue". Sem dúvida a expressão "ciclo infernal" - evocada em momentos distintos e por diversas vozes no decorrer do trabalho de campo - anuncia o caráter, ao mesmo tempo cíclico da dependência e sua dimensão trágica. Assim, podemos ver como uma política social que busca encontrar "portas de saída" para a situação de rua, parece estar tornando-se, também, uma "porta de entrada" para essa situação. Ainda mais porque, ao entrar no albergue e ser cadastrado, o albergado é classificado automaticamente pelo SISRUA como pessoa em situação de rua.

Vemos aí como este dispositivo de proteção social, que busca a "emancipação" dos indivíduos que constituem esta população de rua, pode estar produzindo uma situação até então inédita de privação e vulnerabilidade social. Como diz Foucault a respeito dos efeitos perversos dos mecanismos dos dispositivos de proteção social: "por um lado, dá-se mais segurança às pessoas e, por outro, aumenta-se sua dependência” (Foucault, 2004b:127). Tal 
ambivalência, se levada ao extremo, induziria àquilo que Robert Castel - em um livro intitulado "A insegurança social: o que é ser protegido?" (2005) -, chamou de "frustração securitária”, visto que os complexos programas que se constroem em busca da proteção jamais podem ser plenamente cumpridos. Castel afirma que a multiplicação destes dispositivos de proteção possui, em seu reverso, justamente a explosão da sensação de risco (Castel, 2005). A noção de risco, por sua vez, é uma complexa construção que no período atual tem se consubstanciado também em alvo de gestão, mensuração e controle. Sendo considerado como resultante de uma fusão de "fatores" impessoais, sua prevenção moderna é, antes de tudo, caracterizada pelo mapeamento de riscos (Rabinow, 2002).

Assim, outro efeito relativo à multiplicação destes espaços institucionais semifechados diz respeito também ao risco, contudo, não mais daquele experimentado pelos corpos e subjetividades que se expõem e sobrevivem nas ruas. Trata-se da segurança da própria rua. Como artefato urbano, conectado a uma rede de procedimentos de proteção e controle, o albergue parece oferecer um eficiente instrumento de apoio na diária tarefa de desaglomeração e desobstrução do espaço público do centro paulistano. Sua função estratégica na rede de atendimento também se realiza devido à possibilidade de oferecer simultaneamente proteção e um local imediato para onde se enviar aquelas vidas que estão em constante deslocamento, e que são alvos das intervenções e expulsões do espaço público, pelas forças da ordem. Também, como os pedidos de retirada e remoção dos personagens que habitam tais espaços são constantes, é necessário que haja algum sítio fixo para onde remeter tais seres desaprovados socialmente como impuros, sujos, e, por isso mesmo, perigosos.

Através dos estudos pioneiros de Mary Douglas (1986), sabe-se das intrincadas relações existentes entre segurança, significação e ordem social. Esta autora, através de investigações antropológicas sobre tabu e poluição, demonstrou como a noção de perigo é resultante de processos e construções socioculturais, também o sendo, as impressões que tal noção carrega consigo, tais como: medo, ameaça e culpa. Este último elemento é importante, pois é através da culpa que alvos específicos - pessoas, grupos, países, categorias e coisas podem ser acusados como responsáveis por um determinado perigo assumido. Entretanto, na experiência urbana contemporânea, tais termos e suas relações, parecem ter adquirido um papel mais fundamental ainda, visto que vários autores têm apontado para os profundos nexos discursivos, securitários e acusatórios, que atualmente se articulam em torno de temas como criminalidade e pobreza (Marques; Telles; Miraglia; Montes, 2006).

Segundo Teresa Caldeira, o medo e a insegurança seriam componentes discursivos que estariam alterando significativamente não só as formas de interação social desenvolvidas na 
cidade, mas, também, inflectindo fortemente sobre o modo pelo qual o espaço urbano é produzido e organizado. Com isso, o próprio padrão de segregação paulistano estaria adquirindo uma feição distinta daquela articulada unicamente entre os termos binários centroperiferia (Caldeira, 2003). Para a autora, o aumento da pobreza urbana, sua distribuição mais diversificada no território da cidade, a maior proximidade física entre classes sociais distintas e o crescimento generalizado da sensação de medo e insegurança são fenômenos conectados e que estariam apontando para uma reorganização do espaço urbano, pautada fundamentalmente pelo reforço da discriminação, separação e divisão social, bem como na difusão de novas tecnologias de controle de modo a reiterar a desigualdade já existente: "Diferentes classes sociais vivem mais próximas umas das outras em algumas áreas, mas são mantidas separadas por barreiras físicas e sistemas de identificação e controle" (Caldeira, 2003:255). Esta proliferação dos aparatos técnicos teria como efeito primordial o fortalecimento das fronteiras que separam as classes sociais de modo a assegurar o medo disseminado e atribuído à experiência urbana do espaço público, um espaço supostamente inseguro, pois dominado pelos agentes da violência: os pobres, os miseráveis e outras sociabilidades marginais tidas como "fora de lugar" (Arantes, 2000).

Em seu argumento, Caldeira insiste que este novo padrão de segregação teria, nos enclaves fortificados, seu ícone máximo. Assim, a multiplicação dos condomínios fechados e de luxo, nas áreas antigamente consideradas como de domínio exclusivo dos pobres, é apresentada como expressão mais clara da emergência de uma cidade de muros. Entretanto, levando a sério a maior diversificação do tecido urbano paulistano e suas distintas configurações de desigualdade, outros autores têm atentado para o fato de que esta transformação no padrão de segregação sócio-espacial deve ser mais matizada e explorada analiticamente através de outras experiências e situações urbanas, não só aquelas ligadas aos chamados enclaves fortificados (Frúgoli Jr., 1995; Marques; Torres, 2005; Telles, 2006).

Deste modo, parece-me que a instituição albergue é um fragmento do tecido urbano que deve ser levado mais a sério, visto que reforça e expressa espacialmente - por uma espécie de micro-segregação investida de sistemas informatizados e mecanismos de controle e assistência $^{86}$ - disparidades e desigualdades sociais que aparentemente não apresentam

\footnotetext{
${ }^{86}$ Sobre isto vale citar a sofisticada explicação que ouvi de um usuário sobre a experiência do albergue: "o albergue é como se fosse um campo de concentração semi-aberto. A gente fica aqui uma parte do dia e tem de seguir as regras e depois tem de ir embora passar o dia na rua sem fazer nada para, só mais tarde, voltar para comer e dormir". Tal interpretação "nativa" encontra fortes ressonâncias com as análises desenvolvidas por Louïc Wacquant a respeito das modernas "prisões da miséria". Ao comentar sobre a regulamentação institucional das parcelas pauperizadas do novo proletariado pós-fordista, na Europa Ocidental e Estados Unidos, este autor demonstra como este processo se efetua "principalmente por intermédio de dispositivos panópticos
} 
horizontes de reconciliação tangíveis. Assim, se é verdade que contemporaneamente tem havido um movimento nos quais as elites e classes mais abastadas tendem a abandonar a experiência do espaço público e seus supostos "males urbanos", buscando maior segurança no interior de condomínios fechados e localizados nas franjas da cidade, pode-se afirmar que o albergue talvez apresente, parcialmente, um movimento simétrico contrário. Sua crescente presença no centro paulistano reflete e acompanha um percurso nos quais os segmentos sociais mais pauperizados e desfavorecidos da região passam a buscar no interior destes espaços institucionais possibilidades de sobrevivência e vida. Nos dois casos, o efeito que se produz é uma distância em relação ao espaço da rua, porém ocorre que no caso do albergue, a resultante não é um maior afastamento para com os "males urbanos", é sim sua concentração e adensamento num reduzido, precário e vigiado espaço físico. No seio destas instituições, justapõem-se situações de vulnerabilidade e trajetórias de insucesso que se fazem acompanhar de uma acentuada heterogeneidade de origens. O albergue, como última saída e lugar de exílio antes de se ter de ir para rua, reagrupa pessoas cujas dificuldades de inserção econômica, familiar e escolar acabam por fazer que seus usuários nada tenham em comum senão sua paradoxal comum excomunhão.

Com isso, esta instituição apresenta-se como uma importante retaguarda no interior dos variados procedimentos de segurança, ordenação e limpeza da paisagem urbana do centro de São Paulo, visto que permite conter e esconder as consequiências sociais mais deletérias visíveis nesta região. Meu argumento aqui é simplesmente que talvez se deva dar maior atenção para este fenômeno, não o entendendo unicamente como a principal política pública de "inclusão social" para a população de rua, mas como uma prática que encontra ressonâncias diretas com os tempos da cidade. Isto, pois, o discurso do medo e insegurança incita a proliferação de novas formas de segregação que incidem sobre a identificação dos agentes acusados pela suposta deterioração e morte dos espaços públicos. Assim, junto com o sistema albergal, poderíamos citar outros artefatos urbanos que buscam manter afastados os seres sociais indesejáveis das ruas: cercamentos de árvores, instalação de grades embaixo de viadutos, instalação de esguichos d'água em marquises de edifício, colocação de correntes

cada vez mais sofisticados e intrusivos, diretamente conectados aos programas de proteção e assistência". Segundo Wacquant, este movimento não seria um privilégio dos países ditos centrais, mas um processo diretamente conectado às novas formas de gestão institucional da precariedade, disseminadas também em outras partes do mundo. Além disso, afirma que as populações pobres são colocadas por uma "supervisão ainda mais rígida e meticulosa, na medida em que as diversas burocracias encarregadas de tratar a insegurança social no cotidiano sistematizam sua coleta de informações, colocam seus bancos de dados em rede e coordenam suas intervenções. Sem esquecer de 'modernizar' seus procedimentos e suas modalidades de intervenção, de maneira a minimizar os 'riscos' colocados pelas populações das quais são encarregadas e a torná-las compatíveis com os dispositivos de segurança que se multiplicam em sua esteira” (Wacquant, 2001:122). 
fechando áreas de entrada de prédios, cercamentos das laterais das igrejas impedindo a construção de "malocas", os conhecidos bancos "anti-mendigos", também a rampa "antimendigo", gradeamento de praças e câmeras de vídeo na região central. Aqui, estas tecnologias e pedagogias do espaço urbano também possuem, como o alvo, os habitantes das ruas.

Apesar de estes artefatos "anti-mendigo" (maneira na qual a imprensa costuma referir a tais objetos) encontrarem-se espalhados pela região central da cidade, argumento que talvez seja a experiência albergal aquela que expressa, da melhor maneira, a dimensão segregadora presente nas práticas urbanas de gentrification. Isto porque, ao acumular e concentrar, num mesmo e restrito espaço, corpos e subjetividades que possuem em comum apenas sua despossessão, esta instituição reforça a desigualdade e a distância social, alimentando o sentimento de que tais sujeitos ali reunidos pertencem a mundos sociais separados de seu exterior. E tudo isto, na região da cidade historicamente marcada justamente pela mistura social e pelo contato inter-classes. Talvez seja interessante apenas lembrar que a mesma gestão municipal que se apropriou definitivamente do discurso da "requalificação" do centro e o colocou na agenda política, foi aquela que praticamente dobrou o número de albergues na cidade.

Talvez se compreenda melhor, assim, a transformação de uma política social que parece ter abandonado progressivamente a meta de reformar ou "reinserir" a população de rua e, em lugar disso, passou a se preocupar, mais e mais, em supervisionar suas vidas para que não atrapalhem ou transmitam insegurança à paisagem do Centro. Trata-se de gerir a população de rua de modo que sua aleatoriedade não atrapalhe o andamento das práticas na cidade. A reinserção parece ter se tornado uma questão no mínimo secundária, sendo que aquilo que salta em primeiro plano é justamente a produção de uma paisagem urbana supostamente protegida. Com isso, tentam assegurar o espaço da rua contra possíveis transgressões, numa luta minúscula e diária contra todas as pequenas incivilidades, infrações, distúrbios e infortúnios que possam ser vistos como "incubadores" do perigo, do risco social e da decadência moral. 


\section{Considerações finais}

A proposta deste trabalho foi descrever e analisar de perto alguns processos, acontecimentos e mecanismos parciais pelos quais a população de rua é constituída historicamente, contestada politicamente e regulada institucionalmente como questão social. Para isso, utilizando-me do conceito de dispositivo, apresentei cada capítulo da dissertação privilegiando uma das dimensões a serem analisadas, sendo que em nenhum deles busquei esgotar a problemática. Também propus que estes capítulos fossem entendidos não como totalidades, e sim como objetos etnográficos destacados de um incessante movimento de conjunto, a serem analisados como componentes operantes no interior de jogos de sentido e força.

No primeiro capítulo, apresentei, através de perspectivas entrecruzadas de atores situados, a trama de uma história na qual foi possível expor o nascimento da população de rua como uma questão social e seu campo de aparição na cidade de São Paulo. Tendo em conta a dificuldade de se escrever e descrever um complexo processo histórico como este, minha atenção voltou-se privilegiadamente para os sentidos adquiridos e construídos através das narrativas e trajetórias expostas.

No segundo capítulo, vimos como o fenômeno população de rua pôde manifestar sua dimensão política no espaço público da cidade. Ali foi possível entrever alguns modos pelos quais esta questão é publicizada, interrogada e contestada por variados agentes. Tendo em conta que os movimentos sociais estão envolvidos em jogos de verdade sobre si e sobre outros, nos rituais políticos enfocados dei destaque à forma pela qual o Movimento Nacional da População de Rua (MNPR) problematiza a si mesmo frente a outros movimentos e alteridades políticas.

No terceiro e último capítulo, apresentei a população de rua como um problema de gestão e segurança. Para isso expus sucintamente alguns componentes da rede de atendimento à população de rua, destacando a importância da instituição albergue nesta composição. Através do material etnográfico coletado e produzido no interior de um albergue e de outros equipamentos institucionais que tratam desta população, enfoquei as dimensões cotidianas vividas neste universo, tanto por aqueles que se utilizam destes serviços, quanto por aqueles que atuam neles.

Nos três capítulos, evitei definir a população de rua e, em lugar disso, preferi interrogar os modos pelos quais esta realidade é definida. Para isso, tive como principal 
referência a pergunta descritiva: “como?” Gostaria agora de apresentar, sucintamente, alguns argumentos finais.

Como vimos no primeiro capítulo, parte da linguagem que atualmente rege a interpretação do fenômeno começou a ganhar maior contorno através do esforço de alguns atores ligados a um imaginário político-religioso específico que, contudo, estava diretamente conectado às experiências urbanas vividas na passagem da década de setenta para oitenta em São Paulo. Não por acaso, as formas de inteligibilidade e abordagem construídas foram extraídas do próprio meio em que estes atores circulavam e estavam embebidos. Assim, as referências utilizadas nas primeiras formas de organização desta realidade - tais como a comunidade, a convivência e a missão -, bem como suas formas de nomeação - os sofredores de rua e o povo que quer viver - foram orientadas por valores eminentemente cristãos e católicos. Foi esta matriz discursiva que, num primeiro momento, serviu como ponto primário de referência para a construção da experiência de rua como foco de inquietação.

Já um tanto esquematicamente, poderíamos apresentar um segundo momento - situado no desenrolar da década de noventa e que irá consubstanciar-se formalmente apenas no limiar do novo século -, no qual esta experiência começa a se transformar e se institucionalizar como um campo de intervenção pública. E neste processo, sua matriz discursiva veio a ser apropriada e ajustada através de outros referenciais. A figura do Estado aparece mais fortemente, abrindo espaço para a participação de outros atores e organizações ligadas ao terceiro setor. Esta ampliação do campo implicou numa tendência a uma maior formalização das modalidades de intervenção e procedimentos então utilizados. Apesar da referência à "comunidade" permanecer ainda hoje neste campo discursivo, o modo como é agenciada diverge muito de antes. As ações sociais, "comunitárias" ou não, voltadas a esta realidade, articulam-se hoje mediante projetos sociais com parcerias, financiamentos e convênios públicos que, em quase todos os casos, regem e determinam os tipos de trabalho oferecido. Além disso, as próprias noções de "comunidade" e "convivência", enquanto importantes referências iniciais para a intervenção e organização deste universo, gradativamente foram deixadas de lado, de modo que hoje, a instituição-albergue tem se tornado o modo hegemônico de ação, bem como o principal eixo de ação estatal e pública sobre esta realidade.

Outro deslocamento que me parece relevante ser apontado no caso analisado, refere-se ao próprio sentido atribuído à rua. O tema da dor, agonia e do sofrimento, tão caro ao cristianismo e, de maneira geral, à própria história do Ocidente, foi sendo deslocado para a conhecida e mais mensurável noção de risco. Assim, a experiência de rua deixa gradativamente de ser uma experiência de sofrimento, transformando-se em situação de risco 
e insegurança. Também, o modo de nomeação dos seres que habitam as ruas parece ter se transformado significativamente. Cada vez menos se ouve falar em termos de povo - um povo que quer viver, o povo da rua, o povo em movimento - e mais aparece o uso técnico da categoria população - população de rua, população em situação de rua, população em situação de risco.

Este deslocamento, apresentado aqui de modo um tanto esquemático, de maneira alguma está concluído, mas, contudo, acena para uma importante transformação neste campo. Transformação pautada fundamentalmente por uma crescente racionalização e tecnicização dos modos de lidar com esta questão social. Um tipo de abordagem que se tende a ajustar, cada vez mais, por medições, números, probabilidades e resultados. Mas também vale apontar que os próprios atores engajados neste campo passam a utilizar e participar desta linguagem mais técnica, linguagem utilizada, inclusive, em suas críticas, reivindicações e lutas políticas.

No entanto, este deslocamento do tipo de intervenção efetuada sobre a questão social parece não ser privilégio da experiência de rua. Também outros estudos têm mostrado como a referência comunitária, historicamente produzida na periferia de São Paulo pelas CEBs, tem sido utilizada por meio de uma significativa alteração e reorientação de suas práticas anteriores, bem como no modo de regulação destas, em direção à busca de uma maior racionalidade no andamento dos programas sociais (Rizek, 2006). Assim, a despeito das enormes diferenças entre as trajetórias das Comunidades Eclesiais de Base, nas periferias da cidade, e as da Comunidade dos Sofredores de Rua, na "periferia do centro", é possível apontar semelhanças, que se referem menos a seus conteúdos específicos, e mais às transformações e relações históricas em que ambas se situam.

Robert Castel diz que a questão social sempre se armou em torno das figuras dos mais miseráveis, indigentes, mendigos, vagabundos e outros desafortunados. Contudo, também afirma que o modo pelo qual foram mobilizados e inventados dispositivos para resolver os desafios que estas figuras colocavam para intervenção, sempre esteve submetido às configurações históricas e suas metamorfoses (Castel, 1998). Através da noção de dispositivo, busquei demonstrar como a população de rua, ao fornecer um lugar para os não classificáveis, pôde ser reconhecida enquanto uma figura da pobreza destacada do mundo indiferenciado da miséria e penúria, em que até então tais personagens encontravam-se mergulhados. No interior de um universo indiscernível e dissolvido pela carência, certa realidade começou a ser recortada, delimitada e ganhar contornos mais nítidos. E, neste processo, passaram a ganhar atributos específicos, sendo identificados como uma classe de sujeitos especiais e vinculados primariamente ao universo da rua. Foi em torno destes sujeitos que se passou a montar feixes 
de questões, que foram se unificando e configurando relações sociais, desenhando formas de sociabilidade, articulando referências de identidade disponíveis e modos de reconhecimento público. No entanto, a definição da população de rua, vista sob uma categoria única, ao mesmo tempo em que permite montar um campo de problematização em que convergem motivações e atores variados, reabre a própria aporia pela qual foi armada, visto que sua unidade se apresenta como um estereótipo que termina por produzir algo como um desconhecimento sobre sua própria realidade múltipla.

Homi K. Bhabha chamou de estereótipo um modo ambivalente de conhecimento e poder. Seria o ponto primário de subjetivação no discurso, tanto para aquele que fala quanto para aquele que é falado: "O estereótipo não é uma simplificação porque é uma falsa representação de uma dada realidade. É uma simplificação porque é uma forma presa, fixa, de representação que, ao negar o jogo da diferença, constitui um problema para a representação do sujeito em significações de relações psíquicas e sociais" (Bhabha, 2003:117). É a força da ambivalência que dá ao estereótipo sua validade. Assim, a população de rua, precisamente por ser uma categoria vaga em sua definição e, mesmo assim, conseguir fixar, simplificar e negar o jogo da diferença que reside no bojo dos processos de identificação, opera como facilitadora, ou seja, constitui-se enquanto o próprio meio pelo qual se torna possível realizar ações em seu nome.

É o que acontece, por exemplo, quando um movimento social começa a se tornar porta-voz desta população e reivindicar seus direitos. Ou então, quando o Estado desenvolve práticas políticas para fazer valer os direitos desta população. Nos dois casos, o discurso estereotípico é acionado, no entanto, os modos pelos quais este se dá é distinto, senão conflituoso e antagônico. Isto apenas para lembrar que, a mesma resolução nominal que permitiu a articulação de um sujeito político, também permitiu a instalação de toda uma aparelhagem para proteção, reinserção e controle destes mesmos sujeitos na cidade de São Paulo. Contudo, tanto a constituição de um movimento social em escala nacional, bem como a possibilidade de se construir uma política federal para a população de rua (visto que hoje um Comitê Interministerial desenvolve trabalhos nesta direção), acenam para a crescente magnitude do fenômeno, mas também para seus desafios.

Se, no início da década de noventa, no discurso inaugural sobre esta realidade enquanto um fenômeno de população ${ }^{87}$, sua causa pôde ser definida primordialmente através

\footnotetext{
${ }^{87}$ Refiro-me aqui às discussões iniciadas na gestão municipal de Luiza Erundina e que se estão registradas na obra População de rua: quem é, como vive, como é vista (Vieira; Bezerra; Rosa, 1994), mas também em População de rua: Brasil e Canadá (Rosa, 1995b).
} 
do critério do trabalho ou, mais precisamente, sua ausência, a nomeação da questão passa necessariamente pelo critério da moradia, visto que seu lócus de aparição é a rua. Assim, se o maior problema visível é simplesmente o "morar na rua", as ações políticas acabam por voltar-se, preferivelmente, para a solução tópica deste problema, com a crescente criação de espaços institucionais funcionando como "abrigos emergenciais".

Quanto a isso, aponto apenas para o fato de que a instituição-albergue parece constituir-se enquanto uma modalidade extremamente problemática de intervenção neste universo. No caso de São Paulo, sua proliferação produziu uma situação paradoxal, possibilitando a criação de verdadeiras "formas de vida assistidas", que territorializam suas existências sobre a tênue linha dos mínimos sociais forçosamente distribuídos pelo Estado. Entretanto, mais problemática do que a existência de um gênero de vida albergal - o albergado -, é a continuação desta política como principal carro chefe das ações de "inclusão social" para a população de rua, e todas as categorias que esta, porventura, possa abarcar. Devido ao número de instituições já instaladas no centro expandido da cidade (cerca de 26), bem como as formas de vida que a acompanham (estima-se que sejam mais de 7 mil), a desativação destes equipamentos parece ser algo inviável. No entanto, o trágico é tomar tal política como se fosse a única possibilidade de ação, sendo que tais práticas foram historicamente contestadas e que outras possibilidades de trabalho permanecem abertas nos dias de hoje ${ }^{88}$.

A proliferação destes equipamentos levou à constituição de novos sujeitos - os albergados -, uma identidade fugidia e fugaz que possui como ponto primário de subjetivação a própria instituição. Contudo, tal categoria também permanece por funcionar como uma sombra que obscurece uma realidade multifacetada, e que carrega uma questão ainda mais preocupante: a presença cada vez mais maciça de categorias de população que até então não se misturavam tão intensamente num mesmo espaço institucional, como, por exemplo, "loucos", “doentes", “drogados”, “idosos" e "deficientes físicos”. Talvez esta preocupação seja exagerada, já que no Ocidente a psiquiatria e a medicina sempre se confundiram um pouco com as formas de assistência. Contudo, esta inquietação ao menos aponta para a atual forte interdependência entre o problema "social", o "psiquiátrico" e o da "saúde" manifesto no circuito das ruas no centro de São Paulo. Não obstante, se levarmos a sério a falta de especificidade do público atendido pelo albergue - que é decorrente também da própria

\footnotetext{
${ }^{88}$ Sobre as possibilidades e dificuldades relativas à desinstitucionalização da assistência social, bem como os limites das intervenções albergais para a população de rua, ver respectivamente Lancetti (1993) e Rosa (1994).
} 
dificuldade em definir a população de rua, mas que também é conseqüência da transformação histórica de sua definição -, não estaríamos arriscados a voltar àquele momento histórico do Ocidente, em que todas as técnicas e tecnologias sociais eram mais ou menos indiferenciadas, como nos fala Foucault? Não estaríamos re-atualizando, em novos tempos de acumulação pós-fordista, o "grande internamento" que precedeu a psiquiatria, os asilos, as prisões e a assistência profissionalizada? Da mesma maneira como é possível observar no interior dos albergues da cidade de São Paulo, também o "grande internamento" chegou a congregar num mesmo espaço de reclusão as várias categorias de "pobres", "trabalhadores sazonais", "loucos", “doentes", "prostitutas", "libertinos" e "foras da lei”.

Contudo, se é verdade que todas as instituições da modernidade tinham por finalidade não excluir, mas, ao contrário, fixar os indivíduos para ligá-los a aparelhos de produção, correção e normalização (Foucault, 2001), parece que a finalidade do albergue tem sido outra, ou pelo menos parcialmente outra. Isto porque, a "inclusão e reinserção social" que tanto se deseja, dificilmente se realiza. Assim, a pergunta que fica na cabeça dos gestores públicos, dos assistentes sociais, educadores, agentes religiosos, lideranças e estudantes (para, assim, retornar à primeira questão colocada logo na introdução deste trabalho) é justamente: "o que fazer?" 


\section{Referências bibliográficas}

\subsection{Bibiografia geral}

Agier, M., L'invention de la Ville: Banlieues, townships, invasions et favelas, Paris: éditions des archivest contemporaines; 1999.

Augé, M., Não-Lugares: Introdução a uma antropologia da supermodernidade. São Paulo: Editora Papirus; 1992.

Barth, F., "Grupos étnicos e suas fronteiras", In: Teorias da Etnicidade, (org. Poutignat, P.; Jocelyne, S.), São Paulo: Unesp; 1998.

Bakhtin, M. (Volochínov) Marxismo e filosofia da linguagem, São Paulo: Hucitec; 2006.

Belinck, M. Marginalidade social e relações de classes em São Paulo: Vozes; 1977.

Bermam, M. Tudo que é sólido desmancha no ar. São Paulo: Companhia das Letras; 2001.

Bhabha, H. K. O Local da Cultura, Belo Horizonte, UFMG, 2003.

Bourdieu, P., A Economia das Trocas Lingüísticas, São Paulo, Edusp; 1996.

, O Poder Simbólico. Rio de Janeiro: BCD União de Editoras; 2001. , “A codificação”, In: Coisas Ditas, São Paulo: Brasiliense; 2004. , “A Ilusão Biográfica”, In: Ferreira, M. M. e Amado, J. (org.). Usos e Abusos da

História Oral, Rio de Janeiro: Fundação Getúlio Vargas; 2005.

Cabannes, R. "Espaço público e espaço privado: o jogo de suas relações”, In: Telles, V. S. \& Cabanes, R. (orgs.) Nas tramas da cidade: trajetórias urbanas e seus territórios, São Paulo: Humanitas; 2006.

Cardoso, R. "Movimentos sociais na América Latina”, Revista Brasileira de Ciências Sociais, n 3, vol. 1, fev. de 1987 .

Caldeira, T. A política dos outros: cotidiano dos moradores da periferia e o que pensam do poder e dos poderosos, São Paulo: Brasiliense; 1989.

, Cidade de muros - crime, segregação e cidadania em São Paulo, São Paulo: 34 / Edusp; 2003.

Castel, R. As metamorfoses da questão social - uma crônica do salário, São Paulo: Vozes; 1998.

Clifford, J., A experiência etnográfica: antropologia e literatura no século XXI, Rio de Janeiro: UFRJ; 2002. 
, “Culturas Viajantes”, In: Arantes, A. Antonio (org), Espaço da diferença, São

Paulo: Papirus; 2000.

de Certeau, M., A Invenção do Cotidiano 1. Artes de fazer, Petrópolis: Vozes; 2003. , “Teoria e Método no estudo das práticas cotidianas", In: Cotidiano, Cultura

Popular e Planejamento Urbano (org.). Szmrecsanyi, M. I., Seminário da Faculdade de Arquitetura e Urbanismo de São Paulo,1982.

Deleuze, G. Foucault, São Paulo: Brasiliense; 2005.

Deleuze, G. e Guattari, F., "Tratado de Nomadologia: a Máquina de Guerra” In: Mil Platôs: Capitalismo e Esquizofrenia, v. V, São Paulo: Editora 34; 2002.

"Micropolítica e segmentaridade", In: Mil Platôs: Capitalismo e

Esquizofrenia, v. III, São Paulo: Editora 34; 2004

Desrosière, A. "Discutir o indiscutível", In: Raison Pratiques, no 3 - "Pouvoir et legitime. Figures de 1'espace public”, Paris: EHESC; 1993 (Tradução de Vera Telles para circulação interna).

Douglas, M. Pureza e Perigo. São Paulo: Perspectiva; 1986.

Durham, E. A caminho da cidade. São Paulo: Brasiliense; 1985.

.A pesquisa antropológica com populações urbanas”. In: A aventura antropológica, Rio de Janeiro: Paz e Terra; 1997.

Durham, E. "Movimentos sociais: a construção da cidadania", In: A Dinâmica da Cultura: ensaios de antropologia (org.) Thomaz, O. R., São Paulo: Cosac\&Naify; 2004.

Elias, N.; Scotson, L. Os estabelecidos e os outsiders, Rio de Janeiro: Zahar; 2000.

Evers, T. "Identidade - A face oculta dos novos movimentos sociais", Novos Estudos CEBRAP no 4, abr. de 1984.

Ferguson, J; Gupta, A., "Mais além da 'Cultura': Espaço, Identidade e Política da Diferença”, In: Arantes, A. Antonio (org), Espaço da diferença, São Paulo: Papirus; 2000.

Fonseca, C. "La clase social y su recusación etnográfica”. In: Etnografías contemporáneas, 1 (1), Universidad Nacional de San Martin, p. 117-138, 2005.

Foucault, M. "O Sujeito e o Poder”. In: Rabinow, P. \& Dreyfus, H., Michel Foucault: Uma Trajetória Filosófica, São Paulo: Forense Universitária; 1995.

, Vigiar e Punir: Nascimento da prisão, Petrópolis: Vozes; 2001a.

, Microfísica do Poder. Rio de Janeiro: Graal; 2001b.

, História da Sexualidade 1: A Vontade de Saber, Rio de Janeiro: Graal; 2001c.

, História da sexualidade 2: O uso dos prazeres, Rio de Janeiro; Graal; 2001d. 
, A verdade e as formas jurídicas, Rio de janeiro: NAU; 2002a.

, Os Anormais, São Paulo: Martins Fontes; 2002b.

, Securité, territoire, population, Paris: Seuil/Gallimard; 2004.

_, "Um sistema finito diante de um questionamento infinito", In: Foucault -

Ética, Sexualidade, Política, Ditos \& Escritos, Vol. V, Rio de Janeiro: Forense; 2004b

, O Poder Psiquiátrico, São Paulo: Martins Fontes; 2006.

, Entrevistas (org.) Pol-Droit, R. São Paulo: Graal; 2006b.

, “A vida dos homens infames", In: Foucault - Estratégia, Poder-Saber, Ditos

\& Escritos Vol. IV, Rio de Janeiro: Forense; 2006c.

Frehse, F., O Tempo das Ruas: Na São Paulo de fins do Império, São Paulo: EDUSP; 2005.

Frúgoli, Jr., H. São Paulo: Espaços Públicos e Interação Social. São Paulo: Marco Zero; 1995.

Centralidade em São Paulo: trajetórias, conflitos e negociações na Metrópole, EDUSP, 2000.

, "O urbano em questão na antropologia: interfaces com a sociologia", In:

Revista de Antropologia, v.48, n.1, São Paulo: USP; 2005a.

, Sobre o alcance do conceito de gentrification para pensar sobre intervenções urbanísticas em áreas centrais de cidades brasileiras: o caso de São Paulo. Texto apresentado no "primeiro Congreso Latino Americano de Antropologia", (Rosário, 11 a 15 de julho de 2005), no Simpósio “Ciudad y ciudades”, 2005 b.

Frúgoli Jr., De Lucca, Daniel \& Aquino, Carlos, Quadro recente dos conflitos sociais no centro de São Paulo: o movimento de luta por moradia e a população em situação de rua, Texto produzido para ser apresentado na $25^{\mathrm{a}}$ Reunião Brasileira de Antropologia (Goiânia, 11 a 14 de junho de 2006), no GT “A cidade e seus lugares: práticas e representações".

Geertz, C. "O pensamento como ato moral: dimensões éticas do trabalho de campo antropológico nos países novos”, In: Nova Luz sobre a antropologia, Rio de Janeiro: Zahar; 2001.

Goffman, E. Manicômios, Prisões e Conventos. São Paulo: Perspectiva; 1974.

Grafmeyer, Y. Sociologia Urbana, Lisboa: Europa-América; 1995.

Gribaldi, M. "Escala, pertinência, configuração", In: Revel, J. (org). Jogos de Escala; A experiência da microanálise, Rio de Janeiro: Fundação Getúlio Vargas; 1998. 
Guattari, F., "Espaço e Poder: a criação de territórios na cidade" in: Espaço e Debates, No. 16, São Paulo: 1985.

Hannerz, U., Exploring the City: Inquiries Toward an Urban Antropology. NY: Columbio University Press; 1980.

"Fluxos, Fronteiras, Híbridos: Palavras-chaves da Antropologia Transnacional", Mana, Abril, 1997, vol. 3, n. 1.

Conexiones Transnacionales: Cultura, gente, lugares. Madrid: Ediciones Cátedra; 1998.

Haraway, D., "Saberes Localizados: a questão da ciência para o feminismo e o privilégio da perspectiva parcial”, In: Cadernos Pagu (5), 1995: pp. 07-41.

Harvey, D., Do administrativismo ao empreendedorismo: a transformação da governança urbana no capitalismo tardio, In: A Produção Capitalista do Espaço, São Paulo: Annablume; 2005.

, Condição pós-moderna, São Paulo: Loyola; 2002.

Huizinga, J., Homo Ludens - O jogo como elemento da cultura, São Paulo: Perspectiva; 2004.

Joseph, I. "A respeito do bom uso da Escola de Chicago", In: (org.) Valladares, L. P., A Escola de Chicago: Impacto de uma tradição no Brasil e na França, Rio de Janeiro: UFMG/IUPERJ; 2005.

Erving Goffman e a microssociologia, Rio de Janeiro: FGV; 2000.

Laclau, E. "Os novos movimentos sociais e a pluralidade do social", Revista Brasileira de Ciências Sociais, $\mathrm{n}^{\circ}$ 2, vol. 1, out. de 1986.

Laclau, E.; Mouffe, C. Hegemonia y estratégia socialista - Hacia uma radicalización de la democracia, Buenos Aires: Fondo de Cultura Econômica; 1986.

Latour, B. "Faktura da noção de rede à de vinculação", 2000 (tradução de Vera Telles para circulação interna).

Leal, A. Bruno Latour e Michel Foucault: entre a construção de um mundo comum e a ontologia histórica de nós mesmos, In: Queiroz, A. \& Cruz, N. (org.) Foucault Hoje?, Rio de janeiro: 7 letras; 2007.

Levi, Giovanni. "Usos da Biografia", In: Ferreira, M. M. e Amado, J. (org.). Usos e Abusos da História Oral, Rio de Janeiro: Fundação Getúlio Vargas; 2005.

Loriga, S. "A biografia como problema”, In: Revel, J. (org). Jogos de Escala: A experiência da microanálise, Rio de Janeiro: Fundação Getúlio Vargas; 1998. 
Kofes, S., "Experiências Sociais, Interpretações Individuais: Histórias de Vida, suas possibilidades e limites”, In: Cadernos Pagu (3) 1994: pp. 117-141.

Kowarick, L. et alii. São Paulo 1975: crescimento e pobreza. São Paulo: Loyola; 1976.

Kowarick, L. A espoliação urbana, São Paulo: Paz e Terra; 1993.

Escritos urbanos, São Paulo: 34; 2000.

Levi, G., "Usos da Biografia", In: Ferreira, M. M. e Amado, J. (org.). Usos e Abusos da História Oral, Rio de Janeiro: Fundação Getúlio Vargas; 2005.

Lepetit, B., Por Uma Nova História Urbana (org.). Salgueiro, H. A., São Paulo: EDUSP; 2001, pp. 137-153.

Lourau, R., “Objeto e método da Análise Institucional”, In: Analista Institucional em tempo integral (org.). Altoé, S., São Paulo: Hucitec; 2004, pp. 66-86.

Marcus, G. "Ethnography in/of the Word System: The Emergence os Multi-Sited Ethnography”, In: Annual Review Anthropology, n. 24: 1995.

Marques, E.; Torres, H. (Org.) São Paulo: segregação, pobreza e desigualdades sociais, São Paulo: Senac; 2005.

Nakano, K., Candido, M. e Rolnik, R., "Dinâmicas dos subespaços da área central de São Paulo", In: Empresa Municipal de Urbanização - EMURB, Caminhos para o Centro: Estratégias de desenvolvimento para a Região Central de São Paulo, SP; 2004.

Perlman, J. O mito da marginalidade, Rio de Janeiro: Paz e Terra; 1977.

Perlongher, N. “Territórios Marginais”, In: Papéis Avulsos, n. 6, Rio de Janeiro; 1989. Rabinow, P. Antropologia da Razão. Rio de Janeiro: Relume Dumará; 2002.

Rabinow, P; Dreyfus, H. (org.), Michel Foucault: Uma Trajetória Filosófica, São Paulo: Forense Universitária; 1995.

Rago, M., Do Cabaré ao Lar: A Utopia da Cidade Disciplinar, Brasil: 1890 - 1930, Rio de Janeiro: Paz e Terra; 1985.

Revel, J., "Jogos de papéis sociais", In: A invenção da sociedade, Rio de Janeiro: Bertrand Brasil/Difel; 1989a.

"Microanálise e Construção do Social”, In: Revel, J. (org). Jogos de Escala: A experiência da microanálise, Rio de Janeiro: Fundação Getúlio Vargas; 1998b.

Rosental, P. “Construir o 'macro' pelo 'micro': Fredrik Barth e a 'microstoria'”, In: Revel J. (org.), Jogos de Escala: A experiência da microanálise, Rio de Janeiro: Fundação Getúlio Vargas; 1998. 
Rosenthal, G., "A Estrutura e a Gestalt das autobiografias e suas conseqüências metodológicas", In: Ferreira, M. M. e Amado, J. (org.). Usos e Abusos da História Oral, Rio de Janeiro: Fundação Getúlio Vargas; 2005.

Sader, E., Quando novos personagens entram em cena, São Paulo: Paz e Terra; 1988.

Sader, E.; Paoli, M. "Sobre classes populares no pensamento sociológico brasileiro", In: A aventura antropológica, Rio de Janeiro: Paz e Terra; 1997.

Silva, L.; Ribeiro, T. "Paradigma e movimento social: por onde andam nossas idéias?", Ciências Sociais Hoje, Cortez; 1985.

Singer, P.; Brant (org.) São Paulo: o povo em movimento, São Paulo: Vozes/CEBRAP; 1976.

Smith, N. "Geografia, diferencia y las políticas de escala", In: Terra Livre, Ano 18, n. 19, P. 127-146, jul./dez. 2002.

, "Contornos de uma política espacializada: veículos dos sem-teto e produção de escala geográfica”. In: Arantes, AA (org). O Espaço da diferença. São Paulo: Papirus; 2000.

The new urban frontier - Gentrification and the revanchist city, New York:

Routledge; 1996.

Swyngedouw, E. "A cidade como híbrido: natureza, sociedade e "urbanização-cyborg”", In: Acselrad, H. (Org.) A Duração das cidades. Rio de Janeiro: DP\&A; 2001.

Telles, V. S. \& Cabanes, R. Nas tramas da cidade: trajetórias urbanas e seus territórios, São Paulo: Humanitas; 2006.

Telles, V. S., "Medindo Coisas, produzindo fatos, construindo realidades sociais", Comunicação do seminário internacional sobre indicadores sociais para inclusão social, Núcleo de Estudos e pesquisas em seguridade e assistência social do programa de Estudos Pós-Graduados da PUC-SP, 15 e 16 de Maio de 2003, PUC-SP, (no prelo).

Thompson, P., A Voz do Passado: História Oral, São Paulo: Paz e Terra; 2002.

Wacquant, L., As prisões da miséria, Rio de Janeiro: Jorge Zahar; 2001.

Zaluar, A. "Teoria e prática do trabalho de campo: alguns problemas". In: A aventura antropológica, Rio de Janeiro: Paz e terra; 1997.

\subsection{Bibliografia específica}

Barros, J. S., Moradores de rua - Pobreza e Trabalho: interrogações sobre a exceção e a experiência política brasileira, Dissertação de Mestrado do Departamento de Sociologia da Faculdade de Filosofia Letras e Ciências Sociais-Univesidade de São Paulo, 2004. 
Bastos, C.; Toseli, C.; Aquino Jr., F.; Bove, M.; Oliveira, M.; Manoel, R. Pastoral da Rua: Vida e Missão. São Paulo: Edições Loyola; 2003.

Bursztyn, M. Da utopia à exclusão - Vivendo nas ruas em Brasília. Brasília: Codeplan; 1997.

Castelvecchi G. (Nenuca). Quantas vidas eu tivesse, tantas vidas eu daria! São Paulo: Edições Paulina; 1985.

De Lucca, D. "Márgenes en el Centro: calle, catación y basura en el centro de São Paulo", In: Schambler, P. \& Suárez, F. (org.). Recicloscopio: Miradas sobre recuperadores urbanos de residuos de America Latina. Buenos Aires: UNGS/UNLa; 2007.

Domíngues Jr, P. L., Cooperativa e a construção da cidadania da população de rua, São Paulo: Edições Loyola; 2003.

Escorel, S. Vidas ao léu: trajetórias de exclusão social. Rio de Janeiro: Fio Cruz; 1999. FIPE/Secretaria Municipal de Assistência Social. Censo dos moradores de rua da cidade de São Paulo. São Paulo, Prefeitura do Município de São Paulo, 2000.

FIPE/Secretaria Municipal de Assistência Social. Recenseamento dos moradores de rua da cidade de São Paulo. São Paulo, Prefeitura do Município de São Paulo, 2003.

Frangella, S. M. Corpos urbanos errantes: uma etnografia da corporalidade de moradores de rua em São Paulo. Tese de doutorado, DA-IFCH-UNICAMP, Campinas, 2005.

Fórum Centro Vivo, Violações dos direitos humanos no centro de São Paulo - propostas e reivindicações para políticas públicas, Dossiê de denúncia, São Paulo: 2006.

Giorgetti, C. Moradores de rua - Uma questão social?. São Paulo: PUCSP-EDUC; 2006.

Gregori, M. F. Viração: Experiências de meninos nas ruas. São Paulo: Companhia das Letras; 2001.

Magni, C. T. Nomadismo Urbano: uma etnografia sobre moradores de rua em Porto Alegre. Porto Alegre: EDUNISC; 2006.

Marques, E., Torres, H. São Paulo: segregação, pobreza e desigualdades sociais, São Paulo; Editora Senac: 2005.

Marques, E.; Telles, V.; Miraglia, P.; Montes, M. "Pobreza e criminalidade”, In: Sexta feira n 8 - Periferia, São Paulo: 34; 2006.

Nasser, A. Sair para o mundo: trabalho, família e lazer na vida dos excluídos. São Paulo: Hucitec; 2001. 
Nova Pesquisae assessoria em Educação \& Fórum de Estudos sobre População de Rua. Textos em debates 3 - Fórum de estudos sobre População de rua: Avanços e Desafios. Rio de Janeiro: Nova; 1998.

OAF (Organização do Auxílio Fraterno). Somos um povo que quer viver. São Paulo: Edições Paulinas; 1982.

Oliveira, M. Entre ruas, lembranças e palavras: a trajetória dos catadores de papel em Belo Horizonte. Belo Horizonte: PUCMINAS; 2005.

Rosa, C. M. M., Vidas de rua, destinos de muitos. São Paulo, Hucitec/Associação Rede Rua, 2005 (Estudos Brasileiros, no 37).

, Vidas de rua, destinos de muitos. Pesquisa em jornais e revistas sobre temas relativos a população de rua na cidade de São Paulo: 1970-1998. São Paulo: IEE/PUC-SP, 1999. (CD-Rom) , (org) População de rua: Brasil e Canadá, São Paulo: Hucitec; 1995 b.

Schambler, P. \& Suárez, F. (org.). Recicloscopio: Miradas sobre recuperadores urbanos de residuos de America Latina. Buenos Aires: UNGS/UNLa; 2007.

Secretaria Municipal de Assistência Social. População de Rua tem seus direitos garantidos. Lei 120316/97 - Decreto 40.232/Serviços de Atenção, 2001.

Snow, D.; Anderson, L. Desafortunados: um estudo sobre o povo da rua. Petrópolis: Vozes; 1998.

Stoffels, M. G. Os Mendigos na cidade de São Paulo. Rio de Janeiro: Paz e Terra; 1977.

Varanda, W. Do direito a vida à vida como direito - Sobrevivência, intervenções e saúde de adultos destituídos de moradia nas ruas da cidade de São Paulo. São Paulo; 2003. (Dissertação de mestrado da Faculdade de Saúde Pública da USP)

Vieira, MAC, Bezerra EMR, Rosa CMM. População de Rua - Quem é, Como Vive, Como é Vista. $2^{\text {a }}$ ed. São Paulo: Hucitec; 1994. 